\title{
Nucla CFB Demonstration Project
}

Detailed Public Design Report

December 1990

Work Performed Under Contract No.: FC21-89MC25137

For

U.S. Department of Energy

Office of Fossil Energy

Morgantown Energy Technology Center

Morgantown, West Virginia

By

Colorado-Ute Electric Association, Inc.

Montrose, Colorado 


\section{DISCLAIMER}

This report was prepared as an account of work sponsored by an agency of the United States Sovernment. Neither the United States Government nor any agency thereof, nor any of their employees, makes any warranty, express or implied, or assumes any legal liability or responsibility for the accuracy, completeness, or usefulness of any information, apparatus, product, or process disclosed, or represents that its use would not infringe privately owned rights. Reference herein to any specific commercial product, process, or service by trade name, trademark, manufacturer, or otherwise does not necessarily constitute or imply its endorsement, recommendation, or favoring by the United States Government or any agency thereol. The views and minions of authors expressed herein do not necessarily state or reflect those of the United States Government or any agency thereor.

This report has been reproduced directly from the best available copy.

Available to DOE and DOE contractors from the Office of Scientific and Technical Information, P.O. Box 62, Oak Ridge, TN 37831; prices available from (615)576.8401, FTS 626.8401.

Available to the public from the National Technical Information Service, U.S. Department of Commerce, 5285 Port Royal Rd., Springfield, VA 22161. 
$\mathrm{DOE} / \mathrm{MC} / 25137--2999$

DE9 1002081

\title{
Nucla CFB Demonstration Project
}

\author{
Detailed Public Design Report
}

Work Performed Under Contract No.: DE-FC21-89MC25137

For

U.S. Department of Energy

Office of Fossil Energy

Morgantown Energy Technology Center

P.O. Box 880

Morgantown, West Virginia 26507-0880

By
Colorado-Ute Electric Association, Inc.

P.O. Box 1149

Montrose, Colorado 81402

December 1990 
Policy Statement . . . . . . . . . . . . . . . . viii

Acknowledgements . . . . . . . . . . . . . . . . . ix

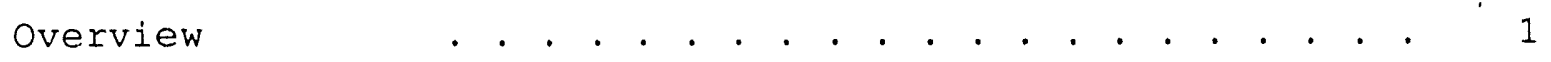

Section I Introduction . . . . . . . . . . . . . . 17

Section II Circulating AFBC Boiler Systems . . . . . . . 45

2.1 Circulating AFBC Boiler .. . . . . . . . 45

2.1.1 Process and Component Summary . . . . . . . 45

2.1.2 Water Circulation System . . . . . . . . . 58

2.1.3 Combustion Chamber Superheater . . . . . 58

2.1.4 Backpass Heat Transfer Surface . . . . . . 59

2.1.5 Sootblowers . . . . . . . . . . . . . 61

2.1.6 Boiler Insulation/Lagging/Casing . . . . 61

2.1.7 Boiler Vents and Drains. . . . . . . . 62

2.2 Coal and Limestone Feed Systems . . . . . . . 63

2.2.1 Circulating AFBC Boiler Coal Feed System . 63

2.2.2 Circulating AFBC Boiler Limestone Feed System 66

2.3 Air and Flue Gas System . . . . . . . . . 67

2.3.1 Draft Eans . . . . . . . . . . . . . 71

2.3.2 Water-Cooled Air Distributor and Windbox . 72

2.3.3 Air Ducts and Gas Flues . . . . . . . . . . 74

2.3.4 Tubular Air Heater . . . . . . . . . . 75

2.3.5 Elaghouses .. . . . . . . . . . . . 79

2.3.5.1 Existing Baghouses 1-3 . . . . . . . . 79

2.3.5.2 New Baghouse 4A . . . . . . . . . . . 79

2.3 .6 Stack . . . . . . . . . . . . . 80

2.4 Solids Separation and Recricle system . . . . . . 81

2.4.1 Hot Cyclones . . . . . . . . . . . . . . . 82

2.4 .2 Loop Seals . . . . . . . . . . . . . . . . 82

2.4.3 Expansion Joints . . . . . . . . . . . . 83

2.4.4 Refractory . . . . . . . . . . . . 83

2.4.5 High-Pressure Blowers . . . . . . . . . 84

2.5 Boiler Startup system . . . . . . . . . . . 84 
2.6 .1

Starting Up

85

2.6 .2

Normal Operation

2.6.2.1 Drum Level/Feedwater Control

87

$\cdot \cdot \cdot \cdot 87$

2.6.2.3 Combustion Control/Load Control . . . 87

2.6 .3

2.6.2.4 Combustion Air Control . . . . . . . . 87

2.6 .4

Master Euel Trip . . . . . . . . . 88

Shut Down... . . . . . . . . . . . 89

Section III Material Handling Systems . . . . . . . . . . 90

3.1 Coal Handling System . . . . . . . . . . . 90

3.2 Limestone Handling System . . . . . . . . . . . 94

3.3 Ash Handling and Disposal Systems . . . . . . . 97

3.3.1 Fly Ash Handling System . . . . . . . . . . 98

3.3.2 Bottom Ash Handling System . . . . . . . 101

Section IV Balance-of-Plant Mechanical Equipment. . . . . 106 and Systems

4.1 Power and Process Piping . . . . . . . . . 106

4.1.1 Main Steam System .. . . . . . . . . 106

4.1.2 Extraction Steam System . . . . . . . . . 107

4.1.2.1 Units 1-3 Extraction Steam . . . . . . 107

4.1.2.2 Unit 4 Extraction Steam . . . . . . . 108

4.1.3 Auxiliary Steam System . . . . . . . . 109

4.1.4 Low Pressure Feedwater System . . . . . . . 111

4.1.5 High Pressure Feedwater System . . . . . . 112

4.2 Plant water Systems . . . . . . . . . . 113

4.2.1 Raw/Service Water System . . . . . . . . . 113

4.2.2 Preboiler Water Treatment System . . . . . 114

4.2.3 Closed Cooling Water System . . . . . . . . 115

4.2.4 Wastewater System . . . . . . . . . . . . . 116

4.2.5 Condensate Storage and Transfer . . . . . . 117

4.2.6 Potable Water System . . . . . . . . . . . 117 
CONTENTS (Continued)

Page No.

4.3 Circulating water System . . . . . . . . . . 118

4.3.1 Units 1-3 Circulating Water System . . . . 118

4.3.2 Unit 4 Circulating water System . . . . . . 119

4.4 Condenser and Accessories . . . . . . . . . . 120

4.5 Chemical Feed Systems . . . . . . . . . . . 121

4.5.1 Feedwater Chemical Feed System . . . . . . 122

4.5.2 Boiler Chemical Feed System . . . . . . . . 122

4.5.3 Cooling Tower Chemical Feed System . . . . 122

4.5.4 Closed Cooling Water Chemical Feed System. 123

4.5.5 Water Sampling and Monitoring Syster . . . 123

4.6 Miscellaneous Mechanical Equipment . . . . . . . 124

4.6.1 HVAC Systems . . . . . . . . . . . . . . . 124

4.6.1.1 New Turbine and Boiler Building HVAC . 125

4.6.1.2 New Control and Logic Rooms HVAC . . . 126

4.6.1.3 New Electrical Room HVAC . . . . . . . 126

4.6.1.4 New Maintenance Shop HVAC . . . . . . 127

4.6.1.5 New Electrical Shop HVAC . . . . . . . 127

4.6.1.6 New Battery Room HVAC . . . . . . . . 127

4.6.1.7 New Variable-Speed Control . . . . . 127

4.6.1.8 New Elevator Machinery Room HVAC . . . 127

4.6.1.9 New Outlying Buildings HVAC . . . . . 127

4.6.1.10 Existing Turbine and Boiler Building HVAC 128

4.6.2 Compressed Air Systems . . . . . . . . . . 128

4.6.3 Cranes and Hoists . . . . . . . . . . . . . 129

4.6.4 Lube Oil Storage and Conditioning . . . . . 129

4.6.5 Fire Protection . . . . . . . . . . . . . . 130

4.6.6 Fuel Gas Supply . . . . . . . . . . . . . 130

Section V Turbine-Generator and Balance-of-Plant . . . . 132

Electrical Equipment and Systems

5.1 Turbine-Generator . . . . . . . . . . . . . . 132

5.1.1 Existing Unit 1-3 Turbine-Generators . . . 132

5.2.2 New Unit 4 Turbine-Generator . . . . . . . 133

5.1.2.1 Turbine Gland Seal System . . . . . . 135

5.1.2.2 Turbine Lube Oil System . . . . . . . 136

5.1.2.3 Generator Seal Oil System . . . . . 137 
CONTENTS (Continued)

Page No.

5.2 Electrical Equipment

5.2.1 Generator and Main Power Transformer System 138

5.2.1.1 Existing Unit $1-3$ Generator and . . . 138

5.2.1.2 New Unit 4 Generator and Step-Up . . . 138

5.3 Auxiliary Power System . . . . . . . . . . . . . 140

5.3.1 Design Load Estimate Surniary . . . . . . . 141

5.3.2 New Station Auxiliary Transformer . . . . . 141

5.3.3 Medium-Voltage System . . . . . . . . . 143

5.3.4 480-Volt System . . . . . . . . . . . . . 143

5.3.5 Emergency Power... . . . . . . . . . 144

5.3.6 Harmonic Considerations . . . . . . . . . . 144

5.4 Uninterruptible and DC Power Supply . . . . . . 144

5.5 Electrical Bulk Materials . . . . . . . . . . 144

Section VI Plant Instrumentation and Controls . . . . . . 146

Equipment and Systems

6.1 Analog Control . . . . . . . . . . . . . 146

6.2 Digital Control . . . . . . . . . . . . . 146

6.3 Alarms and Annunciators . . . . . . . . . . . . 147

6.4 Pneumatic Controls . . . . . . . . . . . . . . 147

6.5 Control Mode . . . . . . . . . . . . . . . . . 147

6.6 Control Drives . . . . . . . . . . . . . . . . . 147

6.7 Displays . . . . . . . . . . . . . . . . . . 147

6.8 Local Control Systems . . . . . . . . . . . . . 148

6.9 System Design Responsibilities . . . . . . . . . 148

6.10 AFBC Boiler Furnace Safety and Fuel . . . . . . 148

6.11 Control Panel/Cabinets . . . . . . . . . . . . . 149

6.12 New Turbine Control System . . . . . . . . . . . 149

6.13 Emission Monitoring System . . . . . . . . . . . 149 


\section{CONTENTS (Continued)}

Page No.

Section VII Special Instrumentation . . . . . . . . . . 151

7.1 Data Acquisition System Computer and Peripherals 151

7.1.1 Operator's Console (OPCON) . . . . . . . 151

7.1.2 DEC VAX 8200 Computer . . . . . . . . . . . 151

7.1.3 DPU11 . . . . . . . . . . . . . . . 151

7.1.4 Gateway . . . . . . . . . . . . . 152

7.2 Special EPRI Test Program Instruments . . . . . 152

7.3 Facilities and Equipment to Support . . . . . 153

7.3.1 Operations Center and Computer Rooms . . . 153

7.3.2 Chemical Laboratory Facilities . . . . . . 154 and Equipment

7.4 Ash Weighing System . . . . . . . . . . . . . 154

7.4.1 Fly Ash Weighing . . . . . . . . . . 155

7.4.2 Bottom Ash Weighing . . . . . . . . . . 156

7.4.3 Coal "As Fired" Sampling . . . . . . . . . 157

7.4.4 Limestone Sampling .. . . . . . . . . 158

7.4.5 Asil Transport Sampling . . . . . . . . 158

7.5 Gas Analyzers . . . . . . . . . . . . . . . . 158

7.5.1 E/FGAS Analyzer . . . . . . . . . . . . . 158

7.5.2 FGAS Probes . . . . . . . . . . . . . 160 
CONTENTS (Continued)

Illustrations

Eiqure

Page No.

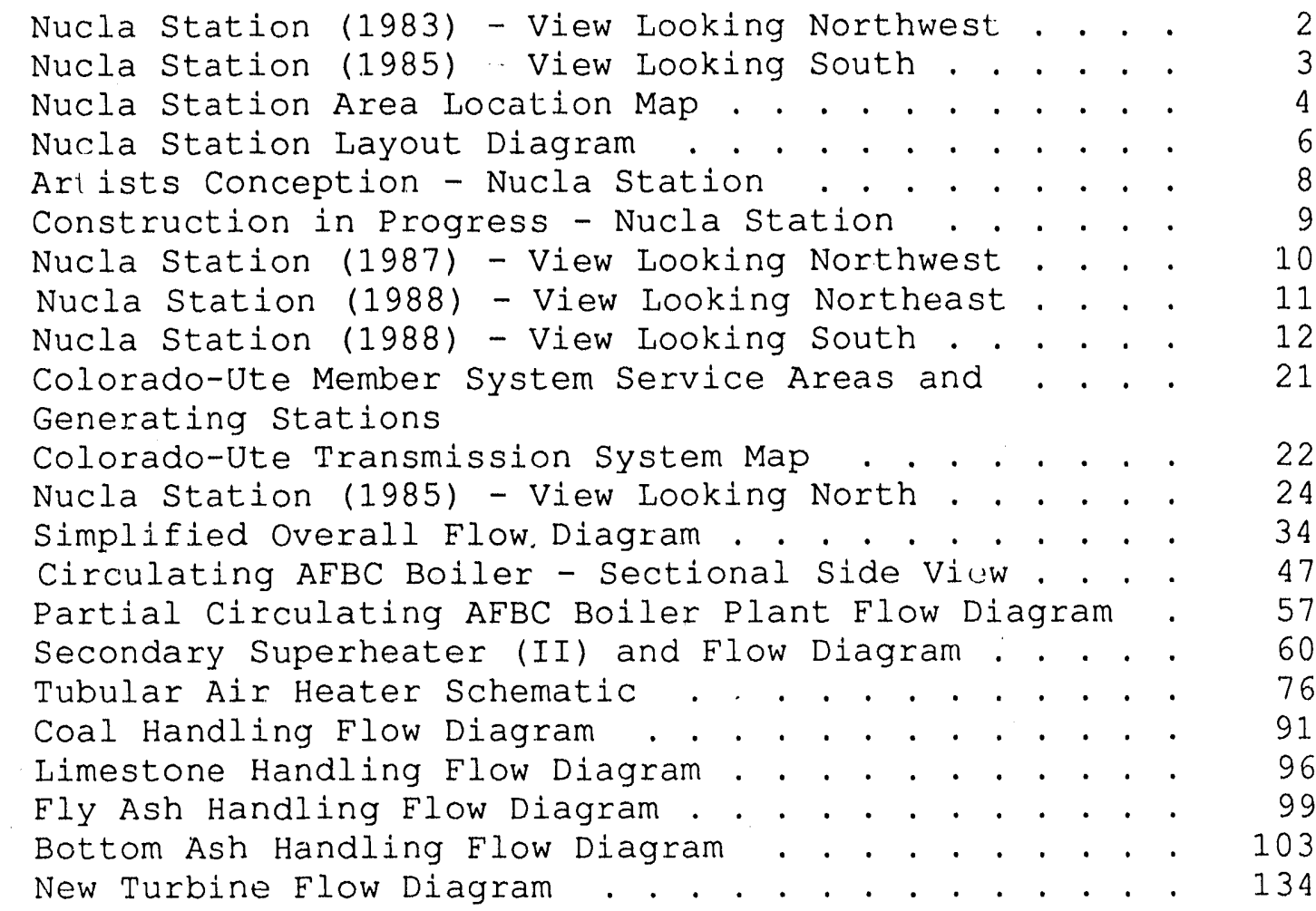

Tables

Table

Page No.

1 Colorado-Ute Electric Association Total Year-End .

Power Requirements and Resources Nucla Coal Analysis. . . . . . . . . . . . . . 30

3 Nicla Ash Analysis . . . . . . . . . . . . . . . . . 31

4 Summary of Equipment Specifications . . . . . . . . . 35

5 Estimated Capital Costs Summary . . . . . . . . . . 38

6 Projected First-Year Operating Costs . . . . . . . . 40

7 Circulating AFBC Boiler Performance Summary . . . . . 46

8 Plant Site Environmental Design Parameters . . . . . 52

9 Coal Fuel Analysis . . . . . . . . . . . . . . . . . 53

10 Ash Mineral Analysis . . . . . . . . . . . . . . 54

11 Limestone Analysis . . . . . . . . . . . . . . . . . 55

12 Water Analysis . . . . . . . . . . . . . . . . 56 
Table

Page No.

13 Coal Feed System Design Data . . . . . . . . . . . 65

14 Limestone Feed System Design Data . . . . . . . . . . 68

15 Air and Gas System Design Performance Data . . . . . 70

16 Draft Fan Performance Summaries . . . . . . . . . . . 73

17 Air Heater Performance Summary . . . . . . . . . . . 78

18 Tabulation of Plant Auxiliary Loads . . . . . . . . . 142

Appendix A. Plant Equipment and Data List . . . . . . . A1-A82

Appendix B. Non-Proprietary Process and Instrumentation . B1-B? Drawing Index... . . . . . . . . . 36 Exhibits

Appendix C. Proprietary Process and Instrumentation . . . C1 Drawing Index... . . . . . . . . . 8 Exhibits

Appendix D. Technical Advisory Group . . . . . . . . . D1-D4

\section{Revision Record}

Original

Project Public Design Report "Draft" submitted July 1, 1990

Revision 1

Detailed Public Design Report "Camera-Ready

Draft" submitted

December 7, 1990 
PARTICIPANT'S

PROJECT PUBLIC DESIGN REPORT

\section{Policy statement}

The Project Participant does hereby approve this Project Public Design Report and further designates it as the official document the Project Performer shall use and submit to DOE in accordance with the Cooperative Agreement requirements of the selected Project in the County of Montrose, State of Colorado.

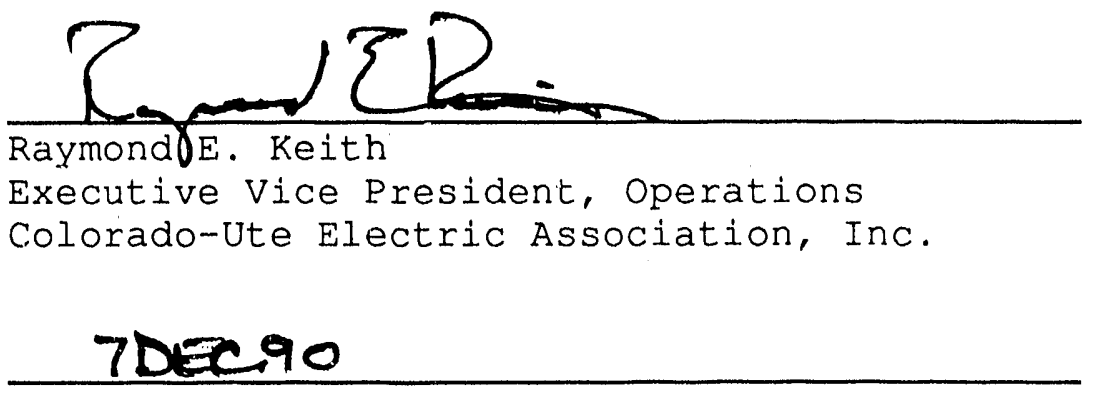
Date 


\section{Acknowledgements}

President Woodrow Wilson said "I'll use all the brains I have and all the brains I can borrow". This quotation exemplifies the approach used by Colorado-Ute to the Nucla Atmospheric, Circulating Fluidized Bed Combustion Demonstration Project.

The Electric Power Research Institute (EPRI) is gratefully recognized as the principal organization which conducted the testing activities, compiled resulting information and contributed several million dollars to the project. Their electric industry spunsorship and cooperation also provided staffing for the test program and the Detailed Test Plan used to guide the project direction.

The U. S. Department of Energy (DOE), Clean Coal Technology division was another major project contributor. Under Cooperative Agreement (DE-FC21-89MC25137), the 19.9 million dollar contribution provided a significar.t project milestone. The Morgantown Energy Technology Center administration of the Agreement likewise contributed to the project results.

The Rural Electric Administration ( $R E A$ ) and Cooperative Einance Corporation (CEC) project concurrence and financial support was without doubt an integral part to the project's evolution.

The many organizations which comprise the Technical Advisory Group (TAG Committee), their time and monetary support were likewise invaluable to the project.

The major and minor manufacturers, suppliers and contractors which brought together the talents of so many people to assemble the. project.

The financial institutions which supported Colorado-Ute with a project of this nature also must not be forgotten.

Last but hardiy least, Colorado-ute acknowledges its 14 member cooperatives for proceeding with the project. These 1.4 showed the true spirit of pioneers in technology advancement.

The diverse list of participants above begins to unveil the inherent complexity of such a project which attempts to push back the frontier of knowledge. Information, what is learned, right or wrong, good or bad is the essence of scientific endeavor to improve our world and all that live withir it.

This report combines, correlates, refines and presents the information and data with permission which was initially documented in the EPRI series CS-5831. It satisfies the Colorado-Ute requirements under DOE instrument No. DE-EC21-89MC25137. 


\section{OVERVIEW}

Colorado-Ute Electric Association. Incorporated (CUEA) began a study to evaluate options for upgrading and extending the life of its Nucla power station in 1982 (see Figures 1 and 2). Located in southwestern Colorado, near the town of Nucla, this station was commissioned in 1959 with a local bituminous coal as its design fuel for the three identical stoker-fired units, each rated at $12.6 \mathrm{MW}$ (see Figure 3). Poor station efficiency, high fuel costs, and spiraling boiler maintenance costs forced the Nucla station into a low priority in the CUEA dispatch order as early as 1981.

Among the options Colorado-Ute (CU) considered was the possibility of becoming a host utility to demonstrate Atmospheric Fluidized Bed Combustion (AFBC) technology. Th low environmental effects and attractive economics of a circulating AFBC led to Coloracio-Ute's decision to proceed with the design and construction of a demonstration project in 1984 at the Nucla facility.

The company determined that the new circulating AFBC boiler technology would:

- Increase plant capacity from $36 \mathrm{MW}$ to $110 \mathrm{MW}$ for an investment of approximately $\$ 840 / \mathrm{KW}$;

- Improve the station heat rate by approximately $15 \%$;

- Reduce fuel costs (approximately 30\%) by burning the local area, lower quality coal;

- Reduce emissions to the point where anticipated New Source Performance Standards for $\mathrm{SO}_{2}$ and $\mathrm{NO}_{x}$ could be met; and

- Extend the plant operating life by approximately 30 years.

Many factors went into Colorado-Ute's decision to proceed with the demonstration project. Among these were two Electric Power Research Institute (EPRI)-sponsored boiler design studies conducted by Combustion Engineering/Lurgi and Pyropower Corporation in late 1983. Both manufacturers submitted firm proposals within six months. In evaluating these, Colorado-ute:

- Reviewed the design, backup data, and experience base cited by the manufacturers;

- Identified areas of possible technical risk;

- Identified design studies and test programs that could mitigate these risks; 


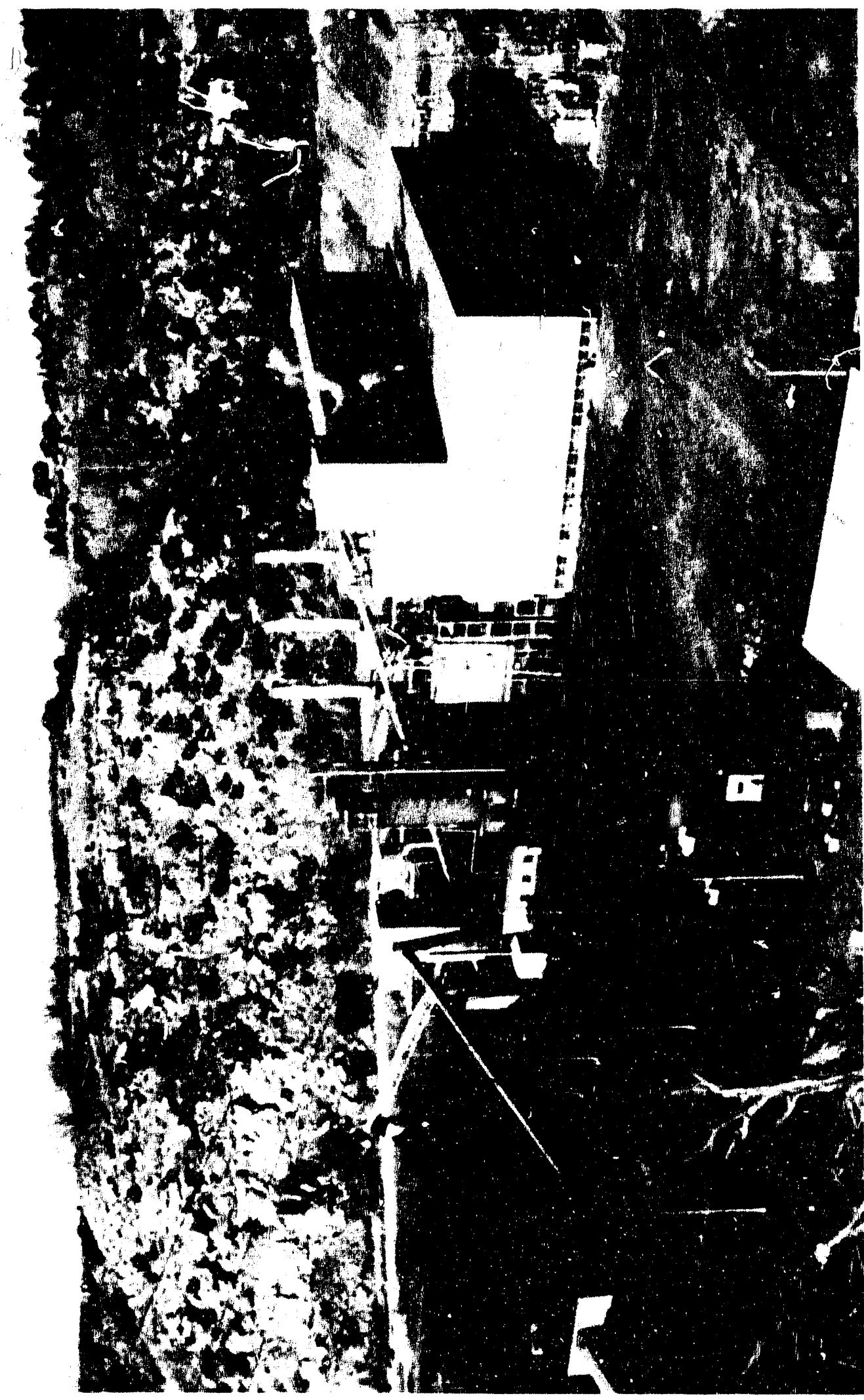




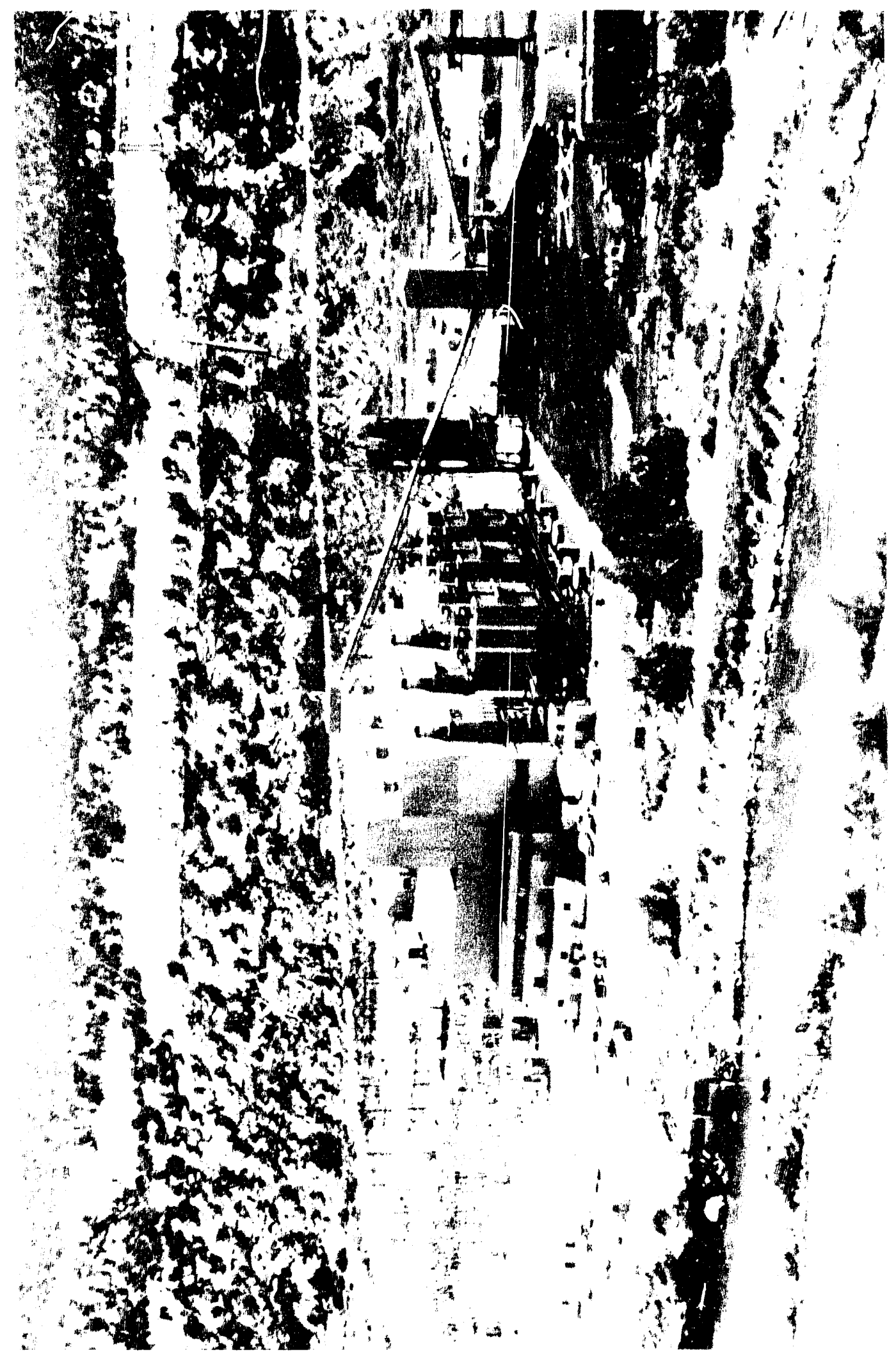



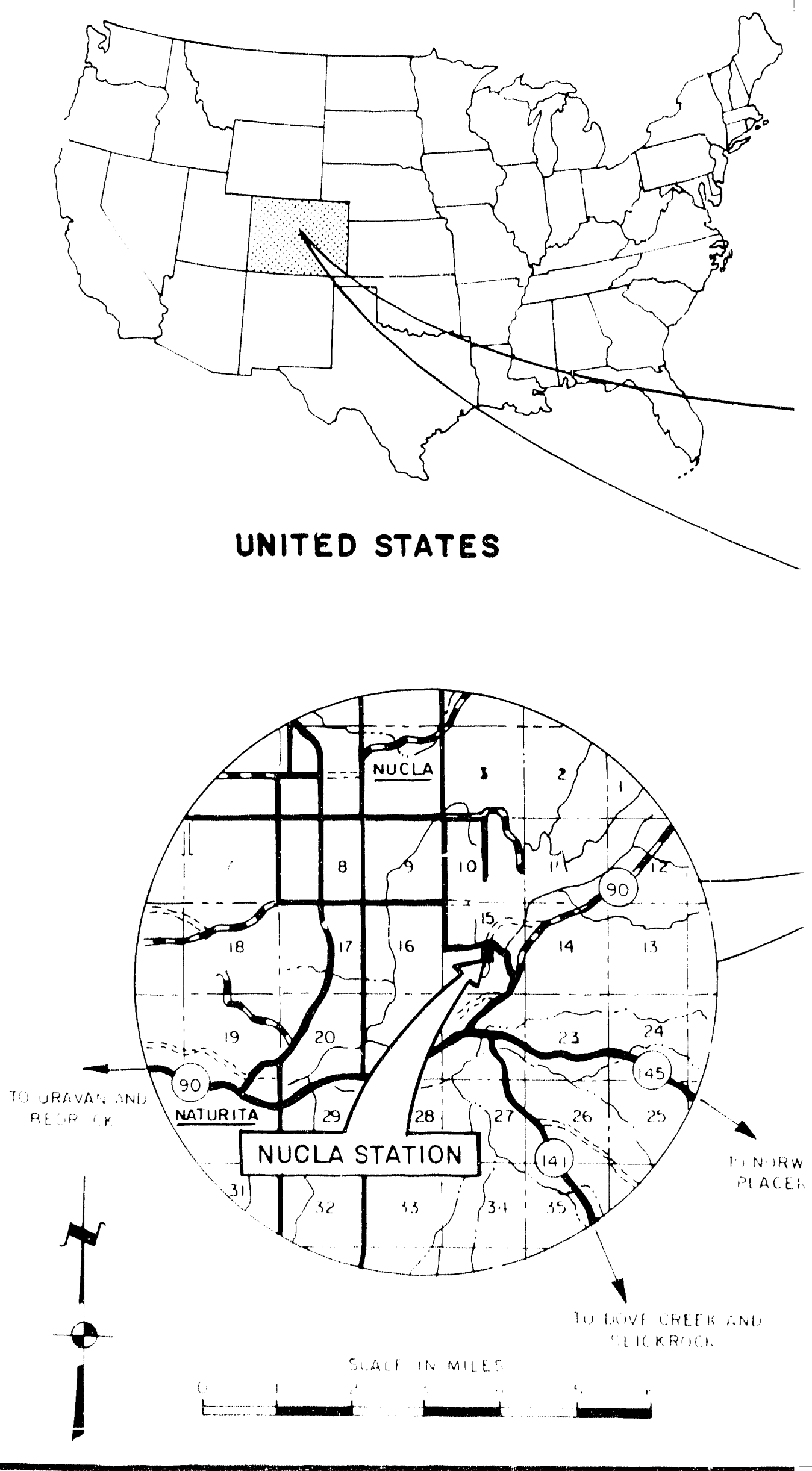


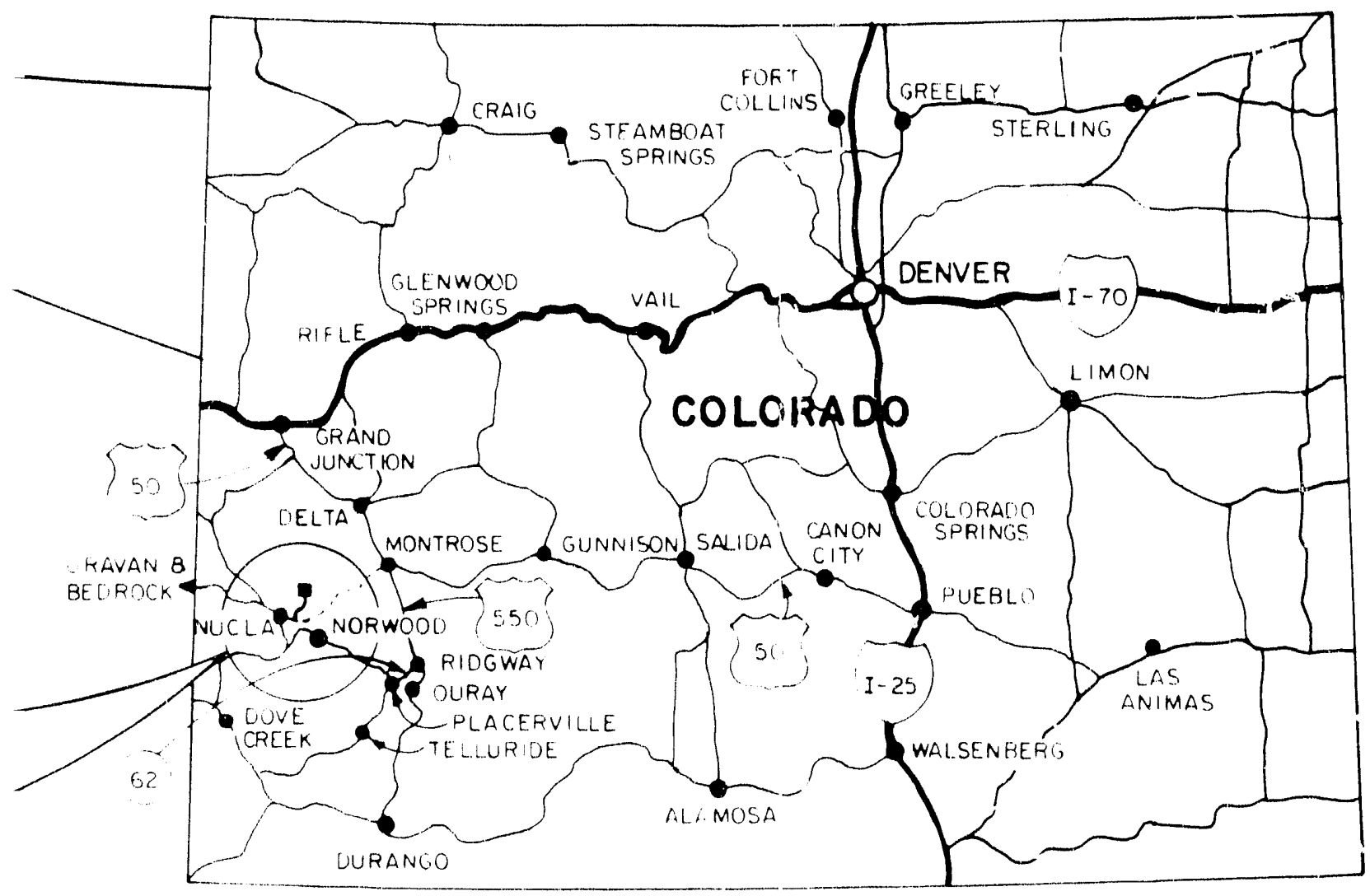

SCALE IN MILES

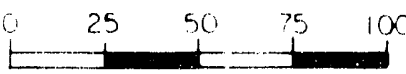

WOC AIN

RVI:LE

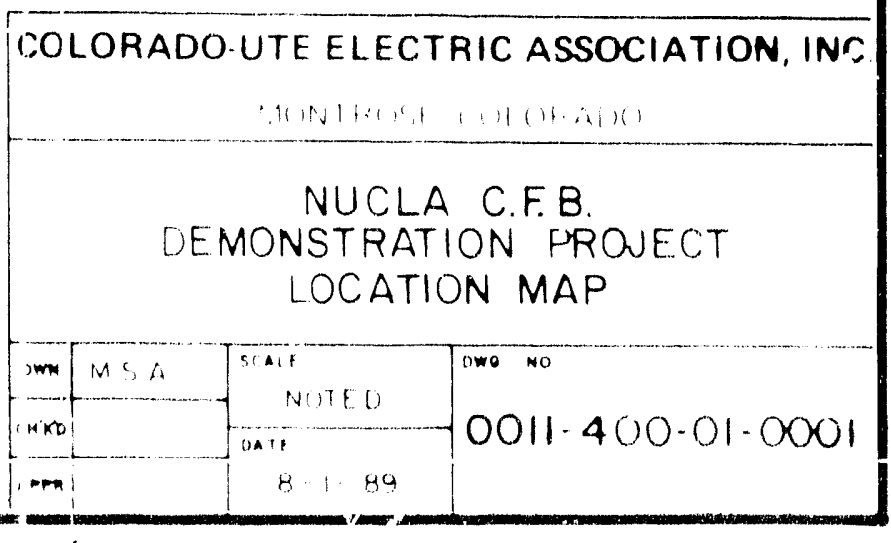

FIGURE 3

NUCLA STATION

AREA MAP
NUCLA C.F.B

STRATION

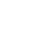


- Developed fallback designs in the event i hat soloctod aroigns did not: perform as predicted;

- Assessed the risks to the ut jlity: and

- Developed a strategy for hegot at ing with the oguipmont suppliers.

colondo-ute judged Pyropower's proposal had a low combinen aptal and life-cycle cost, and thenfore awated it the luata stat ion circulating AFBC boilor contract.

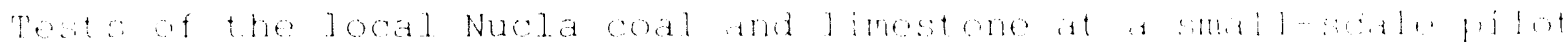

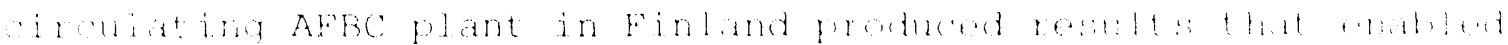

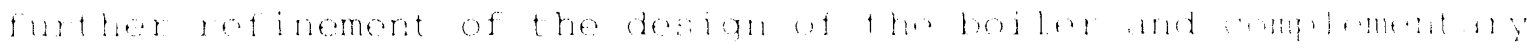
anditisy aluiment.

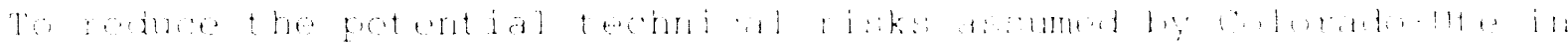

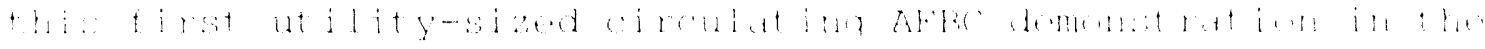

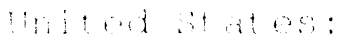

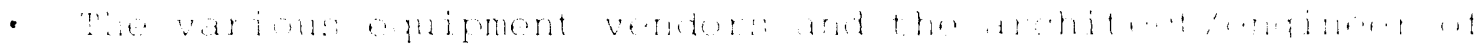

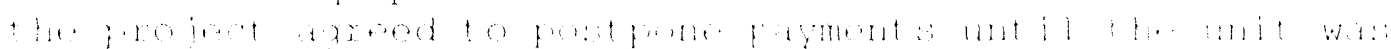

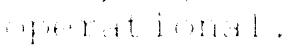

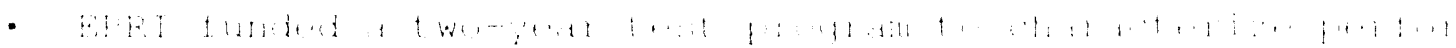

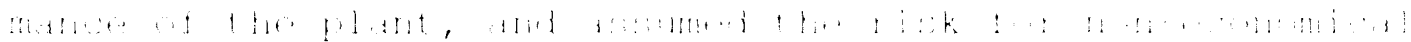

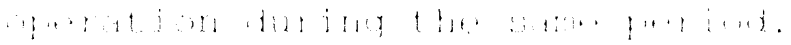
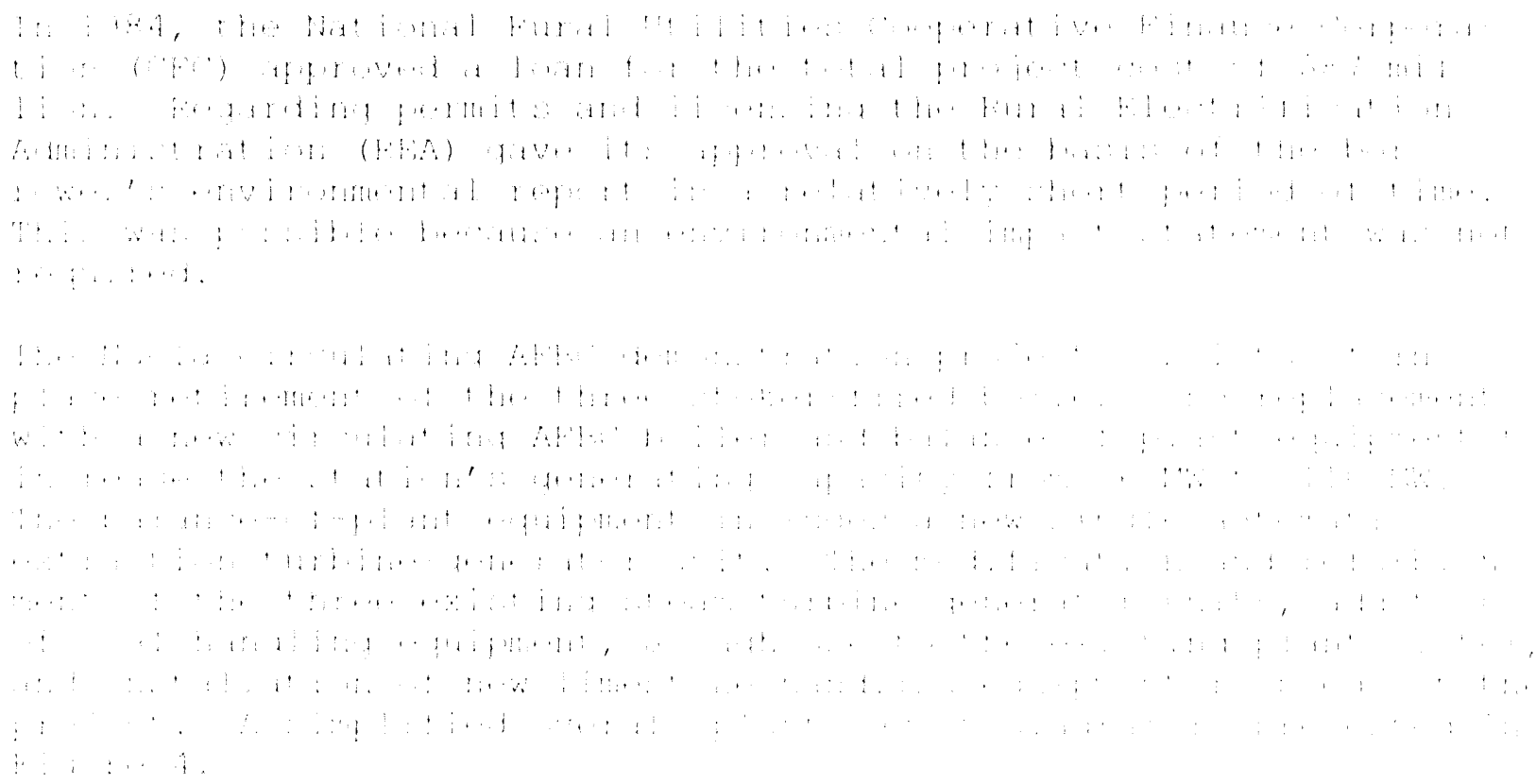


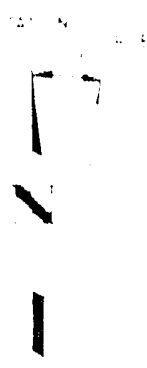

$G$ 

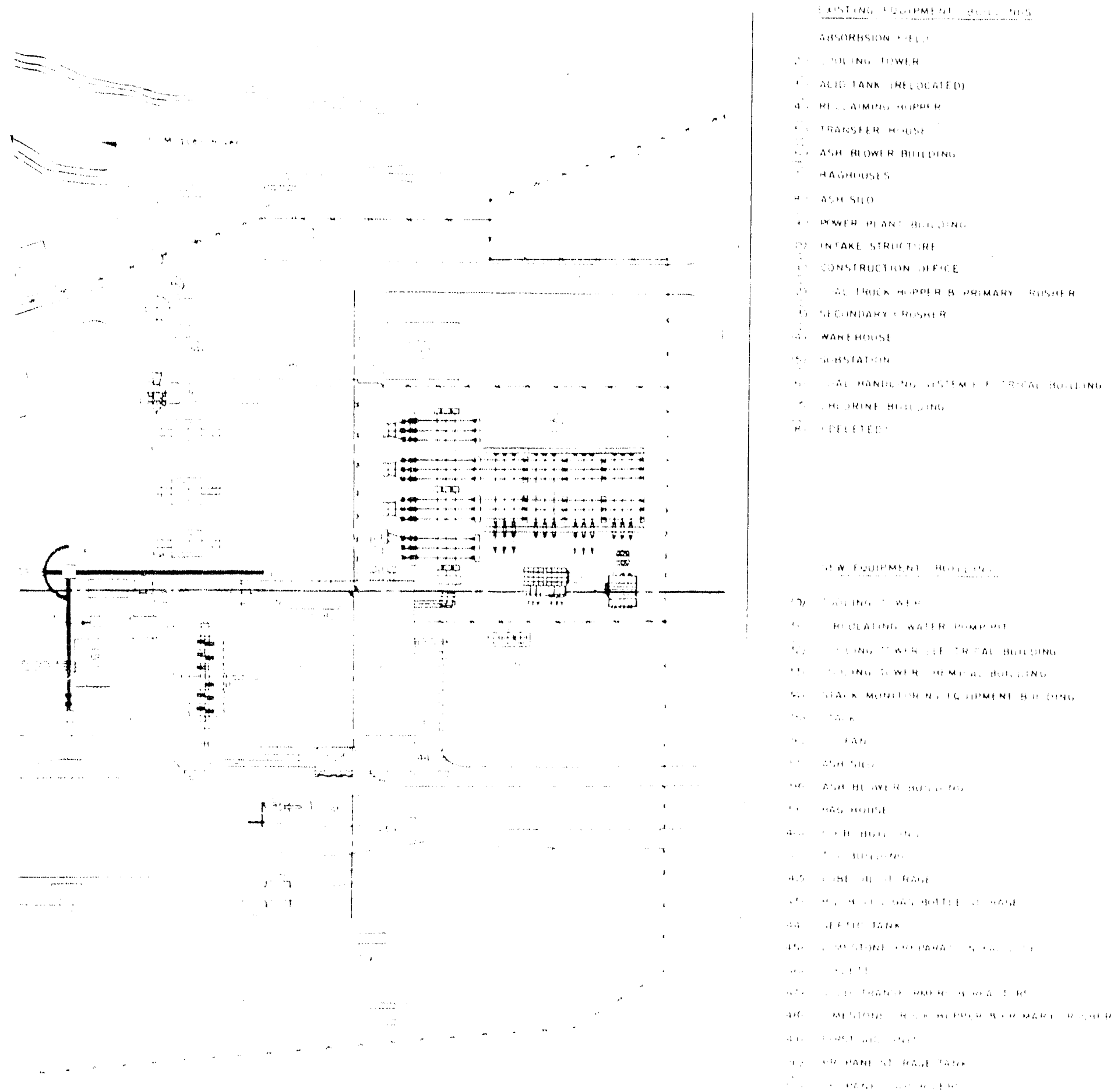

FIGURE 4 
Photographs of the artist's conception, construction and completed Nucla Station facility are presented in Figures 5, 6, 7, 8 and 9.

The new circu ating $A F B C$ boiler is rated at $420,000 \mathrm{~kg} / \mathrm{hr}(925,000$ $\mathrm{lb} / \mathrm{hr})$ capacity with superheat steam conditions of $106 \mathrm{~kg} / \mathrm{cm}^{2}$ and $540^{\circ} \mathrm{C}\left(1510 \mathrm{psig}\right.$ and $\left.1005^{\circ} \mathrm{F}\right)$. The circulating $A F B C$ boiler is approximately four times larger than existing industrial circulating fluidized-bed units. This represents a significant upward sizing step in the use of a new technology that promises lower capital costs and a cleaner, more environmentally acceptable method to burn coal for central station power plants.

Twin combustion chambers and hot cyclones are featured in this circulating AFBC boiler design. The twin combustion chambers were utilized by the boiler marufacturer, Pyropower Corporation, to provide the required amount of waterwall heat transfer area and reduce the sizing scale-up factor. The Nucla boiler combustion chamber and hot cyclone scale-up factors were limited to 2 to 1 (as compared to the boiler manufacturer's largest operating circulating $A F B C$ boiler at design time), thus the use of the twin-system concept. Some other features of the new Nucla circulating AFBC boiler are:

1. Boiler pressure parts, including water-coo? $\triangleq d$ primary air distributor, combustion chambers and convection section of membrane wall construction, superheater sections (including radiant sections located in the top of the combustion chambers), economizer, steam drum and downcomers, desuperheaters (attemperators), and boiler interconnecting piping.

2. Variable-speed controlled induced-draft fan.

3. Combustion air supply, including a variable-speed controlled primary-air fan and a variable-speed controlled secondary-air fan.

4. Bed ash letdown and cooling equipment, including fluidbed cooler/classifiers, rotary airlock valves, watercooled screw conveyors, and an ash cooling fan.

5. Coal-feed equipment, including gravimetric feeders and rotary airlock valves.

6. Limestone-feed equipment, including gravimetric feeders, rotary airlock valves, and pneumatic injection.

7. Bed-recycle equipment, including refractory-lined hot cyclones and loop seals, and high-pressure blowers. 


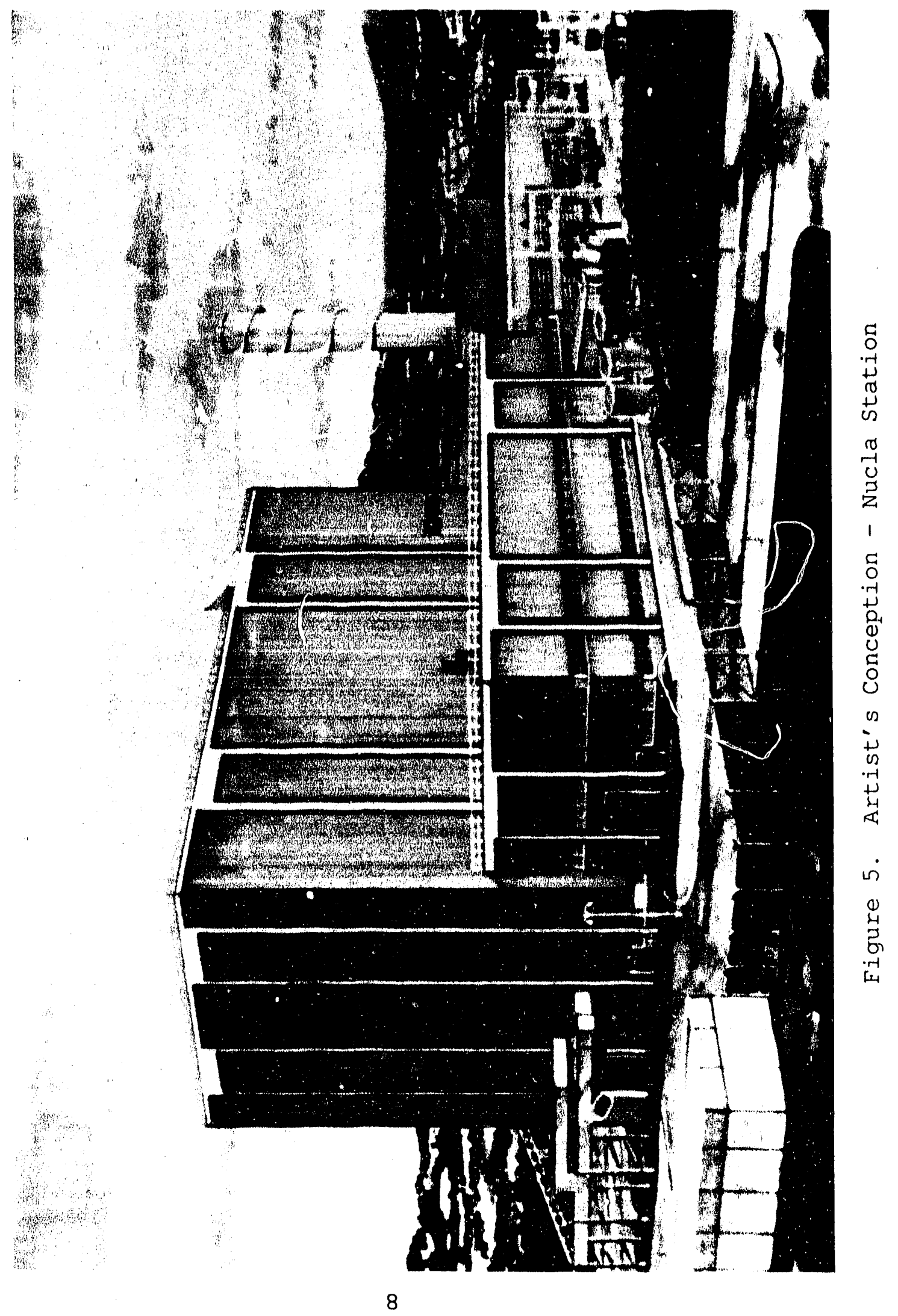




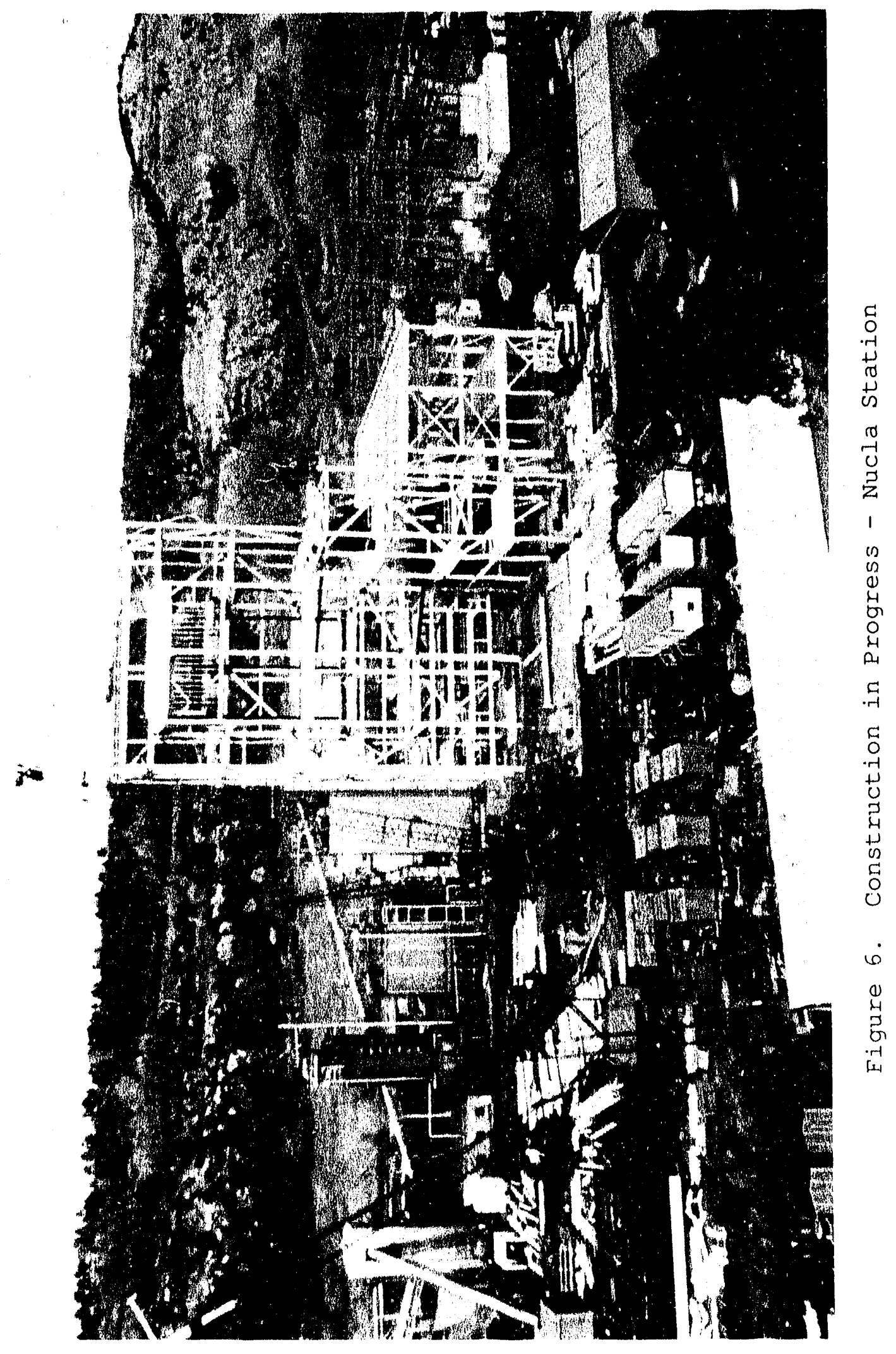




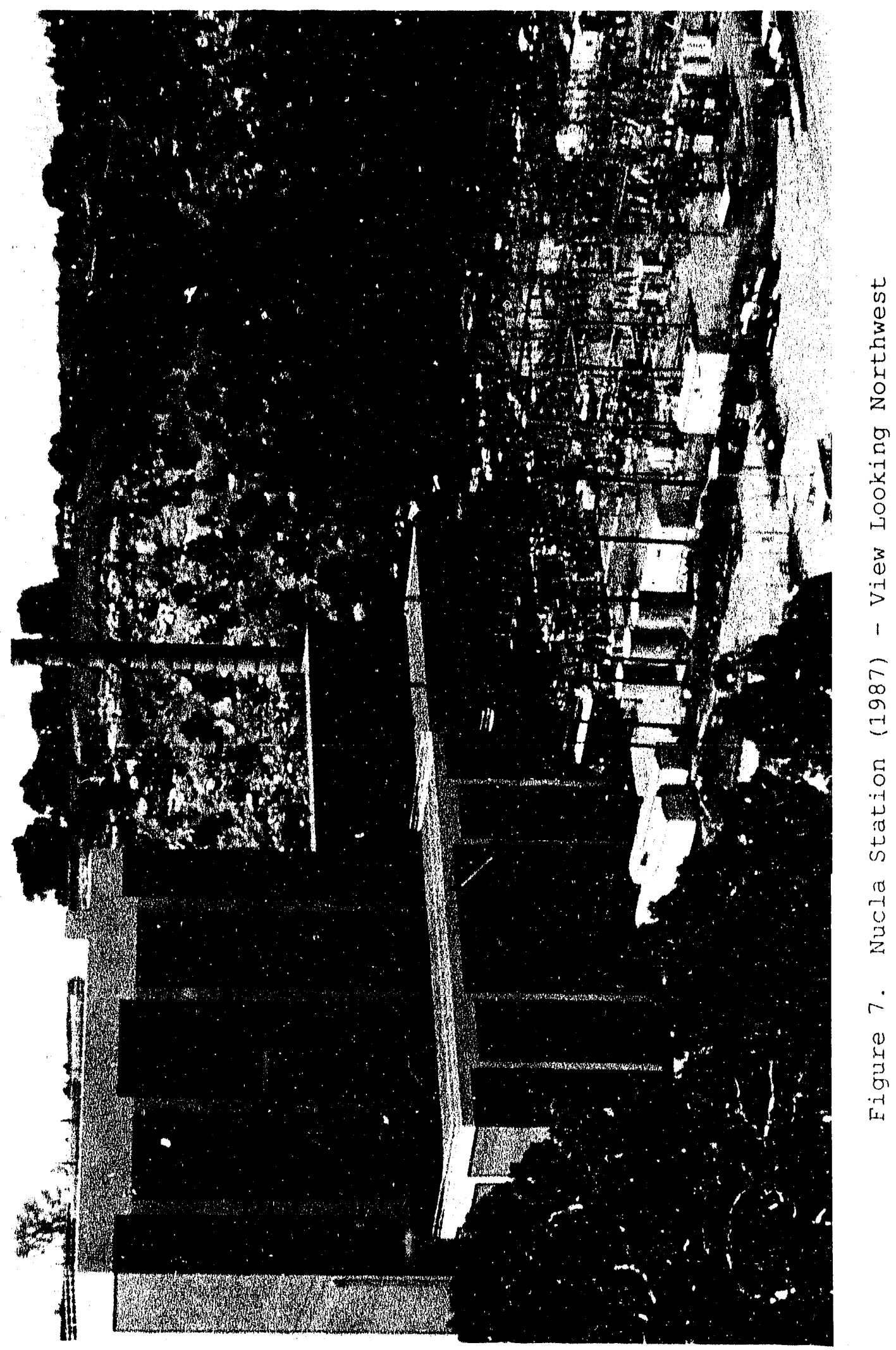




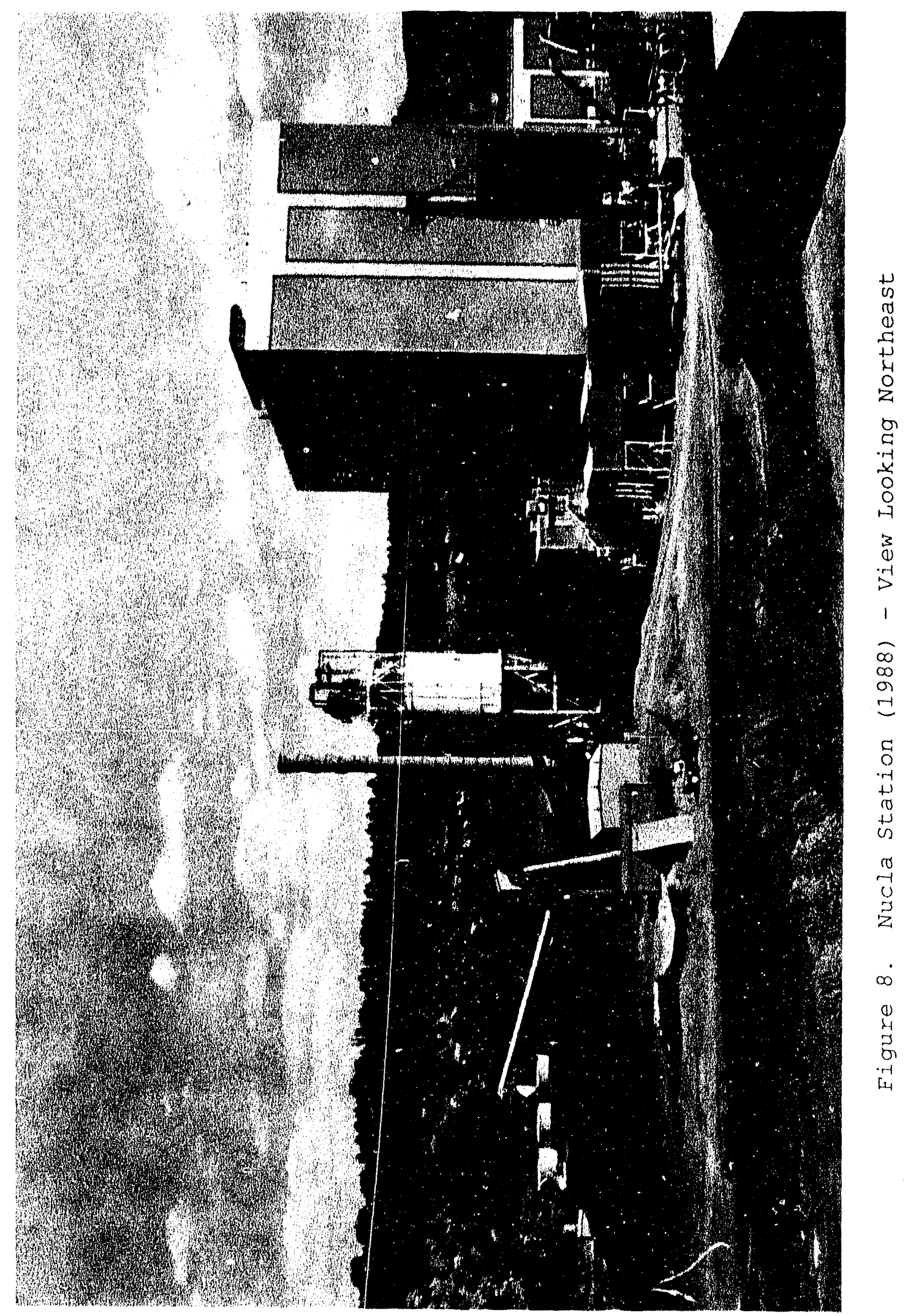




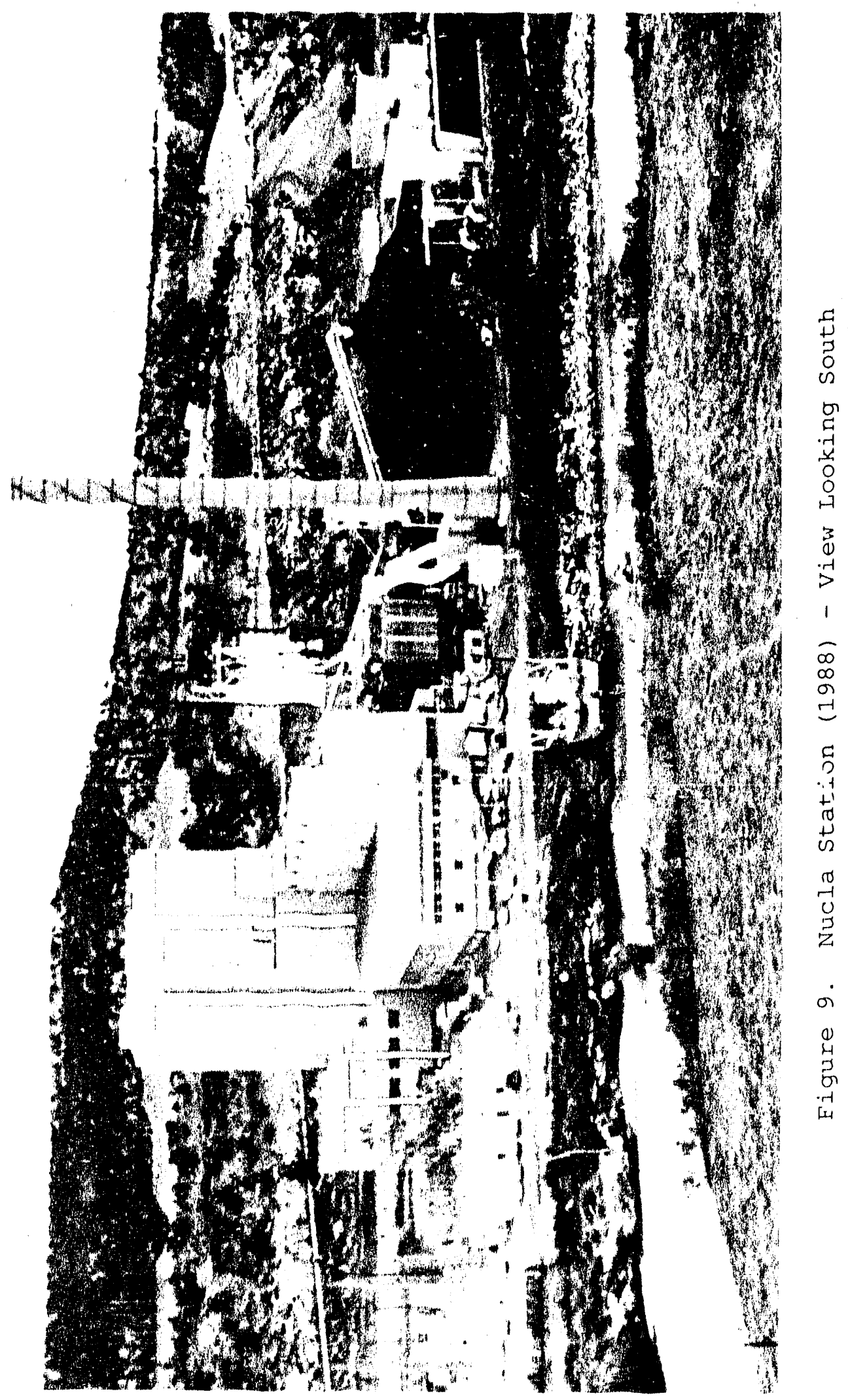


8. Startup and duct burners.

9. Tubular air heater.

10. Miscellaneous koiler items, including insulation, lagging, casing, sootblowers, and boiler vent and drain equipment.

Additional boiler plant equipment and systems that support the new circulating AFBC boiler are:

11. New limestone receiving, storage, preparation, and conveying equipment.

12. A new steel stack.

13. A refurbished plant coal-handling system and new coalhandling equipment to prepare and deliver coal to the circulating $A F B C$ boiler coal silos.

14. Three refurbished baghouses and a new baghouse, which in parallel remove particulate matter from the circulating $A F B C$ boiler flue gas stream.

15. Refurbished, modified, and new bottom ash and fly ash handling and storage equipment.

The balance of both existing and new plant equipment and systems include:

16. The original three 12.6-MW turbine-generators now run from a new 74-MW single-automatic-extraction turbine-generator.

17. Main steam, extra tion steam (including a controlled extraction from the new turbine supplying steam to the existing turbines), and auxiliary steam piping systems.

18. New high-pressure feedwater cycle equipment including boiler-feed pumps and high-pressure feedwater heaters.

19. A refurbished and a new plant circulating water cooling system, each consisting of a mechanical-draft evaporativecooling tower and circulating water pumps.

20. Refurbished and new low-pressure feedwater cycle equipment for each turbine-generator unit inciading condensers, condensate hotwell pumps, low-pressure feedwater heaters, and deaerators.

21. Refurbished and new fiat water systeme including a new boiler makeup demineralizer system. 
22. Refurbished and new miscellaneous mechanical equipment including heating, ventilating and air cunditioning (FVAC) equipment, air compressors, fire protection system, and a new propane system.

23. Plant instruments and controls including a new plant distributed control system.

24. Plant electrical equipment and systems.

Because of the potential offered by use and commercialization of circulating AEBC technology to the electric fower industry, Colorado-Ute Electric Association, Inc., and the Electric Power Research Institute (EPRI) initiated a program to study the Nucla circulating $A F B C$ boiler and its operating characteristics. This project is being conducted in conjunction with two other EPRIsponsored AEBC demonstration projects: Northern States Power Company's bubbling 130-MW Black Dog demonstration and Tennessee Valley Aulhority's bubbiing 160-MW Shawnee demonstration. For the Nucia demonstration, EPRI installed special hardware for the program including instrumentation, data acquisition and processing equipment and facilities necessary to conduct a two-year test program.

The U. S. Department of Energy likewise participated in the project through the Clean Coal Technology Program - Phase I. The Cooperative Agreement, DE-FC21-89MC25137 was administered by DOE'S Morgantown Energy Technology Center located in Morgantown, West Virginia.

Site construction was started in the spring of 1985 and startup took place during the summer of 1987 . A chronology of the principal project events is presented below:

\section{Date}

Summer 1982

Spring-Fall 1982

Eebruary 1983
Activity

Colorado-Ute begins considering options that would allow its Nucla Station to continue operating.

ERRI discusses with colorado-ute the possibility of its being a host utility to demonstrate AEBC technology.

Colorado-Ute submits a detailed proposal to EPRI for a 100-MW bubbling AEBC demonstration unit at its Nucla Station. 
Date

Spring 1983

Summer 1983

November 1983

Winter 1983-1984

April 4, 1984

June 5,1984

Winter 1983-1984

through

Summer 1984

August 1984
Activity

EPRI awards the main contract for AFBC demonstration to TVA; however, Colorado-Ute continues to investigate merits of an $A F B C$ retrofit for Nicla based on attractive economics and the need $+j$ "do something with Nucla" to prevent its closure. Colorado-Ute begins investigating the merits of circulating versus bubbling AFBC technology.

Colorado-Ute decides to continue with the Nucla project, with or without outside participation.

EPRI funds a two-task circulating AFBC boiler study. One task is Nucla site specific for a 100-MW unit; the other task is for a hypothetical 500-MW unit. Boiler studies are awarded to both Combustion Engineering/Lurgi and Pyropower with the stipulation that they be prepared to bid a circulating AFBC boiler lump sum in the spring of 1984 .

Colorado-Ute receives results of the boiler studies and, with technical assistance from EPRI, prepares circulating $A F B C$ boiler specifications.

Colorado-Ute issues a circulating AFBC boiler Request for Proposal to Combustion Engineering/Lurgi and Pyropower.

Both vendors submit boiler proposals to Colorado-Ute.

Colorado-Ute initiates permit, licensing and financing efforts. Rural Electrification Administration (REA) gives preliminary approval for the project based on borrowers' environmental report, without environmental impact statement. Loan application for total project cost approved by National Rural Utilities Cooperative Finance Corporation (CFC).

Colorado-Ute Board of Directors gives approval to proceed with design and construction of the Nucla circulating AFBC demonstration project. 


\section{Date}

September 14, 1984

November 1984

April 1985

May 1985

August 1985

December 1985

October 1986

March 1987

May 1987

June 1987

April 1988

June 1.988

July 1988 -

June 1990

August 1990

October 1990
Circulating AFBC boiler contract is awarded to Pyropower.

Site preparation contractor begins grading and installing circulating water lines.

General contractor mobilization at site.

Concrete work starts three weeks early.

Circulating AFBC boiler steel erection starts.

Steam drum is raised.

Circulating AFBC boiler is hydrostatically tested.

Circulating AFBC boiler boilout.

Steam to turbine and initial synchronization.

First coal firing.

Boiler Acceptance testing.

U. S. Department of Energy Cooperative Agreement.

EPRI test program.

DOE Extension award.

DOE/CUEA test program continuation. 
Section 1. Introduction

This report documents Colorado-Ute Electric Association's Nucla Circulating Atmospheric Fluidized-Bed Combustion (AFBC) ciemonstration project. It describes the plant equipment and system design for the first U.S. utility-size circulating AFEC boiler and its support systems. Included are equipment and system descriptions, design/background information and appendices with an equipment list and selected information plus process flow and instrumentation drawings (P\&IDS).

The purpose of this report is to share the information gathered during the Nucla circulating $A F B C$ demonstration project and present: it so that the general public can evaluate the technical feasibility and cost effectiveness of replacing pulverized or stoker-fired boiler units with circulating fluidized-bed boiler units.

In 1982, Colorado-Ute Electric Association began a two-year study to develop an alternate project for life extension of its outmoded Nucla station in an effort to keep it open to help meet projected nominal load growth in the late 1980s. The company abandoned plans to develop a large new coal-fired generating station and focused on smaller, lower-cost, and shorter duration projects.

While considfring future operating plans for the Nucla station, Colorado-Ute necame interested in circulating $A F B C$ as a method of burning coal. The benefits of $A F B C$ are low capital costs, reduced air pollution, and the ability to burn different fuels, especially low-grade coals which are abundant in and around the Nucla area.

After reviewing various alternatives and the risks associated with demonstrating the new technology, Colorado-Ute elected to proceed with construction of a 110-MW demonstration circulating AFBC boiler to extend the life and upgrade the capacity of the Nucla station.

\section{TECHNOLOGY BASE}

The evolution of the AFBC technology is broad in scope and international in character. Sixty years ago, pulverized coal combustion was introduced into the electric utility industry for fuel conservation. Environmental issues forced major improvements on the thenapplied stoker furnace designs. During the late 1930 s and early 1940s, Germany developed and commercialized fluidized-bed processing for its growing coal gasification and metal-refining indusiries. The development and use of Eluidized-bed processing accelerated after World War II, particularly in the United States where it was applied to the production of high-octane gasoline from catalytic cracking of heavy oils. From the late $1950 \mathrm{~s}$ to the early 1960s, Great Britain's National Coal Board encouraged the development of $A F B C$ as an improved way of burning coal and meeting environmental 
concerns. The principal motivation for European interest in AFBC at that time was to obtain flexibility in burning locally available and diverse fuels, but in many cases those of low-grade quality.

In contrast, the motivation in the United States was to meet the stringent new regulations imposed by the Environmental Protection Agency (EPA). The federal government, first through the EPA and thereafter through the Department of Energy (DOE), was responsible for many of the initial efforts to develop fluidized-bed technology ir this country. The first U.S. utility AFBC unit was built at the Rivesville Station of the Monongehela Power Company in West Virginia. Built in the early 1970s, this unit operated from December 1976 to 1981. Tt burned coal and had a $136,078-\mathrm{kg} / \mathrm{hr}(300,000$ $\mathrm{lb} / \mathrm{hr}$ ) steam-generating capacity (approximately $30 \mathrm{MW}$ ). The unit was scaled from a 0.5-MW test rig at Alexandria, Virgiria. The DOE support culminated in the construction and operation of three other industrial-scale demonstration units:

- A 45,400 kg/hr $(100,000 \mathrm{lb} / \mathrm{hr})$ unit at Georgetown University, Washington, D.C.

- A $22,700 \mathrm{~kg} / \mathrm{hr}(50,000 \mathrm{lb} / \mathrm{hr})$ unit at the Great Lakes Naval Training Center, Illinois; and

- A $10,442 \mathrm{~kg} / \mathrm{hr}(23,000 \mathrm{lb} / \mathrm{hr})$ anthracite coal-burning unit in Shamokin, Pennsylvania.

Each unit is of a different prototype design; together they have accumulated several years' worth of valuable performance data.

In 1977, with encouragement from several interested utility members, the Electric Power Research Institute (EPRI) built a 2-MW ( $6 \mathrm{ft} \times 6$ ft) pilot plant at the Babcock \& Wilcox (B\&W) research and development center in Alliance, Ohio. This EPRI/B\&W facility provided data that enabled the Tennessee Valley Authority (TVA), B\&W and EPRI to design, build and operate a 20-MW plant at the Shawnee Station near Paducah, Kentucky in 1982. This 20-MW pilot plant was designed and instrumented to:

- Simulate utility power plant conditions;

- Allow testing of different mechanjcal systems; and

- Provide data for designing and operating utility-scale units of 200 to $500 \mathrm{MW}$.

Since July 1982, the TVA 20-MW pilot plant has accumulated over 19,000 hours of coal-firing operation and has confirmed such AFBC features as good combustion efficiency, low level of emissions, and fuel flexibility. 
Past experience with facilities in the United States and abroad has shown that $A F B C$ systems do in fact achieve in-situ emissions control and improved fuel flexibility without sacrificing desirable attributes of operation and maintenance; unlike stoker-fired boilers. Using the experience gained from these facilities, EPRI with a number of electric utilities embarked on a program to demonstrate and commercialize AFBC technology. Three utility-sized units are included in the program:

- Norchern States Power Company's conversion of an existing 100MW pulverized coal unit (Black Dog \#2) to a 125-MW bubbling AFBC unit with an overbed feed system;

- TVA's new 160-MW bubbling AFBC boiler with underbed feed at its Shawnee steam plant near Paducah, Kentucky (the unit will provide steam to the existing turbine and balance-of-plant of Urit \#10); and

- Colorado-Ute's 110-MW circulating AFBC boiler for repowering its Nucla generation station.

These three projects are complementary in terms of the scope of work, time frames, equipment design, fuel fired, and locations. They will provide the electric ut lity industry with data to evaluate future potential of additional AFBC projects. Completion of these projects will demonstrate:

- Operability of the specific designs;

- Reliability of critical power plant components;

- Unique features of AFBC technology such as emission control, fuel flexibility, and good combustion efficiency; and

- Economics of AFBC technology.

COLORADO-UTE ELECTRIC ASSOCIATION, INC.

Colorado-Ute Electric Association, Inc., is a generation and transmission Rural Electrification Administration (REA) cooperative with approximately 750 employees and headquartered in Montrose, Colorado. Colorado-Ute is the operator for generating resources with an aggregate net capacity of $1,757 \mathrm{MW}$, including the existing 36-MW Nucla Station. Colorado-Ute owns $874 \mathrm{MW}$ of the 1,757 MW it operates.

The compaly is owned by its 14 -member system. Together, these systems serve more than half the land area of the state of Colorado, principally the sparsely populated western, southern and central 
portions of the state, and small portions of Utah and wyoming. A map of Colo ado-Ute's member system service area is presented in Figure 10. The member systems are:

Delta-Montrose Electric Association

Empire Electric Association

Grand Valley Rural Power Lines

Gunnison County Electric Association

Holy Cross Electric Association

Intermountain Rural Electric Association

ta Plata Electric Association

Sangre de Cristo Electric Association

San Isabel Electric Association

San Luis Valley Rural Electric Cooperative

San Miguel Power Association

Southeast Colorado Power Association

White River Electric Association

Yampa Valley Electric Association

Colorado-Ute ope ztes a transmission system which is part of the integrated trarsmission grid serving Colorado and neighboring states. The company has interconnections with other utilities, including western Area Power Administration (WAPA) and Public Service Company of Colorado. Colorado-Ute provides electric service to members through its own transmission system and through a variety of wheeling and displacement arrangements (see Figure 11).

The operation of Colorado-Ute's generating units is controlled through the Colorado-Ute dispatch center in Montrose, although WAPA controls over-all system operations in the area.

\section{NUCLA STATION}

Colorado-Ute owns and operates the Nucla power generation station which is located near the town of Nucla at an elevation of 5,600 feet above mean sea level, in southwestern Colorado. The Nucla Station, originally commissioned in 1959, consisted of three 12.5MW coal stoker-fired units. Turbine inlet steam conditions were 42 $\mathrm{kg} / \mathrm{cm}^{2}(600 \mathrm{psig}), 440^{\circ} \mathrm{C}\left(825^{\circ} \mathrm{F}\right)$. Full-load station heat rate was approximately $14.8 \times 10^{6} \mathrm{Joules} / \mathrm{kWh}(14,000 \mathrm{Btu} / \mathrm{kWh})$. The coal was locally mined and laid in shallow beds. Selective mining was employed to ensure delivered contract coal at 6,495 Calories/kg $(11,700 \mathrm{Btu} / \mathrm{lb})$, which is a higher heating value than normal mine runs. Fuel cost had increased to $\$ 29.48 / \mathrm{M}$ ton $\left(\$ 1.39 / 10^{6}\right.$ Btu) in 1983 dollars during the early $1980 \mathrm{~s}$.

Fabric filter particulate control devices (baghouses) and a new crossflow tower cooling system were retrofitted to the station in 1973. After construction, Colorado-Ute participated with EPRI in testing the new fabric filters. These fabric filters were the first 


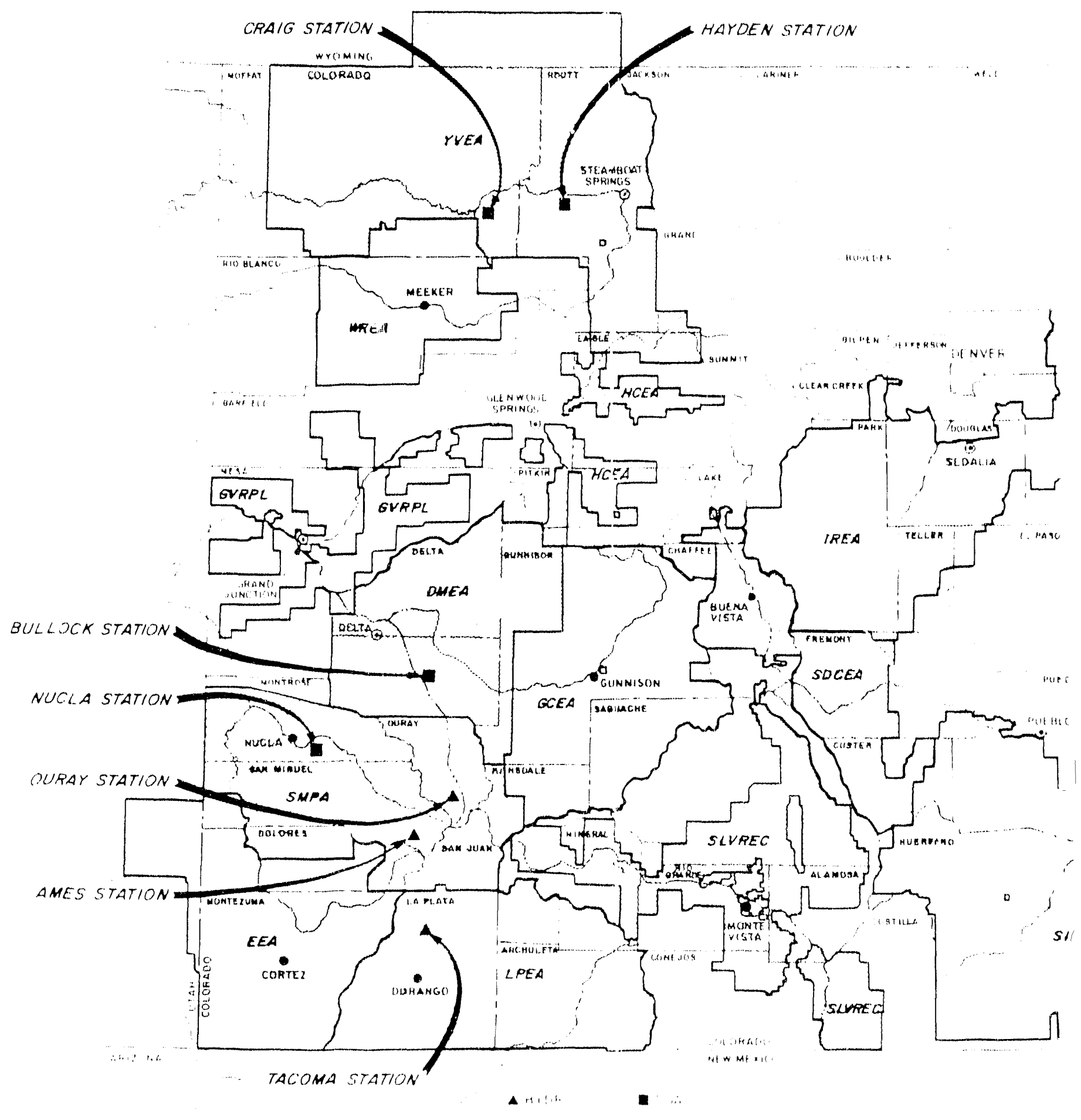

FIGURE 10

COLORADO-UTE MEMBER SYSTEM SERVICE AREAS AND G: 

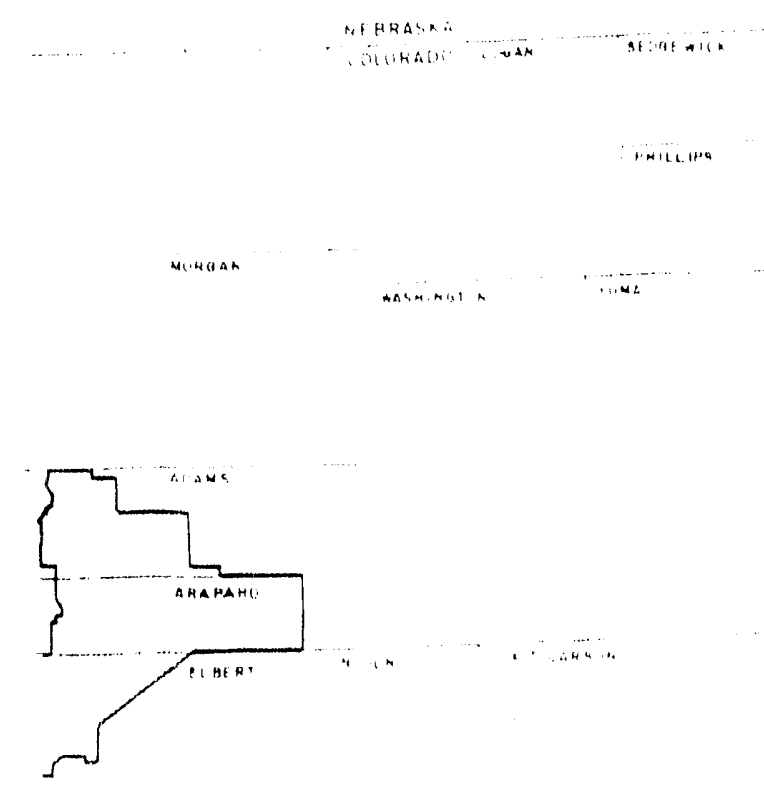

pas

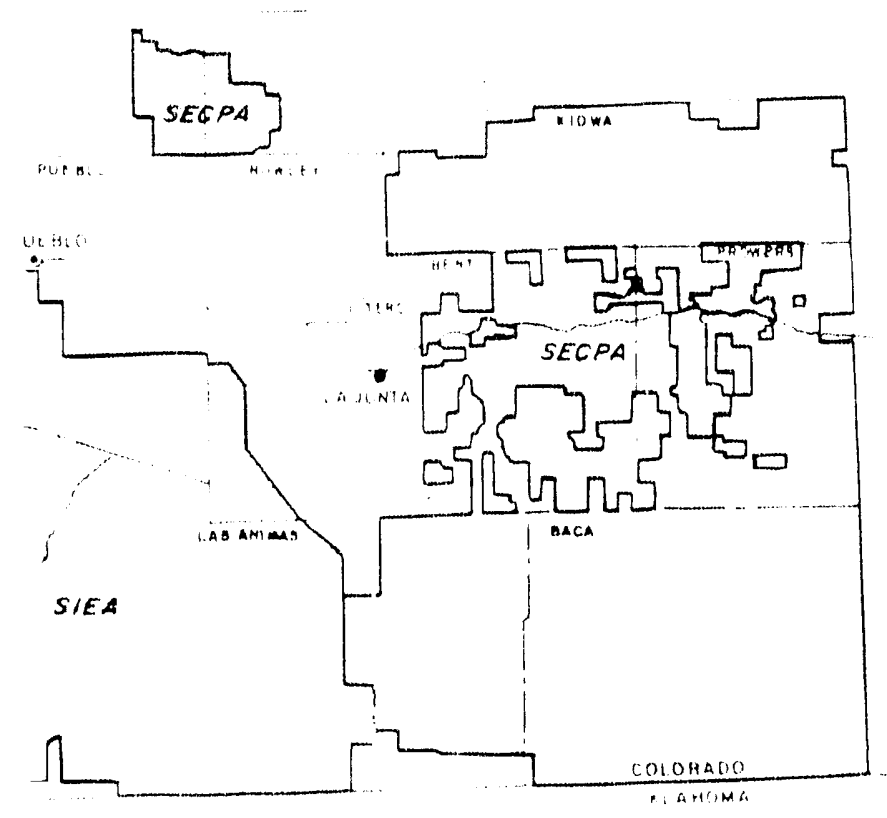

GENERATING STATIONS 


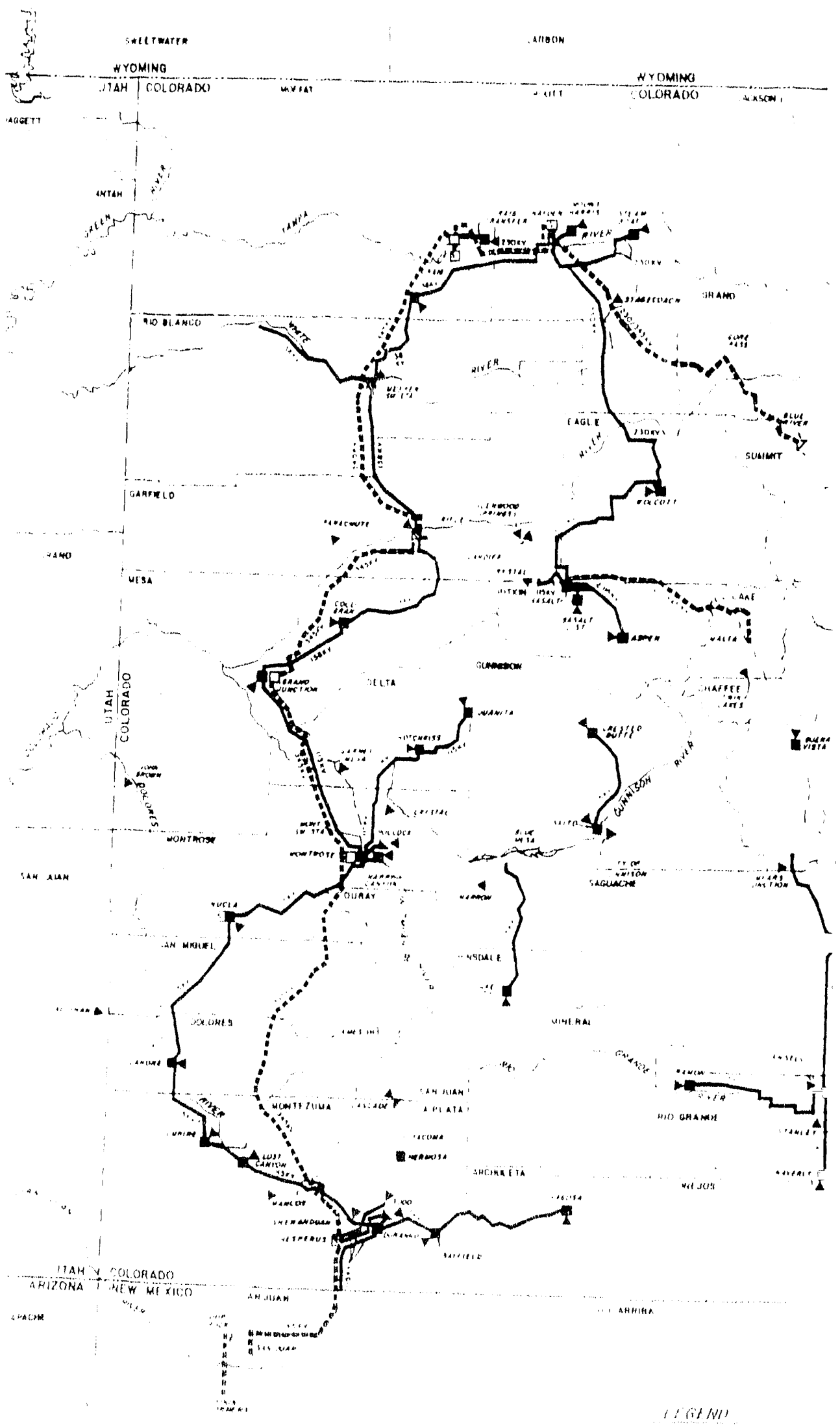




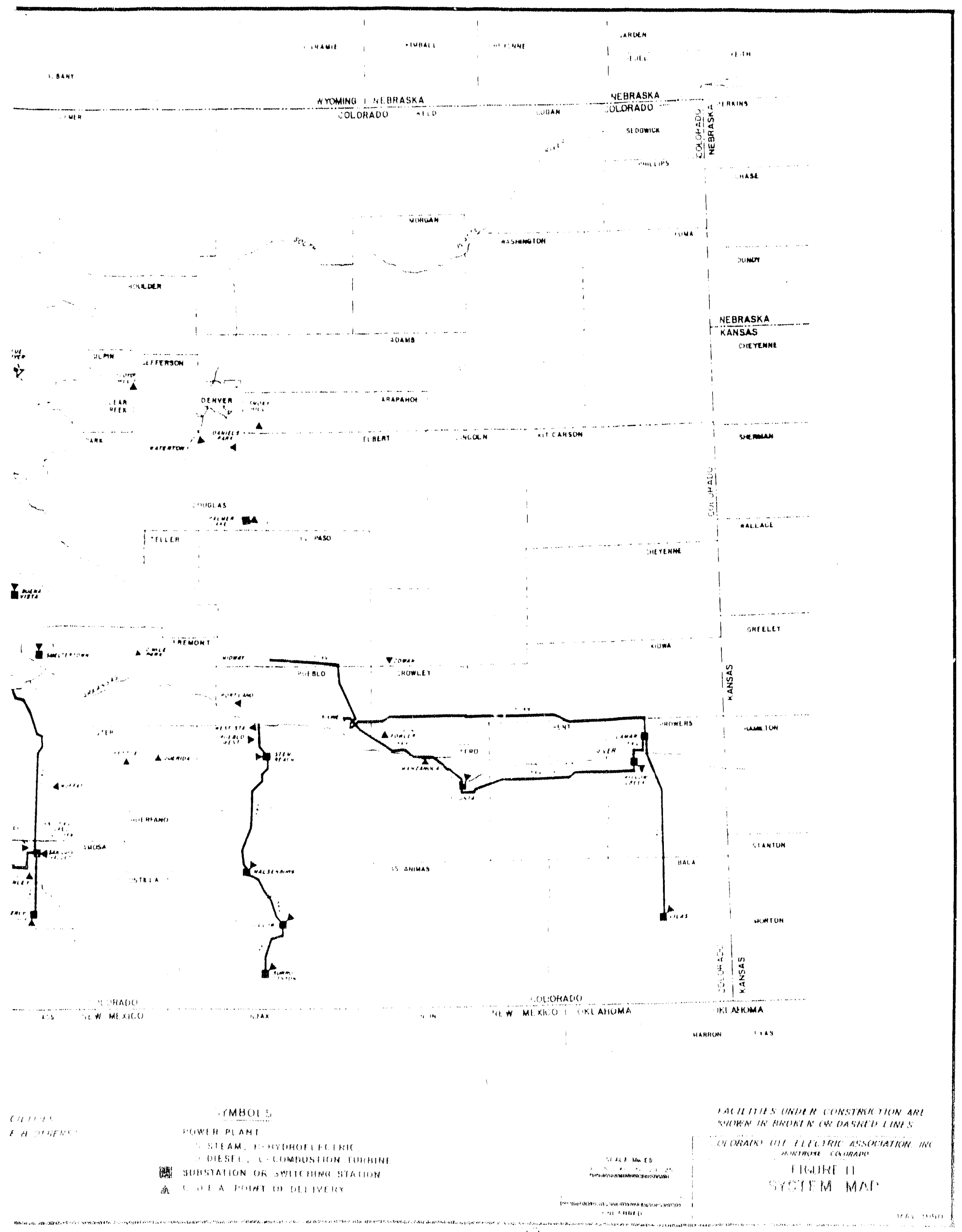


Installed by the electric power industry ard successfully demonstrated the technology in the early 1970 s.

A photograph of the Nucla Station is presented in Figure 12. This photograph was taken after site preparation work for the circulating AEBC demonstration project had begun and before general contractor mobilization. It shows the area immediately to the south of the existing plant cleared for the new circulating AFBC boiler.

In 1982, the plant was nearing the end of its useful life. The disadvantages of poor station efflciency, relatively high fuel costs, and increasingly higher boiler maintenance costs had forced the plant into a low position on the dispatching order. This resulted in a decreased annual coal burn with, consequently, negative effects on mining efficiency and coal costs from the local mine. In fact, for the most part, the station was being operated only duriny the winter peak season to burn the contracted minimum amount of coal and the coal. contract was due to expire in 1984.

Colorado-Ute considered several alternatives to both extending the life of the Nucla station and meeting projected system load growths before committing to the Nucla circulating AFBC demonstration project. Colorado-Ute's 1984 load growth projections are presented in Table 1.

The management of Colorado-Ute strongly desired to keep the Nucla facility open. The small local community had been severely affected by the downturn in the local uranium and coal mining plus forestry products industries. Closure of the Nucla facility would have cost the economically deprived area an additional 50 jobs. ColoradoUte's management felt a strong sense of civic responsibility to help the local economy by keeping the Nucla Station open.

\section{ALTERNATIVE SITES CONSIDERED}

Colorado-Ute has existing coal-fired generating sites near Montrose, Hayden and Craig, Colorado (see figure 10). Bullock Station, located in Montrose, Colorado, is an old coal-fired steam-electric station consisting of two 6-MW units nearing retirement. It was not chosen for conversion to fluidized-bed combustion because there is no nearby coal supply, the transmission system would require modifications to accommodate a 110-MW unit, the existing equipment would not allow easy modification to install the larger unit, and the plant site is actually too small to accommodate such a large project.

Hayden Station is a coal-fired steam electric generating station, located approximately five miles east of Hayden, Colorado. It contains two units with net capabilities of $184 \mathrm{MW}$ and $262 \mathrm{MW}$, 


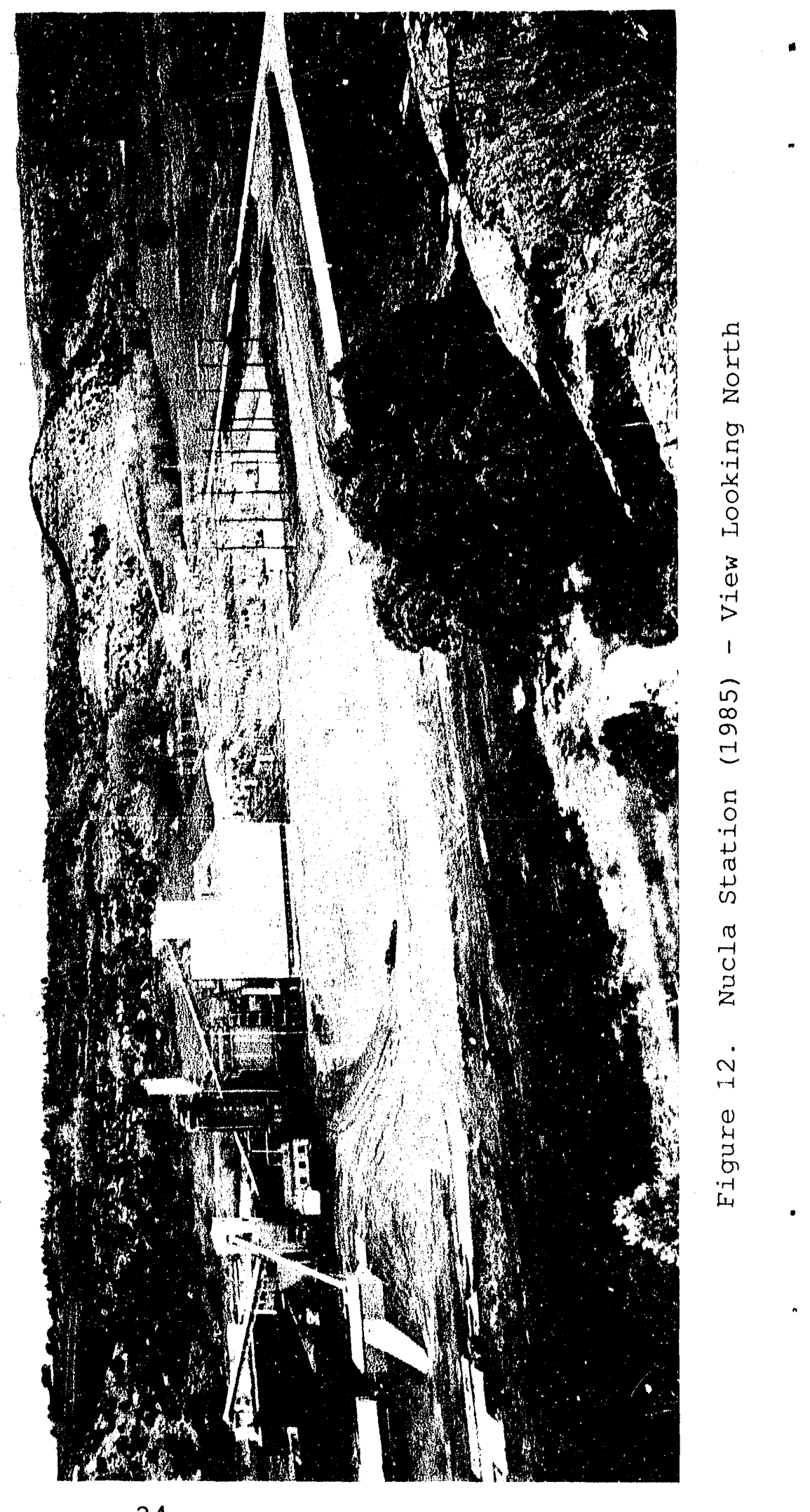




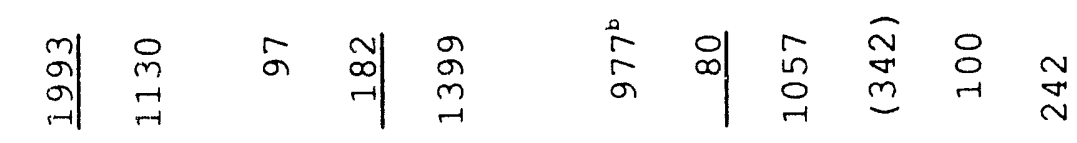

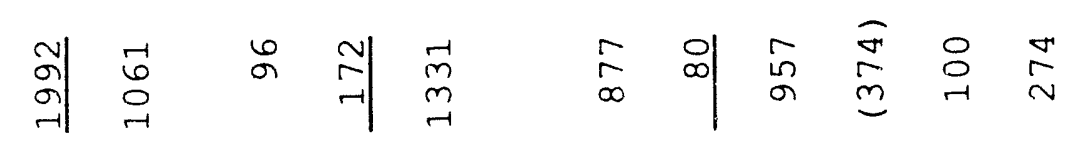

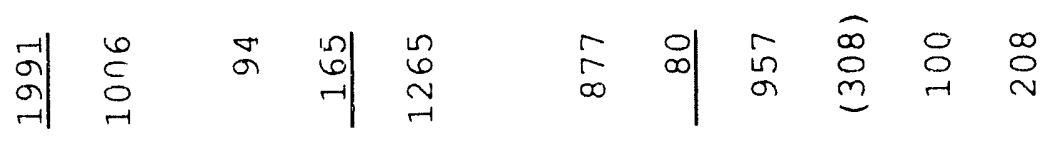

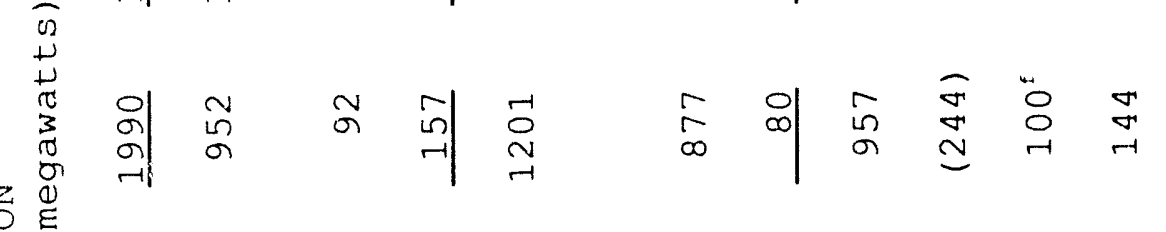

s.

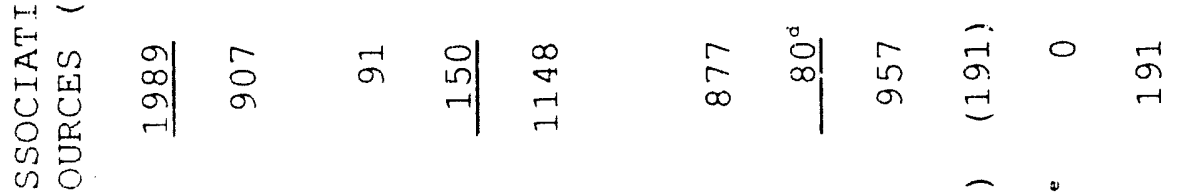

und

占是

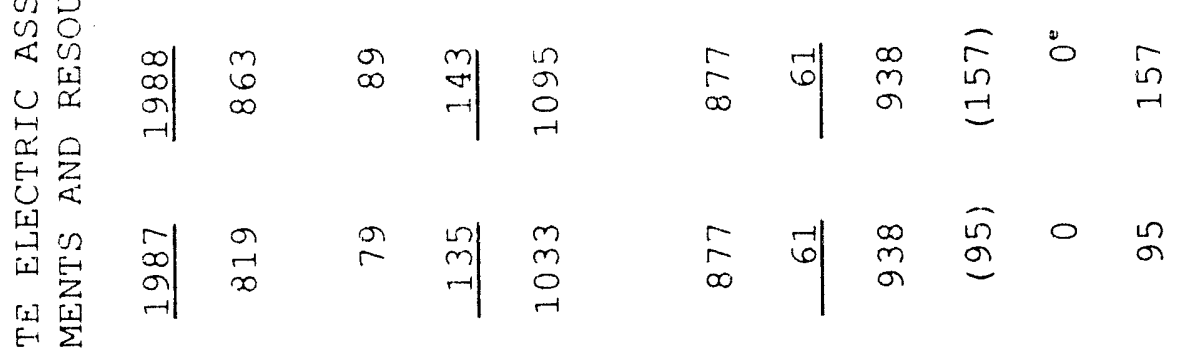

1

窟是

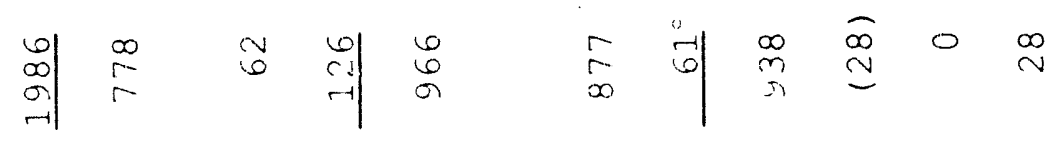

垈

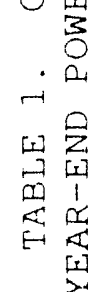

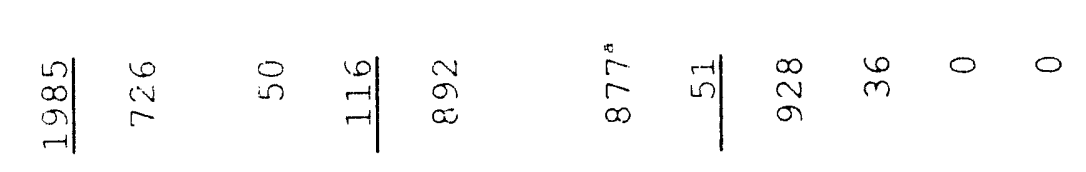

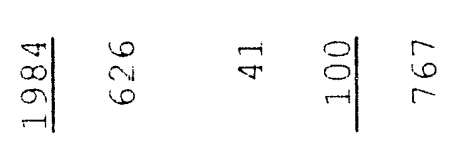

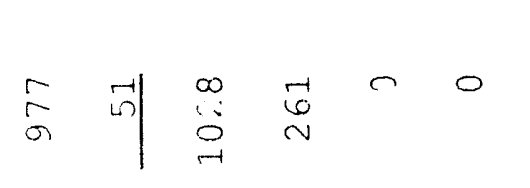

怘
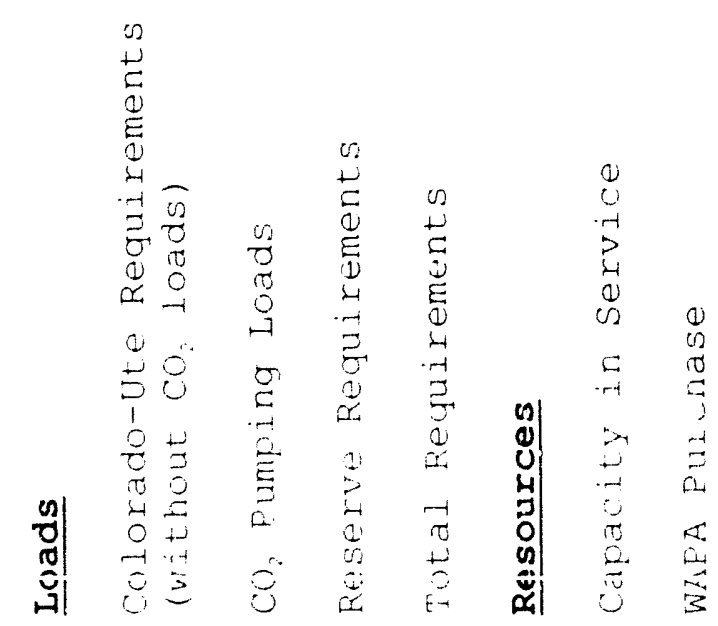

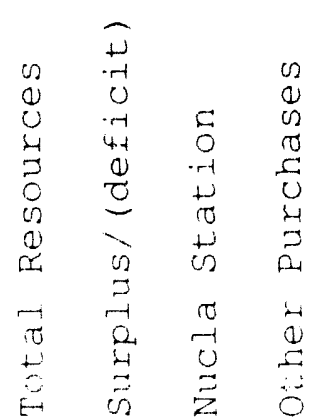

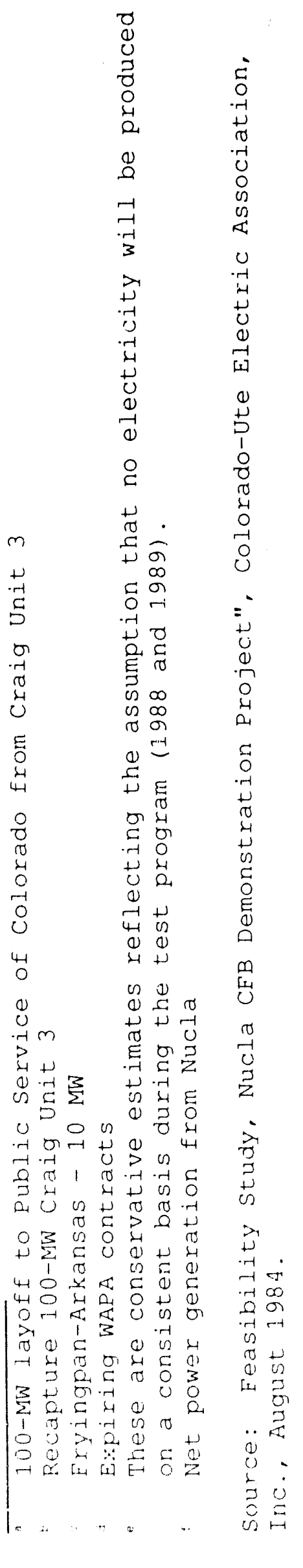


respectively. This site was not selected because none of the existing units were scheduled to be retired in the near future.

Construction of a fluidized bed unit at the Hayden site would have involved the construction of an entirely new unit and three generically different types could cause major problems with operation and maintenance functions.

Craig Station is a coal-fired generating station located approximately four miles southwest of Craig, Colorado, consisting of three similar 417-MW (each) units. This site was not selected because the three existing units were new and constructing a demonstration fluidized-bed combustion unit there would also have required construction of an entirely new facility.

A large amount of generating capacity already existed in the Craig and Hayden area of northwestern Colorado. Colorado-Ute, therefore, preferred to build the additional generation closer to the growing demand in southwestern Colorado.

\section{PROJECT ALTERNATIVES}

Colorado-Ute began the Nucla life extension study by screening the most conceivable options:

- Supplemental natural-gas firing of the existing coal-fired stoker boilers;

- Converting the existing boilers to full natural-gas firing;

- Natural-gas-fired combined cycle with a new combustion turbine;

- An external coal combustor supplying the existing turbinegenerators;

- Coal gasification to supply the existing boilers;

- Coal washing;

- Rebuilding the existing boilers to efficiently burn the local coal;

- Converting the existing boilers to AFBC units;

- Building a new unit at Nucla, either pulverized coal (PC), $A F B C$ or pressurized fluidized-bed combustion (PFBC);

- Building a new PC or AFBC boiler with a topping turbine; and 
- No action, retirement.

The no-action alternative would have led to the closing of Nucla Station. Colorado-Ute found this alternative unacceptable for two reasons. First, it would have meant purchasing more expensive power from other utilities, and subsequently delivering the power to load centers near Nucla. Transmission of electric power over long distances increases the cost of power because of the associated transmission losses. Second, closing Nucla station would have added to the problems of a community where the economy was severely depressed.

First screening of the remaining alternatives indicated that the options that did not include increased generating capacity required considerable capital outlay and were not competitive. Colorado-Ute also eliminated the PFBC system because it did not consider this process to be as close to commercialization as the AFBC technology. Therefore, Colorado-Ute focused on economic alternatives to increase generation capacity based on:

- Conventional PC combustion technology;

- Bubbling $\mathrm{AFBC}$; and

- Circuiating AFBC.

Installing a 100-MW PC boiler was rejected due to significantly higher capital costs, higher fuel costs, the requirements for an $\mathrm{SO}_{2}$ scrubber for sulfur removal and the one- to two-year schedule delay required for an environmental impact statement.

Fuel costs for a PC-fired boiler would be higher than those for a fluidized-bed boiler due principally to higher coal quality requirements. This was based on the presumption that selective mining would be needed to fuel a PC boiler, as was previously employed for the stoker-fired units. In addition, there may be insufficient quantities of coal in the Nucla area of the required quality to fuel a PC-fired unit for a 30-year life extension.

Colorado-Ute, therefore, focused on the AFBC options. Both bubbling and circulating $A F B C$ boilers operate at atmospheric pressure, and the bed temperature usually ranges between $815^{\circ} \mathrm{C}$ to $870^{\circ} \mathrm{C}\left(1,500^{\circ} \mathrm{F}\right.$ to $1,600^{\circ} \mathrm{F}$ ) which helps prevent furnace slagging and minimizes $\mathrm{NO}_{\mathrm{x}}$ emissions. The bubbling bed operates at a lower gas velocity than the circulating and keeps a dense bed of coal and limestone suspended in a bubbling manner in the bottom of the furnace or combustor. The circulating bed operates at a higher gas velocity to entrain the coal and limestone particles in a less dense bed; the particles are then separated from the flue gas stream via a hot 
cyclone collector and recirculated back to the combustor, maximizing carbon and sorbent utilization.

During the summer of 1983, Colorado-Ute began seriously considering a circulating $A F B C$ boiler for Nucla. In comparing a circulatingbed versus a bubbling-bed boiler, Colorado-Ute considered the following factors:

- Capital cost;

- Operating costs;

- Carbon utilization;

- Sulfur capture and stoichiometric $\mathrm{Ca} / \mathrm{S}$ ratios;

- $\mathrm{NO}_{\mathrm{x}}$ emissions;

- Relative design simplicity/complexity of the boiler and its fuel and sorbent feed systems;

- Auxiliary power requirements;

- Experience of boiler manufacturers; and

- Effects on the balance of the Nucla plant.

With the assistance of various organizations (EPRI, DOE, consultants, vendors, and other utilities), Colorado-Ute also investigated air heater designs (regenerative, tubular, plate, etc.), economizer designs (bare versus extended surface), and local Nucla fuel and sorbent sources.

Colorado-Ute's investigations culminated in two EPRI-sponsored boiler design studies conducted by two manufacturers who responded to Colorado-Ute's inquiry (Combustion Engineering/Lurgi * and Pyropower**). The primary objectives of the studies were to develop a preliminary design and a cost estimate for the proposed Nucla project. The result was Colorado-Ute's decision that the circulating AFBC technology was the best alternative for use at the Nucla site.

* Combustion Engineering/Lurgi was a consortium of Combustion Engineering, Inc., of the U. S. and Lurgi Corporation. Lurgi $\mathrm{GmbH}$ of West Germany is the owner of circulating AFBC technology and has licensed its use and patents to Lurgi Corporation.

** Pyropower is a U. S. corporation, in San Diego, California, owned by the Ahlstrom Group, a boiler manufacturer and integrated industrial company headquartered in Helsinki, Finland. 
A significant factor for the Nucla project was the capability of a circulating AFBC boiler to burn the local low-grade 5,384 - 4,440 Calories/kg $(9,700-8,000 \mathrm{Btu} / \mathrm{lb})$, high ash $(26-33 \%)$ coals as mined. The Nucla coal and ash analyses are presented in Tables 2 and 3. Coal B ("Design" coal) listed in Table 2 was used for designing the circulating $A F B C$ boiler equipment and ensures that alternative fuels can be burned during a two-year test program that EPRI funded. The Nucla Station fuel costs are expected to be reduced by $30 \%$ on an equivalent delivered heating value basis by burning the local coals as mined when compared to selective mining for the existing stoker-fired units.

At the time, both boiler manufacturers had considerable experience with industrial-size circulating $A F B C$ boilers. The technology had been used primarily in Europe, whereas bubbling AFBC experience was primarily in the United States. By early 1984, circulating AFBC technology was judged by many to be in a stage of development equivalent to the bubbling-bed technology. The largest operating circulating $A F B C$ boilers were an 84-MW (thermal) unit (Lurgi-W. Germany) and a $90,800-\mathrm{kg} / \mathrm{hr}(200,000 \mathrm{lb} / \mathrm{hr}), 87-\mathrm{kg} / \mathrm{cm}^{2}(1,235 \mathrm{psig})$, $500^{\circ} \mathrm{C}\left(930^{\circ} \mathrm{F}\right)$ unit (Ahlstrom-Finland). The largest operating bubbling-bed boiler was TVA's $20-M W$ pilot unit located at the shawnee Station. Based on their experience with industrial circulating AFBC units, the two manufacturers were willing to provide commercial guarantees for a project.

\section{EVALUATION OF NUCJAA STATION POWER CYCLE ALTERNATIVES}

Colorado-Ute realized that the path to improving station heat rate was elevating the steam conditions. Therefore, to optimize cycle improvement the company turned its attention to studying steam conditions, cycle configurations, and increments of generation addition.

With main steam temperature limited to $538^{\circ} \mathrm{C}\left(1000^{\circ} \mathrm{F}\right)$, current state of the art, and with existing turbine steam inlet conditions of 42$\mathrm{kg} / \mathrm{cm}^{2}(600 \mathrm{psig})$ and $440^{\circ} \mathrm{C}\left(825^{\circ} \mathrm{F}\right)$, Colorado-Ute identified and examined three candidate cycles.:

- a topping turbine cycle;

- a customized supercritical single reheat cycle; and

- an automatic extraction condensing turbine cycle.

The topping turbine cycle could improve turbine cycle heat rate to approximately $9.5 \times 10^{6}$ Joules/kWh $(9,000 \mathrm{Btu} / \mathrm{kWh})$ but added only 7 $\mathrm{MW}$ of capacity to the existing $36 \mathrm{MW}$. When the costs of a new boiler, auxiliaries, and the topping turbine were added to the station 
TABLE 2

NUCLA COAL ANALYSIS

Coal A

Coal B

"Performance" Coal "Design" Coal

Source

Gradation

Proximate Analysis, $\frac{}{6}$ by weight Moisture

Volatile

Fixed carbon

Ash

Total

Ultimate Analysis, $\frac{}{\circ}$ by weight

Carbon

Hydrogen

Sulphur

Oxygen

Nitrogen

Chlorine

Moisture

Ash

Total

Gross Heating Value as Fired:

Calorie/kg (Btu/lb)

Surface Moisture as Fired:

$\frac{0}{0}$ by weight

Ash Softened Temperatures (reducing

Initial deformation

Softening

Fluid
Nucla, $\mathrm{CO}$

Uni form

5.8

26.9

41.2

26.1

100.00
Nucla, $\mathrm{CO}$

Uniform

$$
\begin{array}{r}
6.0 \\
21.0 \\
40.0 \\
33.0^{\circ} \\
\hline 100.00
\end{array}
$$

$\begin{array}{r}55.17 \\ 3.63 \\ 0.73 \\ 7.51 \\ 0.98 \\ 0.04 \\ 5.86 \\ 26.08 \\ \hline 100.00\end{array}$

46.41

3.60

$2.50^{\circ}$

7.50

0.90

0.04

6.00

$\frac{33.05}{100.00}$

$5,380 \quad(9693)$

$4,440 \quad(8000)$

$$
3.74
$$

4.00

atmosphere), ${ }^{\circ} \mathrm{F}$
$\quad 2650$
+2700
+2700

2650

$+2700$

$+2700$

NOTE: Coal A constitutes the basis for all guaranteed and predicted performance data. The circulating AFBC boiler unit is capable of developing specified capacity using Coal B.

- 33.0\% ash and 2.5\% sulfur for Coal B do not occur at the same time. 
TABLE 3

NUCLA ASH ANALYSIS

$\begin{array}{lc}\text { Phos. Pentoxide, } \mathrm{P}_{2} \mathrm{O}_{5} & 0.1 \\ \text { Silica, } \mathrm{SiO}_{2} & 56.1 \\ \text { Ferric Oxide, } \mathrm{Fe}_{2} \mathrm{O}_{3} & 4.7 \\ \text { Alumina, } \mathrm{Al}_{2} \mathrm{O}_{3} & 29.1 \\ \text { Titania, } \mathrm{TiO}_{2} & 1.2 \\ \text { Lime, CaO } & 4.2 \\ \text { Magnesia, MgO } & 0.8 \\ \text { Sulfur Trioxide, } \mathrm{SO}_{3} & 2.7 \\ \text { Potassium Oxide, } \mathrm{Na}_{2} \mathrm{O} & 0.3 \\ \text { Total } & 100.0\end{array}$


reconditioning costs, the investment became unattractive for a $9.5 \mathrm{x}$ $10^{6}$ Joules $/ \mathrm{kWh}(9,000 \mathrm{Btu} / \mathrm{kWh})$ turbine cycle heat rate. Furthermore, the 7-MW increment of generation capacity increase would have little impact on annual coal burn and mining costs.

The customized supercritical single reheat cycle with $246-\mathrm{kg} / \mathrm{cm}^{2}$ $(3,500 \mathrm{psig})$ and $538^{\circ} \mathrm{C}\left(1000^{\circ} \mathrm{F}\right)$ main steam and $440^{\circ} \mathrm{C}\left(825^{\circ} \mathrm{F}\right)$ reheat steam supplying the existing turbine generators could improve turbine cycle heat rate to approximately $8.4 \times 10^{6} \mathrm{Joules} / \mathrm{kWh} \quad(8,000$ $\mathrm{Btu} / \mathrm{kWh})$. However, the complication of reheat being superimposed on the evolving circulating AFBC boiler technology and the prototype nature of the small supercritical turbine seemed to be prudent. The circulating AFBC boiler manufacturers showed little enthusiasm for reheat and for a once-through boiler design. Supercritical steam conditions have most commonly been applied to machines having a rating in excess of $300 \mathrm{MW}$ which is far in excess of anything considered for the Nucla Station. Furthermore, the requirements for controlling high-pressure cylinder exhaust steam pressure introduced an altogether new and complex speed/load control system. While these control aspects have been developed for auto extraction turbines, they have not been applied to a supercritical reheat turbire cycle configuration. Furthermore, reheating steam to only $440^{\circ} \mathrm{C}$ $\left(825^{\circ} \mathrm{F}\right)$ is not really cost effective.

The automatic extraction condensing turbine cycle proved to be the optimum choice. Colorado-Ute determined that an automatic extraction turbine with throttle steam conditions in the area of 102 $\mathrm{kg} / \mathrm{cm}^{2}(1,450 \mathrm{psig})$ and $538^{\circ} \mathrm{C}\left(1000^{\circ} \mathrm{F}\right)$ could be applied. The design for such a turbine at ratings up to $75 \mathrm{MW}$ were well established. However, the extraction cycle, as its name implies, requires extraction.

Automatic extraction would supply steam to the existing turbines at $42-\mathrm{kg} / \mathrm{cm}^{2}\left(600 \mathrm{psig}\right.$ and $440^{\circ} \mathrm{C}\left(825^{\circ} \mathrm{F}\right)$. The exhaust end of the extraction turbine would be designed for the maximum inlet flow less the design extraction flow to the existing turbines. This turbine heat rate is approximately $9.3 \times 10^{6}$ Joules/kWh $(8,800 \mathrm{Btu} / \mathrm{kWh})$. The turbine cost premium for the automatic extraction feature over a conventional turbine of the same rating was of the order of $10 \%$.

There was a limited range within which the generation increment increase could be considered. The upper limit of 100 to $150 \mathrm{MW}$ was set by the plant site physical limitations and the power requirements, voltage, and stability considerations of the existing $115-\mathrm{kV}$ transmission system.

Finally Colorado-Ute decided to add a new 74-MW steam turbine. The demonstration project thus called for a new circulating AFBC boiler which would supply steam to the new 74-MW turbine-generator and the three existing 12-MW turbine-generators, a new baghouse, chimney, 


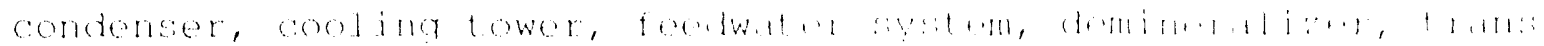

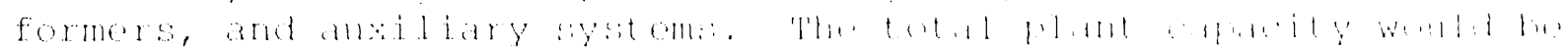

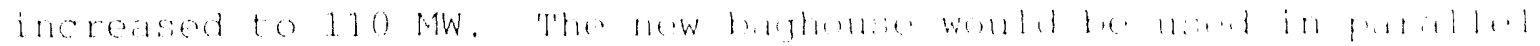

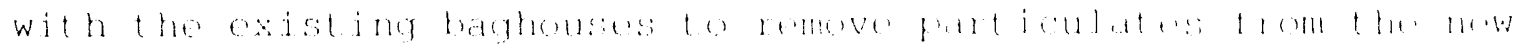

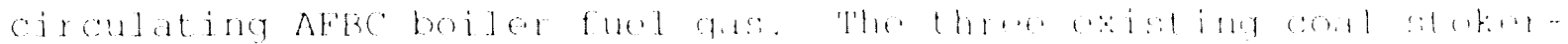

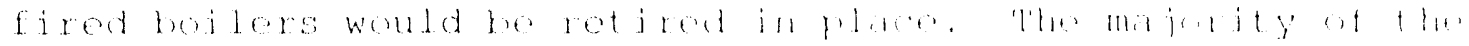

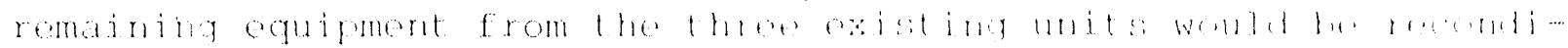

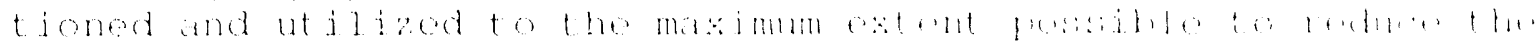
total project cost.

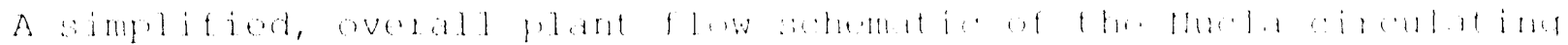

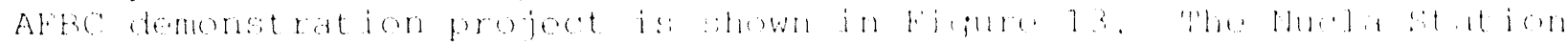

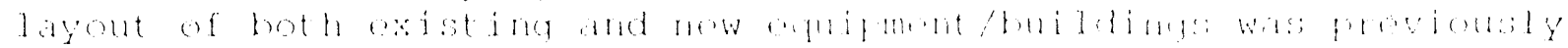

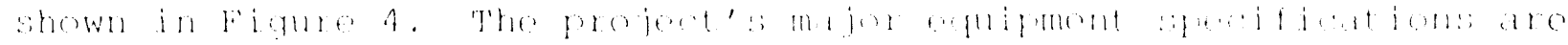

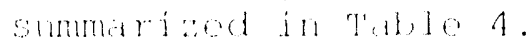

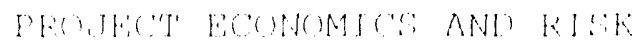

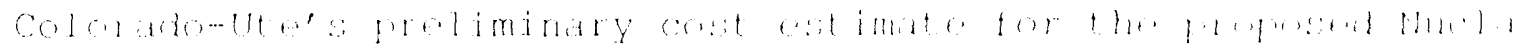
oj

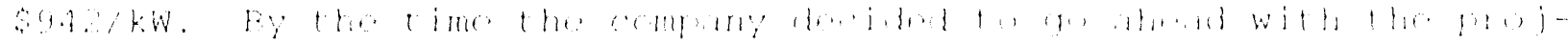

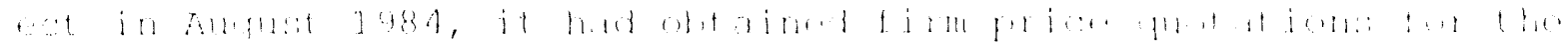

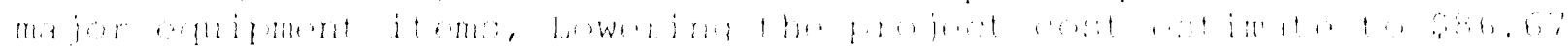

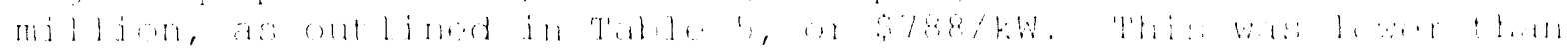

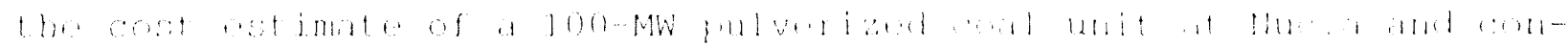

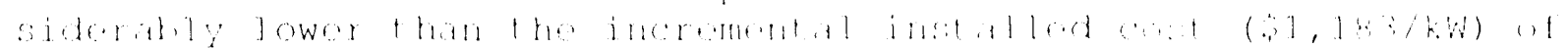

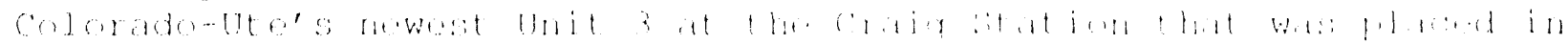

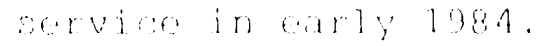

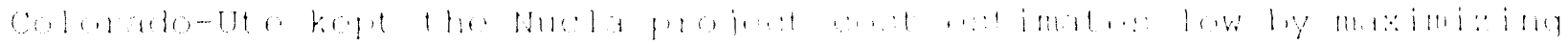

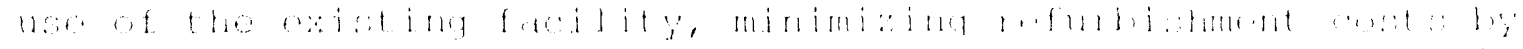

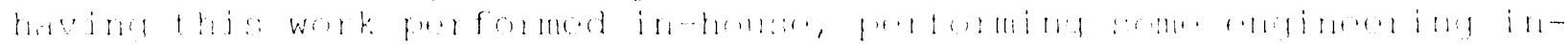

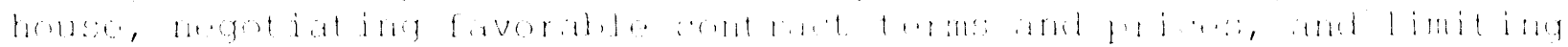

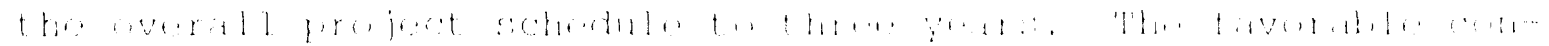

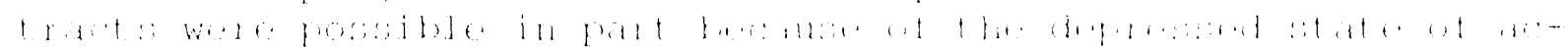

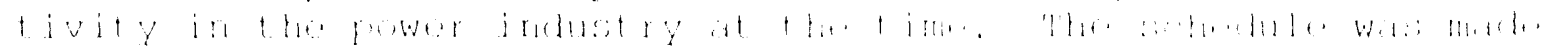

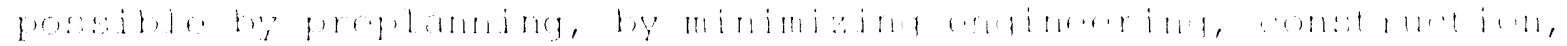

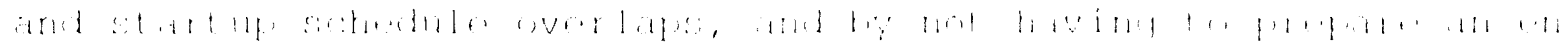

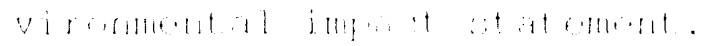

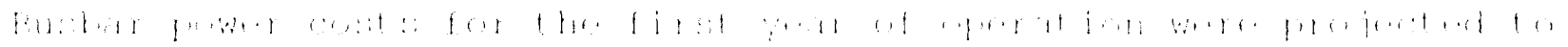

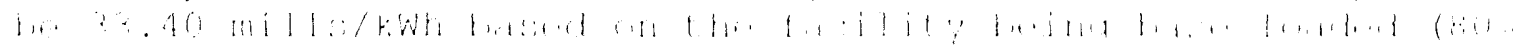

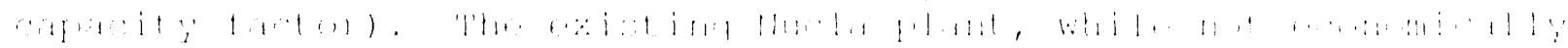

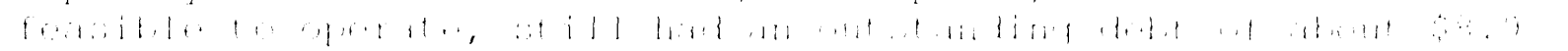

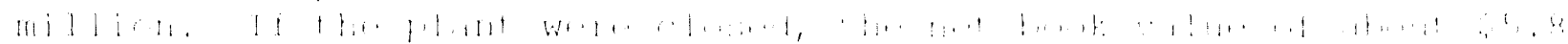

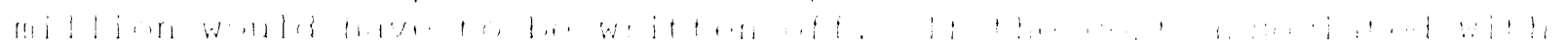

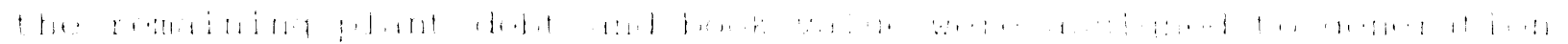

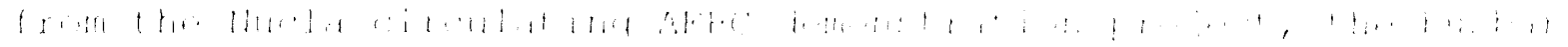




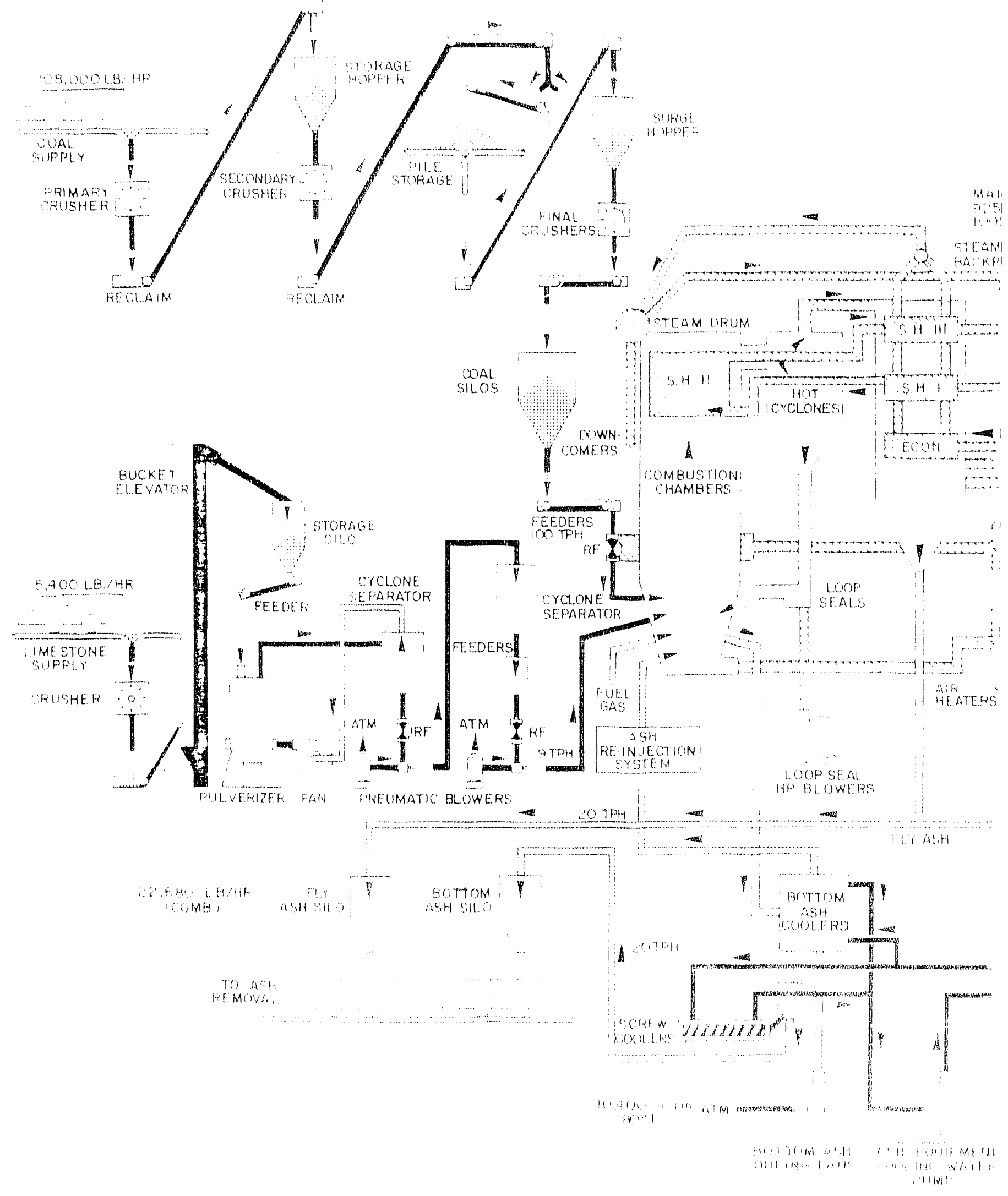




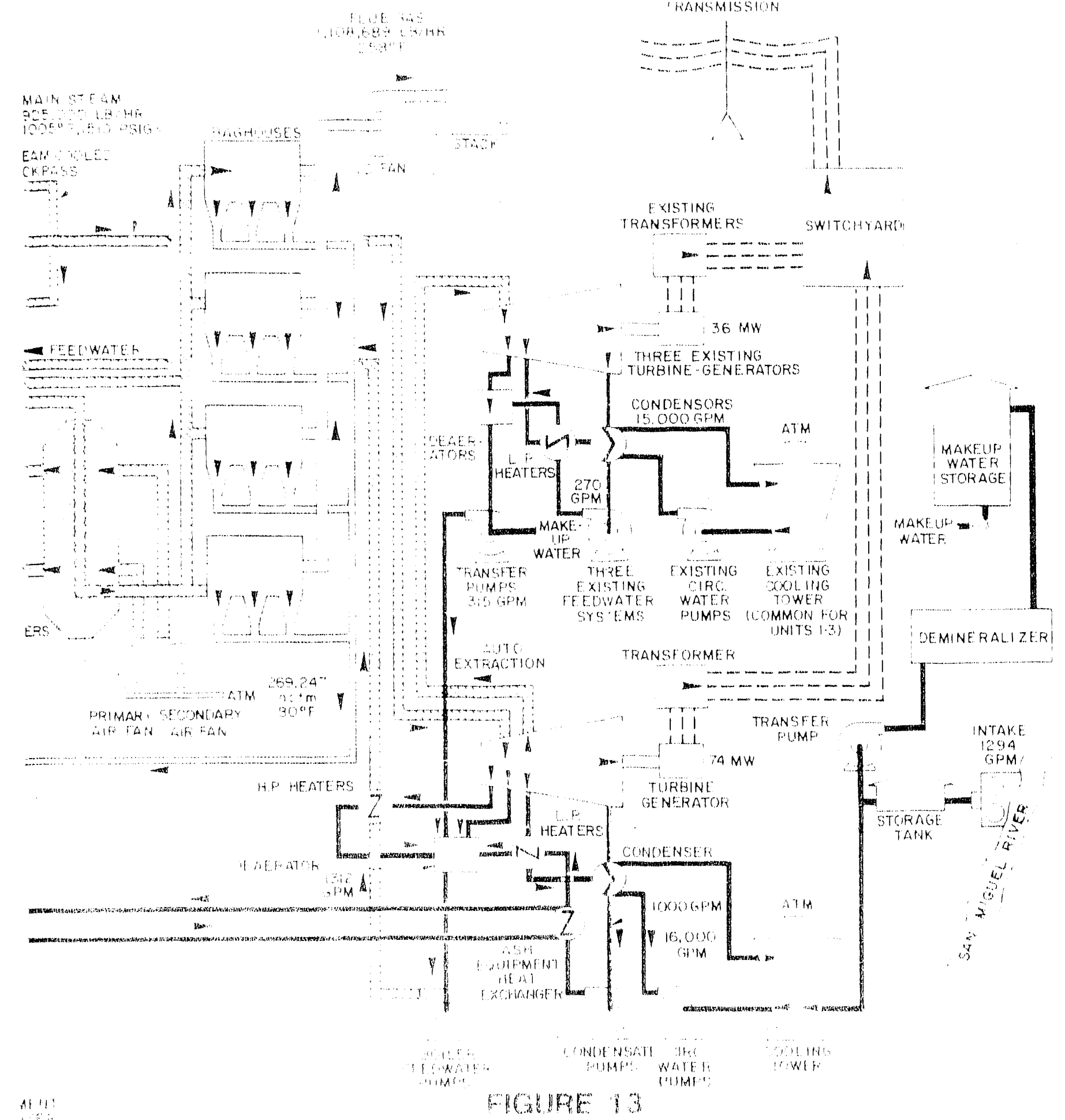

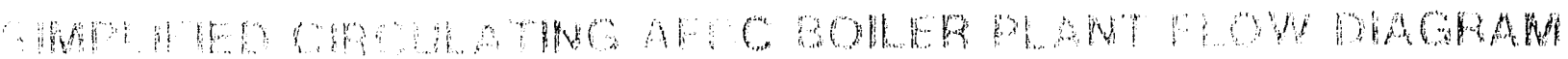


TABLE 4

SUMMARY OF EQUIPMENT S'PECIEICATIONS

BOIIER

Type

Steam flow, 1b/hr - max. continuous rating

Superheater outlet pressure, psig

Superheater outlet temperature, ' $\mathrm{F}$

Comulustion rate, Btu/hr $\times 10^{6}$

Coal consumption, ton/hr

Number of coal feeders

Limestone consumption, ton/hr

Number of limestone feeders

\section{PRIMARY AIR FAN}

Capacity, 1000 acfm at boiler rating Drive

Type

$\mathrm{HP}$

Manufacturer
Adjustable frequency synchronous motor

3,500

westinghouse

AMERICAN DAVIDSON

66.1

\section{SECONDARY AIR FAN}

Capacity, 1000 acfm at boiler rating

$\frac{\text { AMERICAN DAVIDSON }}{213.9}$

Adjustable frequency induction motor 700

Westinghouse

AMERICAN DAVIDSON 447.8

Capacity, 1000 acfm at boiler rating Adjustable frequency synchronous motor 3,250

HP

Manufacturer
Westinghouse

\section{BAGHOUSES *}

Number - (1-new + 3-existing) Effluent particulate loading, 1b/106 Btu
RESEARCH-COTTRELL/WHEELABRATOR-ERYE

4.03

* The new Research-Cottrell baghouse will operate in parallel with three existing Wheelabrator-Frye baghouses and will process approximately $50 \%$ of the flue gas.

* United Conveyor - new; Allen-Sherman-Hoff - existing. 
TABLE 4 (Continued)

SUMMARY OF EQUIPMENT SPECIFICATIONS

ASH HANDLING FACILITIES

Spent Bed Ash

Type

Capacity, ton/hr

Silo storage, cu ft

Fly Ash

Type

Capacity, ton/hr

Silo storage, cu ft
UNITED CONVEYOR/ALIEN SHERMAN HOEF** *

Vacuum pneumatic

20

10,940

Vacuum pneumatic

30

60,000

WESTINGHOUSE

TURBINE GENERATOR

Type

Continuous output, MW with full extraction

Throttle steam flow, $1 \mathrm{~b} / \mathrm{hr}$ with full extraction

Generator continuous, KVA

Extraction steam pressure, psig

Extraction steam temperature, ${ }^{\circ} \mathrm{F}$

74

925,000

88,200

625

800

EXISTING TURBINE GENERATORS $1,2,3$

Output, MW each

Steam source

Throttle steam flow, lb/hr each

DELAVAL

$$
12.6
$$

Unit 4 extraction 123,000

\section{CONDENSER}

Surface area, $1000 \mathrm{sq} \mathrm{ft}$

Number of water passes

Air removal equipment

SOUTHWESTERN

45.7

2

Steam air jet ejector

\section{BOILER FEED PUMPS}

Number

Capacity of each, gpm

Total developed head, ft

Drive

Type

HP of each

Manufacturer

BYRON JACKSON

2

1,312

4,368

Motor

1,750

Westinghouse

\footnotetext{
* The new Research-Cottrell baghouse will operate in parallel with three existing Wheelabrator-Frye baghouses and will process approximately $50 \%$ of the flue gas.

** United Conveyor - new; Allen-Sherman-Hoff - existing.
} 
TABLE 4 (Continued)

SUMMARY OF EQUIPMENT SPECIFICATIONS

\section{FEEDWATER HEATERS}

Number of closed heaters, HP/LP

Final feedwater temperature, ${ }^{\circ} \mathrm{F}$

DEAERATOR

Number

Type

\section{SOUTHWESTERN}

$2 / 2$

439

GRAVER

1

Direct contact

* The new Research-Cottrell baghouse will operate in parallel with three existing Wheelabrator-Frye baghouses and will process approximately $50 \%$ of the flue gas.

$\star \star$ United Conveyor - new; Allen-Sherman-Hoff - existing. 
TABLE 5

ESTIMATEL CAPITAL COSTS SUMMARY

(September 1984 Dollars)

\section{Estimated Costs Based Upon Firm Price Quotes}

Boiler

Turbine-Generator

ArchitectiEngineer

Total
29.98

7.0

3.2

40.18

\begin{tabular}{lr} 
Estimated Costs Without Eirm Price & Quotes \\
\hline Earthwork & 0.36 \\
Concrete & 1.36 \\
Structural/Architectural & 0.87 \\
Mechanical Equipment & 9.23 \\
Piping & 2.81 \\
Instrumentation and Controls & 0.43 \\
Electrical Equipment & 3.45 \\
Painting & 0.01 \\
Insulation & 0.92 \\
Demo, Reloc, and Mod & 0.40
\end{tabular}

19.84

Field Distributable Costs 4.55

Contractor Home Office Costs and Fees 4.88 T'otal

Total field Cost and Contract Engineering

69.45

5.60

and Construction Management

Project Contingency

Total Plant cost

AFDC

Total Project C.ost

Project Participation

Total with Project Participation

86.67

$\frac{(2.74)}{83.93}$

$\underline{83.93}$

Additional Costs Related to Existing Plant

Book Value

5.79

Accumulated Interest, Taxes and Insurance

Total Plant Investment

92.15

Total Plant Investment

Source: "Feasibility Study, Nucla CFB Demonstration Project," Colorado-Ute Electric Association, Inc., August 1984. 
power cost, for accounting purposes, would increase by 1.58 mills/kWh to $34.98 \mathrm{mills} / \mathrm{kWh}$. This compared favorably with Colorado-Ute's 1984 wholesale rate to members of $41.17 \mathrm{mills} / \mathrm{kWh}$. The assumptions for determining this estimate and related costs are presented in Table 6.

\section{EPRI PARTICIPATION}

In December 1981, EPRI solicited interest from various utilities to host an AFBC demonstration project in the range of 100 to $200 \mathrm{MW}$. After beginning its Nucla station life extension study in mid-1982, Colorado-Ute became interested in the merits of the new AFBC technology for Nucla. Colorado-Ute approached EPRI in the fall of 1982, offering its Nucla station as a candidate host site for EPRI's proposed 100-200 MW AFBC demonstration unit in an attempt to obtain technical and financial assistance for the project. EPRI invited Colorado-Ute to submit a formal proposai in accordance with published guidelines issued in November 1982.

In February 1983, Colorado-Ute prepared and submitted a detailed proposal to EPRI for its Nucla AFBC demonstration project. This initial proposal was for a new 100-MW bubbling AFBC boiler with a reheater. In mid-1983 EPRI chose to support TVA's bubbling AFBC project. Colorado-Ute then became interested in the alternative circulatirig AFBC technology and continued its dialogue with EPRI. Colorado-Ute obtained initial vendor capital cost estimates for a circulating AFBC type boiler that were significantly lower, approximately $\$ 8$ million or $\$ 70 / \mathrm{kW}$, than for the bubbling AFBC. Based on these estimates, the company decided that the proposed project was justified on its cwn merits without outside financial support, and in september 1983, announced its intention to proceed with the Nucla circulating AFBC project to be completed by the fourth quarter of 1987. Risk funding was the only remaining major concern.

In the fall of 1983, EPRI responded positively to Colorado-Ute's continuing efforts, with funding that totaled $\$ 177,000$ for a twopart circulating $A F B C$ design study. Part 1 of this study was to address design of a new circulating AFBC boiler applicable to the Nucla site, and part 2 to address the issue of scaling up the circulating $A F B C$ boiler size to $500 \mathrm{MW}$ for an undetermined site.

In the winter of 1983-1984, Colorado-Ute received the study results and prepared a detailed project estimate based on two different circulating AFBC boiler designs. The estimates verified an earlier projection of $\$ 103$ million for the full project. This was before Colorado-Ute received firm price quotations that subsequently lowered the final project estimate to $\$ 87$ million. 
TABLE 6

PROJECTED FIRST-YEAR OPERATING COSTS

\section{Assumptions}

Total Project cost

Pollution Control Equipment Costa

Interest Rate

Pollution Bond Rate

Coal Cost

Limestone cost

Depreciation Rate

Property Tax Rate

Insurance Rate

Net Plant Capacity

Net Init (Plant) Heat Rate

Annual Capacity Factor

Coal Required

Net Generation

$\$ 86,67$ million (from Table 5)

$\$ 15$ million

$12.0 \%$

6.5 옹

$\$ 19 /$ ton

$\$ 16 /$ ton

$3.1 \%$ per year

$1.17 \%$

$0.15 \%$

$100 \mathrm{MW}$

$11,500 \mathrm{Btu} /$ net $\mathrm{kWh}$

$80.0 \%$

415,000 tons/year

$701 \mathrm{GWH} / \mathrm{yr}$

Operating Costs Category

Costs

Busbar Costs

Interest Costs

(millions of dollars)

9.248

(mills/kWh)

Depreciation, Insurance, Taxes

3.706

13.20

Fixed O\&M

1.420

5.29

Variable O\&M

0.608

2.03

Coal

7.893

0.87

Limestone

0.219

11.26

Ash Disposal

0.163

0.31

Water

0.046

0.23

Natural Gas

0.075

0.06

General Chemicals

Total

$\frac{0.030}{23.408}$

0.11

$\frac{0.04}{33.40}$

Costs related to existing plant

value and debt

Total

$\frac{1.104}{24.448}$

$\frac{1.58}{34.98}$

Colorado-Ute's present (1984) firm wholesale rate to members 41.17

This includes the circulating AFBC boiler combustion chambers, bed letdown equipment, hot cyclones and loop seals; plus the baghouse, limestone and ash handling equipment, and stack monitoring equipment. Note that subsequently this type of financing was not chosen. However, at the time of the feasibility study it was assumed that approximately $\$ 15$ million would be financed with a 6.5 \% interest rate.

Source: "Feasibility Study, Nucla CFB Demonstration Project," Colorado-Ute Electric Association, Inc., August 1984. 
In exchange for EPRI's technical assistance and financial support, Colorado-Ute agreed to make available the circulating AFBC boiler for two years of testing. This program is part of a large EPRI effort, it also includes the bubbling AFBC projects at TVA's Shawnee Station and Northern States Power Company's Black Dog Station and it is designed to support AFBC technology development and provide the last critical link between laboratory test facilities and commercial operating power plants. Data and experience gained will broaden the knowledge base on $A F^{\prime} B C$ and reduce the risk for future plant designs using the technology.

At Nucla Station, EPRI will conduct a comprehensive series of tests on the circulating $A F B C$ generator over a two-year period. The unit size is ideal for linking small experimental and industrial-scale data and experience with future scale-up efforts. The scope of the test program includes steady-state performance testing, continuous performance monitoring of plant components and special tests to identify effects of coal characteristics on boiler operation.

EPRI's total budget commitment for the project is limited to approximately $\$ 14$ million, to include the preliminary boiler studies, special test instrumentation, the two-year test program, project reporting, and compensation to Colorado-Ute for negatively affected generation revenues during the project testing phase.

\section{DOE PARTICIPATION}

The past interest in AFBC technology by the U.S. Department of Energy is well documented. This led Colorado-Ute to investigate the possibility of obtaining a Cooperative Agreement under the clean Coal Tecinology Program - Phase I. In April 1986 an application was filed by Colorado-Ute with the DOE and this culminated in cooperative Agreement, DE-FC21-89MC25137. Department of Energy assistance amounted to $\$ 19.92$ million in project testing support and began in Alugust 1988. The DOE program administration became the responsibility of the Morgantown Energy Technology Center located in Morgantown, west Virginia.

\section{ENVIRONMENTAL AND SOCTOECONOMIC CONSIDERATIONS}

On March 17, 1983, the Colorado Public Utilities Commission granted a Certificate of Public Convenience and Necessity for the Nucla project. The remainder of the permit and licensing process was relatively easy and straightforward, primarily due to the project being a retrofit of an existing plant.

Preliminary environmental reviews by the United State Environmental protection Agency and the Colorado Department of Health disclosed that no significant environmental impacts would be associated with the Nucla project. 
The construction of a circulating AFBC project at the existing Nucla Station would not affect wetlands, flood plains, threatened or endangered species, prime farmlands, or cultural resources. The project would be constructed at the existing coal-fired Nucla station site and no additional land would be needed. Further, no new transmission lines would be constructed in connection with it.

Circulating AFBC combustion represents a cleaner method of burning coal than currently existed at the Nucla station, and would result in lower total emissions of $\mathrm{SO}_{2}$ and particulates. Even though the plant output would be increased from $36 \mathrm{MW}$ to $110 \mathrm{MW}$, $\mathrm{NO}_{\mathrm{x}}$ emissions were expected to decrease based on circulating AFBC combustor testing. This included testing of the Nucla coal in a circulating AFBC pilot combustor, which showed $\mathrm{NO}_{x}$ emissions to be 0.2 to $0.3 \mathrm{lb} / 10^{6}$ Btu.

The impacts to areas that could be susceptible to acid deposition would be rediced because the $\mathrm{SO}_{2}$ emissions would be reduced. The Nucla project would not cause any visibility impacts in Federal Class 1 or Class 2 areas. A Prevention of Significant Deterioration (PSD) permit was required and obtained.

Water for the Nucla project is available from the San Miguel River which flows next to the station. Water quality in the San Miguel River would not be impacted by operation of the circulating AFBC unit. Nucla Station had a current Colorado Waste Water Discharge Permit. The proposed life extension modification would discharge more flow than did the existing station but effluent concentrations would be the same as in the existing permit, which could be modified to reflect these changes.

The socioeconomic impact of constructing and operating the proposed circulating AFBC unit at the Nucla site would be very positive. The Nucla area, including the towns of Nucla, Naturita, Norwood and Uravan, was hard hit by cutbacks and shutdowns in uranium mining and processing facilities. It was expected that a portion of the work force needed for construction of the Nucla project would be recruited from the Nucla area, although workers with specialized construction skills might come from outside the area.

To help ensure that local labor was used during construction, Colorado-Ute included a special feature in the "Project Labor Agreement". This feature called for utilization of the local labor force to help minimize unemployment and stabilize the local economy. The local unions were to strive to furnish $50 \%$ of the work force from the immediate Nucla area communities.

The "Project Labor Agreement" was negotiated by Coloracio-Ute with 21 local unions, and their respective internationals, affiliated with the Colorado Building and Construction Trades Council. All 
Colorado-Ute's contractors and subcontractors were required to become signatory to the "Project Labor Agreement".

Existing housing, law enforcement, hospitals, schools and other support facilities were considered adequate to accommodate the construction work force and their families.

Costs for constructing the Nucla circulating AFBC demonstration project were monitored throughout the project and categorized according to an AFBC code of accounts. This provides consistency, which will make future comparisons of project cost elements possible. However, this code was developed by the Electric Power Research Institute (EPRI) and although used in all AFBC demonstration projects, it is not presented herein due to availability and non-completion of this particular project.

Section 2 of this report describes the circulating AFBC boiler equipment and integral systems. The section discusses the functional boiler operating system, which include the circulating AFBC boiler (including a summary of the circulating fluidized-bed combustion process and boiler components), the coal and limestone feed systems, the combustion air and flue gas systems, the solids separation and recycle system, boiler miscellaneous equipment, plus, the boiler startup system, and boiler instrumentation and controls.

Section 3 details the boilex plant material-handling equipment and related systems. These include: the coal-handling system, the limestone-handling system, and the ash-handling systems. The general design/functional description and specific data are presented for each material-handling system plus major equipment items within. The material-handling descriptions and data include information about the old plant equipment and systems, as well as the new plant equipment and systems.

Section 4 discusses balance-of-plant mechanical equipment and systems, which are support facilities. These include piping, water supply and circulating systems, the condenser, chemical feed plus miscellaneous HVAC, air, hoist, lubrication, fire protection and startup fuel gas systems. Both new and existing plant information is included and tied together.

Section 5 presents the turbine-generator and balance-of-plant electrical equipment and inherent systems. This section discusses functional operating systems and includes all plant equipment and systems not included in the previous sections. Again, the general design/functional description and data are presented for each operational system and equipment item. The turbine and balance-of-plant descriptions and data include information about the old plant equipment and systems, as well as the new equipment and systems that comprise the balance of the overall power plant facility. 
Section 6 contains the plant instrumentation and controls equipment and systems. The nerve system of a power plant includes all controls, alarms, annunciators, displays, panels and emission monitoring as well as others. Again both new and existing systems have been integrated into the discussion.

Section 7 describes special test equipment and facilities installed for EPRI's contract and two-year test program to study the Nucla circulating AFBC boiler and its operating characteristics.

Appendix A contains the plant equipment and data information list. Appendix $B$ is bound separately and presents process flow and instrumentation drawings, which are non-proprietary. Appendix C also was bound separately and is not available for public distribution, due to Pyropower proprietary process flow and instrumentation drawings. Appendix $D$ is included herein and provides a list of the Technicai Advisory Group. 
Section II. Circulating AFBC Boiler systems

\subsection{Circulating AEBC Boiler}

The circulating $A F B C$ boiler is a coal-fired, balanced draft, circulating fluidized-bed boiler supplied by Pyropower Corporation, a subsidiary of the A. Ahlstrom Corporation. It has a maximum continuous rating of $420,000 \mathrm{~kg} / \mathrm{hr}(925,000 \mathrm{lb} / \mathrm{hr})$ of superheated steam at $106-\mathrm{kg} / \mathrm{cm}^{2}(1510 \mathrm{psig})$ and $540^{\circ} \mathrm{C}\left(1005^{\circ} \mathrm{F}\right)$.

Included in this section under the circulating AFBC boiler heading is a summary description of the Nucla circulating fluidizedbed boiler combustion process and components. The coal-and limestone-feed systems consist of independent coal and limestone equipment that regulates the flow of coal and limestone from silos into the boiler combustors. The air and flue gas system includes the boiler combustion air supply from the draft fan intakes to the combustion chambers and the flue gas discharge from the boiler to baghouses and the stack. The solids separation and recycle system contains the circulating AFBC boiler hot cyclones and loop seals that recycle bed material back to the combustion chambers. The boiler startup system is comprised of the startup and duct burners. The boiler instrumentation and controls include the boiler-mounted instruments and the circulating $A F B C$ boiler operating procedures. Circulating $A F B C$ boiler system equipment data is included in Appendix A together with $P \& I D$ drawings which are non-proprietary in Appendix $B$.

\section{1 .1 Process and Component Summary}

The primary circulating $A F B C$ boiler sections are:

- Two combustion chambers

- Two hot cyclone collectors

- A common convection section.

The Nucla unit design performance is summarized in Table 7. A sectional side view of the Nucla circulating $A F B C$ boiler is presented in Figure 14.

Combustion and sulfur-absorption reactions (calcination and sulfation) take place in the combustion chambers, which are fully water cooled using a membrane-type wall construction. Primary air, which is used for fluidizing the bed and maintaining the proper air-to-fuel ratio, is introduced through 
Table 7

CIRCULATING AFBC BOILER PERFORMANCE SUMMARY

Superheater outlet:

Steam flow

Steam temperature

Steam pressure

Boiler design pressure

Sootblowing steam:

Flow

Pressure

Temperature

Fuel input:

Coal $A$ *

Coal B *

Drum pressure:

Economizer:

Inlet pressure

Inlet temperature

out let temperature

Excess air:

Primary air:

Air temperature

Secondary air:

Air temperature

Elue gas flow:

Heat release:

Boiler efficiency:

Elue gas temperatures:

Leaving combustors (furnace)

Leaving air heater

Boiler emission limits:

Particulates

$\mathrm{NO}_{x}$

$\mathrm{SO}_{2}$
$420,000 \mathrm{~kg} / \mathrm{hr}$

$521+6^{\circ} \mathrm{C}$

$106 \overline{\mathrm{kg}} / \mathrm{cm}^{2}$

$124 \mathrm{~kg} / \mathrm{cm}^{2}$

$12,250 \mathrm{~kg} / \mathrm{hr}$

$113 \mathrm{~kg} / \mathrm{cm}^{2}$

$427^{\circ} \mathrm{C}$

$52,850 \mathrm{~kg} / \mathrm{hr}$

$65,010 \mathrm{~kg} / \mathrm{hr}$

$116 \mathrm{~kg} / \mathrm{cm}^{2}$

$119 \mathrm{~kg} / \mathrm{cm}^{2}$

$227^{\circ} \mathrm{C}$

$280^{\circ} \mathrm{C}$

$20 \%$

$190^{\circ} \mathrm{C}$

$184^{\circ} \mathrm{C}$

$501,100 \mathrm{~kg} / \mathrm{hr}$

$1.19 \times 10^{12} \mathrm{~J} / \mathrm{hr}$

$88.27 \frac{\circ}{\circ}$

$871^{\circ} \mathrm{C}$

$126^{\circ} \mathrm{C}$

$13 \mathrm{ng} / \mathrm{J}$

$215 \mathrm{ng} / \mathrm{J}$

$172 \mathrm{ng} / \mathrm{J}$
$(1,103,700 \quad 1 b / h r)$

$(925,000 \mathrm{lb} / \mathrm{hr})$

$\left(1005+10^{\circ} \mathrm{F}\right)$

(1510 psig)

(1760 psig)

$(27,000 \mathrm{lb} / \mathrm{hr})$

(1610 psig)

$\left(801^{\circ} \mathrm{F}\right)$

$(116,400 \mathrm{lb} / \mathrm{hr})$

$(143,200 \mathrm{lb} / \mathrm{hr})$

(1655 psig)

(1689 psig)

$\left(440^{\circ} \mathrm{F}\right)$

$\left(536^{\circ} \mathrm{F}\right)$

$20 \%$

$\left(374^{\circ} \mathrm{F}\right)$

$\left(363^{\circ} \mathrm{F}\right)$

$\left(1,128 \times 10^{6} \mathrm{Btu} / \mathrm{hr}\right)$

$88.27 \%$

$\left(1600^{\circ} \mathrm{F}\right)$

$\left(258^{\circ} \mathrm{F}\right)$

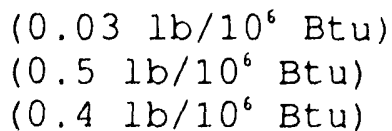

ॠ Reference Table 3 


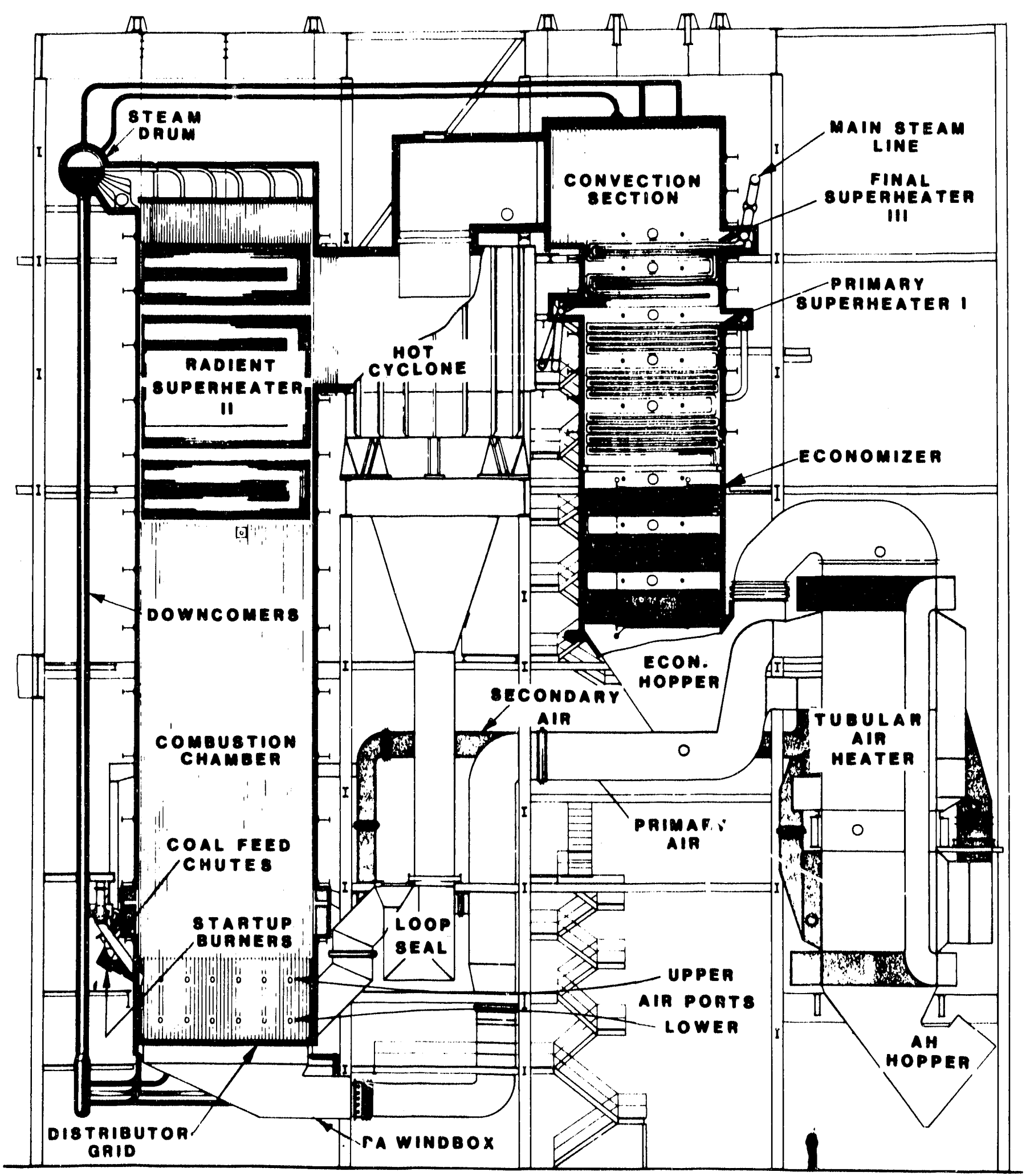

FIGURE 14

CIRCULATING AFBC BOILER - SECTIONAL SIDE VIEW SOURCE: PYROPOWER CORPORATION 
both the bottom distributor grid nozzles, where the bed material is fluidized, and the lower wall ports located in all four walls of each combustion chamber for bed mixing. Secondary air, which is used to ensure complete combustion and to reduce $\mathrm{NO}_{x}$ emissions, is introduced through wall ports located above the primary air ports in the lower zone of the combustion chambers (see Figure 14).

The fluidized-bed material consists of unreacted coal, unreacted limestone, calcined limestone, ash, and calcium sulfate. Ninety to ninety-five percent of the bed material is spent (reacted) limestone, inert ash, and calcium sulfate. only a very small amount of the bed material is unburned coal. The slip velocity between gas and solids, as well as the turbulent nature of the circulating fluid bed, provides excellent mixing and temperature distribution, conditions necessary for optimum performance. Particles in the mid-section and upper portion of the combustors comprise the entrained, less-dense material that elutriates from the combustion chambers to the hot cyclones. The primary means of heat transfer in the combustion chambers is by a combination of conduction and convection from the fluidized bed to the waterwall enclosure and superheater surfaces.

The two combustion chambers consist of rectangular gas-tight enclosures each $6.9 \mathrm{~m}$ (22 ft, 8.25 -in.) wide by $7.4 \mathrm{~m}(24 \mathrm{ft}$, 2.75-in.) deep and approximately $34 \mathrm{~m}(110 \mathrm{ft})$ high. Coal is fed into each combustor from three locations, two in the front wall and one in the bed recycle loop seal. The loop seal recycle port is located in the combustion chamber rear wall. Limestone is pneumatically fed into each combustor from four feed ports, with two located on the front wall, one on the outside sidewall, and one on the rear wall of each combustor. spent bed ash is drained from each combustor to ash coolers through two bottom ash drain ports located on the outside sidewalls at the distributor grid elevation. The distributor grid floor is comprised of membrane water-cooled tubes that slope toward these spent bed ash drain ports. The ash coolers are also connected to the combustors by equalizing ports located above the spent bed ash drain ports.

Four radiant superheater sections are located in the upper zone of each combustion chamber (see Figure 14). Each combustor radiant superheater section is arranged horizontally adjacent to the combustor front and sidewalls. Heat transfer to these superheater sections is primarily by a combination of conduction and convection from the circulating bed material.

The elutriated bed material and flue gas leave each combustion chamber through a waterwall-cooled duct section conrected to 
the top rear corner of each combustor. The combustion chamber outlet duct section is connected to each hot cyclone inlet by a refractory-lined expansion joint.

The two hot cyclone collectors, one per combustion chamber, separate entrained bed particles from the flue gas stream. The collected particles are recirculated by gravity through nonmechanical loop seals back to the lower zone of the combustion chambers.

The hot cyclones are each approximately $7 \mathrm{~m}(23 \mathrm{ft}$.$) in diam-$ eter. The round cyclone flue gas outlet ducts are connected to a transition duct that, in turn, is connected to a common rectangular convection zone inlet. The loop seals are connccted directly to the bottom of the cyclones. The hot cyclones, cyclone inlet and outlet ducts, and loop seals are internally lined with layers of both erosion resistant and insulating refractory with a total thickness of approximately $30 \mathrm{~cm}$ (12 in.).

The hot cyclone outlet transition duct is connected to the convection zone inlet by a refractory-lined expansion joint similar to the combustion chamber outlet/hot cyclone inlet connections. These circulating bed recycle section (hot cyclones and loop seals) expansion joints are provided to permit differential expansion between the bottom-supported hot cyclones and loop seals and the top-supported combustion chambers and convection section.

Flue gas leaving the two cyclone collectors continues to the common convection zone, imparting heat via convective heat transfer to the final superheater, primary superheater, and economizer areas. From the convection zone the flue gas continues through the tubular air heater, baghouses, induced draft (ID) fan, and it is then discharged to the stack.

The convection cage is formed by a steam-cooled membrane-type wall that encloses the final and primary superheater sections. The steam-cooled membrane walls comprise the inlet portion of the primary superheater. The economizer is enclosed by steel casing.

Combustion air is supplied by centrifugal, variable-speed motor-driven primary and secondary air fans. Primary and secondary air is heated in a tubular air heater before delivery to the combustion chambers. Primary air is supplied to the following locations: (1) below the air distribution grid at the bottom of the combustion chambers, (2) to lower wall ports located around the periphery of the combustion chambers, (3) to the rear-wall, loop-seal coal injection ports, and, 
finally, to the startup burners. Secondary air is supplied to a level of wall ports above the primary air ports located around the lower periphery of the combustor chambers and to the front-wall coal injection ports. High-pressure air (aiding the recirculation of bed materials through the nonmechanical 100, seals) is supplied by elther of two full-capacity, high-pressure loop seal blowers. An ash-cooling fan is supplied to cool, fluidize, and classify spent bed letdown ash entering the ash coolers. Elght limestone air blowers are provided to pneumatically convey limestone from the feeders into the combustion chambers.

Feedwater is supplied to the economizer at a temperature of $227^{\circ} \mathrm{C}\left(440^{\circ} \mathrm{F}\right)$ and $119 \mathrm{~kg} / \mathrm{cm}^{2}(1689 \mathrm{psig})$, where it is heated before delivery to the steam drum. From the steam drum, the boiler water is delivered via downcomers to the combustion chamber waterwalls, where it recelves additional heat from the combustors and is then returned via risers as steam/water mixture to the steam drum. Boiler water circulates naturally between the steam drum and the combustion chamber waterwall heat absorption surfaces.

Steam flows from the steam drum to the convection cage section located at the outlet of the hot cyclone collectors. The saturated steam is routed through the convection cage, which forms a steam-cooled enclosure, to the primary superheater. The primary and final superheaters are located in the convection area and are supported by the economizer outlet tubes. Steam flows from the primary superheater to the final superheater via radiant superheat sections located in the upper zone of each combustion chamber. Two intermediate stages of superheater attemperation (desuperheating) are used to control final steam temperature. Two first-stage attemperators are located between the primary superheater and the combustion chamber radiant superheater, and two second-stage attemperators are located between the radiant superheaters and the final superheater section.

Fuel (coal) and sorbent (limestone) are fed from boiler silos to the combustion chambers via independent feed systems. The coal and limestone feed systems both utilize gravimetric-type feeders to provide controlled feed of both presized coal and limestone from silos into each circulating AFBC boiler combustion chamber. Coal is fed into each combustor at three locations, and limestone is fed into each combustor at four locations. A coal feeder and rotary valve are provided for each combustor coal feed port. Coal flows by gravity from the feeders and rotary valves into the combustors. One limestone 
feeder is provided for each combustor. Limestone is pneumatically corveyed from each feeder by four pneumatic conveying trains per raniustor, one per limestone feed port.

Each combustion chamber bottom material (spent bed) is removed from the combustors to four air-and-water cooled, ash-fluidizing cooler/classifiers (two $100 \%$ capacity ash cooler/ciassifiers per combustion chamber). This material is discharged through rotary seal valves to surge hoppers (one surge hopper per combustion chamber). Spent bed material is discharged to the bottom ash removal system either directly from the surge hopper or using a water-cooled screw conveyor, depending or its temperature. The screw coolers are required for supplemental bottom ash cooling when the solids temperature in the surge hopper exceeds $204^{\circ} \mathrm{C}\left(400^{\circ} \mathrm{F}\right)$.

The principal design criteria and specifications for site environmental, fuel, ash, limestone, and water for the Nucla circulating AFBC boller are presented in Tables 8, 9, 10, 11 and 12 , respectively. A simplifled process flow diagram of the Nucla circulating $A F B C$ boiler is presented in Figure 15. 
Table 8

PLANT SITE ENVIRONMENTAL DESIGN PARAMETERS

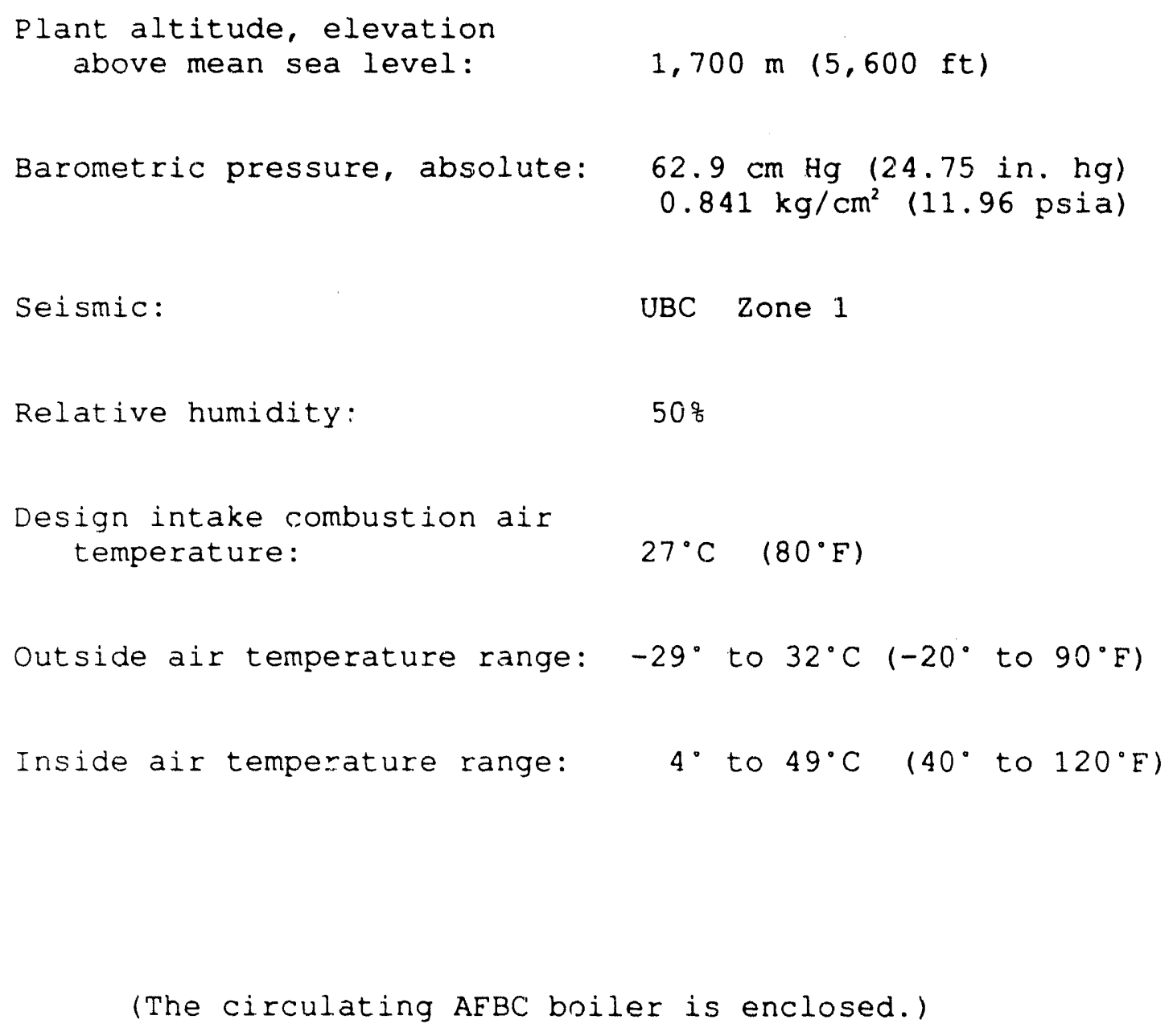


Table 9

COAL FUEL ANALYSIS

Coal

Source

Gradation

Moisture

Volatile

Fixed Carbon

Ash

Total
Proximate analysis, $\frac{\circ}{0}$ by weight:

$A$ *

Performance Coal

Nucla, CO

Uniform

5.8

26.9

41.2

$\frac{26.1}{100.0}$

Ultimate analysis, $\frac{\circ}{\circ}$ by weight:

Carbon

Hydrogen

Sulfur

oxygen

Nitrogen

Chlorine

Moisture

Ash

Total

Gross heating value as fired:

$\mathrm{J} / \mathrm{kg}$ :

(Btu/ lb)
55.17

3.63

0.73

7. 51

0.98

0.04

5.86

$\frac{26.08}{100.00}$

$\mathrm{J} / \mathrm{kg}$ :

$10.26 \times 10^{6}$

(9693)
$B$

Lesign Coal

Nucla, co

Uniform

$$
\begin{aligned}
& 6.0 \\
& 21.0 \\
& 40.0 \\
& \frac{33.0}{100.0}
\end{aligned}
$$

46.41

3.60

$2.5 \star \star$

7.5

0.90

0.04

6.00

$-33.05$

100.00

Surface moisture as fired, o by weight:

3.74

$8.47 \times 10^{5}$

(8000)

Ash softening temperatures (reducing atmosphere, ${ }^{\circ} \mathrm{C}\left[{ }^{\circ} \mathrm{F}\right]$ ):

Initial deformation $\quad 1454 \quad$ (2650)

1482 (2700)

Softening

Fluid

$1482(2700)$

* Coal analysis as tabulated in Column A constitutes the basis for all guaranteed and predicted performance data. The circulating $A F B C$ boiler unit is capable of developing specified capacity using coal analysis as tabulated in Column B. Also, the Column B coal ensures that the boiler will be capable of burning alternative fuels during EPRI's two-year test program.

$\star \star 2.5 \%$ sulfur and $33.0 \%$ ash for coal "B" does not occur at the same time. 
Table 10

ASH MINERAL ANALYSIS ( $\%$ by weight)

$\begin{array}{lr}\text { Phos, pentoxide, } \mathrm{P}_{2} \mathrm{O}_{5} & 0.1 \\ \text { Silica, } \mathrm{SiO}_{2} & 56.1 \\ \text { Ferric oxide, } \mathrm{Fe}_{2} \mathrm{O}_{3} & 4.7 \\ \text { Alumina, } \mathrm{Al}_{2} \mathrm{O}_{3} & 29.1 \\ \text { Titania, } \mathrm{TiO}_{2} & 1.2 \\ \text { Lime, CaO } & 4.2 \\ \text { Magnesia, MgO } & 0.8 \\ \text { Sulfur trioxide, } \mathrm{SO}_{3} & 2.7 \\ \text { Potassium oxide, } \mathrm{K}_{2} \mathrm{O} & 0.8 \\ \text { Sodium oxide, } \mathrm{Na}_{2} \mathrm{O} & 0.3\end{array}$

Total

100.0 
Table 11

LIMESTONE ANALYSIS ( $\frac{\circ}{\circ}$ by weight)

The following analysis is typical of the limestone coloradoUte uses:

$\begin{array}{ll}\mathrm{CaCO}_{3} & 80-98 \% \\ \mathrm{SiO}_{2} & 0.2-0.9 \% \\ \mathrm{MgCO}_{3} & 0.6-18.0 \% \\ \text { Others } & \text { Trace }\end{array}$


Table 12

WATER ANALYSIS

Boiler water concentrations:

Total dissolved solids

1000 ppm maximum

Free $\mathrm{OH}$

less than $2.0 \mathrm{ppm}$

Total suspended solids

$5.0 \mathrm{ppm}$

Silica

$1.1 \mathrm{ppm}$

Feedwater quality:

$\begin{array}{ll}\text { Total dissolved solids } & 0.5 \mathrm{ppm} \text { maximum } \\ \text { Silica } & 0.01 \mathrm{ppm} \\ \mathrm{pH} & 8.8-9.2 \\ \text { Oxygen } & \text { less than } 0.007 \mathrm{ppm} \\ \text { Iron } & \text { less than } 0.01 \mathrm{ppm} \\ \mathrm{CO}_{2} & \text { less than } 1 \mathrm{ppm} \\ \mathrm{Copper} & \text { less than } 0.005 \mathrm{ppm} \\ \text { Organics } & \text { less than } 1 \mathrm{ppm}\end{array}$




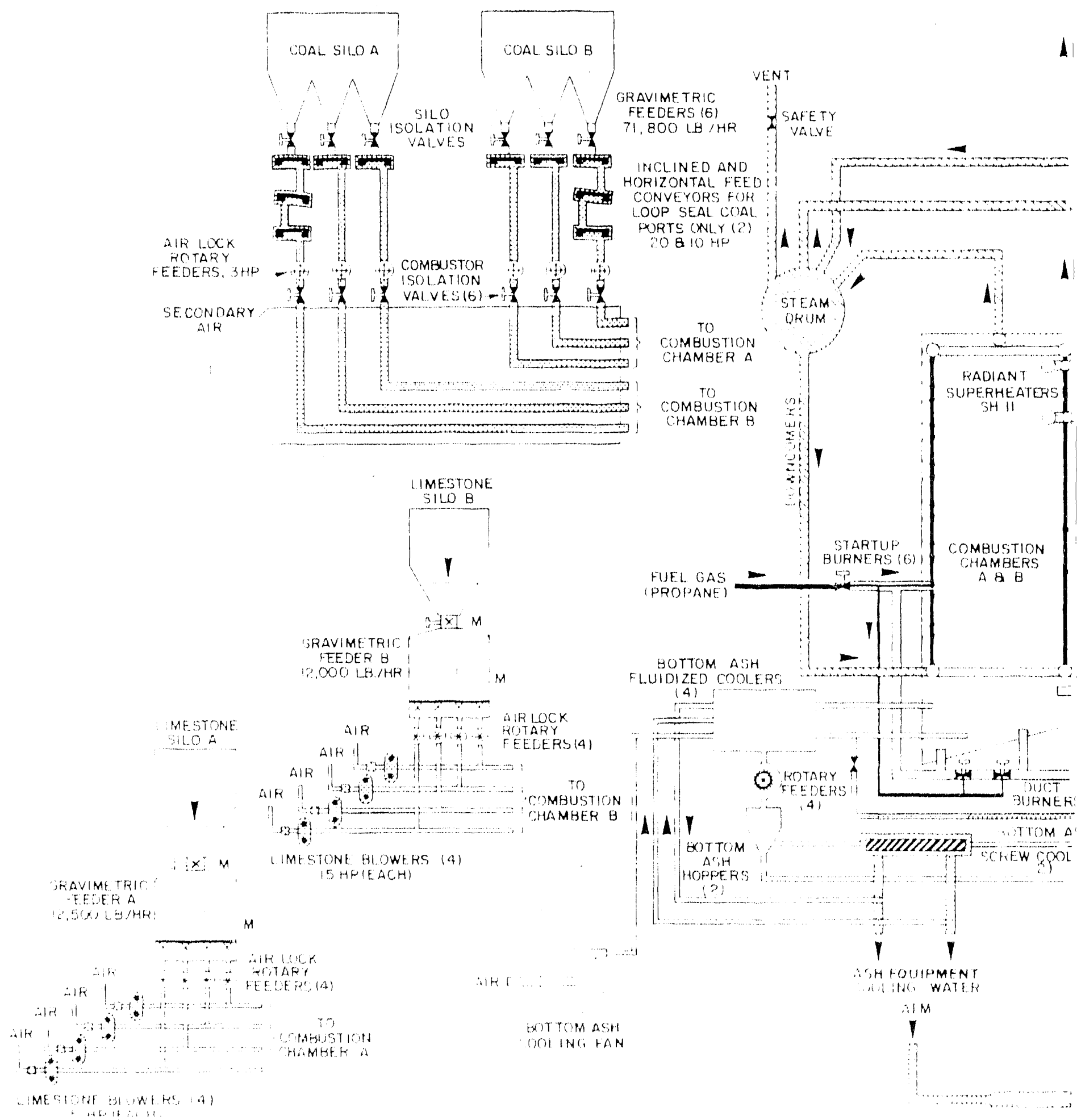

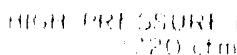




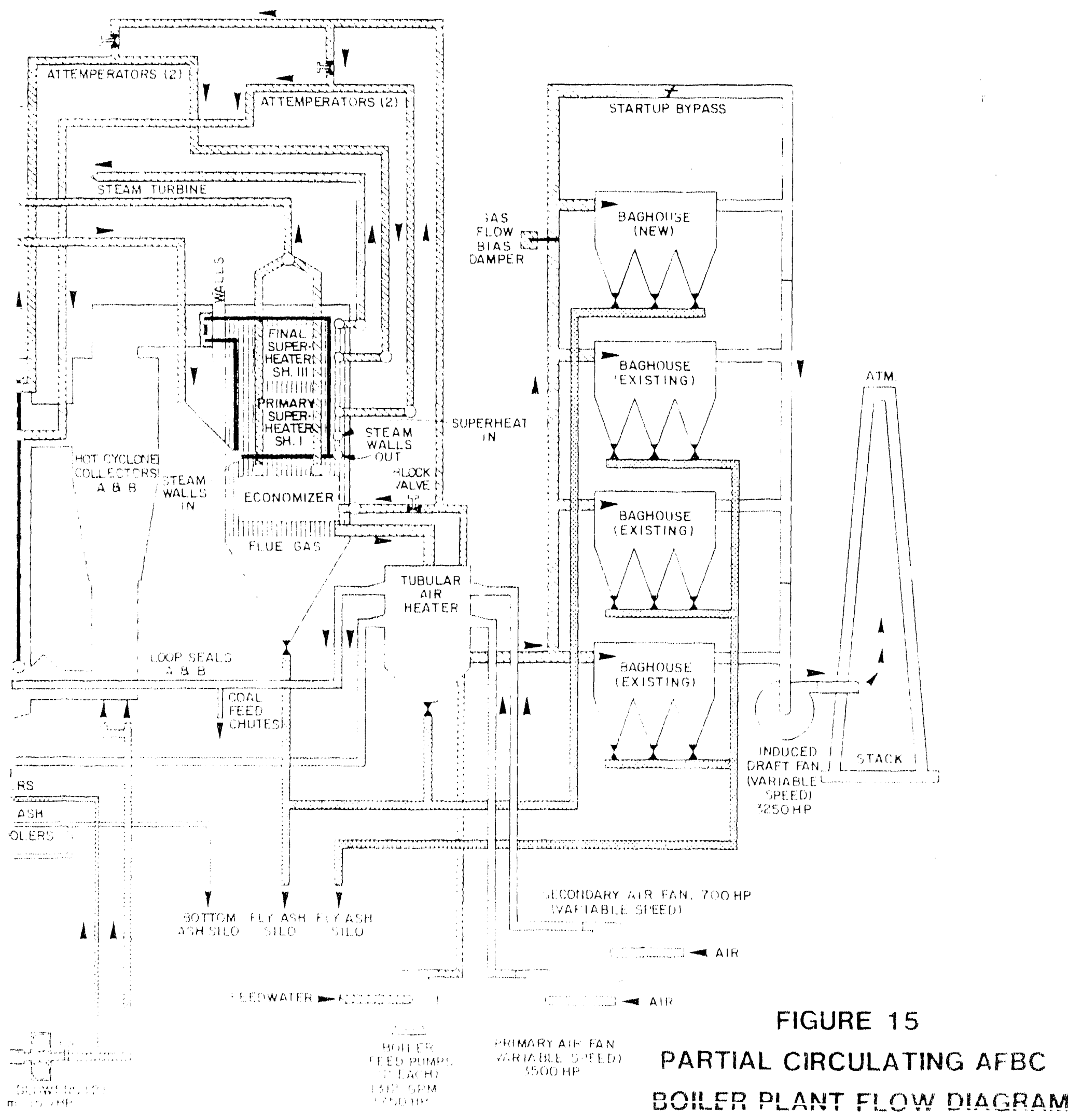




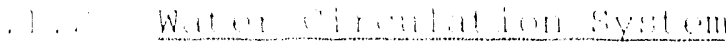

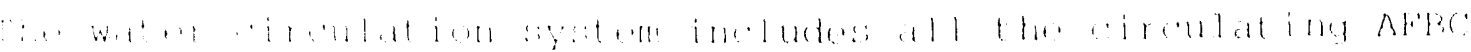

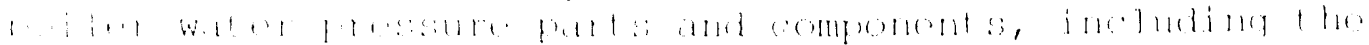

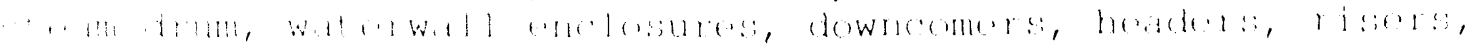

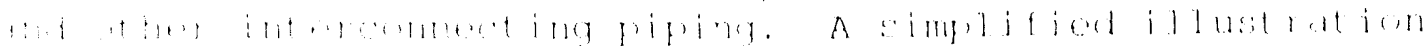

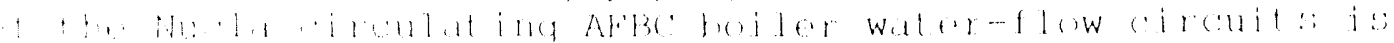

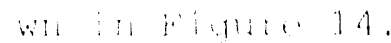

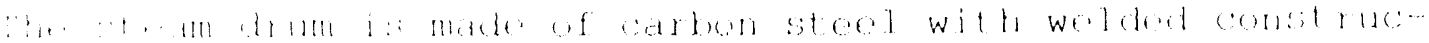

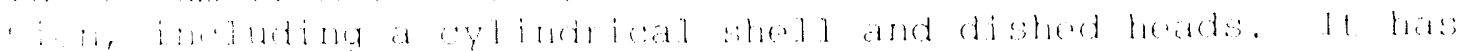

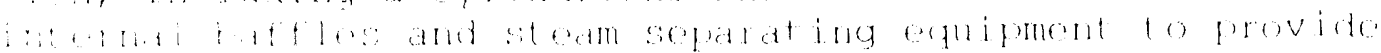

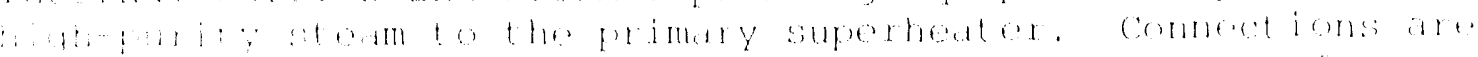

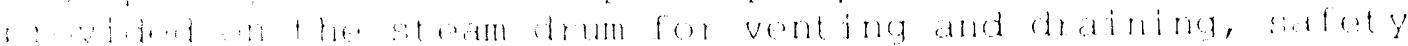

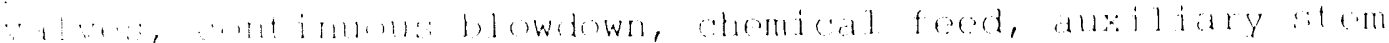

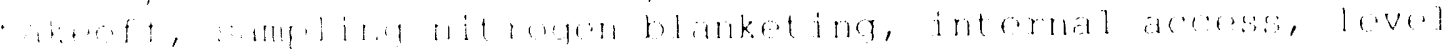

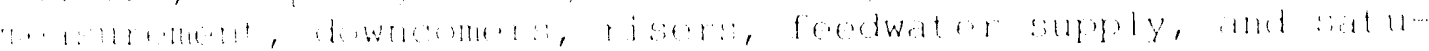

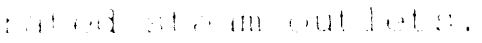

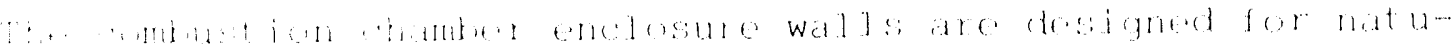

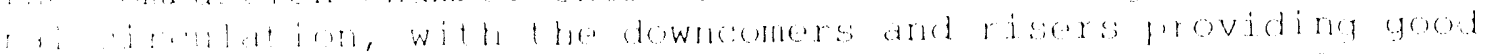

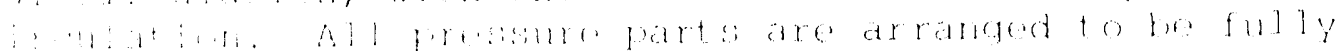

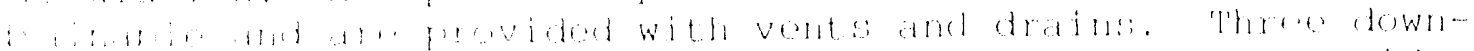

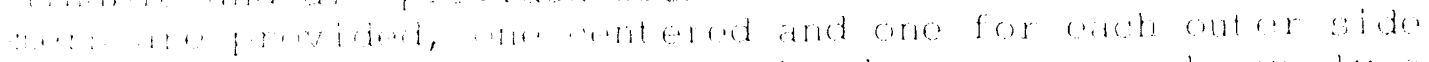

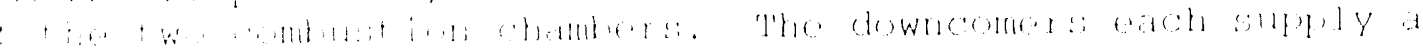

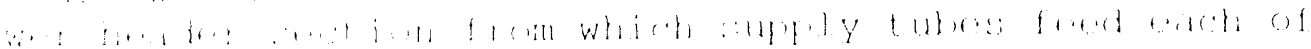

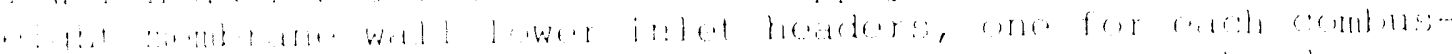

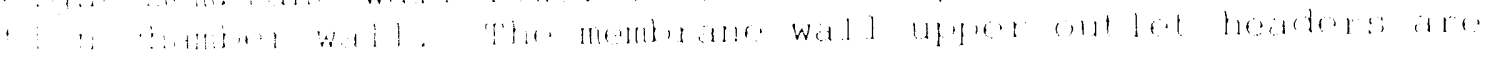

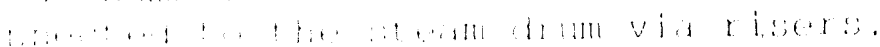

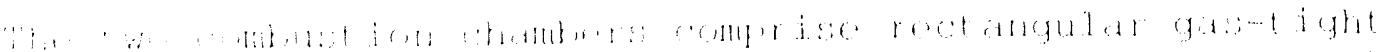

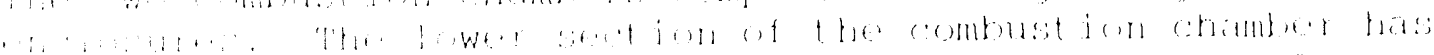

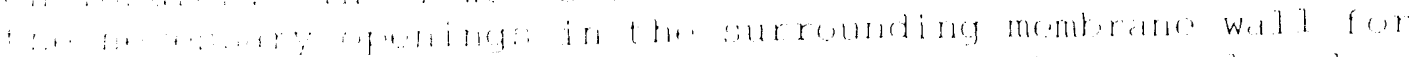

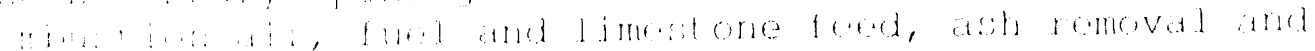

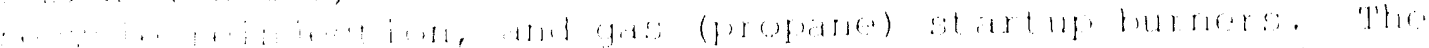

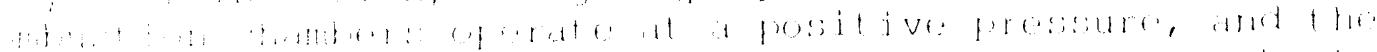

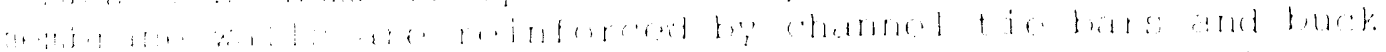

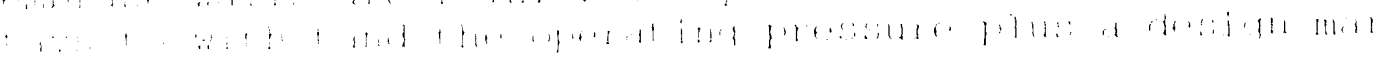

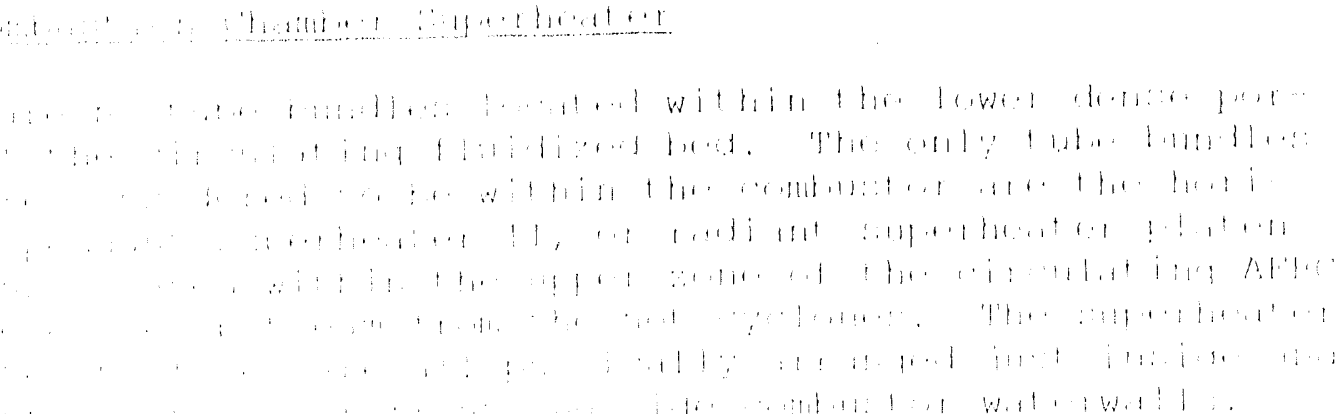


Heat transfer to these superhoder soct ins is grominam ly by a combination of radiation and convoction. l'ter tukn bunks; are located adjacent to the upper tront and both aidowalls of

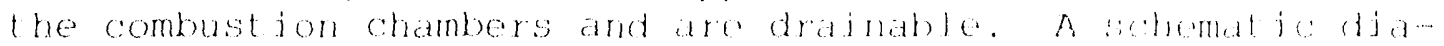

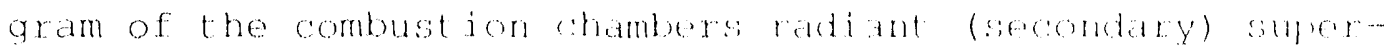
heater (sH-11) sections is prosented in figune lo.

\subsubsection{Backease Heat Tranter sulace}

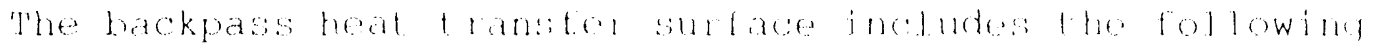
omponents:

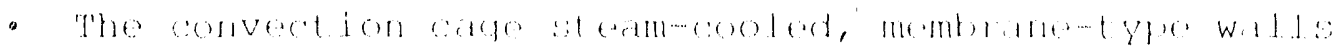

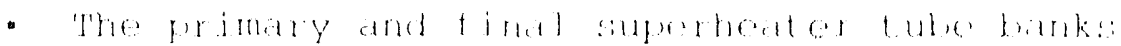

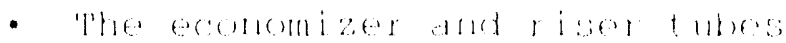

- besmporhaters

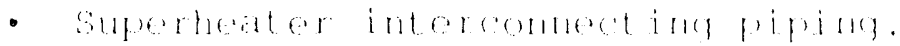

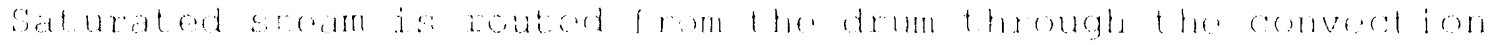

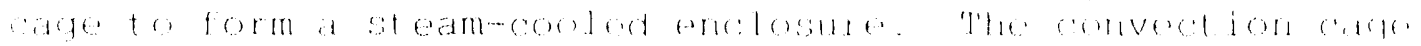

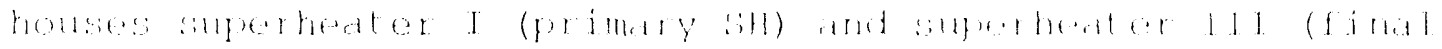

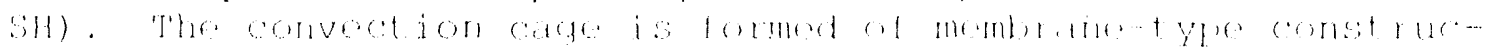

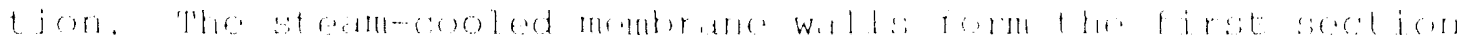

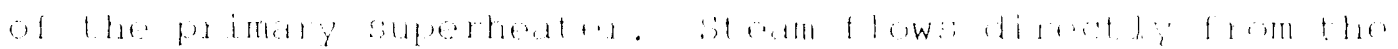

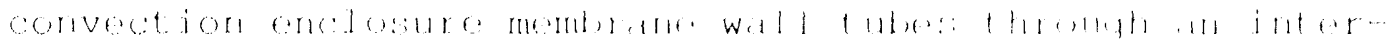

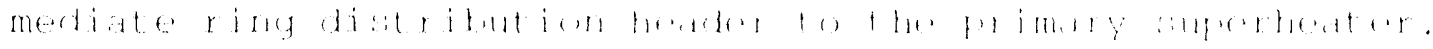

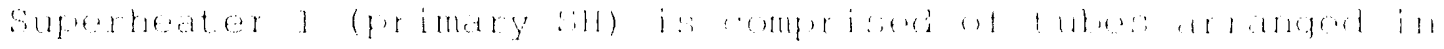

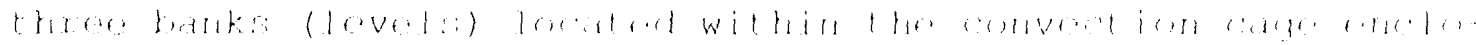

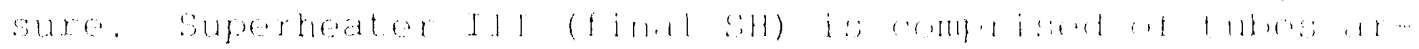

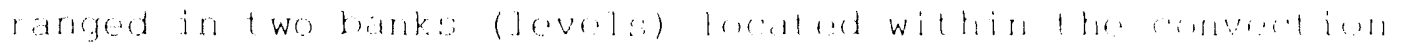

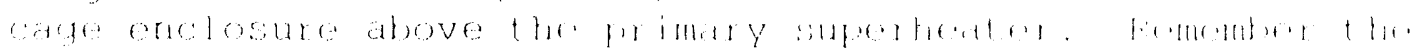

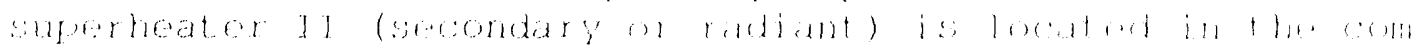

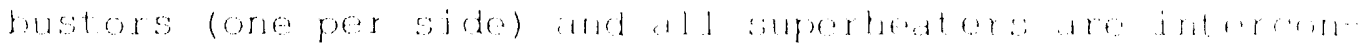

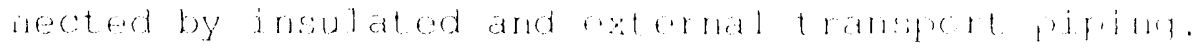

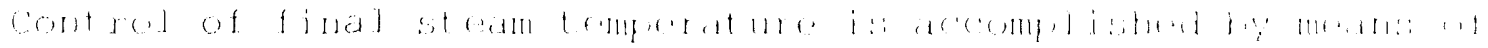

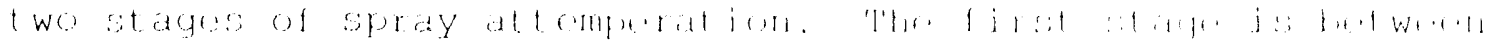

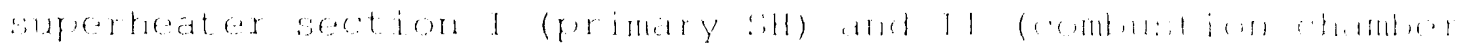

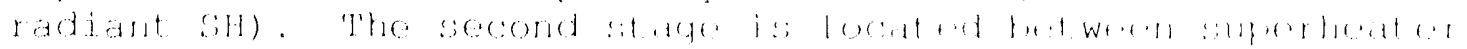
sect ion 11 and soction 111 (findl $\quad$ in).

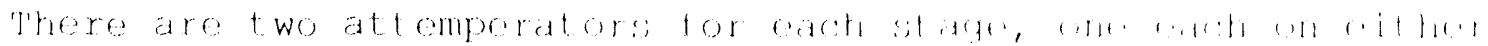

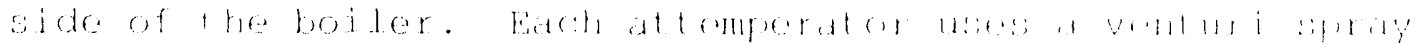

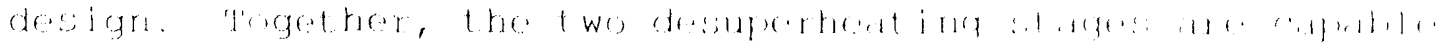

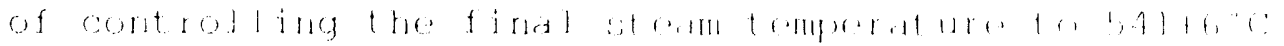

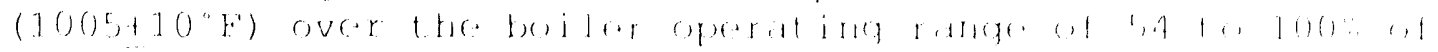

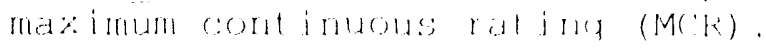




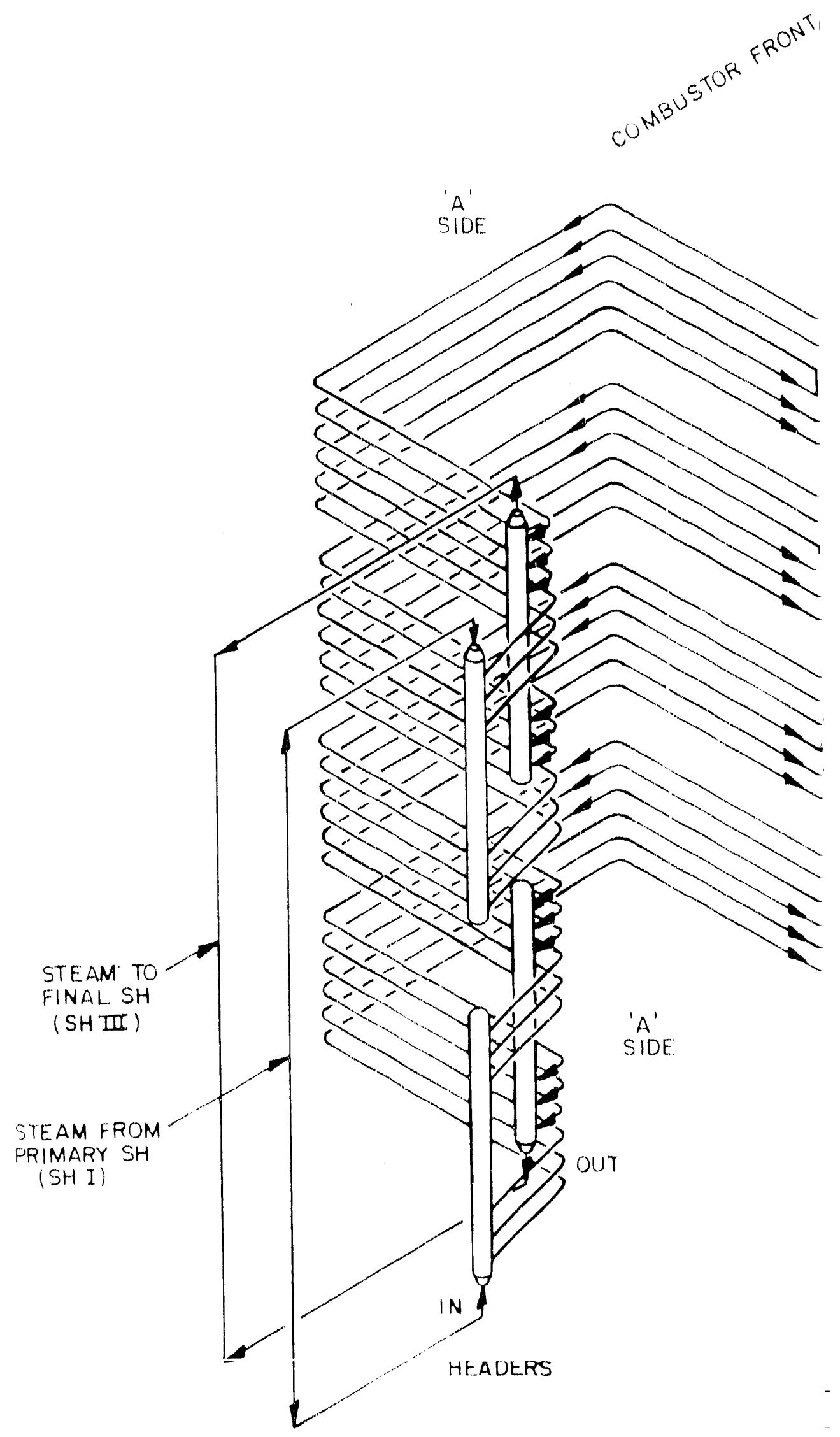




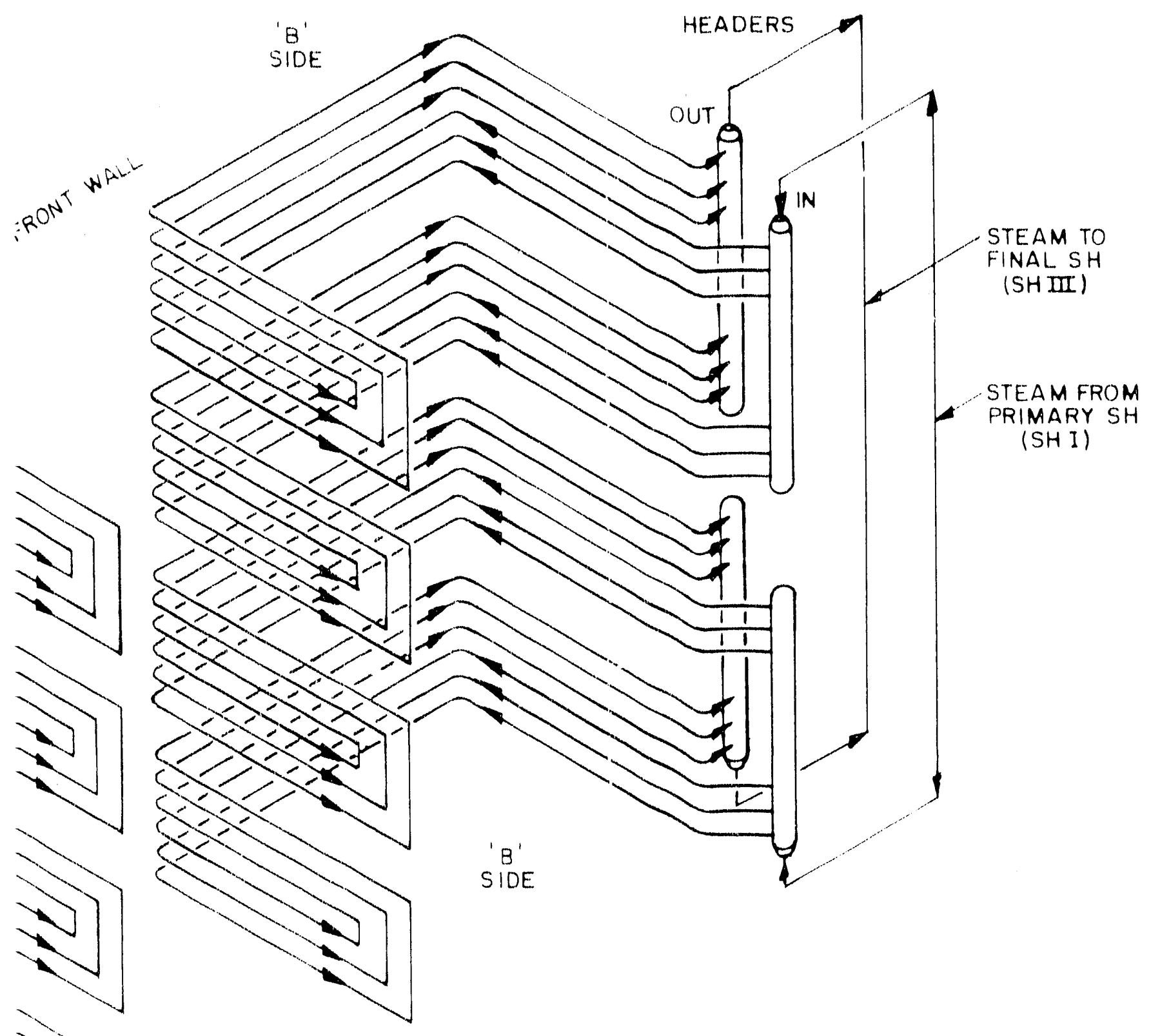

FIGURE 16

21

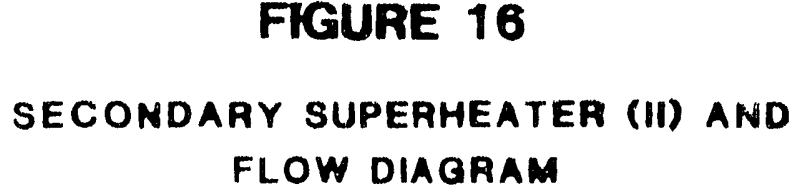

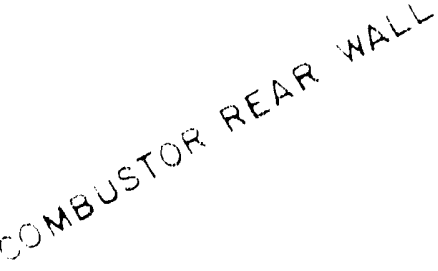


The economizer uses the bare tube horizontal serpentine design arranged in three banks. Economizer inlet and outlet headers are equipped for venting and draining. The economizer inlet feedwater line is equipped with feed-stop and feed-check valves. The economizer outlet tubes (risers) form water-cooled supports for the superheater I (primary SH) and superheater III) final $\mathrm{SH}$ ) tube banks.

Two ash hoppers are located below the economizer to reduce ash deposition inside the tubes of the downstream air heater. Each hopper is an inverted pyramidal shape and has a capacity of approximately 30 tons ( 33 short tons) of fly ash. The economizer is enclosed by steel casing. The economizer casing is fabricated from flanged steel panels, reinforced as required and seal welded at all joints to prevent gas leakage. The casing is insulated and lagged.

\section{1 .5 Sootblowers}

Steam sootblowers are provided to clean the economizer and tubular air heater surfaces. The circulating AFBC boiler is provided with sootblower wall boxes in the primary (SH I) and final (SH III) sections of the convection zone for future sootblower additions, if required at a later date.

A total of 16 steam sootblowers are provided. Twelve fixedposition, lance-type sootblowers are installed in the econorizer, six on each side. Four straight-line retractable sootblowers are installed on the tubular air heater cold section inlet tube sheet. Steam is used as the blowing medium. (The plant compressed air system was not sized for sootblower air requirements or pressures.) Sootblowing steam is provided from the Superheater I outlet steam header and reduced to a pressure of 600 psig.

Originally, sootblowers were not to be provided for the circulating $A F B C$ boiler, but wallboxes for their future installation were provided. Colorado-Ute agreed to add the sootblowers during the construction phase of the project as advised by Pyropower. This decision was based on operating experience with Pyropower industrial circulating AFBC boilers which showed a steady increase in boiler flue gas outlet temperatures when sootblowers were not operated on a regular basis.

\section{1 .6 Boiler Insulation/Lagging/Casing}

The boiler insulation/lagging/casing scope of supply includes boiler components and accessories that protect, insulate, reinforce, and provide access to the air/gas side of the boiler. This includes the combustor and the convection 
sections of the circulating AFBC boller, the baghouses, air and gas ducts, and boiler interconnect piping. Also included are the penthouse casing, penthouse and combustor access openings, combustor refractory, and combustor buckstays in addition to the combustors and penthouse insulation and lagging. The convection section insulation/lagging/casing scope includes access openings, economizer casing, economizer ash hoppers, and convection pass buckstays.

The circulating AFBC boiler is insulated for heat conservation, maintenance of operating temperatures, and protection for personnel. All external surfaces of the boiler are insulated with mineral wool or calcium-silicate insulation, except the recycle system components (hot cyclone collectors, loop seals, and gas flues) which are internally lined and insulated with castable refractory. The boller external surfaces are insulated or refractory lined (recycle system) to prevent the face surface temperature from exceeding $60^{\circ} \mathrm{C}\left(140^{\circ} \mathrm{F}\right)$ based on $27^{\circ} \mathrm{C}\left(80^{\circ} \mathrm{F}\right)$ ambient air temperature and $15 \mathrm{~m} / \mathrm{min}(50 \mathrm{ft} / \mathrm{min})$ air velocity.

The boiler combustor and convection section enclosures are constructed of membrane-type walls so that thermal insulation is limited to mineral fiber covered with ribbed aluminum lagging. The economizer section has an uncooled casing, but it is located in a relatively low-temperature region of the boiler so that thermal insulation requirements were not excessive.

The combustors and convection pass membrane walls are reinforced to withstand the positive and negative boller gas side design pressure of $\pm 102 \mathrm{~cm}( \pm(40 \mathrm{in}) \mathrm{wg}$. This reinforcement includes channel tie bars that are welded to the tube walls with buckstays attached to the tie bars via slip connections. These buckstays are located externally outside the membrane wall insulation.

\subsubsection{Boiler Vents and Drains}

The boiler vents and drains system include all the boiler vent and drain piping, boiler safety valves, and blowdown equipment. The entire system is new.

Boiler vents are provided on the steam drum and on all other boiler pressure part high points including the economizer and superheater sections, as well as on the final superheater outlet connection to the main steam line. Boiler drains are provided at all pressure part low points. Vent and drain down lines are complete with two isolation valves to meet American Society of Mechanical Engineers (ASME) Boiler and Pressure Vessel Code requirements. All vents, including safety valve 
vent stacks, are safely routed to the atmosphere. All boiler drains are routed to the blowdown tank.

Boiler safety valves are provided on the steam drum and final superheater (SH III) outlet header in accordance with ASME Code requirements. Three boiler safety valves are located on the steam drum and one safety valve is located on the final superheater outlet header. Also, an electromatic relief valve is provided, which is included with the main steam system.

The boiler continuous blowdown line is provided with two throttling valves arranged in parallel. The continuous blowdown flow passes through the throttling valves to a blowdown flash tank which recovers blowdown flash steam. Blowdown flash steam is routed to the deaerator and the flash tank blowdown drain flow is routed to either the new Unit 4 circulating water system as makeup (normal flow path) or alternatively to the Unit 4 blowdown tank. The blowdown flash tank is also equipped with a safety valve.

In addition to receiving boller drains and continuous blowdown flows, the blowdown tank also receives turbine drains. Blowdown tank makeup water is supplied from service water, which is regulated to maintain a minimum water level in the tank. Blowdown tank drains flow to a storm drain and to the highquality holding pond.

\subsection{Coal and Limestone Feed Systems}

The circulating AFBC boiler has independent coal- and limestonefeed systems. These systems provide controlled feed of presized coal and limestone from the boiler fuel and sorbent silos to each boiler combustion chamber. The combustion chambers have separate injection ports for coal (three each) and limestone (four each). Coal is fed into each combustion chamber through two front-wall coal injection ports and a rear-wall loop seal leg port. Limestone is fed through two separate front-wall limestone injection ports, a side-wall port, and a rear-wall injection port. The Nucla circulating AFBC boiler and limestone feed systems are airand mechanical-transport types and as shown in Figure 15.

\subsubsection{Circulating AFBC Boiler Coal Feed System}

The circulating AFBC boiler coal feed system provides controlled mechanical feed of prepared coal from the boiler coal silos to the boiler combustion chambers. The system includes gravimetric-feeder equipment and components located between the coal silo outlet connections and the combustion chambers. 
Crushed coal, $6 \mathrm{~mm} \times 0(1 / 4$ in $\times 0)$, flows by gravity from three coal silo pantleg outlet hoppers located on each of the two boiler coal silos. Each coal silo serves one combustion chamber. An elongated silo outlet hopper design enhances coal flow out of these silos. The crushed coal discharges from the si.lo outlet hoppers through $610 \mathrm{~mm}$ (24 in) size, cha!in-wheeloperated, slide-gate isolation valves into gravimetric coal feeders. A total of six gravimetric coal feeders are furnished for the circulating AFBC boiler. Three feeders connect each sal silo to eash combustion chamber. There are three coal teed port locations in each combustion chamber, one per feeder train. Two are located in the front wall and one in the loop seal in the rear wall of each comoustion chamber.

The operating equipment in each of the six coal feed trains consists of the following:

- A feeder inlet isolation slide-gate

- A gravimetric feeder

- A rotary valve

- A combustion chamber motor-actuated isolation gate.

Two of the six coal feed trains, those feeding to the rearwall loop seal feed locations on each combustor, also have horizontal and inclined en-masse conveyors to physically transport the coal from the feeder discharge connection around the combustor to the rear feed port lnated on the loop seal leg. The rotary valves in each coal feed train act as a pressure seal between the pressurized combustion chambers and the coal feed system, which operates at atmospheric pressure.

Each gravimetric coal feeder for each combustion chamber is redundant. The capacity of each combustion chamber feed system is capable of full load. Coal feed system design data are presented in Table 13. It is expected that a reduction in carbon utilization will occur with only one or two feed systems in operation per combustor due to poorer fuel feed distribution. Each gravimetric feeder and rotary valve feeds coal into the combustion chamber through an inclined g? zvity feed chute connected to the combustor or loop-seal, coul-feed port. At each roal-feed port, a plenum box is provided through which secondary air acts as a purge. 
Table 13

COAL FEED SYSTEM DESIGN DATA

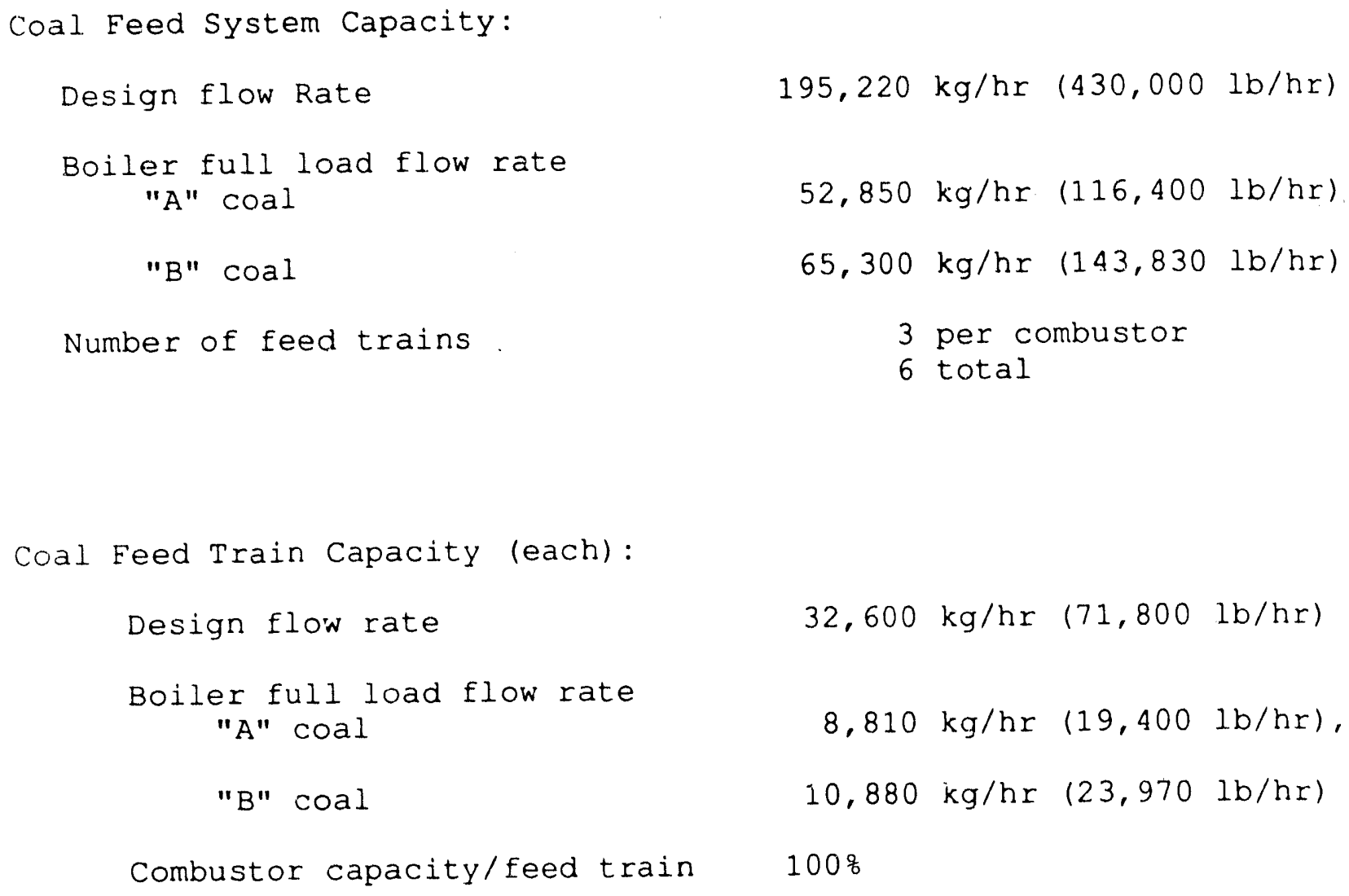


The coal-feed rate is adjusted automatically, as required by the turbine-generator steam demand, and trimmed by boiler pressure. This is accomplished by changing the speed of each gravimetric feeder on a predetermined proportionate basis over the normal boiler load turndown range.

Originally, the loop-seal, coal-feed ports were provided for design flexibility in the event that improvement in actual performance (carbon utilization) should be required at a later date. The boiler manufacturer decided that these feed locations would be required to meet performance guarantees during the construrtion phase of the project. This decision was based on the operating experiences of their industrial circulating $A F B C$ coal-fired boilers. This change was initiated in early 1986 during the early phases of the Nucla boiler construction.

\subsubsection{Circulating AFBC Boiler Limestone Feed System}

The circulating AFBC boiler limestone-feed system provides controlled pneumatic feed of prepared limestone from the boiler limestone silos into the boiler combustion chambers. The system includes all the limestone-feed equipment and components between the limestone silo outlet connections and the combustion chambers.

Pulverized and dried limestone, with an average size of 150 micron (50\% passing 100 mesh screen), flows by gravity from the cone-shaped outlets of each of two limestone silos. Each limestone silo serves one combustion chamber. The premilled limestone discharges from the silo outlet hopper through a piston-actuated, slide-gate isolation valve and chute to a limestone feeder. The two limestone feeders, one fer combustion chamber, are loss-in-weight type gravimetric feeders (i.e., where the rate of feed from a measured feed hopper weight is integrated over a period of time).

Each limestone-feed system utilizes a bin vibrator (located on the bottom of the limestone silo) to promote flow of limestone into the gravimetric feeder charge hopper. When the feeder charge hopper is full, as measured by its weight gain, two or more of the four hopper outlet gates open. A hopper vibrator regulates the flow rate of limestone from the hopper to the feed streams. When the feeder-charge hopper reaches a preset low limit, as measured by weight loss, the charge hopper is then refilled. Thus, the limestone feeder is a "loss-inweight" type gravimetric ferder. The limestone gravimetric feeders are elecironically monitored over a period of time to obtain an integrated rate of limestone feed. The limestone loss-in-weight type gravimetric feeders are each automatically 
adjusted in direct relation to combustion chamber coal flow and trimmed based on combustor/hot cyclone outlet flue gas analysis for $\mathrm{SO}_{2}$.

Each limestone feed stream is admitted to positive pressure pneumatic conveying lines through rotary valves. There are four 50\% capacity limestone feed pneumatic transport trains per combustion chamber. Each train consists of the following major equipment:

- a dedicated positive displacement conveying air blower

- rotary valve

- transport conveying line

- injection gate.

This equipment transports the limestone from the limestone gravimetric feeder to four separate feed points on each combustion chamber. With the exception of the transport line length, all eight trains are identical. Limestone and pneumatic conveying air are injected into the combustion chambers through injection ports, one port per conveying line. Each combustion chamber has two limestone injection ports on the front wall (different from the coal injection ports), one on the side-wall, and one on the rear wall at the loop seal recycle port. The limestone pneumatic conveying injection systems are sized to admit the maximum expected limestone flow quantities through any two of the four injection ports per combustion chamber. Limestone feed system design data are presented in Table 14 .

\subsection{Air and Flue Gas System}

The combustion air and flue gas system provides the combustion air to and removes the flue gas from the circulating AFBC boiler. The system includes the combustion air supply from the primary air (PA) and secondary air (SA) forced-draft fan inlets to the boiler combustion chambers, the boiler gas path, and the means of flue gas removal from the boiler to the stack inlet connection. The major system equipment and components are comprised of the following:

- The PA, SA, and ID fans.

- The water-cooled air distributors and windboxes.

- The combustion air ducts and gas flues. 
Table 14

LIMESTONE FEED SYSTEM DESIGN DATA

Ca/S Molar Ratio:

The recirculating $\mathrm{AFBC}$ boiler guaranteed $\mathrm{SO}_{2}$ emission limit is 0.4 lb/million Btu heat input.

The guaranteed $\mathrm{Ca} / \mathrm{S}$ molar ratio to meet this $\mathrm{SO}_{2}$ emission limit with performance "A" coal is 1.5 .

Limestone Feed System Capacity:

Design or maximum flow rate

$11,350 \mathrm{~kg} / \mathrm{hr}(25,000 \mathrm{lb} / \mathrm{hr})$

Full load boiler flow rate $2007 \mathrm{~kg} / \mathrm{hr}(4420 \mathrm{lb} / \mathrm{hr})$, "A" coal

Limestone Pneumatic Feed Train Capacity (for each of eight):

Design or maximum flow rate

$1419 \mathrm{~kg} / \mathrm{hr}(3125 \mathrm{lb} / \mathrm{hr})$

Full load boiler flow rate

$251 \mathrm{~kg} / \mathrm{hr}(553 \mathrm{lb} / \mathrm{hr}), " \mathrm{~A} "$ coal 
- The air heater, which exchanges heat from the flue gas to the PA and SA combustion air streams.

- The baghouses.

- The stack.

The entire combustion air and flue gas system is new, including new gas flues connecting to and from the existing Unit 1-3 baghouses. The Nucla circulating AFBC boiler and flue gas system is shown schematically in Figures 13 and 15 . Air and fiue s system design performance data are summarized in Table 15.

Combustion air is supplied by centrifugal PA and SA fans. Both $P A$ and $S A$ streams are heated in the tubular air heater before delivery to the combustion chambers. Air preheating or tempering coils are not provided upstream of the tubular air heater for either PA or SA streams.

Primary and secondary combustion air are drawn from the upper area of the boiler building by the PA and $S A$ fans. Individual intake ducts are routed to the PA and SA fans, which are both located at the plant grade elevation. This helps boiler building ventilation, recovers boiler and plant radiation heat losses, and preheats the PA and SA air streams during reasonabl $y$ warm periods. During colder periods, reversible flow, gravity air movers located in the boiler building roof direct outside air (as required) to the $\mathrm{PA}$ and $\mathrm{SA}$ fan inlets, minimizing the impact on the building heating system.

Primary air is supplied below the air distribution grid at the bottom of the combustion chambers. Primary air is also injected into the combustors through lower wall ports located around the periphery of the combustion chambers for bed mixing (lower-level $S A)$, through the rear-wall coal ports, and through the startup burners. A PA duct burner is installed in each PA distributor windbox. The purpose of the PA duct burners is to preheat fluidizing air during boiler startups, thus avoiding bed material cooling before introducing coal to the bed.

Secondary air is supplied to wall ports located axourd the periphery of the combustion chambers at an elevation above the PA wall ports and also to the front-wall coal injection ports. The $\mathrm{SA}$ is injected into the combustor to ensure complete combustion and provide the benefits of staged combustion (i.e., high-combustion efficiency with low $\mathrm{NO}_{x}$ generation). 
Table 15

AIR AND GAS SYSTEM DESIGN PERFORMANCE DATA

Data for Performance Coal "A"

Total Combustion Air Flow:

$459,200 \mathrm{~kg} / \mathrm{hr} \quad(1,011,4001 \mathrm{~b} / \mathrm{hr}$

Excess Air:

$20 \%$

Air Heater Leakage:

$0 \%$

Elue Gas:

Flow

Leaving Combustors

To Baghouses

TO ID Fan
$512,900 \mathrm{~kg} / \mathrm{hr}(1,129,700 \mathrm{lb} / \mathrm{hr})$ $871^{\circ} \mathrm{C} /-0.3 \mathrm{~cm}$ wg $\left(1600^{\circ} \mathrm{F} /-0.1 \mathrm{wg}\right)$

$126^{\circ} \mathrm{C} /-32.5 \mathrm{~cm}$ wg $\left(258^{\circ} \mathrm{F} /-12.8^{\prime \prime} \mathrm{wg}\right)$

$126^{\circ} \mathrm{C} /-60.2 \mathrm{~cm}$ wg $\left(258^{\circ} \mathrm{F} /-23.7^{\prime \prime} \mathrm{wg}\right)$ 
Additional small amounts of combustion air also enter the combustion chambers from the following sources:

- The high-pressure loop seal air blowers as fluidizing air entrained with the hot cyclone solids recycle streams.

- The bottom ash cooling fan through the bottom ash fluidizing coolers.

- Limestone pneumatic feed conveying air.

- Coal injection ports.

The two hot cyclone collectors separate entrained particles from the combustion chamber outlet flue gas streams. The collected particles are recycled through loop seals to the lower section of the combustion chambers. Flue gas from the hot cyclones continues to the common convection zone, imparting heat via convective heat transfer to the final and primary superheaters and to the economizer. After exiting the boiler convection pass economizer outlet, the flue gas passes downward through the tubular air heater tubes imparting heat to the primary and secondary combustion air streams. The flue gas continues to four baghouses arranged in parallel, one new and three existing baghouses, where entrained fly ash particles are removed to meet emission requirements. Ash is also removed directly from the lower bed section of the combustors as bottom or spent bed ash, and from fly ash collection hoppers located beneath the economizer and air heater outlets. From the baghouses, the flue gas is discharged to the stack by a centrifugal ID fan.

\section{3 .1 Draft Fans}

Both the PA and SA forced-draft fans are equipped with a variable-frequency, speed-control drive system to provide energyefficient service at normal and partial load conditions. The $P A$ fan is equipped with backwardly curved inclined airfoil blades and an inlet silencer. The SA fan is equipped with airfoil blades, an inlet silencer, and inlet vanes. The SA fan inlet vanes are used in conjunction with the variablespeed drive to control the fan at low loads.

The PA fan speed is controlled to vary primary air-duct pressure. PA flow to each distribution grid windbox, to each combustion chamber wall windbox, and to each startup burner is controlled by dampers, maintaining proper air-to-fuel ratios. 
The SA fan speed and inlet vanes are controlled to vary secondary air-duct pressure. SA flow to each combustion chamber wall windbox is controlled to maintain proper staging of combustion. $\mathrm{PA}$ and $\mathrm{SA}$ air flows to each combustion chamber are measured by flow meters located upstream of each of the flow control dampers.

The ID fan is also equipped with a variable-frequency control drive system to provide energy efficiency at normal and partial load conditions. The ID fan has backwardly curved inclined airfoil blades. The ID fan speed is controlled to maintain a constant furnace pressure as measured at the gas outlet of each combustion chamber. Fan test block margins were increased from those typically specified for conventional pulverized-coal-combustion technology (after considering use of a tubular type air heater, with little or no leakage) to accommodate the burning of alternative test fuels during EPRI's two-year testing program. Design performance summaries for the Nucla circulating AFBC boiler PA, SA, and ID draft fans are presented in Table 16.

\subsubsection{Water-Cooled Air Distributor and Windbox}

The water-cooled air distributor grids form the bottom of the combustion chambers. Hot primary air at a relatively high pressure enters the air distributor windbox and is passed up through the air grid distributor to fluidize the bed materials. The distributors are of water-cooled membrane construction and are supported from the combustion chamber lower waterwall headers. Each air nozzle is fitted with a nozzle cap. The distributor nozzle caps serve to distribute primary air and prevent bed material from entering the primary air nozzles and windbox. The design of the water-cooled air distributor plate and primary air nozzles is proprietary.

The water-cooled air distributors and lower sections of the combustor sidewalls are protected by refractory. The refractory is a high-density, abrasion-resistant castable material.

A primary air duct burner is installed immediately upstream of each air distributor windbox. The duct burners preheat primary fluidizing i ir during circulating AFBC boiler startups. This preheating prevents cooling the bed material before introducing coal into it. 
Table 16

DRAFT FAN PERFORMANCE SUMMARIES

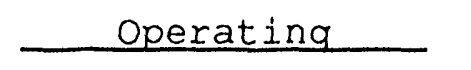

Primary Air Fan 4A

$$
\begin{array}{cc}
336,000 & (740,100) \\
5,822 & (205,600)
\end{array}
$$

Head (static) - cm wg ("wg) $\mathrm{kW}$ (BHP)

Efficiency (static) - 응

Speed - rpm

Inlet Air Temperature - ${ }^{\circ} \mathrm{C}\left({ }^{\circ} \mathrm{F}\right)$

Inlet Silencer Diff Pressure - cm wg ("wg)

\section{Secondary Air Fan 4A}

Capacity $-\mathrm{kg} / \mathrm{hr}(\mathrm{lb} / \mathrm{hr})$
$-\mathrm{m}^{3} / \mathrm{min}(\mathrm{acfm})$
Head (static) $-\mathrm{cm}$ wg ("wg)
$\mathrm{kW}$ (BHP)
Efficiency (static) - $\frac{\circ}{\circ}$
Speed - rpm
Inlet Air Temperature
$\quad-{ }^{\circ} \mathrm{C}\left({ }^{\circ} \mathrm{F}\right)$
Inlet Silencer Diff

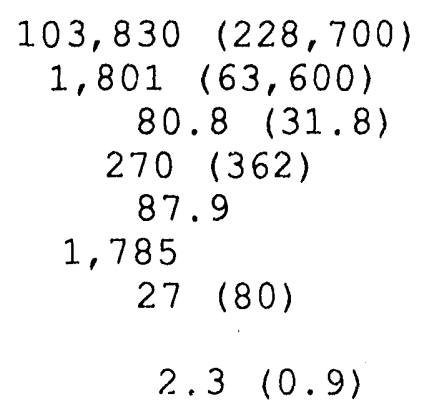

\begin{tabular}{|c|c|c|}
\hline $\begin{aligned} \text { Capacity } & -\mathrm{kg} / \mathrm{hr} \text { (lh ir) } \\
& -\mathrm{m}^{3} / \mathrm{min}(\mathrm{a}, \mathrm{m})\end{aligned}$ & $\begin{array}{l}501,080(1,103,700) \\
11,553(408,000)\end{array}$ & $\begin{array}{l}604,040(1,330,476) \\
14,887(525,730)\end{array}$ \\
\hline $\begin{array}{l}\text { Head (static) } \\
\quad-\mathrm{cm} \text { wg ("wg) }\end{array}$ & $56.1(22.1)$ & $81.0 \quad(31.9)$ \\
\hline $\mathrm{kW} \quad(\mathrm{BHP})$ & $1,231 \quad(1,650)$ & $2,257 \quad(3,025)$ \\
\hline Efficiency (static) - $\frac{q}{6}$ & 86.1 & 87.3 \\
\hline Speed - rpm & 900 & 1,121 \\
\hline $\begin{array}{c}\text { Inlet Static Pressure } \\
-\mathrm{cm} \text { wg ("wg) }\end{array}$ & $-54.4 \quad(-21.4)$ & $-78.5(-30.9)$ \\
\hline $\begin{array}{l}\text { utlet Static Pressure } \\
-\mathrm{cm} \text { wg ("wg) }\end{array}$ & $2.5(0.98)$ & $3.6(1.43)$ \\
\hline $\begin{array}{c}\text { Flue Gas Temperature } \\
-{ }^{\circ} \mathrm{C}\left({ }^{\circ} \mathrm{F}\right)\end{array}$ & $126(258)$ & $149(300)$ \\
\hline
\end{tabular}

\section{Induced Draft Fan 4A}




\subsubsection{Air Ducts and Gas Flues}

The air ducts and gas flues are sized for air/gas velocities not to exceed $1067 \mathrm{~m} / \mathrm{min}(3500 \mathrm{ft} / \mathrm{min})$. Baghouse collector branch flues are sized for lower velocities. The ducts and flues are routed in a way to minimize pressure drops and, in the case of the flue gas breaching, to reduce dust buildup.

To ensure these design objectives, the manufacturer performed a 1/16 scale, three-dimensional baghouse and gas flue model study of the air-heater outlet to ID-fan inlet during the design phase of the project. This was necessary because the three existing baghouses were utilized in conjunction with installation of the new baghouse without being relocated. Consequently, the gas flue arrangement to and from the four baghouses is more complicated than an optimum arrangement otherwise would be. The scale model design testing provided insights into areas of high potential draft loss, dust imbalance, and dust drop-out. These potential problems were minimized by modifications to the model. The full-scale gas flue arrangement replicated the final model design.

The gas flue between the ID fan and stack is designed as a long, straight section to provide a more convenient location for the stack gas monitoring equipment.

Combustion air ducts and gas flues are fabricated from carbon steel pli. $\because$. All ducts and flues are fabricated from carbon steel plate. All ducts and flues are stiffened and reinforced to withstand operating and design pressures. The ducts and flues are of all-welded construction except at connections to dampers, fans, boiler, baghouses, etc. Joints are of the bolted flange type with at least $1 / 2$-in bolts on $7.6 \mathrm{~cm} 13-$ in) centers and gasketing for the intended service. Combustion air ducts and gas flues are furnished with access doors, dampers, flow-measuring elements, and expansion joints, as required.

The air ducts and gas flues are externally insulated with mineral wool and are lagged with ribbed aluminum. Insulation design conditions prevent the lagging face surface temperature from exceeding $60^{\circ} \mathrm{C}\left(140^{\circ} \mathrm{F}\right)$ based on $27^{\circ} \mathrm{C}\left(80^{\circ} \mathrm{F}\right)$ ambient air temperature and $15 \mathrm{~m} / \mathrm{min}(50 \mathrm{ft} / \mathrm{min})$ air velocity.

The PA and SA fan suction ducts that lead from the top of the boiler enclosure to the PA and SA fan inlet silencers are round ducts fabricated from 1/8-in carbon steel plate. Round to rectangilar transition sections connect to the $\mathrm{PA}$ and $\mathrm{SA}$ fan inlet silencers. 
Primary air control dampers are provided to bypass the air heater cold and intermediate temperature sections, to control $P A$ flow to each combustion chamber bottom fluldizing-grid distribution windbox, to control PA flow to each combustion cliamber lower side-wall PA windbox, and to control PA flow to each of the startup burners. The PA fluidizing-grid windbox inlet flow control dampers are located in the main combustion chamber PA supply ducts downstream of airfoil-type fllow elements and upstream of the PA duct burners. Primary air pressure control is achieved by speed variation of the PA fan. Manual PA dampers are provided at each combustor lower sidewall PA port and at each of the two rear-wall loop-seal, coalinjection ports.

Secondary air control dampers are provided on the double inlets to the SA fan which, in conjunction with SA fan variable-speed control, are modulated (only at SA fan minimum speeds) to maintain a constant SA supply pressure to the combustors. Flow control dampers are provided in both the SA ducts to each combustor downstream of the airfoil-type flow elements and downstream of the SA supply takeoffs to the coalinjection ports. The two SA flow control dampers are provided at each combustor SA port and at each of the four front-wall coal injection ports.

The only flue gas dampers provided are the various baghouse compartment isolation dampers, the new baghouse bypass dampers, and a single manually-operated flow control damper (1ocated in the new baghouse inlet flue) to balance flue gas flow between the new and existing baghouses. Flue gas flow and pressure control are achieved by speed variation of the ID fan. The ID fan is modulated to maintain constant furnace pressure as measured at the combustion chamber outlets.

\subsubsection{Tubular Air Heater}

The tubular air heater is comprised of vertical tubes with separate sections (upper hot end and lower cold end) to facilitate cleaning. Flue gas flows inside the tubes and heats both primary and secondary air, which flow over the tubes in multiple passes. The tubular air heater is illustrated schematically in Figure 17.

The manufacturer uses the tubular type of air heater because of the relatively high pressure differentials between the combustion air and flue gas streams. Most of the Ahlstrom Group tubular air heaters employ horizontal tubes with gas flowing over the tubes. Although this usually results both in lower gas and air-side pressure drops and in space savings, 


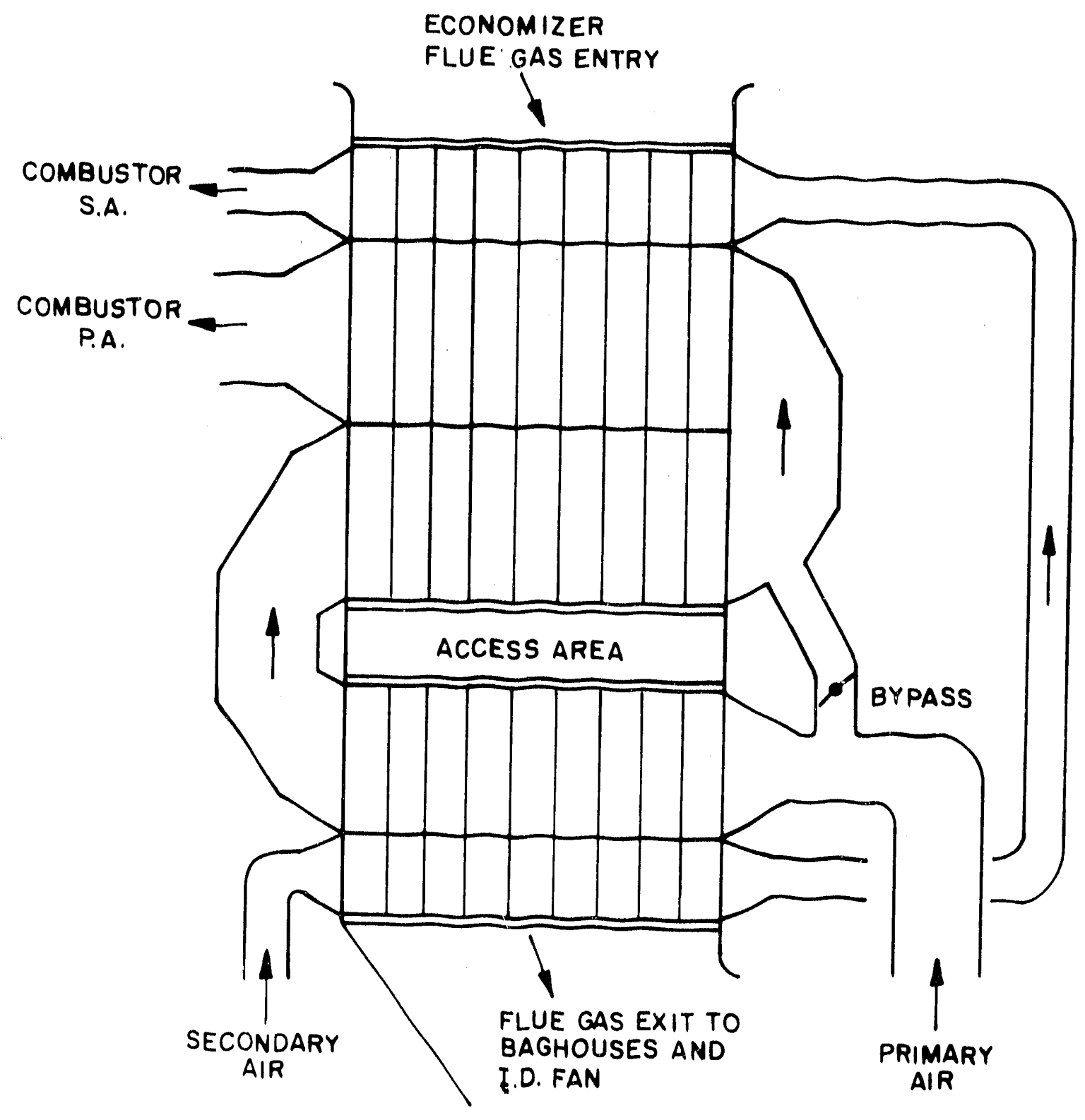

FIGURE 17

TUBULAR AIR HEATER SCHEMATIC 
Colorado-Ute requested the vertical-tube design with the flue gas flowing downward inside the tubes to facilitate space savings, cleaning and maintenance.

Flue gas from the boiler economizer outlet enters the top of the air heater and flows downward inside vertically arranged tubes in a single pass through the upper hot end followed by passage through the lower cold-end section. Primary and secondary air streams pass horizontally over the tubes in a multipass crossflow arrangement. Primary air is arranged for three passes, one across the lower cold-end section and two across the upper hot-end section. Secondary air is arranged for two passes, one across the lower cold-end section and one across the upper hot-end section.

The air heater is enclosed by an uncooled casing. The casing is fabricated from flanged steel panels, reinforced as required to withstand maximum PA and SA pressures, and seal. welded at all joints to prevent air and gas leakage. The casting is externally insulated with mineral wool and is lagged with ribbed aluminurn. Insulation design conditions are to prevent the lagging face surface temperature from exceeding $60^{\circ} \mathrm{C}\left(140^{\circ} \mathrm{F}\right)$ based on $27^{\circ} \mathrm{C}\left(80^{\circ} \mathrm{F}\right)$ ambient air temperature and $15 \mathrm{~m} / \mathrm{min}(60 \mathrm{ft} / \mathrm{min})$ air velocity. Two ash hoppers are 10cated beneath the air heater at the lilue gas outlet. The ash hoppers are pyramidal in shape with a capacity of approximately 36 tons (40 short tons) of fly ash each when half full.

The air heater is sized to result in flue gas outlet temperature of $126^{\circ} \mathrm{C}\left(258^{\circ} \mathrm{F}\right)$ at boiler MCR with $27^{\circ} \mathrm{C}\left(80^{\circ} \mathrm{F}\right)$ ambient $\mathrm{PA}$ and $\mathrm{SA}$ combustion air inlet temperatures. This temperature was lowered from the originally specified $132^{\circ} \mathrm{C}\left(270^{\circ} \mathrm{F}\right)$ early during the design phase of the project. This change was instituted by Colorado-Ute because the present-worth savings of boiler efficiency gain ( $0.3 \%$ ) exceeded the added cost for the additional heat transfer surface area of the air heater. The Nucla circulating AFBC boiler tubular air heater design performance is summarized in Table 17.

The $\mathrm{SO}_{3}$ dew point and its impact on air heater cold-end corrosion is predicted to be negligible because the boiler is warmed up by firing propane before admitting coal to the fluiciized bed. Also, sulfur capture during coal-firing occurs in the combustors upstream of the air heater. Water dew point is the cold-end temperature limit. 
Table 17

AIR HEATER PERFORMANCE SUMMARY

Flue Gas:

Flow

Inlet/out let temperature

Pressure drop

Primary Air:

Flow

Inlet/out let temperature

Pressure drop

Leakage

Secondary Air:

Flow

Inlet/outlet temperature

Pressire drop

Leakage
$501,080 \mathrm{~kg} / \mathrm{hr}(1,103,700 \mathrm{lb} / \mathrm{hr})$

$258 / 126^{\circ} \mathrm{C} \quad\left(496^{\circ} / 258^{\circ} \mathrm{F}\right)$

$9.7 \mathrm{~cm} \mathrm{wg} \mathrm{(3.8"} \mathrm{wg)}$
$103,830 \mathrm{~kg} / \mathrm{hr}(2.28,700 \mathrm{lb} / \mathrm{hr})$

$27 / 184^{\circ} \mathrm{C}\left(80^{\circ} / 363^{\circ} \mathrm{F}\right)$

$6.9 \mathrm{~cm} \mathrm{wg}(2.7 " \mathrm{wg})$

$0 \mathrm{~kg} / \mathrm{hr}(0 \mathrm{lb} / \mathrm{hr})$ 


\subsubsection{Baghouses}

The baghouse system provides for the removal of fly ash from the circulating AFBC boiler exhaust flue gas stream to meet particulate emission requirements. The baghouse system includes the three existing (Units 1-3) baghouse collectors and a new (Unit 4) baghouse collector. All baghouses are connected in parallel to remove particulates from the new circulating $A F B C$ boiler exhaust flue gas stream.

\subsubsection{Existing Baghouses 1-3}

Each of the now retired Unit 1-3 stoker-fired boilers were served by one of three identical baghouses. These fabric filters were retrofitted to the original plant in 1973. These uni.ts were the first to be installed by the electric power industry. in the United States, successfully demonstrating fabric filter particulate control technology in the early 1970s. The existing baghouses have been incorporated into the flue gas cleanup system servicing the new circulating AFBC boiler.

Together, the three existing baghouse collectors provide approximately $48 \%$ of the required treatment capacity at a net cperating air-to-cloth ratio of 2.7 to 1 . Each of the three existing baghouses consists of six individual compartments. The baghouses use the shade-and-deflate cleaning-type design approach.

Each of the three existing baghouses includes six compartments, six fly ash hoppers, six bag shakers, 12 hopper heaters, 672 fiberglass bags, one repressurization (deflation air) fan to assist in bag cleaning, a duct heater for use with reverse air fan during startup, and one inlet/outlet reverse air manifold set. The existing baghouse ash hoppers are electrically heated and are capab:e of storing approximately a six-hour accumulation of fly ash when burning high-ash "B"-type coal. The existing baghouses have no bypass system and no ventilation system.

\subsubsection{New Baghouse 4A}

The new baghouse is provided to augment the capacity of the existing baghouses. The new baghouse provides approximately $52 \frac{z}{z}$ of the required treatment capacity and uses shake-and-deflate cleaning. The unit consists of 12 individual compartments erected in modules. The housing is of 3/16-in thick carbon steel plate. The plan area for the new baghouse is approximately $25 \mathrm{~m} \times 11 \mathrm{~m} \times 14 \mathrm{~m}, 82$

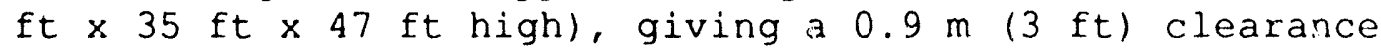


below the hopper discharge flanges. The baghouse is arranged so that any one or more of the compartments may be isolated from service for maintenance at any time. Each new baghouse module has three access doors, one at the tubesheet level, one at the bag support level, and one in the ash hopper. Thermal expansion is accommodated using sliding connections. The new baghouse is externally insulated with $9 \mathrm{~cm}(3-1 / 2-i n)$ of mineral wool and covered with aluminum lagging. Insulation design conditions are to prevent the lagging face surface temperature from exceeding $60^{\circ} \mathrm{C}\left(140^{\circ} \mathrm{F}\right)$ based on $27^{\circ} \mathrm{C}\left(80^{\circ} \mathrm{F}\right)$ ambient air temperature and $15 \mathrm{~m} / \mathrm{min}(50 \mathrm{ft} / \mathrm{min})$ air velocity.

A baghouse internal bypass duct with three poppet-type bypass dampers functions automatically in response to excessive or low baghouse flue gas inlet temperature. These dampers can also be operated manually, such as during startup to avoid temperatures below the flue gas acid dew point. The bypass dampers are located on the division plate between the inlet and outlet gas plenums within Baghouse $4 \mathrm{~A}$. Interlocks are provided to prevent operation of the bypass in parallel with the baghouse. The bypass flue gas flow experiences approximately the same pressure drop as the baghouse. The bypass is sized to pass full boiler gas flow.

The baghouse ash hoppers are fabricated from 3/16-in plate carbon steel and are pyramidal in shape with a minimum $55^{\circ}$ corner slope. The ash hoppers are capable of storing an eight-hour accumulation of fly ash when burning high-ash, "B"-type coal. The ash hoppers are electrically heated to maintain a wall temperature of $93^{\circ} \mathrm{C}\left(200^{\circ} \mathrm{F}\right)$ with a $-29^{\circ} \mathrm{C}$ $\left(-20^{\circ} \mathrm{F}\right)$ ambient temperature.

The bag-cleaning cycle is initiated by a predetermined pressure drop and indexed through all compartments by automatic controls. The controller automatically regulates the cleaning of each compartment in sequence. A deflation air fan is provided to help clean the filter bags with a low-velocity purge. In addition to gentle purging of each bag, there is a motor-driven shaker drive mechanism in each compartment. Any off-line compartment is bypassed during the cleaning cycle. A compartment ventilation system is provided to cool and ventilate any compartment that is out of service for maintenance.

\section{$2.3 .6 \underline{\text { Stack }}$}

The stack provides for the safe dijpersion of circulating AFBC boiler flue gas to the atmosphere. A new stack and stack 
accessories were provided for Unit 4. The existing Unit 1-3 stacks were dismantled and removed from the site.

The Unit 4 stack is an all-welded, self-sxpporting, singlewall steel column. The stack height is $65.5 \mathrm{~m}(215 \mathrm{ft})$ from its foundation. The bottom $15 \mathrm{~m}(48 \mathrm{ft}) 0:$ the stack are tapered from the base ring diameter to the stack diameter. Above the bottom $15 \mathrm{~m}$ the stack is a uniform cylinder. Stack accessories include the following:

- Inlet flanged breaching connection

- Base metal drain collection plate

- Base access manholes

- Lightning protection.

Other than a shop primer, the stack is unpainted. The stack scope of supply does not include the following accessories typically included with power plant stacks:

- High-intensity aircraft warning lights per FAA coda (because stack height does not exceed the height of the surrounding valley walls)

- Ladder

- Sample ports (because stack gas sampling/monitoring is provided upstream of the stack)

- Platforms

- Manhoist or elevator

- Insulation

- Painter's trolley and ring.

\subsection{Solidis Separation and Recycle System}

The solids separation and recycle system captures and recycles the unreacted coal and limestone along with bed ash particles from the outlet flue gas stream back to the lower bed zone of each combustion chamber. This recycle allows the coal and limestone to fully complate their reactions, improving combustion and sulfur capture efficiencies. The principal components of the recycle system are the following: 
- hot cyclone separators

- loop seals

- high-pressure look seal blowers.

The entire recycle system is an integral part of the circulating $A F B C$ boiler. A hot cyclone and loop seal recycle circuit is provided for each of the two combustion chambers.

The hot cyclones separate entrained bed particles of coal ash, calcium sulfate, unburned coal, and limestone (calcined and unreacted, if any) from the flue gas. Flue gas, free of the larger particles, exits the top of the hot cyclones and continues on to the common convection section of the circulating AFBC boiler. The separated bed particles drop to the bottom of the cyclones and enter the loop seals. These loop seals serve to seal the recycle circuit from the significant pressure differential that exists between the bottom zone of the combustion chambers and the hot cyclones by maintaining a vertical head of recycle particles. High-pressure loop seal air is admitted to the bottom of the loop seals to fluidize the recycle particles and return them to the combustion chambers. The high-pressure loop seal fluidizing air is supplied by two common 100\%-capacity, high-pressure air blowers, one operating and backup or spare.

The hot cyclones and loop seals are fabricated from carbon steel plate and are internally covered with $30 \mathrm{~cm}(12 \mathrm{in})$ of refractory to protect them from particle erosion and high temperatures. Abrasion-resistant refractory is installed on top of insulating refractory.

\section{4 .1 Hot Cyclones}

The hot cyclone collectors are fabricated with gussets, supports and access openings. The hot cyclones are each $7 \mathrm{~m}(23$ ft) wide by $16 \mathrm{~m}(54 \mathrm{ft})$ high. The cyclone total wall thickness is approximately $30 \mathrm{~cm}(12 \mathrm{in})$ including refractory. The hot cyclone collectors are supported at the tcp of the cone section from structural steel extending upward Eron grade level.

\section{4 .2 Loop Seals}

Two non-mechanical loop seals, one per combustor and hot cyclone, recirculate cyclone solids back to the combustion chambers. The loop seals are fabricated from carbon steel complete with gussets, supports, and access openings. The loop seals are lined on the inside with two layers of refractory. Total wall thickness is $30 \mathrm{~cm}$ (12 in) including refrastory. 
The loop seals are supported from the hot cyclones and are connected to the combustion chamber rear-wall recycle ports with expansion joints. Fluidizing air ports are located at the bottom of the loop seal to recycle the solids back to the lower section of the combustion chamber through a rear-wall recycle injection port. The design of the loop seals is proprietary.

\subsubsection{Expansion Joints}

Special high-temperature expansion joints are provided at the following locations:

- The inlet to each hot cyclone collector.

- The hot gas duct connections to the convection cage.

- The connections between the loop seals and the combustion chamber recycle ports.

High-temperature expansion joints are required at these locations to accommodite gas/solids temperatures of approximately $871^{\circ} \mathrm{C}\left(1600^{\circ} \mathrm{F}\right)$ and to allow for the differential expansion between the bottom-supported hot cyclones and loop seals, and the top-supported combustion chambers and convection cage section of the circulating AFBC boiler. These special boiler expansion joints are fabric-type and are internally lined with abrasion-resistant and insulating refractory. The loop seal expansion joints are continuously purged with primary air.

\subsubsection{Refractory}

Refractory linings are provided for the following:

- Crossover ducts between combustion chamber and hot cyclone collectors.

- High-temperature cyclone collectors.

- Crossover and transition ducts between each hot cyclone and the convection section.

- Non-mechanical loop seals.

- Special high-temperature expansion joints.

- Fluidizing grid. 
- Lower combustor walls.

- The duct burner flame impingement zone of the primary air distributor windbox.

The linings in the hot cyclones, crossover ducts, and the loop seals consist of two layers of castable refractory. The inner layer, which is in direct contact with bed material, is a high-density, abrasion-resistant castable refractory, and the outer layer is a low-density insulating castable refractory. Both layers of refractory are approximately $15 \mathrm{~cm}(6 \mathrm{in})$ thick. "Y"-shaped anchors hold the castable refractory in place.

\section{4 .5 High-Pressure Blowers}

Two common 100\%-capacity, high-pressure centrifugal loop seal blowers, one operating and one backup spare, supply fluidizing air to the loop seals. These blowers also supply high-pressure elutriating air to drain the bed material to the bottom ash coolers. The loop seal blowers operate at constant speed and are each driven by an induction motor. Loop seal fluidizing air flow control is achiever with blower inlet control vanes. These vanes are set by the operator to maintain constant loop seal air supply pressure. Each blower is equipped with a discharge check and an isolation damper. Manual valves are provided in the fluidizing air lines to each loop seal.

\subsection{Boiler Startup system}

The boiler startup system includes the combustion chamber startup burners and the primary air duct burners and accessories. The system includes the fuel gas (propane) piping, including a single supply connection within the bciler buildinç, plus the valves, burners, and burner management system. The entire system is integral with the circulating AFBC boiler. Vaporized propane is used for plant fuel gas.

Combustor startup burners and primary air duct burners are provided to heat the fluidized bed material to ignition temperature, approximately $500^{\circ} \mathrm{C}\left(900-950^{\circ} \mathrm{F}\right)$, before coal and limestone are introduced. An additional purpose of the primary air duct burners is to preheat primary air to approximately $454^{\circ} \mathrm{C}\left(850^{\circ} \mathrm{F}\right)$ in order to avoid ccoling of the bed material during startup procedures.

Six startup burners are located in each of the outer walls in the lower zone of the combustion chambers and are capable of raising the fluidized-bed temperature to as high as $760^{\circ} \mathrm{C}\left(1400^{\circ} \mathrm{F}\right)$. Each 
startup burner has a heating capacity of $54 \times 10^{9} \mathrm{~J} / \mathrm{hr}(51.2 \mathrm{mil}-$ lion Btu/hr). Together, the startup burners have a total capacity of $324 \times 10^{9} \mathrm{~J} / \mathrm{hr}(307.2 \mathrm{million} \mathrm{Btu} / \mathrm{hr})$, equivalent to about $27 \%$ of rated boiler heat input.

Primary air temperature is raised to approximately $454^{\circ} \mathrm{C}\left(850^{\circ} \mathrm{F}\right)$ with two propane duct burners, which are located in each combustion chamber primary air inlet plenum. Each duct burner has a heating capacity of $46 \times 10^{9} \mathrm{~J} / \mathrm{hr}(44.0 \mathrm{million} \mathrm{Btu} / \mathrm{hr})$.

Each startup and duct burner is provided complete with an igniter, flame failure and supervisory system, instrumented gas trim valve rack with electrical enclosure, windbox, and local burner control. A common boiler master gas trip, isolation and system supply pressure control valve are provided as part of the systern. In addition, a rack-mounted, pressure-reducing station is provided for each group of three startup burners per combustor and for the duct burners. Each of these three rack-mounted, pressure-reducing stations includes a regulator, relief valve, and modulating control valve plus other inherent design valves.

A burner management system provides remote (co trol room) burner control, purge control, indication, detection, safety shutdown, and annunciation of burner system malfunctions.

\subsection{Boiler Instrumentation and Controls}

The boiler instrumentation and control equipment includes only new instruments and controls provided with the circulating AFBC boiler by the boiler supplier. These were limited to hot cyclone outlet $\mathrm{O}_{2}$ and $\mathrm{SO}_{2}$ flue gas analyzers and boiler thermocouples. Instruments and controls provided as part of the boiler startup and duct burner management system are included in the previous section on the boiler startup system. All plant instruments and controls provided by others are included in section $A$ under "Balance-of-Plant Mechanical Equipment and systems."

The following material provides the preliminary startup and normal operating procedures for the Nucla circulating AFBC system.

\section{6 .1 Starting Up}

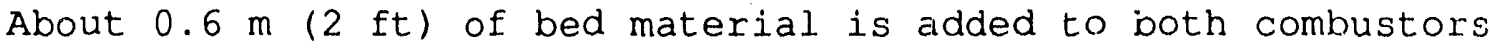
if they are empty. The boiler fans are started in the following order:

1. Induced draft fan

2. A high-pressure (loop seal) blower 


\section{Secondary air fan \\ 4. Primary air fan.}

The primary air is adjusted to give an even fluidization in both combustors. The air flow is adjusted to a minimum flow. The main interlocks are checked. It is necessary to perform a furnace (combustor) air purge before inserting any startup burner or igniting any duct burner if the bed temperature is less than $760^{\circ} \mathrm{C}\left(1400^{\circ} \mathrm{F}\right)$. It is not necessary to purge the combustors before introducing coal if the bed temperature is above $760^{\circ} \mathrm{C}\left(1400^{\circ} \mathrm{F}\right)$.

The firing is adjusted to warm up the bed maicerial. The bed material is used to warm the refractory in the combustors and the cyclones slowly enough to avoid cracking. The fluidizing (primary) air temperature is raised slowly up to $454^{\circ} \mathrm{C}$ $\left(850^{\circ} \mathrm{F}\right)$. (This is the temperature limit set during the initial startup period.) Secondary air flow is adjusted to meet changes in fuel flow

The warm-up time is limited so that the refractory temperature, as ineasured by thermocouples, rise does not exceed 50 to $56^{\circ} \mathrm{C}\left(90\right.$ to $\left.100^{\circ} \mathrm{F}\right)$ per hour from cold start to about $316^{\circ} \mathrm{C}$ $\left(600^{\circ} \mathrm{F}\right)$. After that period, the refractory can be warmed at about $72^{\circ} \mathrm{C}\left(130^{\circ} \mathrm{F}\right)$ per hour. When the refractory temperature has reached about $593^{\circ} \mathrm{C}\left(1.100^{\circ} \mathrm{F}\right)$, the refractory no longer limits the warm-up timing.

During the boiler warm-up, the coal-feed system is checked and started so that some coal ( 30 seconds at minimum feed) can be fed into the combustors when $482^{\circ} \mathrm{C}\left(900^{\circ} \mathrm{F}\right)$ bed temperature is reached. (This is the temperature at which the Nucla coal was observed to begin burning during the initial startup period.) The ignition of the coal is confirmed by the temperature rise. If, after adding another small dose of coal, the temperature continues to rise, a continuous coal feed is commenced and startup fuel firing rate is decreased. The coal-feed rate is slowly increased while the bed temperature is observed. When the bed temperature reaches $760^{\circ} \mathrm{C}\left(1400^{\circ} \mathrm{F}\right)$, all startup fuel firing is cut off. During the startup, the oxygen level in the flue gas streams is kept above $5 \%$.

The ash coolers and the ash-cooler fan are started. The pressure drop in the bed is checked and bed material is added if it is too low. The limestone-feed system is also started. If the unit is started from warm conditions, the same procedures, in principal, are followed. 
As the startup procedure continues, some control circuits (such as the furnace pressure control, secondary air pressure, drum level, and bed pressure/ash coolers controls) are switched to automatic operation. After the turbine is started, the remaining hand-operated controls (such as the combustion control, secondary air upper/lower level ratio control, and superheater temperature control) are switched to automatic operation.

\subsubsection{Normal Operation}

When stable firing conditions are reached, the boiler load is increased to the desired level on automatic control. Because of the twin-combustor arrangement, the fiel and ail feed and the ash removal are controlled separately to load both combustors to nearly identical operating condition.

\subsubsection{Drum Level/Feedwater Control}

The drum level/feedwater control is the standard threcelement type, with feedwater flow controlled by a comparison of steam and feedwater flows, and then trimmed by drum level.

\subsubsection{Draft Controller}

The draft controller adjusts the ID fan to keep about $0.6 \mathrm{~cm}(-1 / 4 \mathrm{in}) \mathrm{wg}$ draft in the upper part of the conbustors.

\subsubsection{Combustion Control/Load Control}

The combustion air flow and coal feed are controlled in accordarice with the steam pressure/steam flow measurements. The coal flow is measured to both furnaces seriarately. The feed rate is controlled by feeder speed.

Because of the twin combustor arrangement, the combustion control data for both furnaces are continuously compared and kept within certain tolerances.

Limestone feed follows the fuel feed and is trinmed in accordance with flue ga.s $\mathrm{SO}_{2}$ analyzer readirigs.

\subsubsection{Combustion Air Control}

The primary air is always kept over minimum fluidizing level and foilows its programmed air/fuel flow curve. The secondary air is programmed similarly, observing the ash 
cooler air flow (which is considered secondary air entering the combustors). The programmed secondary air flow setting is trimmed by the flue gas oxygen analyzer readings. The ratio of upper and lower secondary air is controlled by the bed temperature controller, which keeps the total amount unchanged.

Air solenoid valves are used on a periodic basis to allow air from the high-pressure blowers to convey bed material from the combustors into the ash-fluidizing cooler/classifiers via fluidizing spider pipes. The ash cooler/classifiers are fluidized with air from the ash-cooling fan. Rotary valves are used to let downcooled and classified bottom ash from the ash coolers to the bottom ash conveying system. The speed of the rotary valves is controlled manually by the operator based on combustor differential bed preusure.

\subsubsection{Master Fuel Trip}

A master fuel trip is caused by any of the following conditions:

- A decrease of bed temperature to less than $649^{\circ} \mathrm{C}\left(1200^{\circ} \mathrm{F}\right)$ if a coal reeder is running without a startup burner in. service and the temperature has been absve $760^{\circ} \mathrm{C}\left(1400^{\circ} \mathrm{F}\right)$.

- Low primary air windbox pressure in either combustor.

- A turbine trip.

- Drum level greater than maximum.

- Drum level less than minimum for more than 10 seconds.

- High combustor pressire.

- Operator energency stop.

- All coal feeders from one combustor trip while one or two feeders from the other combustor are still on.

A master fuel trip command results in:

- A loss of the main interlocks, which will trip coal feeders, startup burners, duct burrers, main propane shutoff valve, and limestone feeders.

- Reduction of PA flow to minimum. 
- Reduction of SA flow to minimum.

- Reduction of ash cooling fan pressure to minimum.

\section{6 .4 Shut Down}

The unit load is reduced to minimum. The main controls are turned to manual position and fuel feed is stopped. The bed is cooled down by air. When the bed temperature reaches $400^{\circ} \mathrm{C}$ $\left(750^{\circ} \mathrm{F}\right)$, the fans can be stopped in the following order:

1. SA fan

2. $P A$ fan

3. High-pressure blower

4. ID fan.

If a fast cooling is necessary or the unit is shut down for repairs or inspection, the bed material is removed through the ash coolers. 


\section{Section III. Material Handling Systems}

There are separate material handling systems for coal, limestone, and ash. The coal- and lirnestone-handling systems include truck unloading, transfer, preparation, and the storage of coal and limestone. These systems interface with the circulating AFBC boiler coal and limestone feed systems at the coal and limestone silo outlet connections. The ash-handling system interfaces with the circulating AFBC boiler and baghouses at the combustor bottom ash drain ports and at the economizer, air heater, and baghouse fly ash hopper discharge connections. The ash-handling system includes all ash let down, cooling, transfer, storage, preparation, and truck loading of the bottom and fly ash. The ash handling system als? provides for transfer of stored bottom ash back to the combustion chambers. This ash is used to charge the circulating AFBC boiler fluidized beds with inert spent bed ash, as required, prior to boiler startups. Materjal hand'ing systems equipment data is included in Appendices $A$ and $B$.

\subsection{Coal Handling System}

The coal-handing system provides for receiving, transferring, storing, and preparing the coal before it is fed into the circulating $\mathrm{AFBC}$ boiler combustion chambers. The system includes all coal handling equipment from the truck receiving hopper to, and including, the boiler coal silos. The system is comprised of a combination of both existing and new equipment items. A flow diagram of the plant coal-handling system is presented in Eigu. 18.

The existing lucla station coal-handling system provides for coal receiving, two stages of crushing, sampling, ready storage/reclaim, and transfer into the plant building. The existing coal-handling system is designed for 114 tons/hr (125 short tons/hr) continuous capacity.

New equipment installed with the circulating AFEC boiler provides for transferring the coal from the existing plant conveyor to a surge bin and crushing the coal to $6 \mathrm{~mm} x 0(1 / 4$ in $x 0)$ size; the crushed coal is then transferred to the two coal silos. Two new independent coal-handling trains are provided for this purpose. Each new coal-handling train has a continuous capacity of 68 tons/hr (75 short tons/hr), which is the maximum capacity of the crusher.

Raw, run-of-mine coal is delivered from local coal mine(s) to the plant by over-the-road trucks and dumped into an unloading hopper. The existing truck scale is used to weigh the coal trucks before unloading. Two half-capacity vibrating feeders deliver coal from the unloading hopper to the primary crusher. 


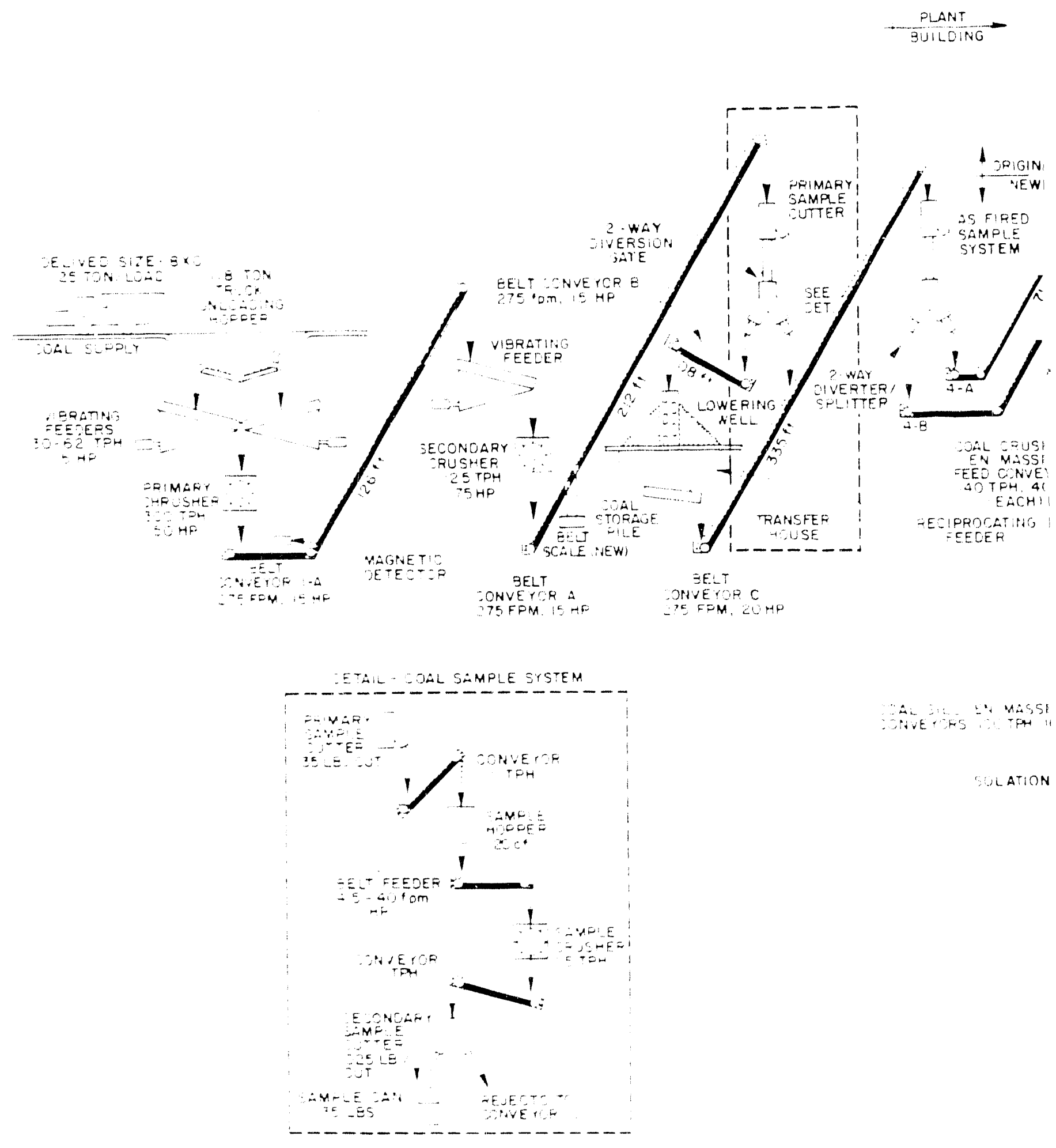



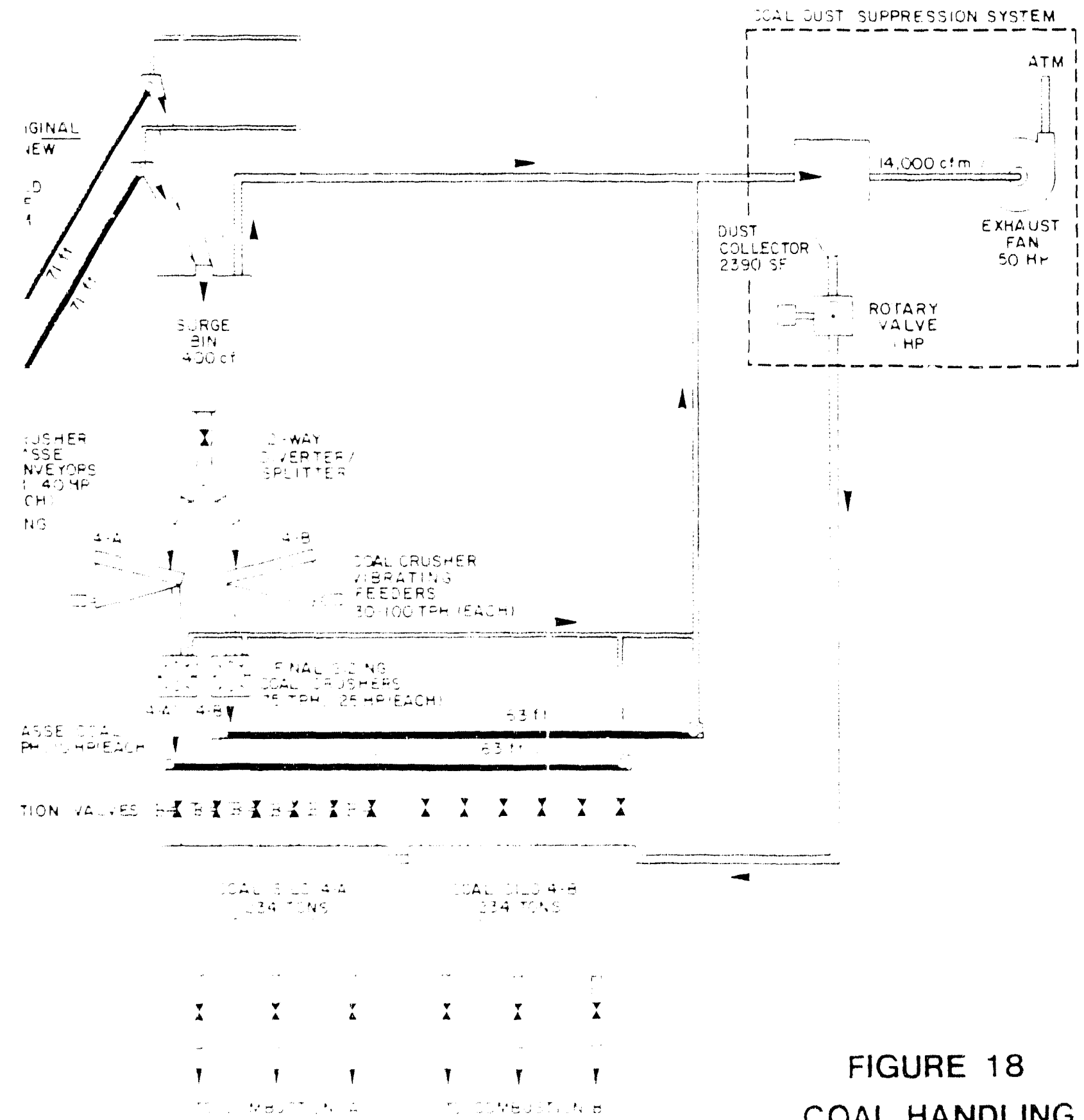

FIGURE 18

COAL HANDLING

FLOW/ DIAGRAM 


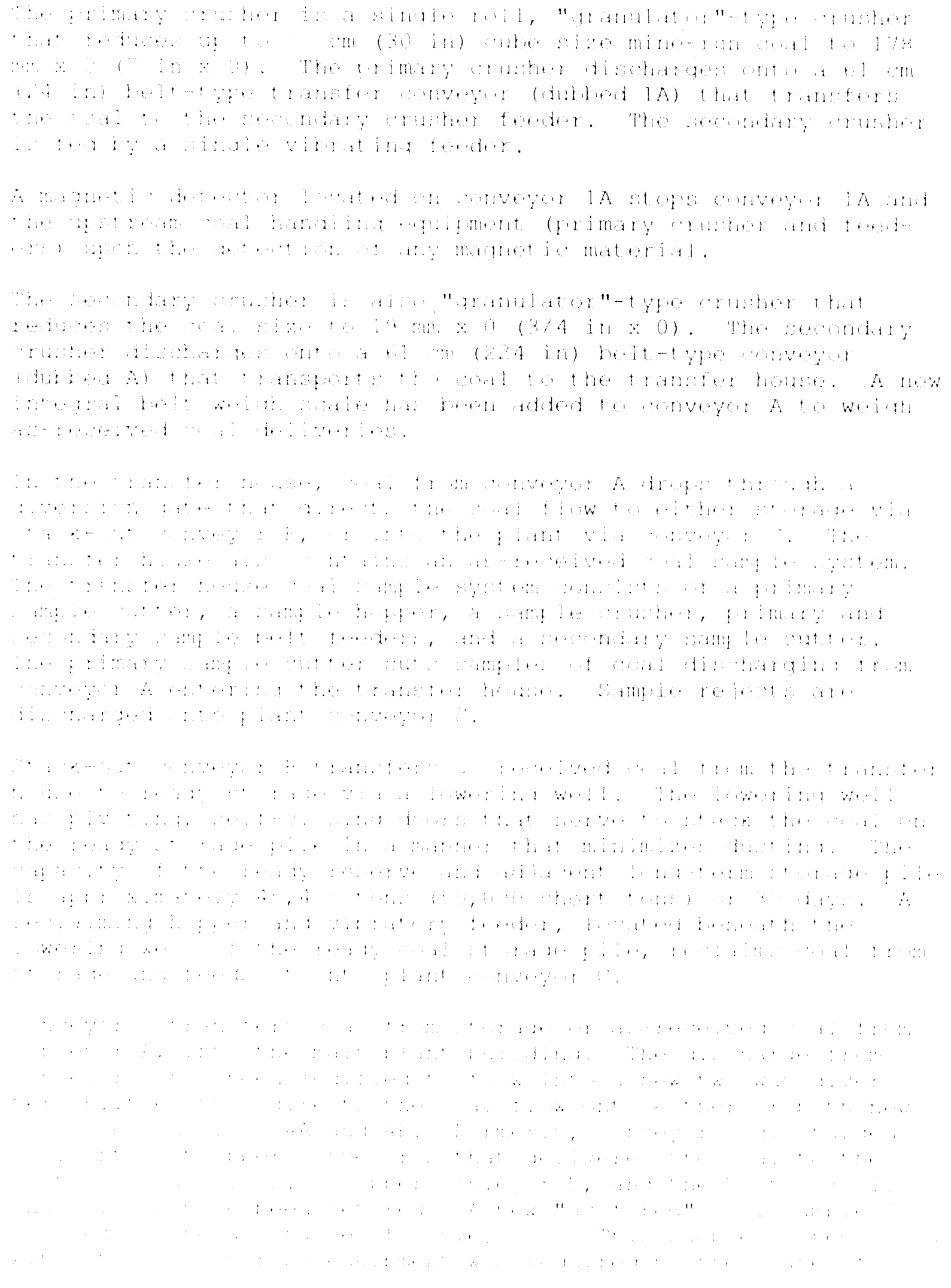


Coloradio to continuously monitor $\mathrm{SO}_{2}$ capture and other emissions for comparison to sample analysis.

In the event of equipment problems downstream of conveyor $C$, it. was deemed desirabıe to have the capability to unlcac plant conveyor C. Accordingly, an 18-ton (20 short ton; surge hopper with capacity to store all coal from the reclaim feed point of conveyor $\mathrm{C}$ is provided above the final sizing crushers. The addition of the surge hopper above the crushers required coal to be elevated to $12 \mathrm{~m}$ (40 ft) above tre existing discharge of conveyor $C$. Due to the vulnerability of this existing conveyor, it was decided to install two $432 \mathrm{~mm}(17-i \mathrm{n})$ wide chain-type, enmasse coal crusher feed conveyors $4 \mathrm{~A}$ and $4 \mathrm{~B}$, each capabie of handling the full capacity of conveyor $C$. These conveyors ift the coal into the surge hopper and are rated at 127 tons/hr (140 short tons/hr) each. The naw en-masse conveyors are designed to operate at a chain speed below $30 \mathrm{~m} / \mathrm{min}(100 \mathrm{ft} / \mathrm{min}$ ).

Two reversible impact crushers, each sized for continuous feed of $38 \mathrm{~mm} \times 0(1-1 / 2$ in $x 0)$ coal at a rate of 65 ton:/hr $(72$ short tons/hr) reduce the final coal sizing to $6 \mathrm{~mm} \times 0(1.4 \mathrm{in} \times 0)$ required to feed the circulating AFBC boiler combustion chambers. Both crushers operate simultaneously tc accept the full ouiput of plant conveyor C. A two-way splitter/divertar and two $76 \mathrm{~cm}$ (30in) wide vibratory feeders at the surge hopper discharge permit une or both cruahers to be operater. In the event that one crusher is disabled, two courses of action are available. If it is anticipated that the crusher wili be out of service for a short time, one crusher can be run delivering $130 \%$ of full-load coal requirement for the higher-heating value "A"-type coal or $100 \%$ full-load coal requirement for the lower-hating value "B"type coal. If the crusher will be out of service for an extended length of time, the operating crusher can be readjusted to a larger-sized [13 $\mathrm{mm} \times 0(1 / 2$ in $\mathrm{x} 0)]$ product, which will enable it to deliver 91 tons/hr (100 short tons/hr). A slight boiler efficiency decrease may occur as a result of increased coal feed sizing. This will also limit coal loading to approximately 16 hours per day with the plant at full lodd.

Two $33 \mathrm{~cm} \times 16 \mathrm{~m}$ (13 in $\mathrm{x} 54 \mathrm{ft}$ ) long horizontal chain-type, enmasse silo feed conveyors transfer the full output of each crusher to either or both of the two boiler coal silos. Three feed points are provided from each conveyor at the top of each silo to obtain a high percentage fill. The inlet openings to coal silo $4 \mathrm{~A}$ are equipped with remotely-operated slide gates so that this silo can be bypassed to feed coal to silo 4B. Coal silo 4B is equipped with manual slide gates for silo maintenance.

Two cylindrical coal silos, $4 \mathrm{~A}$ and $4 \mathrm{~B}$, have a combined capacity of 427 tons ( 470 short tons). These silos are located on the 
front side of the circulating AFBC boiler. They are sized to provide eight-hour storage of $6 \mathrm{~mm} \times 0$ (1/4 $y_{0} 0$ in) coal at maximum continuous capacity while firing the higher heating value "A"-type coal. Each silo has three slot discharge openings designed to maintain mass flow movoment to each of the six boiler gravimetric feeders. Each silo discharge is equipped with a manual slide-gate valve for isolation and feeder maintenance. These silo outlet valves were included in the circulating AFBC boiler coal-feed system.

Coal dusting from the existing portion of the plant coal handling system is minimized by a dust-suppression system. The existing dust suppression system consists of a solution tank and pump located in the transfer house, solution distribution piping, and spray rozzles. Dust-suppression fluid is sprayed at coal transfer points on the following pieces of equipment:

- Trisk unloading hopper

- Primary crusher vibrating feeders

- Secondary crusher ribrating feeder

- Unloadins belt convejor $1 \mathrm{~A}$

- Unloading velt conveyor A

- Plant belt converor $\mathrm{C}$ at transfer house

- Plant belt conveyor $\mathrm{C}$ at reclaim hopper

- Stack-out belt conveyor B.

The various new components in the coal handling system are the en-masse conveyors, crushers, and silos. These components are served by a single coal dust collection system. This collection system consists of an exhaust fan capable of 400 cubic $\mathrm{m} / \mathrm{min}$ $(14,000 \mathrm{cfm})$, and a pulse-cleaned bag filter sized for an airto-cloth ratio of 5 to 1 . The collected dust is discharged into coal silo 4A throu. $h$ a rotary valve. The new dust-collection system is automatically activated upon the start of either of the new coal handling trains and remains in operation until $30 \mathrm{~min}$ utes afier the last coal handling train is stopped.

\subsection{Limestone Handling System}

The limestone-handling system provides for receiving, transferring, storing, and preparing the limestone before it is injected into the circulating $A F B C$ boiler combustors. The system includes all limestone-handling equipment from the truck receiving hopper 
to and including the bojler limestone silos. This: systom is: entirely new. A flow diagrain of the plant limestonominditing system is presented in Eigure 19.

The circulating AFBC boiler combustion process roguires limostone ground to a top size of 1000 microns and averaye sizo of 150 microns, ranging in quantity from 680 to $11,350 \mathrm{~kg} / \mathrm{hi} \quad(1,600$ to $25,000 \mathrm{~b} / \mathrm{hr}$, depending on the coal-feed rate, coal guality, and measured flue gas so, concentration. The limestone-handing system consists of receiving facilities dosigne for 68 consinr (75 short tonsinr), and pulver:zing- and pneumit ic-onvoying facilitios designed for 8.2 to.s/hr (9 short tons/hr). The limestone-roeiving facilities include equpment for unlouting, crushing, and conveyng limestone to the storage silo. From the storage silo, the limestone is reduced to its final siac by a pulverizer system and is pneumatically conveyed to ejthor of two boiler limestone silos.

Saw limestone rock is delivered from a local quarry to the receiving system by over-the-road trucks and dumped inte a receiving hoper. A vibrating footer delivers the inmestone into a primary rock erusher. The couster is a reversible hamermill

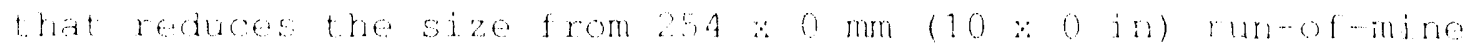

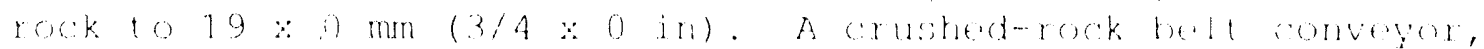
with integral belt conveyor, and haket olovator are all rated for 68 tonsth (75 short tonsine). Tho bucket elovator lifts the crushed limestone approsimatoly $30 \mathrm{~m}$ (100 ft) vertically into a $772-10 \mathrm{n}$ (850 short ton) capacity, elevated limestone storage silo. This represents approsimatoly a o-hour storago capacity at masimum boiler ut ilization.

The otorage silo feeds the limestone mulvolizot system. The linestone storage silo and palver iner system are lonatod outdoor:

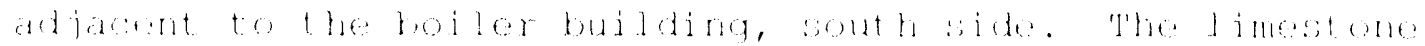

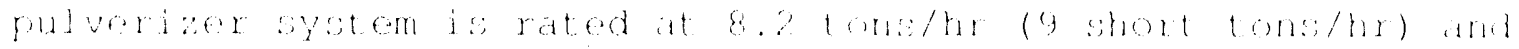

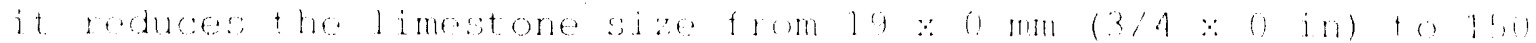

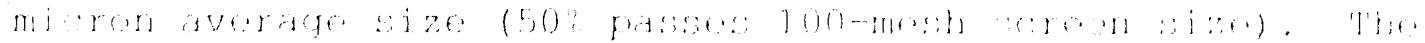

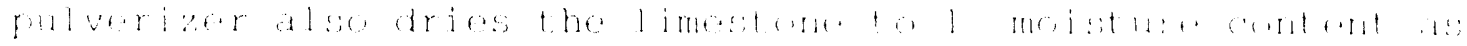

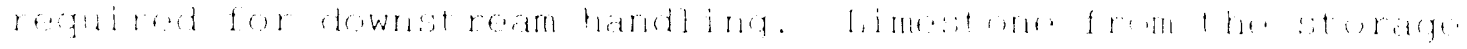

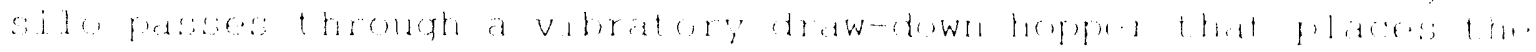

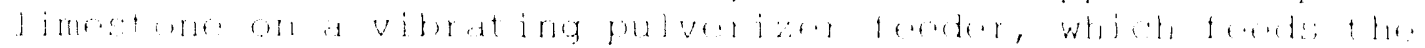

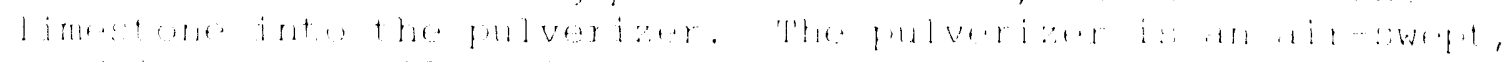

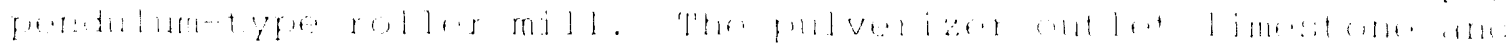

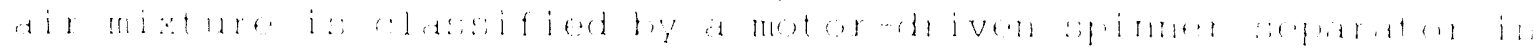

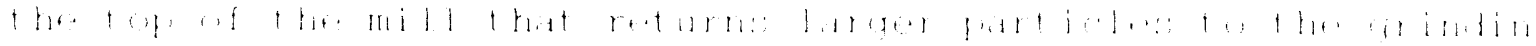

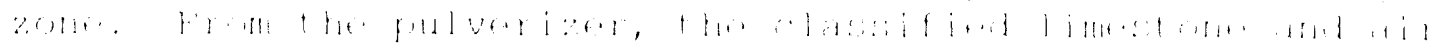

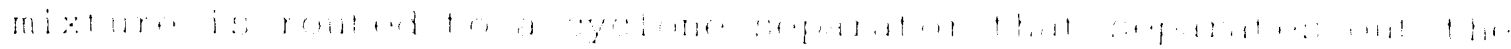

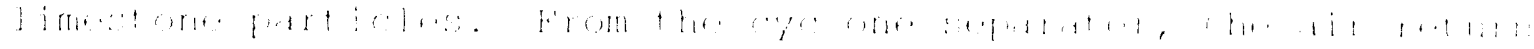

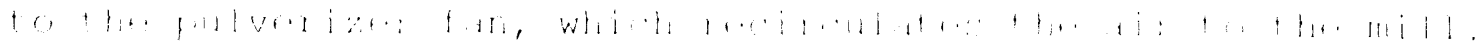

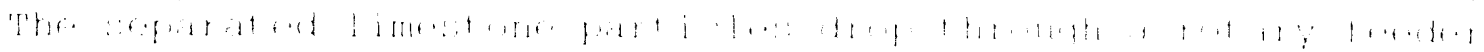




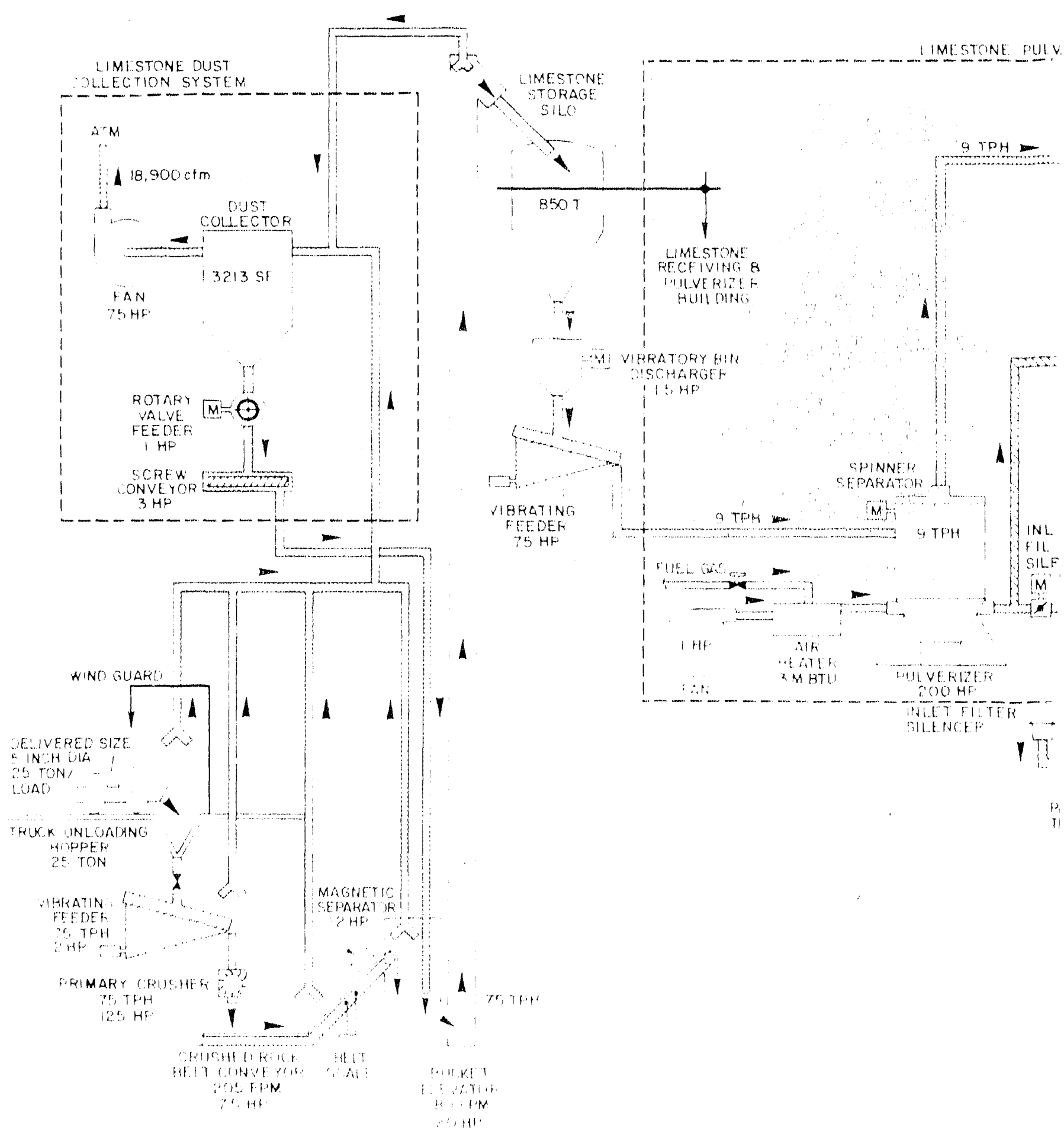




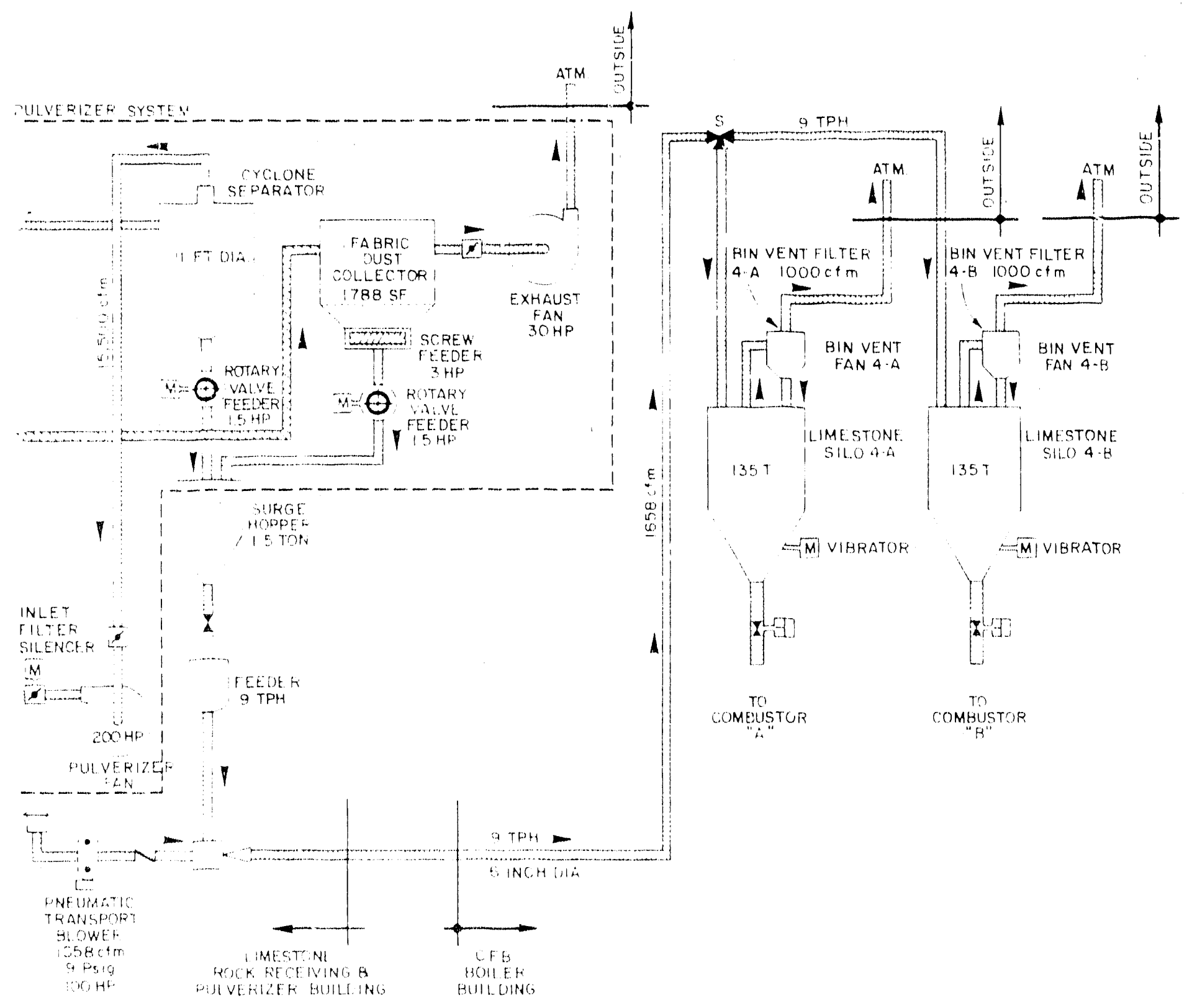

FIGURE 19

LIMESTONE HAROLING FLOW DIAGRAM 
into the pneumatic conveying system surge feed hopper. Pulveriaer makeup alr is heated by a gas-fired heater. The hoater is requitred to dry the final product to a specilied lo molsture content. Air is bled from the pulverizer-fan discharge to a fabrichilter collector and an exhaust fan. The ent iro limestone-pulverizer system is maintained at a slightly negat ive pressure by the fabrio-filter exhast fan. Tho fabric-filtor discharges collected limestone dust via a screw and a rotary feeder to the pneumatio conveying system surge feed hopper.

Pulveriad limestone collocted in the foed-surge hopper: is transported from the limestone-pulveriang area to the limestone silos (lomend in the boiler hulding) by a pressurizod pnoumat io conveying system rated at $\$ 3.2$ tons/hr (9 short tons/hï) (anderity. In adihtion to the suras foed hopper, the pneumatio convoying system consist of a rotary feoder, an acoeloration chamber (intake tee), d wat? postive displacemert conveying air how

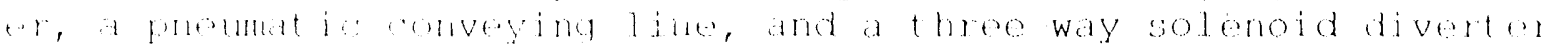
value to dirent the limestone to the selocted bot lor limestone

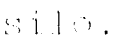

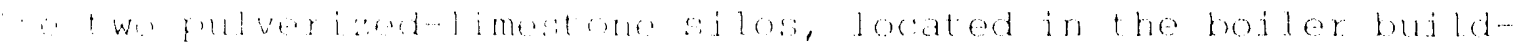

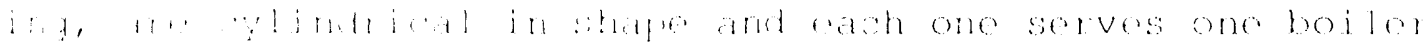

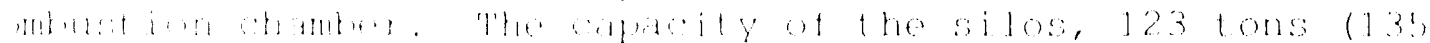

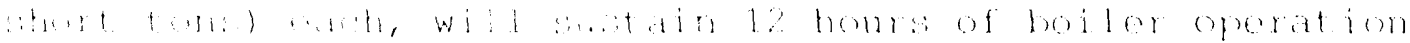

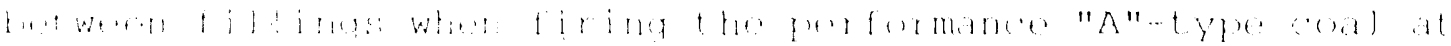
$111 ! 1,1,1$.

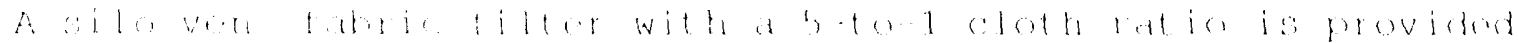

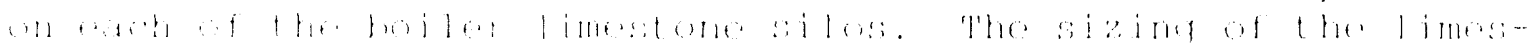

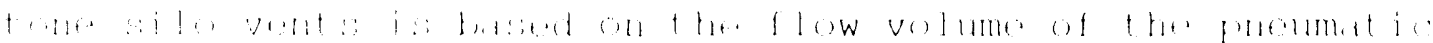

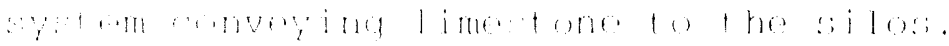

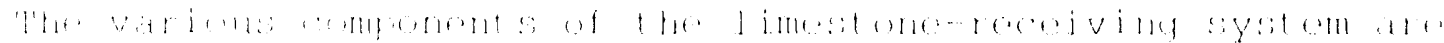

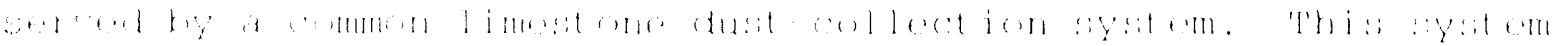

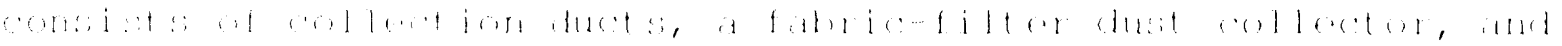

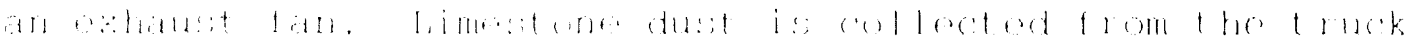

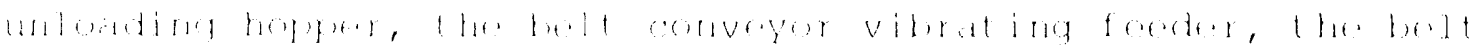

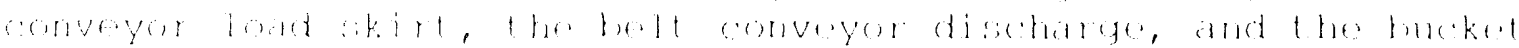

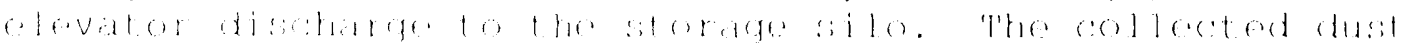

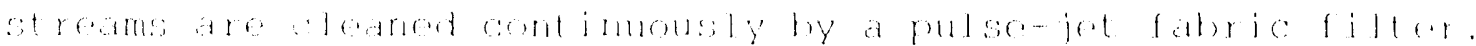

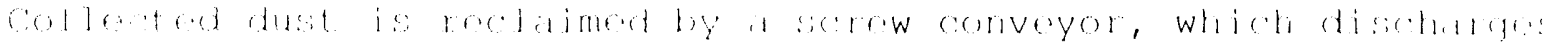

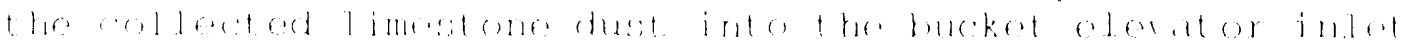
hisperin:

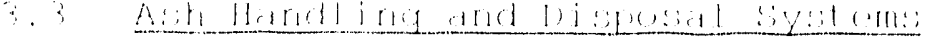

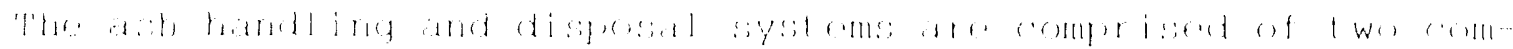

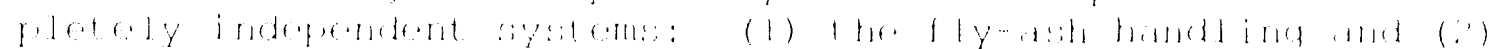


the bottom or spent-bed ash handling systems. The fly-ash handing system provides for the removal, transfer, storage, and disposal of fly ash that is collected in the boiler economizer hoppers, air heater hoppers, and the various baghouse fly-ash collection hoppers. The bot tom ash handling system provides for the removal, cooling, transfer, storge, and djsposal of spentbed ash drained from the bot om of the circulat an AFBC boiler combustion chambers. An ash-reinjection subsystem is provided, as part of the bottom ash-handing system, to facilitate return of stored spent-bed ash from the bottom ash-storage silo to etther combut ion chamber. This material is used to re-estabis ah a bed of inert material, as roquired for boiler startups.

"he bottom/fly ash distribution for the Nus cioulating ArlBC: boller was origina?ly predicted to be 20 to $40 \%$ bottom (bed drain) ash and so to 80 tly ash. This prediction was hased on

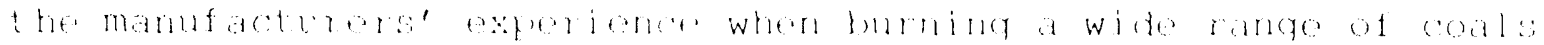
that averagen 35 bot om ash. Combust ion tost ing of the Hureta

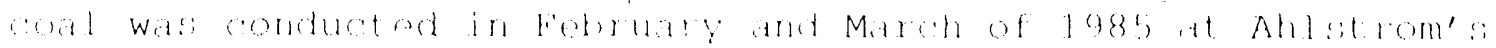

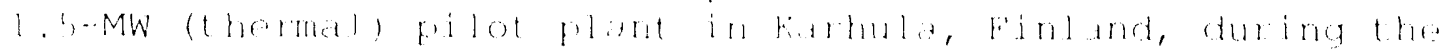
design phase of the propere. Bot tom ash distributions for theso tests was as low as 0 an! averaesed only bs of the total asn. bust ions alose as to whether the ocal ash was very friahlo

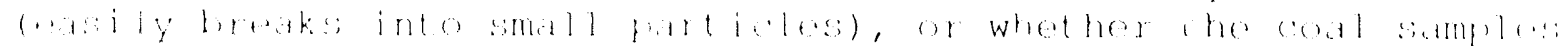

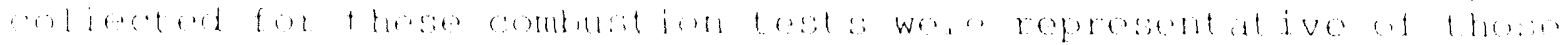

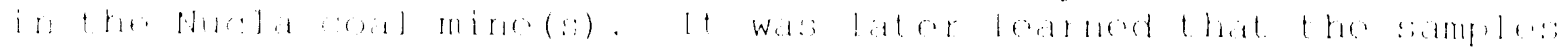

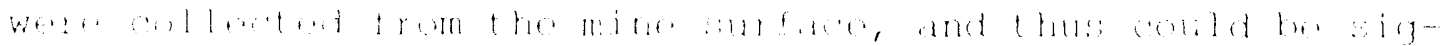

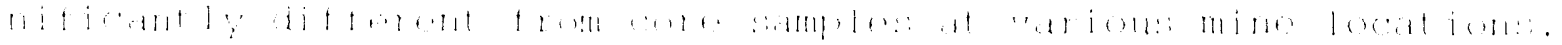

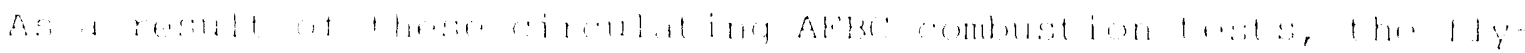

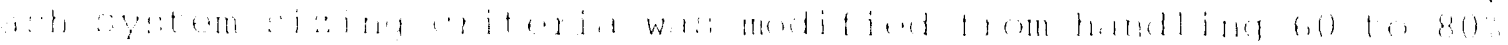

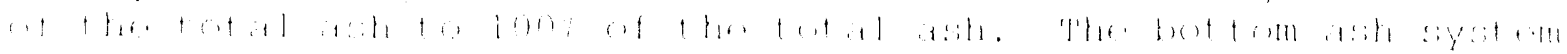

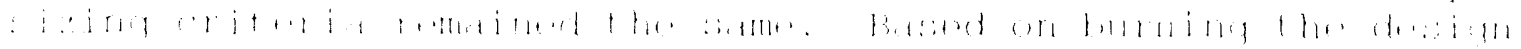

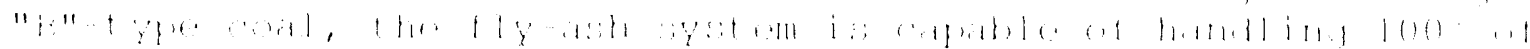

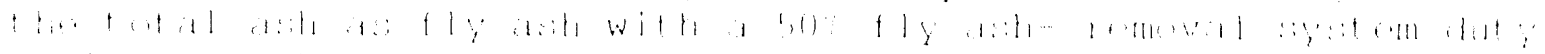

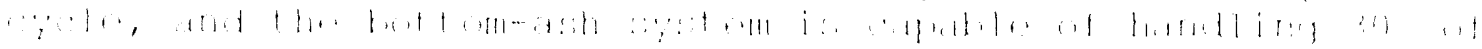

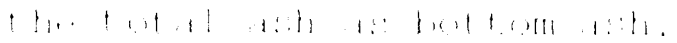

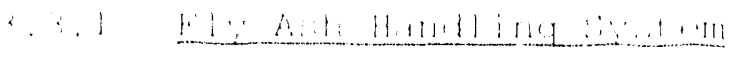

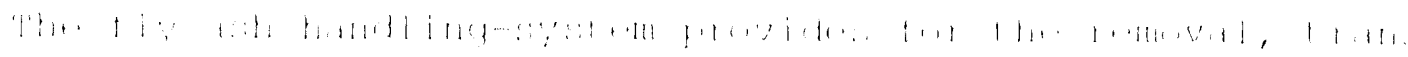

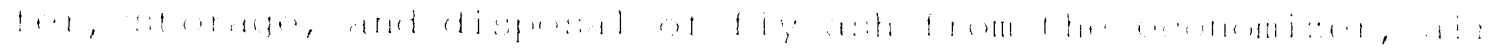

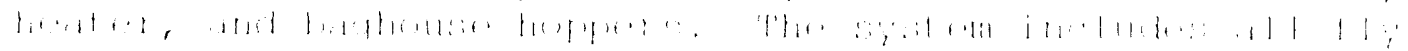

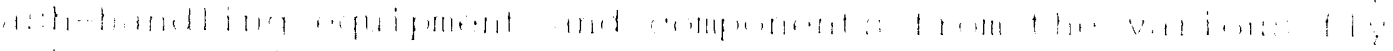

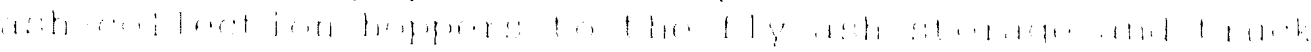

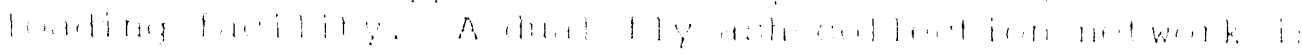

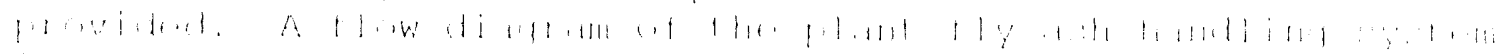

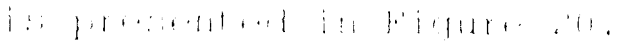




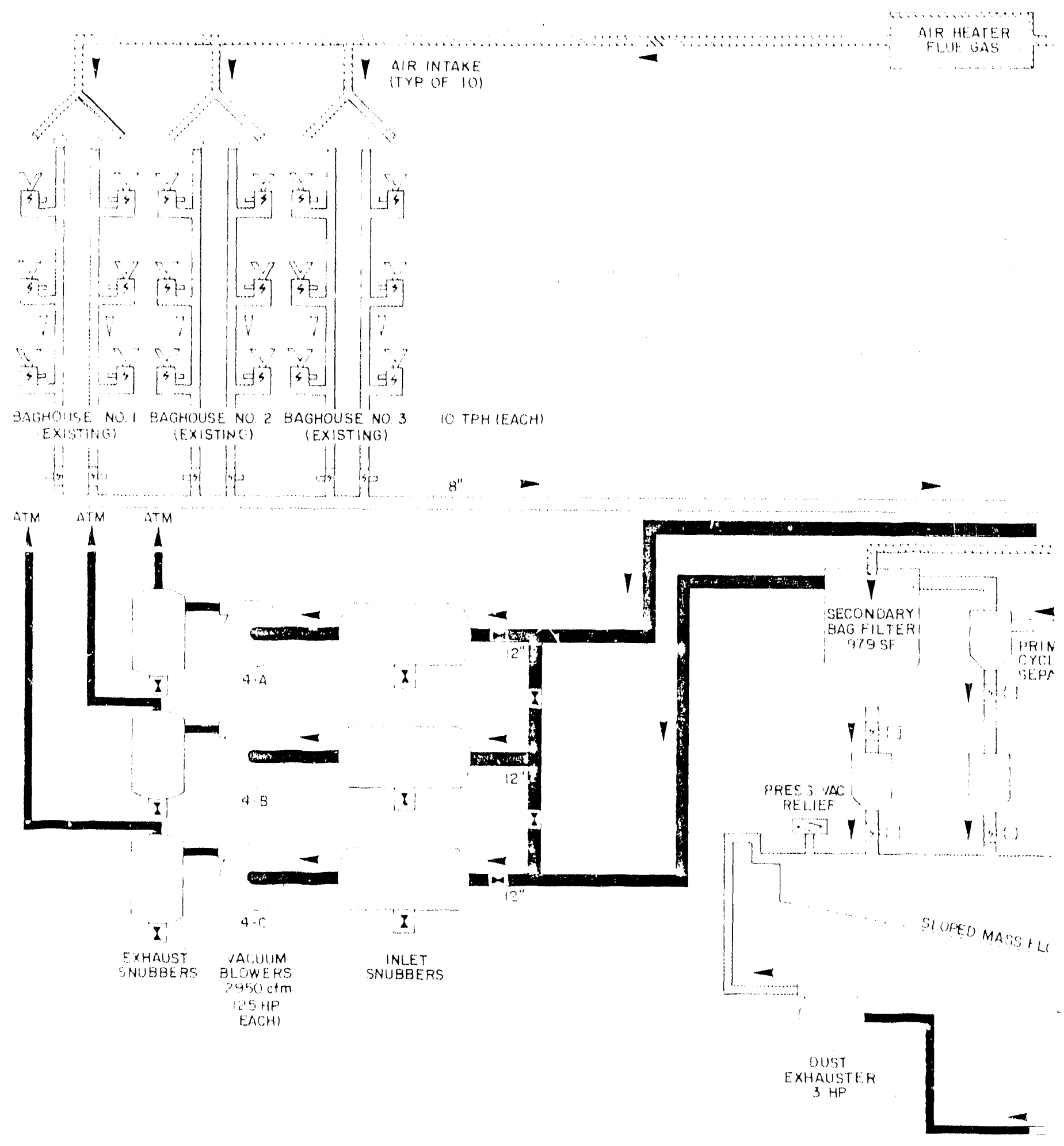



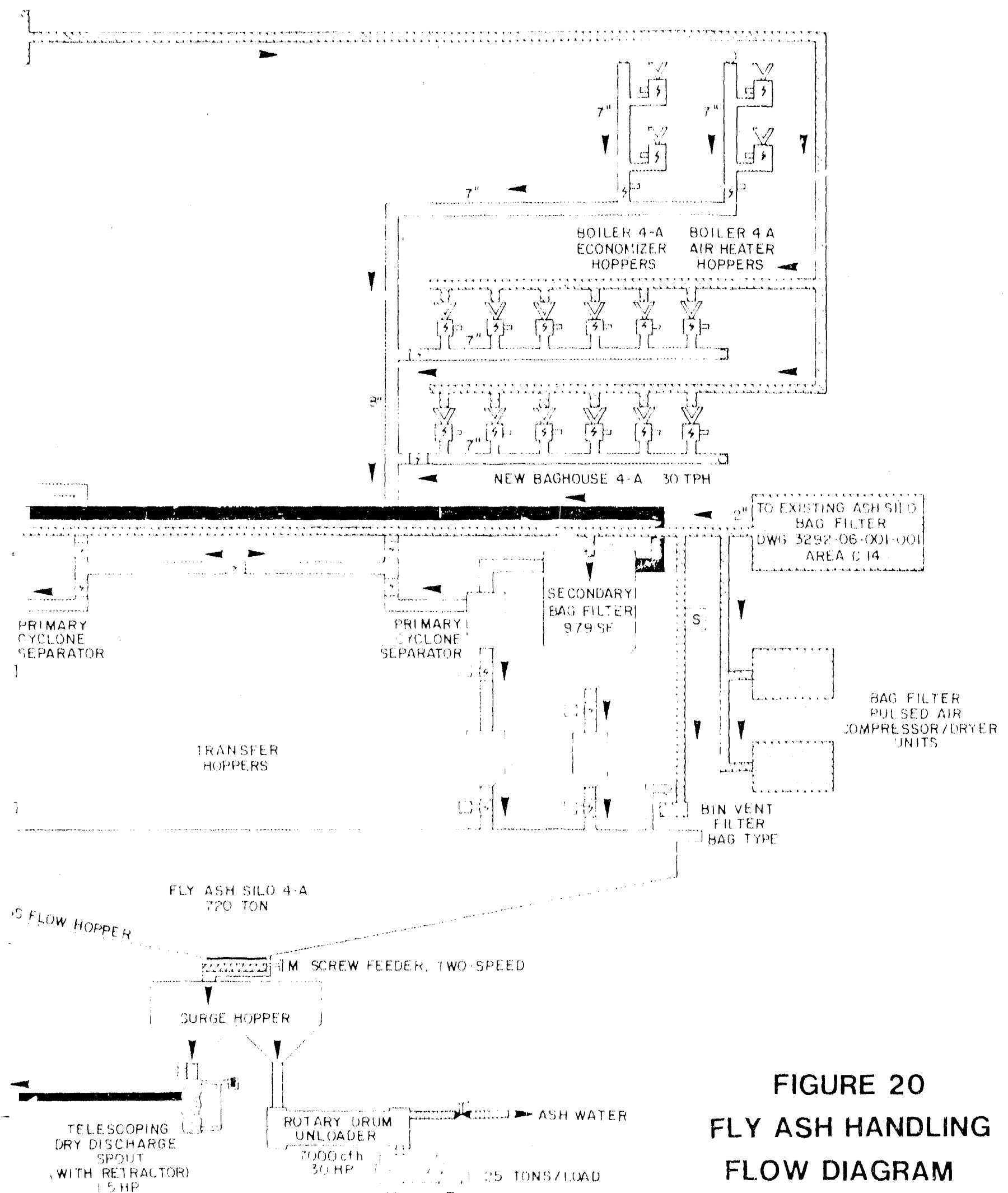

FIGURE 20

FLY ASH HANDLING FLOW DIAGRAM 
Two independent 27 tom/hr (30 short ton/hr), vacummotye pmemat is comveying systems are provided to transter fly ash trom the collut ion hoppers to a row fly-ash silo. one gystem selves the those oxisting baghoses; and the second system selves the now baghouse, tho bofiler economizer hoppor, and the air heater wht lot hoppors. The thy ash is oonvoyed lo a new 1,700 cub, om $(60,000$ cubio ft) mass flow silo.

To moot tho gesired ") ton/hr (30 short ton/hr) conveying rato ím extstin baghuses $1-3$, it. was necessary to inorease the existing branch tine pipe sizes from 15 to 18 on internal lifametor (6 in to 7 in). This was accomplished by reusing the existing ash feed gates lacated on each of the 18 fly ash hopers bix per baghose, and by replacing the out let pipe monectims. This enabled the use of ident ical mechanical oraust fans for both vacuum phoumatio systoms. Iho fly-ash anveying line length is apposimatoly $91 \mathrm{~m}(300 \mathrm{ft})$ from tho oristing baghouses.

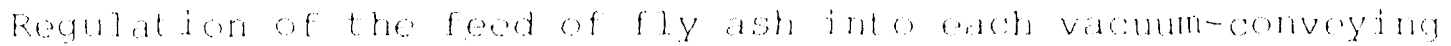

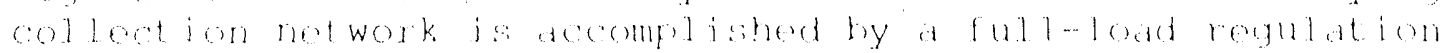
system. Whon the vacum at the vacum blower or oxhaster

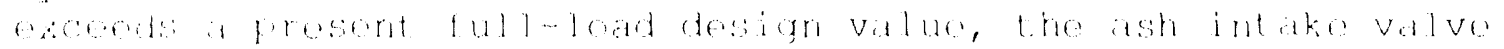

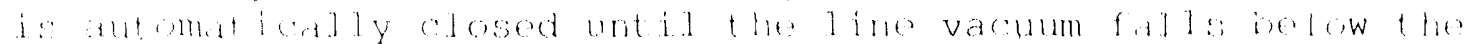

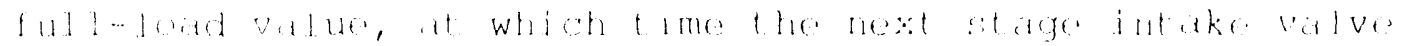

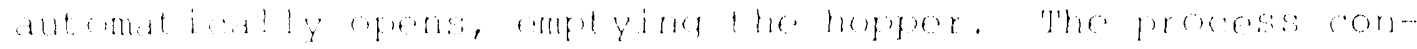

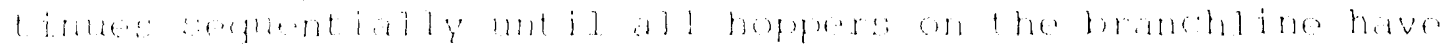

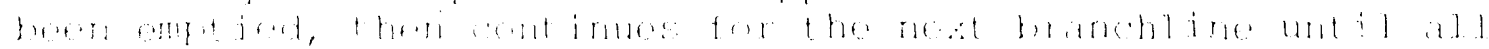

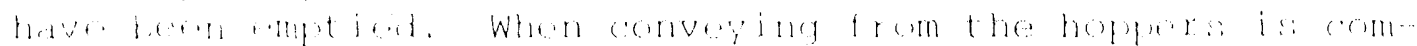

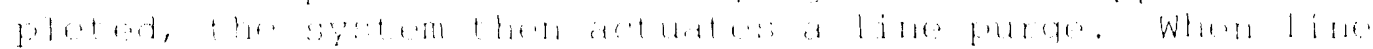

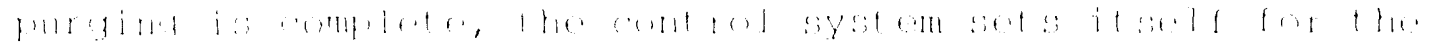

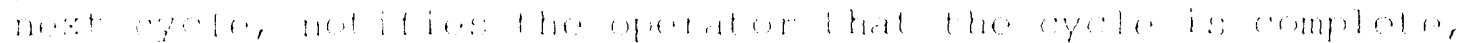

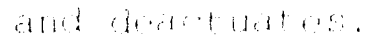

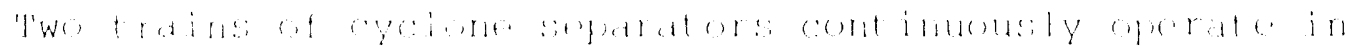

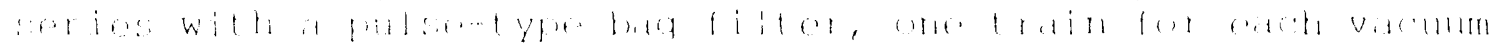

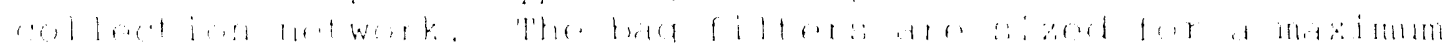

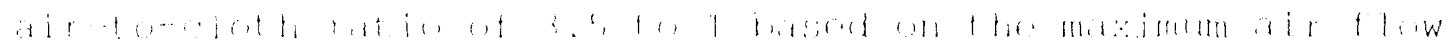

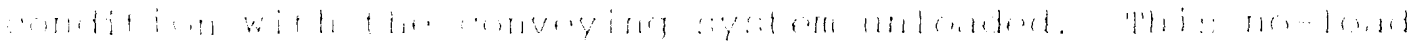

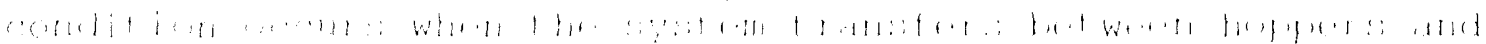

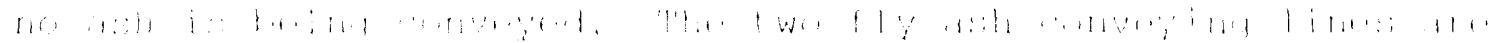

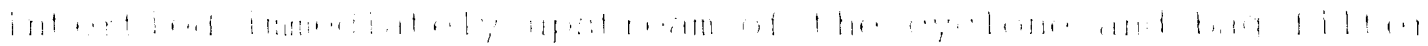

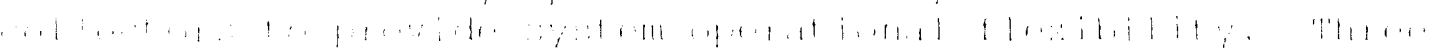

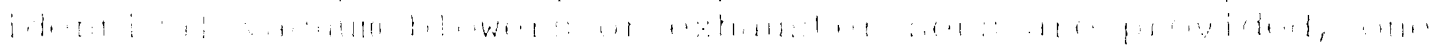

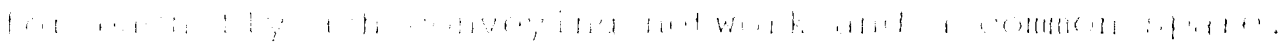

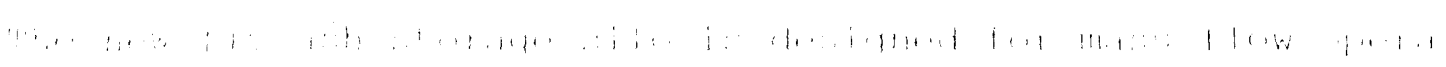

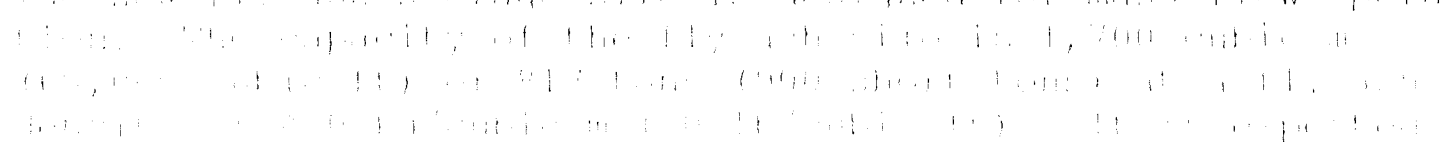




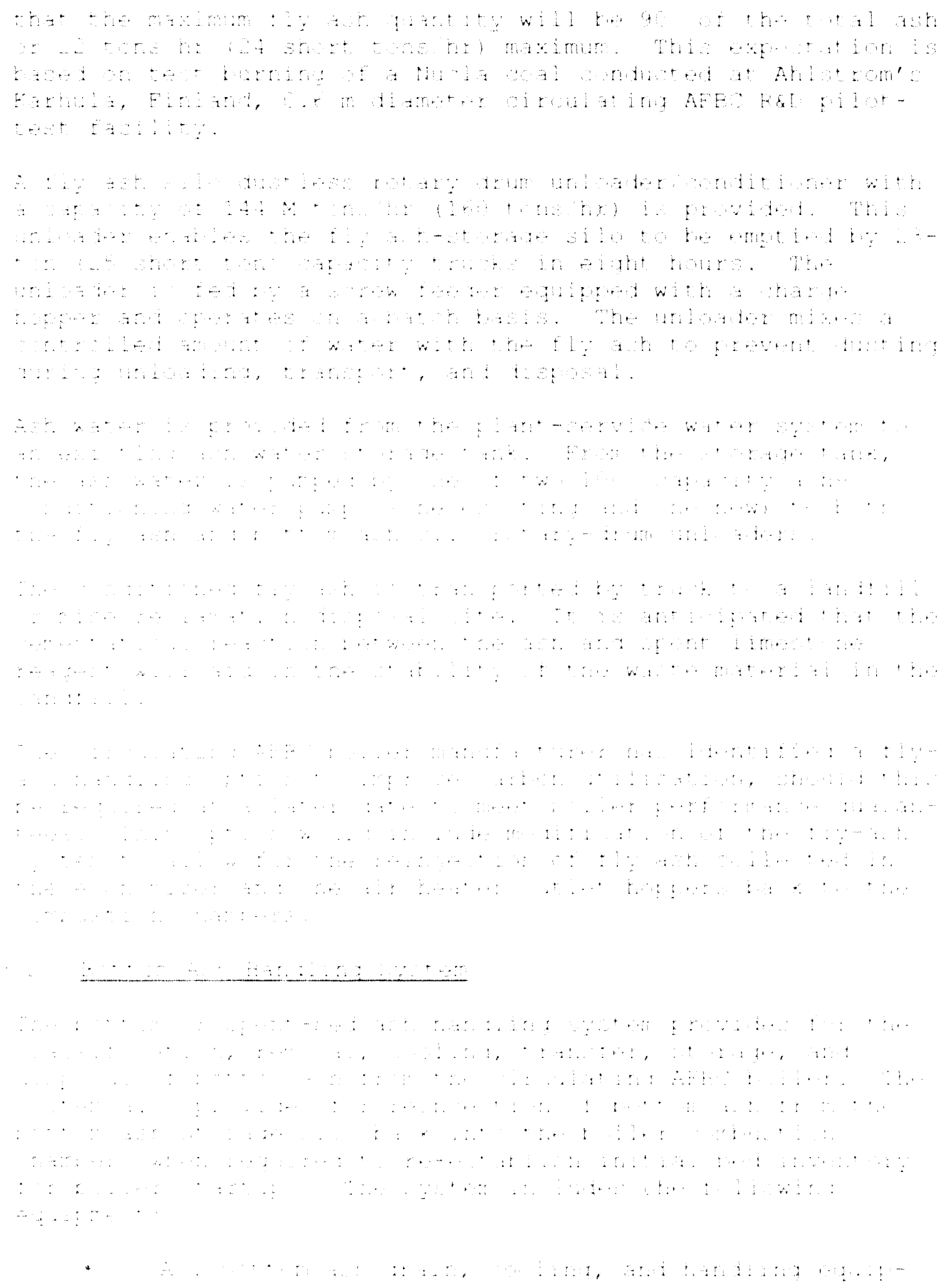


Components from the combustion chamber sidewall bot om ast ports to the ash haul truck-filling facility.

- Eottom ash rejation from the bottom ash silo to a rear-wall reinjection port located on each combust. on chamber.

A tow diagram of the plant bot tom ash-handling system is presented in Figure 21.

Woperaing upan the foud siae and friability of the fuel, the gharity of ash removed from the hot tom of the combustion nambers an war" between $10 \%$, for "A"-type cod, to more thin A. E the total ash. The vucla coal ash teris to ki th into Ene patioles easiz (high friability inder), thereiore, it

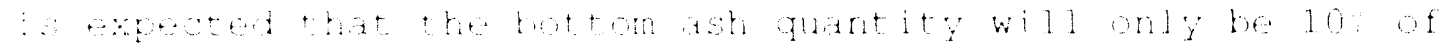

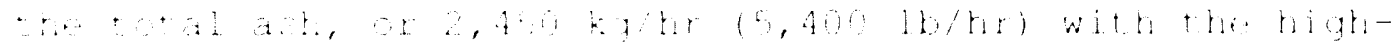

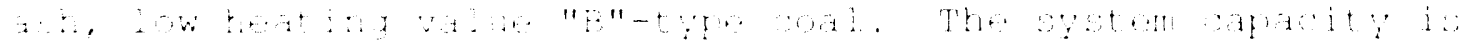

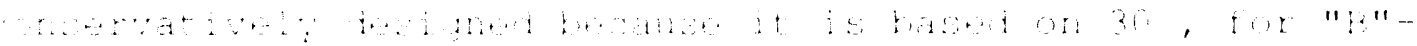

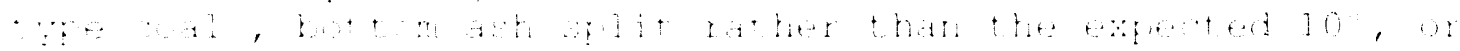

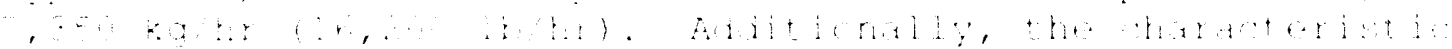

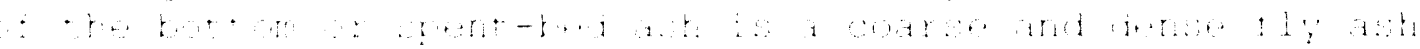
$\because+\cdots+\cdots+1, \cdots+\cdots$

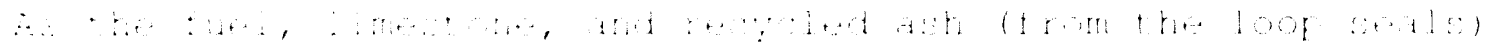

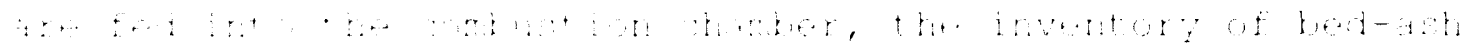

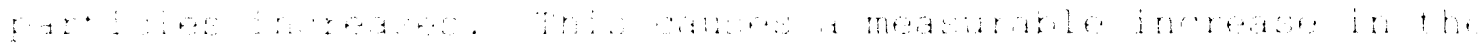

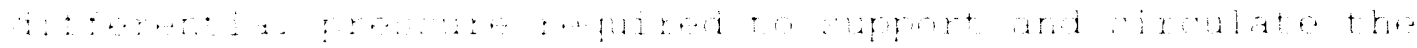

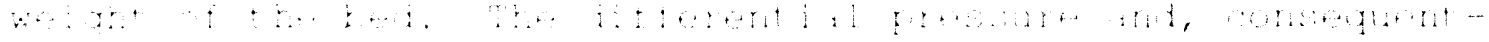

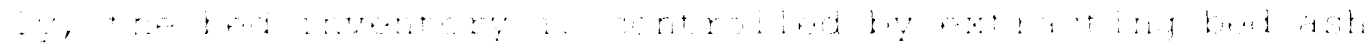

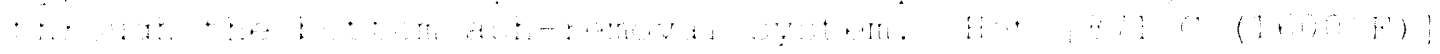

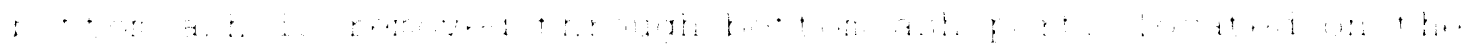

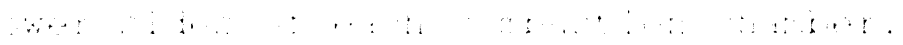

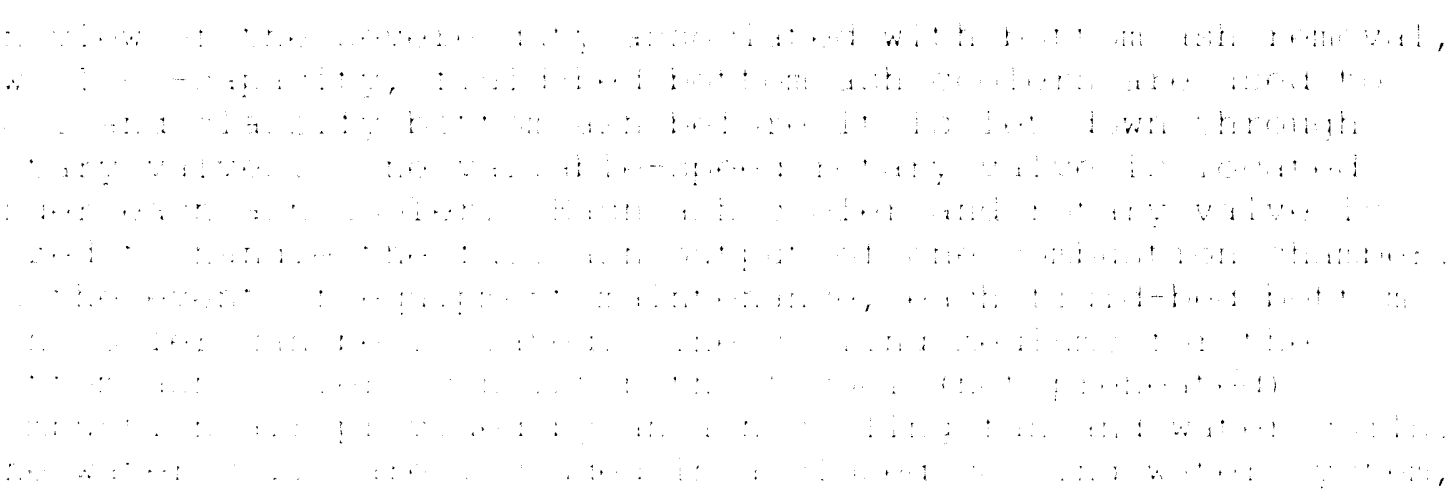




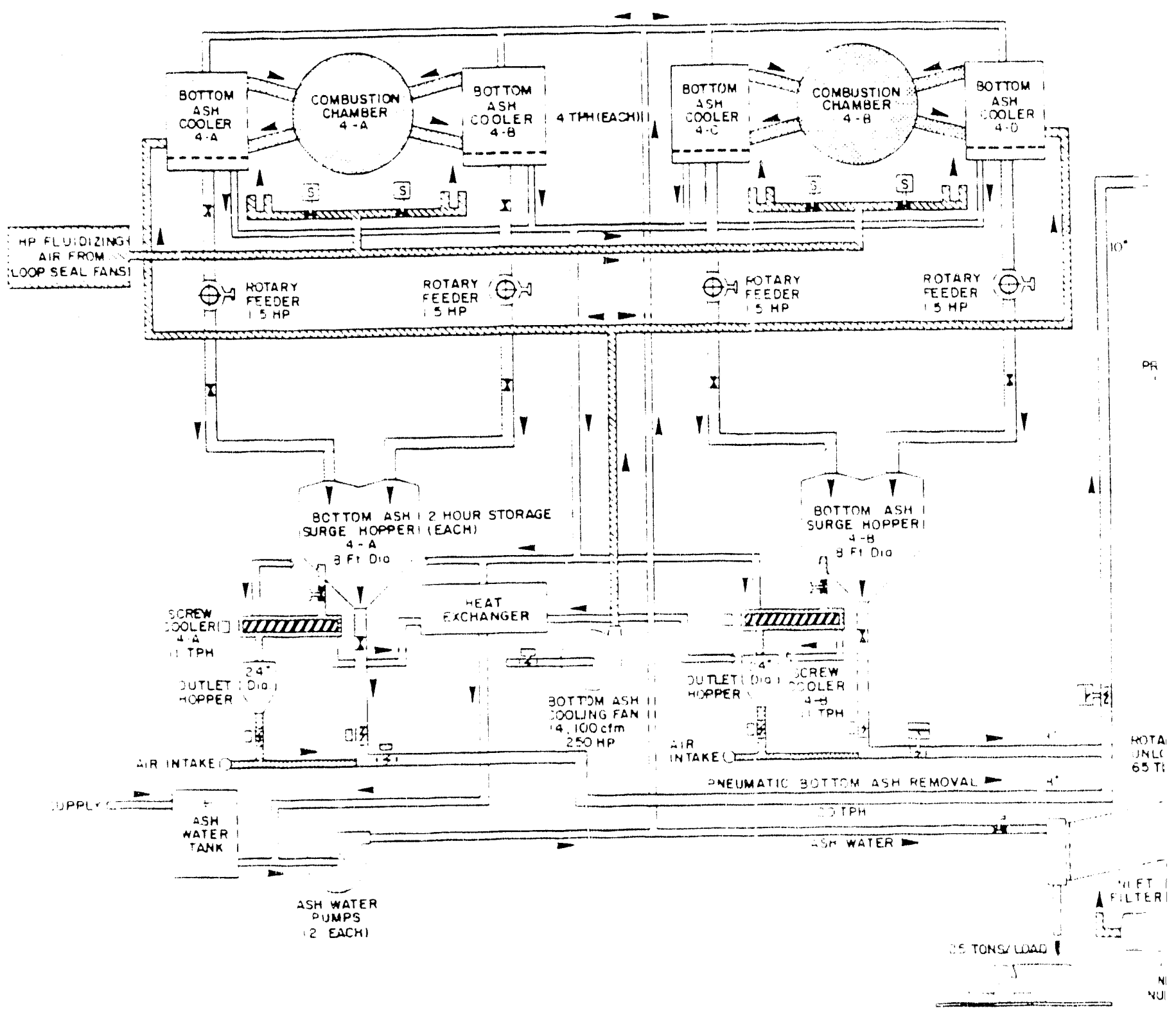



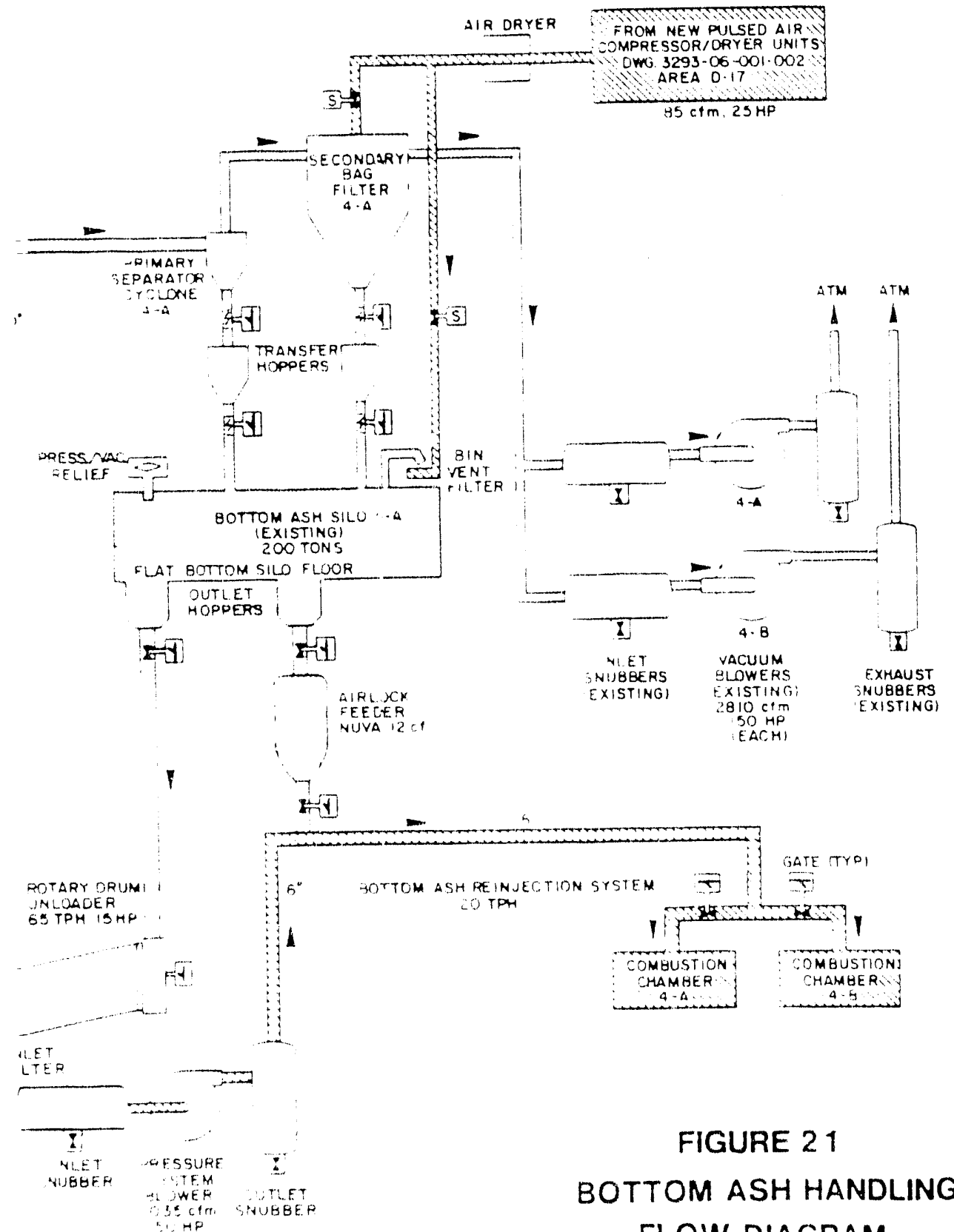

FIGURE 21

BOTTOM ASH HANDLING

FLOW DIAGRAM 
whith rocovers and thassfors heat trom the bot tom ash to the

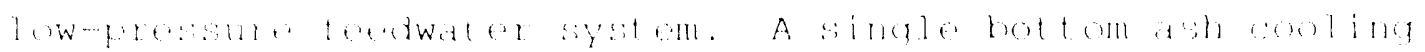

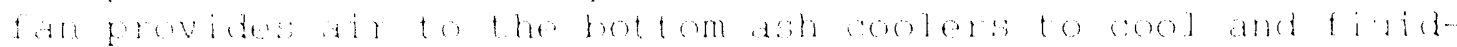
$: \because+1,0$ ash

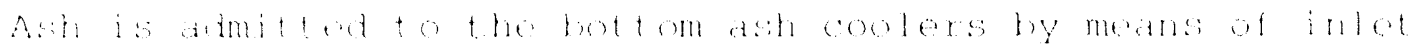

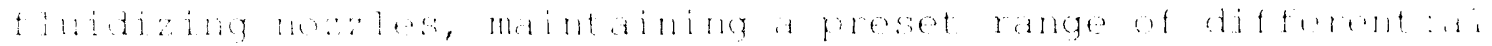

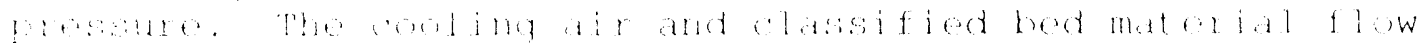

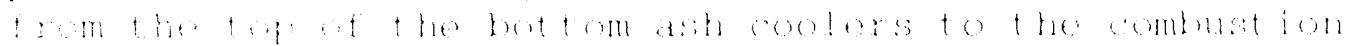

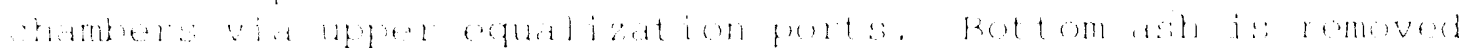

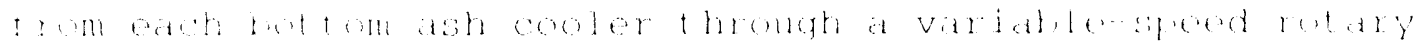
Ut ve, whi h is regulated by the operator to conter the

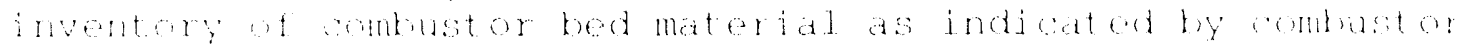

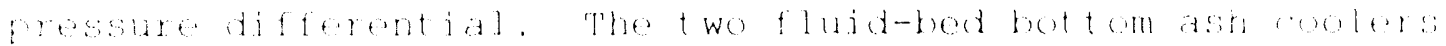
serving eath combut ion chamber discharge into a singla hot tom

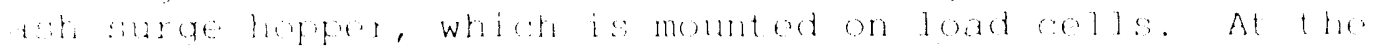

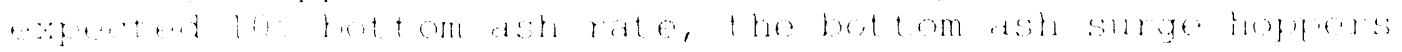

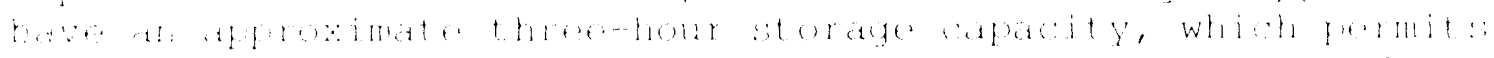

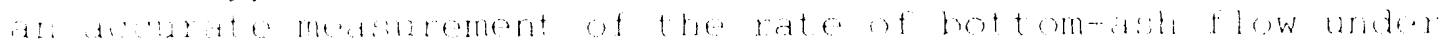

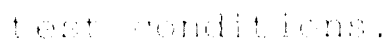

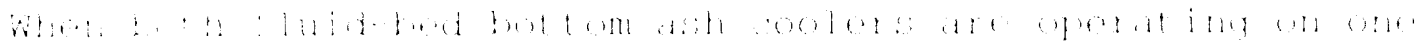

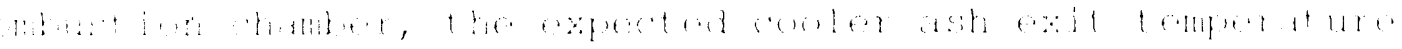

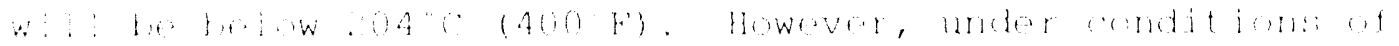

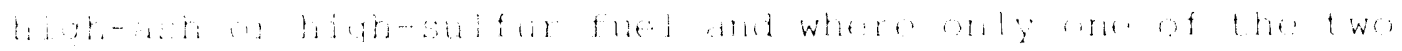

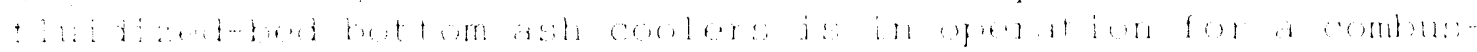

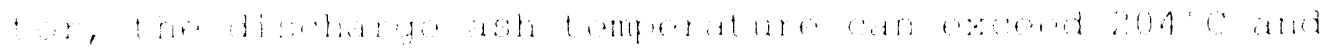

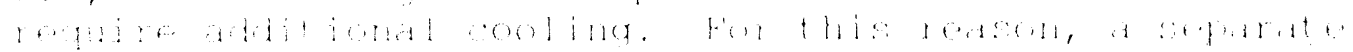

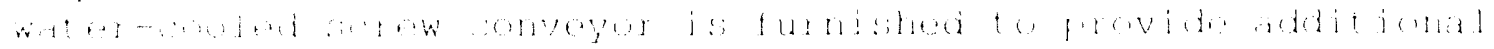

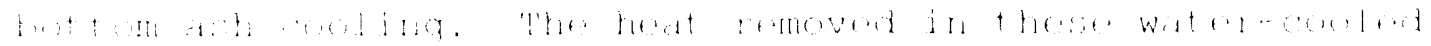

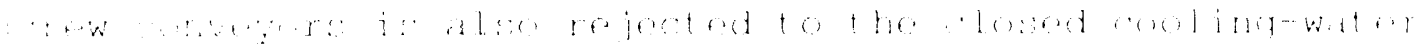

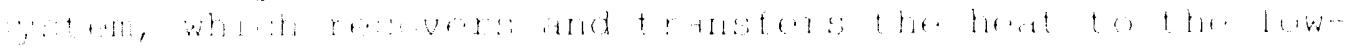

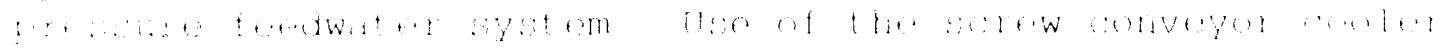

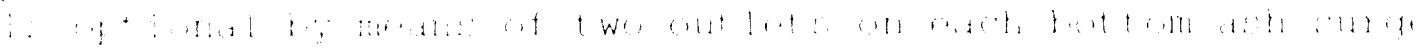

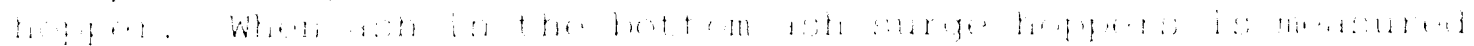

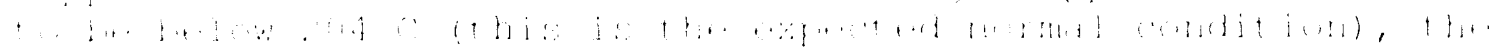

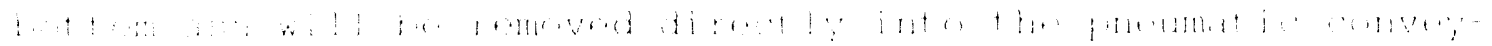

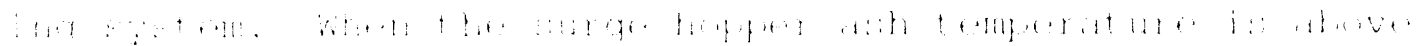

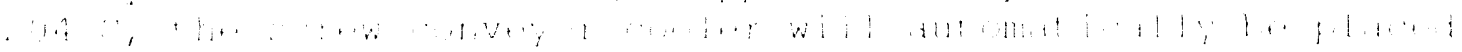

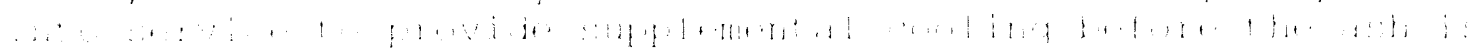

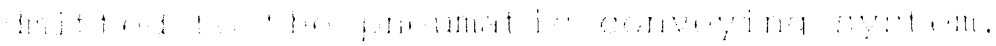

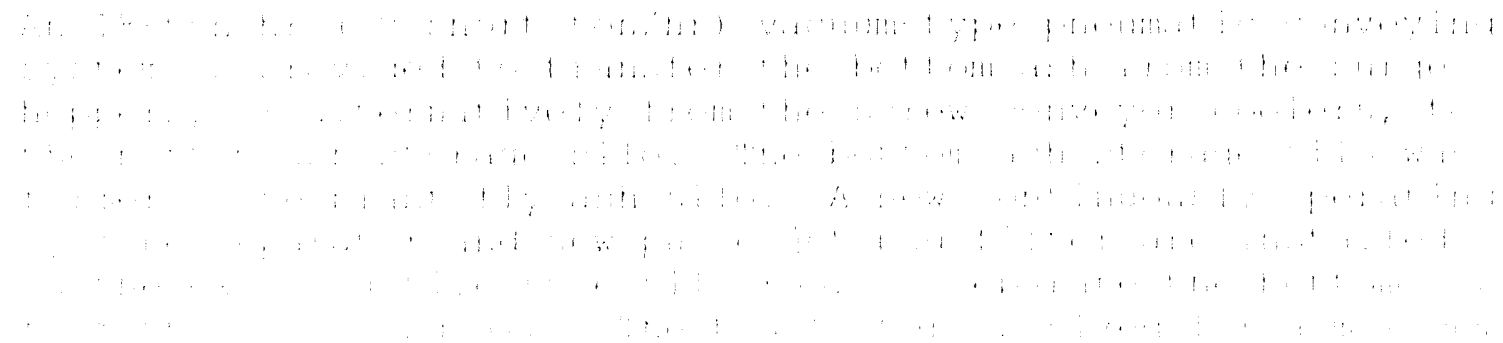


air-to-cloth ratio of 3.5 to 1 at the no-load condition, which occurs when the system transfers between hoppers and no ash is being conveyed. Two existing vacuum blowers or exhauster sets, one operating and one spare, have been reconditioned and upgraded to provide the conveying motive forct. The former plant fly ash system was also rated at 18 tons/hr (20 short tons/hr).

The existing flat bottom-ash silo, now used exclusively for bottom ash storage, has a capacity of 252 cubic $m(8,890$ cubic ft) and 181 tons (200 short tons) for a fly ash density of 720 $\mathrm{kg} / \mathrm{cubic} \mathrm{m}(45 \mathrm{lb} / \mathrm{cf})$. However, the density of bottom ash is expected to be $1,200 \mathrm{~kg} / \mathrm{cubic} \mathrm{m}(75 \mathrm{lb} / \mathrm{cf})$. Thus, the useful volume of the silo is limited to $60 \%$ or 151 cubic $m(5,333$ cubic ft), not to exceed the 182-ton (200 short ton) capacity. Bottom ash-storage silo discharge equipment includes three silo outlet hoppers (one each for the existing unloader, a dry unloading spout, and a new reinjection system pressure feeder). The unloader mixes a controlled amount of water with the bottom ash to condition it for over-the-road truck transport and final disposal i.r a landfill or mine reclamation disposal sile.

A pressurized ash-reinjection subsystem is provided as part of the bottom ash-handling system to re-establish the fluidized bed following boiler outages. The bottom ash-reinjection system includes one airlock Nuva gravity feeder to transfer the ash from the storage silo into a pressurized pneumatic conveying line. This pneumatic system conveys the bottom ash back to the bottcrn of each combustjon chamber through a single ash reinjection port located in the lower rear wall of each combustor. A single blower provides the pressurized conveying medium: air. 
Section IV. Balance-of-Plant Mechanical Equipment and Systems

The balance-of-plant mechanical equipment and systems include the power and process piping, plant water systems, circulating water system, the condenser and accessories, chemical-feed systems and miscellaneous mechanical equipment. These are used to help convert mechanical energy to electrical and support that end. Description of the facilities and systems is included in this section, while data is provided in Appendices $A$ and $B$.

\subsection{Power and Process Piping}

The power and process piping provides for the transfer of turbine cycle steam, condensate, and feedwater for each of the three existing units (1-3), for the new Unit 4 and integral inter-unit transfers. The power and process piping is comprised of the following systems:

- Main steam

- $\quad$ Extraction steam

- Auxiliary steam

- Low Pressure (LP) feedwater

- High Pressure (HP) feedwater.

\subsubsection{Main Stoam System}

The main steam system delivers superheated steam from the unit 4 AFBC boiler supe heater III outlet connection to the Unit 4 turbine. The system consists of the new main steam line and hangers from the boiler final superheater outlet connection to the two unit 4 turbine stop valves. Also included is main steam line instrumentation, a sample conrection, a turbine gland steam connection, and an electromatic relief valve. The entire system is part of the new Unit 4 installation. The existing Unit 1-3 main steam lines have been disconnected from the boilers and have been partially dismantled.

Main steam temperature is controlled to $541^{\circ} \mathrm{C}\left(1005^{\circ} \mathrm{F}\right)$ at the boiler superheater III outlet by two stages of attemperation; one between superheaters I and II plus one between superheaters II and III.

Drains are provided at all. Low points, and a vent is provided at the high point of the main steam line. The drains are routed. O the boiler blowdown tank and to the condenser via the turbine HP drain header. The vents and drains allow for 
warming of the main steam line prior to starting the turbine and provide a means for condensate removal to protect against turbine water induction. The main steam line drain and vent valves are all manually operated.

\subsubsection{Extraction Steam System}

The extraction steam system provides for the supply of throttle steam to the existing Unit 1-3 turbines from the Unit 4 turbine, and extraction steam to the feedwater heaters. The extraction steam system includes:

- The new Unit 4 turbine controlled automatic extraction nozzle to the inlet connections of the existing Unit $1-3$ turbines.

- The Unit 4 turbine uncontrolled extraction connections to the inlet steam connections of the Unit 4 HP and LP feedwater heaters, including the deaerator.

- The uncontrolled extraction connections on the existing Unit 1-3 turbines to the Unit 1-3 LP feedwater heaters including the deaerators.

- The feedwater heater shell side vents and drains on all units.

The Unit 4 deaerator extraction also serves as a plant auxiliary steam source.

\subsubsection{Units $1-3$ Extraction Steam}

Units 1-3 each have identical extraction steam systems.

The Unit 4 turbine automatically controlled extraction is the source of the throttling steam for each of the existing turbines. This steam source is also used on each existing unit to supply the condenser steam jet air ejector, the hogging jet air ejector, the turbine steam seal regulator, and the steam turbine driven auxiliary lube oil pump. During startups and shutdowns, auto extraction header steam is supplied from the circulating $A F B C$ boiler primary superheater outlet header auxiliary steam supply source. Auxiliary steam is also required at these times for operation of the above-listed Unit 1-3 condenser and turbine accessory equipment items. The auto-extraction header supplying the existing turbines is protected from overpressure by a safety valve set at 49 $\mathrm{kg} / \mathrm{cm}^{2}$ (700 psig). 
The highest pressure extraction from each Unit 1-3 turbine formerly supplied steam to a HP feedwater heater on each unit that has been retired as part of the existing plant modification to incorporate the new Unit 4. For each unit, this extraction has been capped off immediately downstream of the extraction line turbine isolation shutoff and non-return check valve.

Each Unit 1-3 turbine has three remaining extraction steam lines supplying steam to a deaerator, and two LP feedwater heater stages. Each extraction steam line is provided with a manually operated shutoff valve and a non-return check valve. The non-return check valve protects the turbine against reverse flow in the extraction line, which could cause turbine overspeed and/or water induction. Each deaerator extraction line has two non-return check valves in series to provide additional turbine overspeed protection due to the large potential of flash steam in the deaerator storage tank. The extraction line low points between the turbine and the extraction line shutoff valve are drained to the condenser via steam traps.

The existing LP extraction feedwater heaters are not provided with operating vents for the continuous removal of non-condensable gases to the condenser. A.tmospheric startup vents must be opened periodically to vent noncondensable gases that may be present in the heater. shells. The existing deaerators are provided with both a startup and an orificed operating vent to atmosphere that remove air and other condensable gases.

On each existing unit, the higher-pressure LP feedwater heater shell drains cascade to the lower pressure LP feedwater heater shell. The lower-pressure feedwater heater shell drains to the condenser. Both LP feedwater heater shells are provided with an alternative manual drain to the condenser.

\subsubsection{Unit 4 Extraction Steam}

All Unit 4 turbine extraction steam lines contain a motoroperated shutoff valve and a power-assisted check valve. The motor-operated gate valve is provided for positive isolation of the turbine from any potential sources of water induction. The second valve, a power-assisted check valve, is provided to protect the turbine against reverse flow in the extraction lines, which could cause turbine overspeed and/or water induction. Due to the large potential for flash steam in the deaerator storage tank, 
the deaerator extraction line has two power-assisted check valves in series, as recommended by the turbine manufacturer.

The extraction line low points before, after, and between the shutoff and check valves are drained to the condenser via manually-operated dri.in valves. Continuous flow drain lines, which include flow restriction orifices, bypass the drain valves.

The feedwater heater vents and drains consist of two subsystems for removal of fluids and vapors from the shell sides of the heaters. The vents remove noncondensable materials, such as air, and the drains remove the condensed extraction steam.

The feedwater heaters have two types of vents: startup and operating. Startup vents are larger-capacity lines for fast removal of non-condensable gases accumulated in idle equipment and piping. Operating vents are lower capacity, orificed lines that are provided for continuous removal of the non-condensable gases that may be present in the extraction steam during plant operation. Vents from the HP feedwater heaters are routed to the deaerator for removal of noncondensable gases by the deaerator vent system, which is vented to the atmosphere. Vents from the LP feedwater heaters are routed to the condenser and vented by the condenser air removal system. All startup and operating vents have manual shutoff valves.

Drains for the HP feedwater heater shells cascade to the next lower-pressure heater, and finally to the deaerator. Drains from the HP heaters flow by shell pressure differential to the deaerator. IP feedwater heater drains cascade to the next lower pressure heater and then to the condenser.

Emergency shell drains to the condenser are provided for all feedwater heaters, including the deaerator. The emergency drains automatically open on high water level in the heater shell. The emergency drains provide a first line of defense against turbine water induction.

\subsubsection{Auxiliary Steam System}

The new auxiliary steam system supplies steam for the following Unit 4 systems:

$$
\text { Deaerator steam pegging }
$$


- Condenser steam jet air ejector and priming ejector

- Condenser and deaerator storage tank warm-up spargers

- Heating system and heating deaerator.

Auxiliary steam is also supplied to the existing Unit $1-3$ heating system, the prebolier water treatment system caustic regeneration heater, and to the auto extraction line for turbines 1-3. Unit 4 auxiliary steam supplies include boiler primary superheater outlet steam, turbine deaerator steam, and an auxiliary boiler. The Unit 4 auxiliary boiler is included in the system.

Auxiliary steam supply for startup pegging of the Unit 4 deaerator and the condenser steam jet air ejector is provided from a connection on the circulating AFBC boiler primary superheater (SH I) outlet header. This auxiliary steam connection is sized to supply $12,260 \mathrm{~kg} / \mathrm{hr}(27,000 \mathrm{lb} / \mathrm{hr})$. A pressure control station reduces the pressure of this steam to $21 \mathrm{~kg} / \mathrm{cm}^{2}(300 \mathrm{psig})$. Downstream of the pressure control station there is a safety valve set at $23 \mathrm{~kg} / \mathrm{cm}^{2}(330 \mathrm{psig})$, instrumentation, drains, and a future supply connection for steam coil combustion air preheaters.

Boiler primary superheater outlet steam is also the source of backup auxiliary steam to the automatic extraction header supplying steam to the existing turbines 1-3. A pressure reducing station is provided for this auxiliary steam supply that reduces the pressure to approximately $35 \mathrm{~kg} / \mathrm{cm}^{2}$ (500 psig) entering the autoextraction line. This pressure is set to a lesser value than the automatic extraction line normal operating pressure of $44 \mathrm{~kg} / \mathrm{cm}^{2}(628 \mathrm{psig})$. This backup steam is supplied for the following equipment: hogging and steam jet air ejectors, the steam seal regulator, and the auxiliary turbine lube oil pump turbine driver on each of the existing turbine units during startups and shutdowns.

Auxiliary steam supply for the Unit 4 heating system, heating system deaerator, caustic regeneration heater, Unit 4 condenser, deaerator storage tank spargers, and the existing building heating system is normally supplied from the Unit 4 turbine LP deaerator heater extraction. When Unit 4 is out of service, this auxiliary steam is supplied from the auxiliary boiler. The Unit 4 heating system auxiliary steam supply pressure is controlled to $2.1 \mathrm{~kg} / \mathrm{cm}^{2}(30 \mathrm{psig})$ by a pressureregulating station. This $2.1 \mathrm{~kg} / \mathrm{cm}^{2}$ ( $30 \mathrm{psig}$ ) heating steam supply line is protected from overpressure by a safety valve set at $3.5 \mathrm{~kg} / \mathrm{cm}^{2}$ (50 psig). 
The Unit 4 auxiliary boiler is a new equipment item. However, the auxiliary boiler is rated at $35 \times 10^{6} \mathrm{~J} / \mathrm{hr}$ ( 600 boller HP) or $9,120 \mathrm{~kg}(20,085 \mathrm{lb})$ of $9.5 \mathrm{~kg} / \mathrm{cm}^{2}$ (135 psig) saturated steam per hour. The auxiliary boller is a gas-fired firetubetype boiler and is provided complete with a fan, instrumentation, controls, and safety valves. Auxiliary boller feedwater supply is provided from the Unit 4 heating system condensate pumps.

\subsubsection{Low Pressure Feedwater System}

The LP feedwater system includes the primary process cycle for all four units from the condensers to, and including, the unit 4 deaerator, deaerator storage tank, and miscellaneous condensate returns to the condensers. The system is comprised of the existing, modified, and new equipment on Units 1-3; an inter-unit LP feedwater transfer line to Unit 4; and new equipment for Unit 4 .

For Unit 4, condensate from the condenser hotwell is transferred by two half-capacity, vertical-centrifugal, motordriven condensate pumps. This condensate passes through the gland steam condenser, the steam jet air ejector, the ash equipment cooling water heat exchanger, and two stages of LP extraction feedwater heaters ( $4 \mathrm{~A}$ and $4 \mathrm{~B}$ ), eventually reaching the deaerating feedwater heater (4C). Individual maintenance bypasses are provided around the gland steam condenser, ash equipment cooling water heat exchanger, and the two closed LP extraction feedwater heaters. The Unit 4 deaerator is an open heat exchanger that both heats and removes dissolved oxygen from the LP feedwater. Deaerator effluent flows, by gravity, into the deaerator storage tank, which serves as a suction surge vessel for the Unit 4 boiler feedwater pumps. LP feedwater from existing Units $1-3$ is also pumped into the Unit 4 deaerator.

Units 1-3 each have identical LP feedwater systems. For each of these existing units, condensate from the condenser hotwell is pumped by two half-capacity condensate pumps through the steam jet air ejector and two stages of LP feedwater heaters ( $A$ and $B$ ) to a deaerator feedwater heater. On each of the existing units, the deaerator effluent flows, by gravity, into a deaerator storage tank; from here, it is pumped by a new full-capacity unit condensate transfer pump into a common line that delivers the LP feedwater flow from Units 1-3 to the Unit 4 deaerator. The new Units $1-3$ condensate unit transfer pumps essentially replace the original boiler feedwater pumps for their respective units. 
Each of the existing units had threp hif-capacity boiler feedwater pumps. Consideration was yiven to converting two of three boller feedwater pumps on each of the existing units to the new condinsate transfer duty. This would have required removing six of eight stages from the pumps to match the lower transfer head requirement. Uncertainties associated with this modification included hydraulic and dynamic balancing of the rotors. General pump refurbishment, new lower HP drive motors, and modification of the pump minimum-flow circuits would also have been required to convert these pumps. Tr.e decision to install new unit condensate transfer pumps on Units 1-3 was based on total evaluated costs and the technical uncertainties of modifying the old boller feedwater pumps. It was more cost effective and less risky to purchase and install new unit condensate transfer pumps than to modify the old boiler feedwater pumps.

The LP feedwater system controls on the existing Units 1-3 have been modified to be "backward looking." The former dezerator level control valves in the LP feedwater lines to the deaerators have been modified to hold the condenser hotwell level constant. The unit condensate transfer pumps' discharge flow is now controlled to maintain constant deaerator storage tank level.

For Unit 4, the condenser hotwell level is controlled by gravity makeup from the condensate storage tank and by a condensate pump, and discharge pump line back to the condensate storage tank. Unit 4 deaerator storage tank level is maintained by a level control valve station located on the Unit 4 LP feedwater line upstream of the deaerator and upstream of the common Unit 1-3 LP feedwater transfer line interconnection. Provisions have been made for the future addition of an ASME test flow element in the Unit 4 LP feedwater line upstream of the deaerator in the event that an ASME turbine performance test is conducted for the Unit 4 turbine.

\subsubsection{High Pressure Feedwater System}

The HP feedwater system consists of the new Unit 4 primary process cycle from the Unit $A$ deaerator storage tank outlet to the economizer inlet connection. The HP feedwater systems on Units 1-3 have been retired. (The HP feedwater heaters were retired in place, and the boiler feed pumps have been replaced by condensate unit transfer pumps.)

Condensate from the deaerator storage tank is transferred by two half-capacity boiler feedwater pumps through two stages of HP feedwater heaters. These units heat the feedwater before it enters the circulating $A F B C$ boiler economizer section. 
Individual bypasses are provided around each HP feedwater heater for maintenance purposes. The HP feedwater system also provides spray water for the boiler attemperators. This water comes from the feedwater pump discharge line ahead of the feedwater control valve station. Boller feedwater flow is controlled by a level control valve station, which regulates feedwater flow to maintain a constant level in the boiler steam drum. The feedwater control valve station is located on the discharge side of the boiler feedwater pumps and upstream of the HP feedwater heaters.

Two 50\%-capacity multistage, horizontal-centrifugal, motordriven boiler feed pumps are provided. Automatic-type, minimum flow/check valves are provided on each boiler feed pump discharge line to protect the pump from low flow. The boiler feed pump minimum flow recirculation lines are each individually routed back to the deaerator storage tank.

An ASME test flow element is provided in the HP feedwater line upstream of the boiler economizer inlet connection. Provisions are available for the future addition of an ASME test flow element in the desuperheater spray water supply line, if required. These provisions will allow an ASME turbine performance test to be conducted for the Unit 4 turbine.

\subsection{Plant Water systems}

Included under this heading are all water systems with the exception of the circulating water and fire protection systems. The plant water systems described here are:

- Raw/service water

- Preboiler water treatment

- closed cooling water

- Wastewater

- Condensate storage and transfer

- Potable water.

\subsubsection{Raw/Service Water System}

The plant raw/service water system provides all water to the plant through a distribution system for cooling tower makeup, preboiler water treatment supply, fire protection, dust suppression, plant hose bibs, ash water supply, and miscellaneous plant water services. 
The source of plant water is the San Miguel River, which flows next to the plant. River water flows through four new slotted-screen intake pipes located in the river bed and through a new valve pit into the existing service water pump sump. Two existing service water pumps move rivor water from the sump into the existing plant service water distribution system. A new line is provided off the service water header at the service water pump discharge to the valve pit. This line provides for backflushing of the river bed screen intake pipes when required due to river silt intake. Existing traveling water screens have been removed from the service water pump sump inlet. The new screens were installed to corre-t a problem with high silt in the river water during certain periods of the year.

The service water distribution system consists of an existing main header and some branch headers, both existing and new. The existing main service water header is located underground across the east side of Units 1, 2, and 3, and it extends west and south to an existing water storage tank elevated on a hill approximateiy $60 \mathrm{~m}(200 \mathrm{ft})$ above plant grade. This tank serves as a system head tank and provides for an emergency reserve of fire water. Level switches in the water storage tank actuate the service water pumps.

\subsubsection{Preboiler Water Treatment System}

The preboiler water treatment system extends from the plant service water system through the water treatment filters and makeup demineralizer. This system delivers high-quality makeup water to the condenser hotwell and/or to the condensace storage tank. In addition, the system jncludes all equipment necessary to regenerate the makeup demineralizer, including a demineralizer acid day tank, demineralizer regeneration acid educators, demineralizer causic tank, piping, and valving. The system is comprised of both existing and new items of equipment.

Service water is sukplied to two existing dual-media filters via an existing clearwell and treated water pumps. Service water is also supplied directly via two new dual-media filters that back up the existing filters. Water enters each filter from the top, flows through the filter bed, and discharges out of the bottom to the inlet of two new makeup demineralizer trains. Discharge from the existing filters is also used for the plant potable water supply. Each demineralizer train consists of a strongly acidic cation exchanger, which removes most of the cations in the water and a strongly basic anion exchanger, which removes most of the anions in the water. 
From the operating demineralizer train, the water flows to a mixed bed polisher, which removes the exchangeable ions that remain after treatment by the cation and anion exchangers. The treated water discharge from the mixed bed polisher flows to the Unit 4 condenser hotwell and/or to the Unit 4 condensate storage tank.

\subsubsection{Closed Cooling Water System}

The closed cooling-water system is new and consists of two cl ssed cooling water loops that are provided to cool Unit 4 equipment items. Units 1-3 equipment items are cooled by boosted circulating water. One closed cooling water loop removes useful heat from the boiler bottom ash coolers and recovers this heat by transferring it to the LP feedwater system. The other closed cooling-water loop removes lowlevel heat from various unit 4 equipment items and rejects this heat to the Unit 4 circulating water system.

The ash equipment closed cooling loop is utilized because the LP feedwater system pressure is too high to be used directly in the bottom ash fluidizing-type coolers. Treated condensate is circulated in a closed loop by one of two $100 \frac{0}{\circ}$-capacity ash equipment cooling water pumps to the ash equipment cooling water heat exchanger, which transfers heat to LP feedwater. From this heat exchanger, the cooled water flows in parallel through each of the four bottom ash fluidized coolers and the two screw conveyor coolers where it is heated and returned to the pumps.

The closed cooling-water system cools equipment items requiring higher-quality water and less stringent cooling water temperature than are available directly from the circulatingwater system. Treated condensate is circulated in a closed loop by one of two $100 \%$-capacity closed cooling water pumps to two $100 \%$-capacity closed cooling water heat exchangers. These exchangers transfer the low-level waste heat to the Unit 4 circulating water system. From these heat exchangers, the cooling water flows in parallel to cool the following equipment:

- The generator seal oil.

- The instrument air compressor (inter, after, bleedoff, and jacket coolers).

The water sample panel.

The turbine-generator ( $T-G)$ electro-hydraulic control unit. 
- The boiler teedwater pumps (lube vil and seal water coolers).

- The primary air fan lube oil coolers.

- The secondary air fan bearings and the bottom ash cooling fan bearings.

These two closed cooling water loops are interconnected in that they share a common makeup, closed cooling water head tank, and chemical feeder pot. Corrosion inhibitor is fed from the chemical feeder pot to the pump suction lines in each loop. Closed cooling water makeup is treated condensate supplied from the Unit 4 condensate pump discharge and is controlled by the level in the common closed cooling water head tank. Makeup condensate can also be added to the closed cooling water system by the Unit 4 condensate transfer pump when the condensate pumps are not operating. The head tank also provides protection against surges and thermal changes. The head tank is actually a pipe enlargement at the top of a standpipe.

\subsubsection{Wastewater System}

The plant wastewater system includes the plant high-quality, low-quality, and sanitary drain collection and disposal

facilities. Other than a few new drains, trenches, a septic tank and leach field, and an oil/water separator for the new Unit 4 , the entire system was already in place.

High-quality plant drains, including cooling tower blowdowns, and storm drains, flow by gravity to a cooling tower blowdown (higher quality nolding) pond. This holding pond is lined. The cooling tower blowdown pond provides temporary retention to allow solids to settle out. The cooling tower blowdown pond discharges to the San Miguel River.

Low-quality plant drains, including plant floor and chemical drains, are routed to a lower quality holding pond. Plant drains pass through an oil/water separator prior to entering the lower quality holding pond. This pond is unlined and has no outlet flow; seepage and evaporation equals the in-flow.

Sanitary wastes are routed to septic tanks (one replaced and two new) and leach fields. 


\subsubsection{Condensate Storage and Transfer}

The condensate storage and transfer system consists of condensate storage tanks, transfer and deaerator feed pumps, and their associated piping. A new conciensate storage tank and transfer pump are provided for Unit 4. This equipment is intertied to the existing Unit 1-3 condensate storage and transfer system.

The purpose of the condensate storage and transfer system is to store a reserve of high-purity treated water and deliver it for use by the plant steam/water cycle and other plant support systems, as needed. The source of treated water is the preboiler water treatment system.

Unit 4 condensate is stored in a lined aluminum storage tank with a capacity approximately equal to one boiler fill.

On each unit, condensate is gravity fed from the condensate storage tank to the condenser hotwell. This is a manual operation on Units 1-3, as condenser hotwell level is controlled by regulating the LP feedwater flow from the hotwell to the deaerator. For Unit 4, condensate makeup to the condenser hotwell is automatically controlled by hotwell level. On Unit 1-3, condensate can also be transferred to the deaerator or to another condensate storage tank by deaerator feed pumps. The Unit 4 condensate transfer pump is provided to transfer condensate from the Unit 4 condensate storage tank to the existing Units $1-3$ condensate storage tanks, the plant heating system, the chemical feed system, and the closed cooling water system.

In addition to receiving makeup condensate from the preboiler water treatment system, the condensate storage and transfer system also receives excess condensate from the steam/water cycle on each unit, from the condensate pump discharge (hotwell. high level dump), and deaerator overflow or dump (high level). Condensate is also returned to the storage and transfer system from the Unit 4 water sample panel, and from the Units 1-3 heating system.

\subsubsection{Potable water System}

The potable water system supplies drinking-quality, filtered, and chlorinated service water throughout the plant.

The source of potable water is the downstream side of the preboiler water treatment system, specifically following the dual media filters. 
The existing potable water distribution system was simply extended to supply potable water to the new control room and maintenance shop. Potable water is distributed to toilets, wash basins, and drinking fountains. Electric hot-water heaters provide hot water to the wash basins.

\subsection{Circulating water systam}

The circulating water system consists of two independent evaporative cooling cycles that serve as the heat sink for the plant power cycle and provide cocling for major equipment items. An existing circulating water system commonly services Units 1-3, and a new circulating water system is provided for Unit 4.

\subsubsection{Units $1-3$ Circulating water System}

The Units 1-3 circulating water system transfers low-level waste heat from the Units $1-3$ condensers, turbine gland leakoff condensers, turbine oil coolers, and generator air coolers to the Units 1-3 cooling tower. The cooling tower releases the waste heat to the atmosphere primarily by evaporative cooling and, secondarily, by sensible heat transfer to the atmosphere. The major system equipment includes the cooling tower, the circulating water pumps, and the cooling water (booster) pumps.

Units 1-3 circulating water is pumped from the cooling tower water hisin by three common, 33\%-capacity, vertical-shaft, wet pit, circulating water pumps. From the discharge of the circulating water pumps, the circulating water flows through an underground pipeline to the plant building. The flow splits and goes simultaneously to both the tube sides of the Units 1-3 condensers and to the cooling water (booster) pumps.

Three common, 33\%-capacity, cooling water (booster) pumps are provided for Units $1-3$ to boost the circulating water pressure. This water cools the turbine gland steam leakoff condenser, the turbine lube oil coolers, and the generator air coolers on all three existing units. Due to age and condition, the original three cooling water booster pumps were replaced with new pumps. The boosted cooling water flow through the turbine oil coolers and the generator air coolers on each unit is modulated by a temperature control valve.

The heated circulating water from the Units 1-3 condensers and equipment coolers then merges back into a single underground pipeline and flows to the Units 1-3 cooling tower. At the cooling tower, the circulating water flow is distributed by headers along the top of the tower. The warm circulating water cascades down over the cooling tower fill, releasing 
heat to the atmosphere, and is collected in the cooling tower basin. The cooled water then flows back to the circulating water pumps, completing the cycle.

A cooling tower, cold weather bypass is provided to return circulating water flow directly to the cooling tower basin. The cooling tower bypass is used when Units 1-3 are out of service, or at low loads during cold ambient conditions to prevent tower freezing and icing buildup.

A portion of the Units 1-3 circulating water flow is blown down to maintain acceptable chemical concentrations in the circulating water. Blowdown flow is taken upstream of the cooling tower and is routed to the cooling tower blowdown pond. Blowdown flow control is automatically modulated by blowdown conductivity. In addition to blowdown, circulating water is continuously lost as couling tower evaporation and drift which must be continuously made up. Makeup water is provided from the service water system to the cooling tower basin and is controlled to maintain a constant basin water level.

\subsubsection{Unit 4 Circulating Water System}

The Unit 4 circulating water system transfers waste heat from the Unit 4 condenser, turbine lube oil coolers, generator hydrogen cooler, and closed cooling water heat exchangers to the Unit 4 cooling tower. The cooling tower releases the waste heat to the atmosphere primarily by evaporative cooling and secondarily by sensible heat transfer to the atmosphere. The major system equipment includes the cooling tower and the circulating water pumps.

Unit 4 circulating water is pumped from the cooling tower water basin by two horizontal shaft centrifigal circulating water pumps. From the discharge of the circulating water pumps, the circulating water flows through a single underground pipeline to the Unit 4 turbine building. Here the flow splits and goes simultaneously through the tube sides of the condenser, turbine lube oil coolers, generator hydrogen coolers, and the closed cooling water heat exchangers. The circulating water flow through the turbine lube oil coolers, hydrogen coolers, and closed cooling water heat exchangers is modulated by butterfly temperature control valves.

The heated circulating water then merges back into a single underground pipeline and flows to the cooling tower. At the cooling tower, the circulating water flow is distributed by headers along the top of the tower. The warm circulating water cascades down over the cooling tower fill, releasing 
heat to the atmosphere, and is collected in the cooling tower basin. The cooled water then flows past a chlorine diffuser back to the circulating water pumps, completing the cycle.

A cooling tower cold weather bypass also is provided by bypass return circulating water flow from Unit 4 directly to the cooling tower basin. The cooling tower bypass is used when the plant is out of service or at a lo load during cold ambient conditions to prevent tower freezing and icing buildup. The bypass is sized to pass $18.9 \mathrm{~m}^{3} / \mathrm{min}(5,000 \mathrm{gpm})$ flow of circulating water.

A portion of the Unit 4 circulating water flow is blown down to maintain acceptable chemical concentrations in the circulating water. Blowdown flow is taken upstream of the cooling tower and is routed to the cooling tower blowdown pond. Blowdown flow control is automatically set by a flow recorder based on unit load index with trim from circulating water conductivity. In addition to blowdown, circulating water is continuously lost as cooling tower evaporation and drift which must continuously be made up. Makeup water is provided from the blowdown flash tank drain flow and from plant service water. Service water makeup is introduced to the cooling tower basin. Its flow is controlled to maintain a constant cooling tower basin water level.

Both circulating water systems are serviced by a common cooling tower chemical feed system, which is discussed later in this section.

A small intertie is provided between the existing Units 1-3 and the new Unit 4 circulating water systems. This intertie enabled the Unit 4 closed cooling water heat exchangers, turbine lube oil coolers, and generator hydrogen coolers to be used during initial Unit 4 commissioning activities prior to the scheduled completion of the Unit 4 cooling tower construction.

\subsection{Condenser and Accessories}

The condenser and accessories system includes the condenser and the condenser air-removal equipment. Identifical condensers and accessories exist for each of the three existing Units (1-3). A new condenser and condenser accessory equipment are provided for Unit 4. The following description applies for both the existing Units $1-3$ and the new Unit 4 condensers.

For each unit turbine exhaust, steam is condensed by the condenser. The steam is condensed on the shell side of the condenser by exchanging its waste lieat to cooler circulating water 
flowing through the tubes of the condenser. The Unit 1-3 condensers are serviced by a common existing circulating water/cooling tower system. The new unit 4 condenser is serviced by a new circulating water/cooling tower system. The high-quality condensed steam or condensate flows by gravity to a condenser hot well, from where the condensate pumps move it to the LP extraction feedwater heaters on each unit.

The condenser for each unit also serves as a collection point for various high-purity cycle vents and drains including:

- LP feedwater vents and drains

- HP feedwater alternate drains for Unit 4 only

- Turbine drains

- Gland steam condenser

- Steam jet air ejector drains.

The condenser vacuum on each unit is established by a priming jet (or hogging jet on Units 1-3) air ejector, which uses auxiliary steam (turbine throttle steam for Units 1-3) to induce or draw a vacuum on the condenser prior to starting the turbine. During normal operation, condenser vacuum is maintained by a dual-stage, steam jet air ejector to remove air and other noncondensable gases from the condenser. Auxiliary stearn (turbine throttle steam for Units 1-3) is also used to operate the steam jet air ejectors. The steam jet ejector induction steam flow and heat are condensed with LP feedwater flow and drained to the condenser for recovery.

\subsection{Chemical Feed Systems}

The chemical-feed systems include the following subsystems:

- Feedwater chernical-feed system

- Boiler chemical-feed system

- Cooling tower chemical-feed system

- Closed cooling tower chemical-feed system

- Water sampling and monitoring system.

These subsystems consist of new and/or existing equipment items which are described in the following sections. 


\subsubsection{Feedwater Chemical Feed System}

A new feedwater chemical-feed system is provided for Unit 4. This system pumps a solution of amine and condensate to the LP feedwater line on the discharge side of the condensate pumps. It also pumps a solution of hydrazine and condensate to the LP feedwater line upstream of the deaerator inlet. This system includes two solution tanks, one for amine and one for hydrazine. Each system is complete with a mixer, three reused existing positive displacement metering pumps - one each for amine and hydrazine - and a common spare. Condensate for filling the tank is provided from the condensate transfer pump.

\subsubsection{Boiler Chemical Feed System}

A new boiler chemical-feed system is provided for the new circulating AFBC boiler. This system pumps a solution of mo o-, di- or tri-sodium phosphate and condensate to the AFBC boiler steam drum. It consists of a solution tank with mixer and condensate inlet connection, and two diaphragm-type, positive displacement metering pumps, ore of which is an installed spare.

\subsubsection{Cooling Tower Chemical Feed System}

The cooling tower chemical-feed system is an existing system with new components added for the Unit 4 cooling tower. The system is common for both the existing and the new cooling towers. This equipment includes the cooling tower chlorination, chemical feed, and acid feed systems.

The circulating-water systems are treated with chlorine solution on a periodic treatment cycle to prevent biological fouling in the circulating-water systems. Chlorine bottles supply chlorine gas to two chlorinators (one existing and one new chlorinator) for the existing and new cooling towers, respectively. For the new cooling tower, the chlorine gas enters an ejector where it mixes with service water to form a chlorine solution. This solution is fed to a chlorine diffuser located in the cooling tower basin. For the existing cooling tower, chlorine gas is mixed with service water in an ejector and is introduced into the circulating water line on the discharge side of the circulating water pumps.

The cooling towers are treated with a scale-inhibitor solution. A new chemical solution tank is used to mix the scale inhibitor with service water. Three positive displacement metering pumps, two existing and one new pump, transfer the 
scale-inhibitor solution to the cooling tower basins in proportion to cooling tower blowdown. An existing pump is a common spare for both cooling towers.

Sulfuric acid (delivered by truck) is received in the existing cooling tower acid tank. Three positive displacement metering puinps, two existing and one new pump, feed acid to control circulating water pH. One pump is a common spare for both cooling towers.

\subsubsection{Closed Cooling Water Chemical Feed System}

Corrosion inhibitor is fed from a new chemical feeder pot located between the closed cooling water pumps, discharge and suction headers. It is also connected to the suction side of the ash equipment cooling water pumps. The chemical feeder is included as part of the closed cooling water system.

\subsubsection{Water Sampling and Monitoring System}

A new water sample panel provides primary and secondary sample cooling, sample pressure and flow control, and sample analysis. Cooling water is used for primary sample cooling of high-temperature sample streams. Raw water is used for secondary sample cooling via a heat exchanger. From the sample panel, the sample streams are returned to the Unit 4 condensate storage tank and/or to plant drains.

Samples from the following locations are routed to the water sample panel (sample analysis is listed in parenthesis):

Boiler water (specific conductivity, $\mathrm{pH}$, silica, and grab sample).

- Boiler steam drum saturated steam (cation conductivity, sodium, and grab sample).

- Main steam (cation conductivity, sodium, and grab sample).

- Economizer inlet (dissolved oxygen, specific conductivity, sodium, silica, and grab sample).

Unit 4 condensate pump discharge (dissolved oxygen, cation conductivity, and grab sample).

- Existing Unit 1-3 deaerator outlets (dissolved oxygen and grab sample). 
- Existing Unit 1-3 condensate systems (cation conductivity, dissolved oxygen and grab samples).

- Preboller water treatment mixed bed feed and discharge (silica and grab sample).

A new independent sample panel system is provided for sampling, analyzing, and recording both circulating water chemistry and blowdown flow from both circulating water systems.

\subsection{Miscellaneous Mechanical Equipment}

Miscellaneous mechanical equipment systems include:

- Heating, Ventilating and air conditioning (HVAC) systems

- Compressed air systems

- Cranes and hoists

- Lube oil storage and conditioning

- Fire protection

- Fuel gas supply.

These are discussed in the following subsections.

\subsubsection{HVAC Systems}

The HVAC systems provide for the heating, ventilating, and air conditioning of the plant facilities. The systems include both new HVAC systems to serve the new Unit 4 facilities and existing plant HVAC systems that serve the Units 1-3 plant building.

HVAC is provided for the following plant areas:

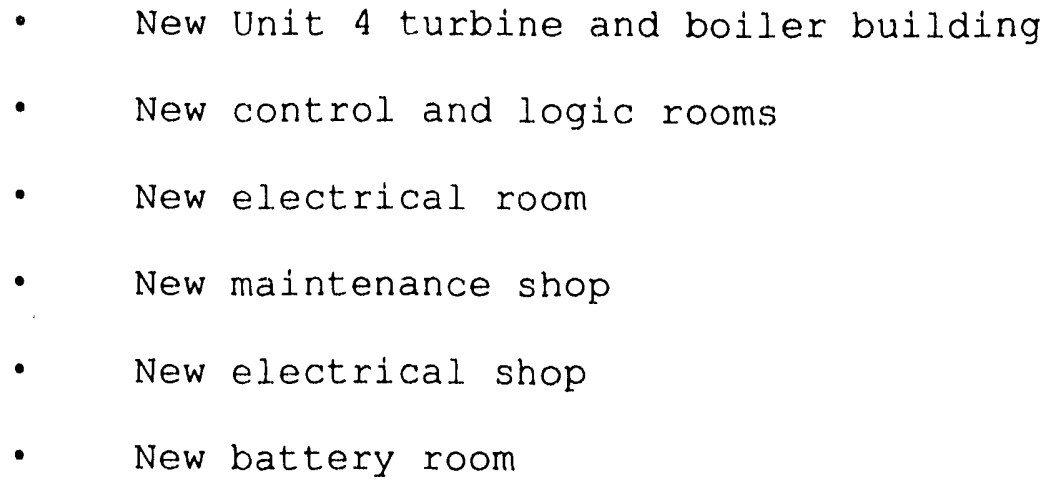


- New variable-speed control equipment room

- New elevator machinery room

- New outlying buildings

- Existing turbine and boiler building.

\subsubsection{New Turbine and Boiler Bullding HVAC}

The design inside temperature is $8^{\circ} \mathrm{C}\left(15^{\circ} \mathrm{F}\right)$ minimum temperature in winter. Reversible power vontilators and gravity air movers are installed on the boiler room roof. Windows are installed in the turbine room walls at the grade and operating floor levels. Steam unit heaters are installed in the lower areas along exterior walls to heat incoming air at the rate of one-half total air change per hour.

For summer operation, the power roof ventilators and gravity air movers are used in conjunction with the circulating AFBC boiler combustion air fan (PA and SA fan) suctions to remove hot air accumulated at the top of the boiler building. This volume has been calculated to substantially exceed boiler combustion air requirements. Cooling air is admitted through both doors and windows. Air flow is created by the boiler area negative pressure created by the roof ventilators, boiler combustion air fans, and boiler room stack effect.

For winter operation, gravity air movers, doors, and windows are closed. Power roof ventilators are operated in reverse to provide boiler combustion air requirements, thereby minimizing negative pressure in the building and the attendant air infiltration. Some negative pressure exists because of the stack effect in the boiler area. Steam unit heaters are located in the lower areas of the turbine and boiler rooms to provide heating requirements. These heaters have individual thermostats to energize their fan. Roof-mounted gravity air mover, damper actuators are controlled by manual off-on switches located in the control room. Roof-mounted power ventilators have off-on reverse switches located in the control room.

A $2.1 \mathrm{~kg} / \mathrm{cm}^{2}$ (30 psig) heating steam is provided from the auxiliary steam system from either Unit 4 turbine deaerator extraction or from the auxiliary boiler. A two-pipe arrangement is used, one pipe to supply steam to the unit heaters and the second pipe to return the condensate to the heating system deaerator receiver. The condensate is 
then pumped by one of two full-capacity heating system condensate pumps back to the Unit 4 main cycle deaerator or to the auxiliary boller. The heating system deaerator and heating system condensate pumps are provided new with Unit 4. However, the heating system deaerator and condensate pumps were purchased as a used-equipment package.

\subsubsection{New Control and Loqic Rooms HVAC}

Design room temperatures are $21^{\circ} \mathrm{C}\left(70^{\circ} \mathrm{F}\right)$ in winter and $26^{\circ} \mathrm{C} 78^{\circ} \mathrm{F}$ ) in summer. Relative humidity is not to exceed 50\%. Positive pressure is maintained in each room. Two duplicate 100\%-size, atr-handling units are used, each equipped with filters and direct expansion coils. Supply and return ducts convey air to and from the control and logic areas. Low-velocity/low-pressure loss, air distribution ducts are used. Duplicate, roof-mounted, aircooled condensers and compressors are provided. Electric duct heaters are utilized for final control of temperature in each room. Makeup air is provided to the suction side of the air handling units from outside.

Controls use makeup air, direct expansion coils, and duct heaters as required to sat sfy room temperature. An air conditioning system control panel is located at each airhandling unit with a manual off-auto switch to allow individual units to be operated for check-out or maintenance. When either switch is in the "auto" position, the control system automatically operates the HVAC equipment. The control of the redundant system is arranged in such a way that it allows either system to be used as the main system. Electric duct heaters are controlled by room thermostats.

\subsubsection{New Electrica 1 Room HVAC}

No space heating is provided for winter. Design summer temperature is $8^{\circ} \mathrm{C}\left(15^{\circ} \mathrm{F}\right)$ above outdoor ambient. A supply air fan provides ventilation and pressurization air, and an exhaust lover is provided to exhaust the air.

A thermostat with a hand-off switch override is supplied to control the fan. The fan shutter operator and exhaust lower louver operator are interlocked with fan operation to open when the fan motor is energized and to close when the fan motor is deenergized. 


\subsubsection{New Maintenance Shop HVAC}

Maintenance area ventilation is provided by a wall-mounted supply fan. The fan provides six air changes per hour. The maintenance area heating requirement is provided by steam unit heaters. Design temperature is $18^{\circ} \mathrm{C}\left(65^{\circ} \mathrm{F}\right)$ for winter. The ventilation fan is controlled by a manual onoff switch. Unit heaters are controlled by individual. thermostats.

The maintenance office is provided with a window-type combination air conditioning and heating unit. Design temperature is $27^{\circ} \mathrm{C}\left(80^{\circ} \mathrm{F}\right)$ for summer and $21^{\circ} \mathrm{C}\left(70^{\circ} \mathrm{F}\right)$ for winter in the office.

\subsubsection{New Electrical Shop HVAC}

Ventilation and heating requirements are provided by a wall-mounted supply fan and steam unit heaters, respectively. The ventilation fan is controlled by a manual onoff switch. The fan provides six air changes per hour. Unit heaters are controlled by individual thermostats. The winter design temperature is $18^{\circ} \mathrm{C}\left(65^{\circ} \mathrm{F}\right)$.

\subsubsection{New Battery Room HVAC}

A supply grill and exhaust fan are used for ventilation purposes. A minimum of four air changes per hour are provided. The fan is controlled by a manual on-off switch. The room temperature is maintained above $25^{\circ} \mathrm{C}$ $\left(77^{\circ} \mathrm{F}\right)$ as much of the time as possible.

\subsubsection{New Variable-Speed Control Equipment Room HVAC}

This room contains the variable-frequency control equipment for the AFBC boiler PA, SA, and ID fan drives. The air conditioning equipment required for this room is provided by the AFBC boiler supplier and is included as part of the boiler air and gas system.

\subsubsection{New Elevator Machinery Room HVAC}

Ventilation is provided as required.

\subsubsection{New Outlying Buildings HVAC}

These buildings include the new stack monitoring equipment, cooling tower electrical, cooling tower chemical, limestone electrical, and the ash blower buildings. These buildings are ventilated, and some are heated. Electric 
unit heaters are used to heat the stack monitoring equipment, cooling tower chemical, limestone electrical buildings to $13^{\circ} \mathrm{C}\left(55^{\circ} \mathrm{F}\right)$. The stack monitoring equipment building is heated and cooled by a packaged heat pump. Building ventilation for each of these buildings, except the stack monitoring equipment building, consists of a wall-mounted supply fan (complete with inlet shutter) and a motor-operated wall exhaust damper. The building ventilation fan starts and the dampers open when the building temperature is $35^{\circ} \mathrm{C}\left(95^{\circ} \mathrm{F}\right)$ and shutoff at $27^{\circ} \mathrm{C}$ $\left(80^{\circ} \mathrm{F}\right)$.

\subsubsection{Existing Turbine and Boiler Building HVAC}

The existing plant building heating system utilizes 1.5 $\mathrm{kg} / \mathrm{cm}^{2}$ (15 psig) steam provided from the new auxiliary steam system. This system is designed with sufficient capacity to supply the existing building heating requirements. Cross-connections are made between new and existing steam supply and condensate return lines.

\subsubsection{Compressed Air Systems}

The instrument and service air systems supply plant instrument and service compressed air for all plant requirements. The systems consist of a combination of new and existing equipment and distributi 1 piping.

Instrument air is supplied by a new two-stage, oil-free, rotary screw compressor complete with an electric drive motor, intercooler, bleed-off ccoler, inlet filter/silencer, control and relief valves, control panel, and instrumentation all mounted on a common skid. The instrument air compressor supplies $7.7 \mathrm{~kg} / \mathrm{cm}^{2} / 46^{\circ} \mathrm{C}\left(110 \mathrm{psig} / 115^{\circ} \mathrm{F}\right)$ air to a new instrument air skid. The instrument air skid includes an air receiver, a dryer prefilter, a desiccant-type regenerative air dryer, and a dryer afterfilter. Compressed air supply to the instrument air skid is backed up by service air. From the instrument air skid, the dried and filtered instrument air is distributed to both the new Unit 4 circulating AFBC boiler, turbine-generator, baghouse, ash system, coal handling and limestone areas, and to the existing Units 1-3 instrument air distribution network via the existing instrument air receiver. The existing instrument air compressors and air dryer have been retired.

Service air is supplied by two single-stage, oil-flooded type, rotary-screw compressors. One compresior is normaliy operating in an on-off mode and the other ccnpressor is a spare in standby mode. These compressors were previously utilized for 
construction purposes. The service air compressors discharge air at $7 \mathrm{~kg} / \mathrm{cm}^{2}(100 \mathrm{psig})$ and $43^{\circ} \mathrm{C}\left(110^{\circ} \mathrm{F}\right)$.

The service air compressor discharge flow passes through an oil scrubber and filter and enters a service air receiver. From the service air receiver, the service air is distributed to the Unit 4 boiler and turbine areas: the new instrument air skid via control and check valves to back up the instrument air compressor, and the existing plant service air system. The existing plant service air system includes two compressors, a dryer, and a receiver. The existing service air compressors are available for standby duty.

\subsubsection{Cranes and Hoists}

The Nucla station has two turbine bay cranes. An existing crane services Units 1-3, which share a common turbine bay. A new crane services the Uni: 4 turbine bay. The arrangement of the larger Unit 4 did not permit the new turbine-generator to be situated as an extension of the existing turbine bay. The lifting service requirements for the Unit 4 turbine generator also exceeded the capacity of the existing turbine bay crane.

A boiles area maintenance hoist and an elevator are located in the Unit 4 boiler room area. The elevator is situated to serve the entire plant. The existing plant building does not have an elevator.

\subsubsection{Lube Oil Storage and Conditioning}

Units 1-3 turbine-generator lube oil systems are serviced by two existing centrifuge-type lube oil conditioning units. One unit commonly serves Units 1 and 2 alternately, and the other unit services Unit 3 . Lube oil storage tanks are not provided for the Units $1-3$ turbine-generators.

A complete lube oil storage and conditioning system is provided for the Unit 4 turbine-generator. The system consists of two lube oil storage tanks (one "clean" and one "dirty," each sized to hold one complete charge of I'-G lube oil); two lube oil transfer pumps (one to transfer lube oil to/from storage and one to transfer turbine reservoir lube oil to the conditioner unit); a filtering-type lube oil conditioner unit; a waste oil sump; a waste oil sump pump; and a waste oil tank. 


\subsubsection{Fire Protection}

Fire protection for the Nucla Station consists of a fire water syste (using the service water supply), carbon dioxide gas systems for each generator, and a stand-alone deluge system for the propane storage tank.

The existing plant uses fire water supply directly from the plant service water header network. The fire water supply for Unit 4 is service water boosted by a new fire booster pump and a nes pressure maintenance pump. The Unit 4 fire water booster and pressure maintenance pumps are required because of the significantly greater height of the new AFBC boiler structure. The fire water distribution system for both the existing structure and new unit addition consists of fire hydrants, deluge systems (for the transformers), preaction sprinkler, and coal-dust suppression (explosion prevention) systems. Pressure is maintained in the service water header network supplying fire water by the elevated service water storage (head) tank which also serves as the fire water storage tank. Pressure is continuously maintained in the Unit 4 fire water header by a small-capacity, pressure maintenance pump which cycles on and off to maintain header pressure. The fire booster pump starts only if the maintenance pump fails to maintain header pressure (causing a surge in flow).

Accessory cabinets are provided that contain hose reels, hose, nozzles, hose connectors, axes, and miscellaneous firefighting equipment. Hand-held fire extinguishers are placed at various locations throughout the plant.

The $\mathrm{CO}_{2}$ systems for Units $1-3$ are provided for generator fire protection only (the generators are air cooled). The Unit 4 generator $\mathrm{CO}_{2}$ system is for both fire protection and generator hydrogen purging (fire prevention).

A stand-alone deluge fire protection system is provided for and as part of the Unit 4 propane storage tank.

\subsubsection{Fuel Gas Supply}

Propane is used for plant fuel gas. The propane fuel gas supply includes a truck unloading station, a used and reconditioned storage tank, used and reconditioned propane vaporizers, a propane supply pump, a plant gas supply line, and system wiring and controls. The propane fuel system is provided as part of the new Unit 4 installation, and it supplies fuel gas to both the auxiliary heating boiler and the $A F B C$ boiler startup and duct burners. 
Colorado-Ute's original plan was to contract with the local gas company to run a natural gas supply line into the Nucla plant from about seven miles away. The gas burners on both the AFBC and auxiliary boilers were originally sized for natural gas. However, the cost to install a propane system was significantly less than for a natural gas line, and the energy costs were very close to being equivalent. Thus, Colorado-Ute elected to install a propane gas supply system at the Nucla Station. The only change required to switch from natural gas to propane for the various burners was to install smaller burner orifices to correct for the higher heating value of the propane fuel (approximately 2.5 times higher than natural gas on a volumetric basis). 
Section V. Turbine-Generator and Balance-of-Plant Electrical Equipment and Systems

The turbine-generator and balance-of-plant electrical equipment includes the steam turbines, generators, the main power transformers, auxiliaries and bulk electrical materials needed by the plant to supply electrical energy. Description of these plant support equipment, facilities, and systems are also included in this section. Turbine-generator and balance-of-plant electrical equipment data is included in Appendices $A$ and $B$.

\subsection{Turbine-Generator}

The turbine-generator system includes the three existing turbinegenerator units (1-3), which have been modified and refurbished and the new. Unit 4 turbine-generator, complete with accessories and a number of integral turbine-generator subsystems.

\subsubsection{Existing Unit $1-3$ Turbine-Generators}

The three existing Unit 1-3 turbine-generators are each identical 11,500 $\mathrm{kW}$ American Institute of Electrical Engineers (AIEE)-ASME preferred standard machines. The turbines, manufactured by De Laval Steam Turbine Company, are 3,600 rpm, multistage, non-reheat, condensing units, directly coupled to the generators, manufactured by Electric Machinery Company. Throttle steam conditions are $42 \mathrm{~kg} / \mathrm{cm}^{2}$ (600 psig), $441^{\circ} \mathrm{C}$ $\left(825^{\circ} \mathrm{F}\right)$. Four stages of uncontrolled extraction heat the feedwater. The highest pressure extraction, which originally supplied a single-stage high-pressure (HP) feedwater heater on each unit, has been capped off as part of the plant modification. The HP feedwater heaters have been retired and the lowpressure (LP) feedwater from the Unit 1-3 deaerators is now pumped to the new Unit 4 deaerator. The turbines are each rated at $12,650 \mathrm{~kW}$ at $3.8 \mathrm{~cm}(1.5 \mathrm{in}) \mathrm{Hg}$ exhaust pressure.

The generators are each synchronous 3,660 rpm, three-phase, 60 -hertz units with air-cooled stator and rotor. The generators are each rated at 13,529 KVA at a 0.85 power factor. Because of their age, the generators had relatively high leakage rates and rewinding them was considered. Due to project budget constraints, generator rewinding was postponed to a later date. New varnish was applied to the generators which substantially improved their leakage rates.

The existing turbine-generators each include the following major subsystems and accessories:

- Turning gear 
- Shat-driver oil fump

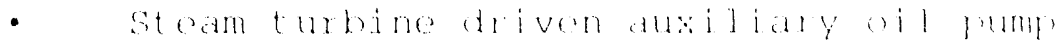

- Combined trip and throt la valve

- do generitor antior

- Turbine governor.

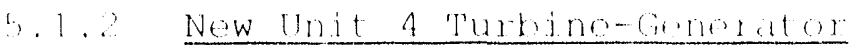

This turbinowenerator mit is a single horiantal ablate, steam-driven, revolving-tield, eloctrianl gonorat ing mit.

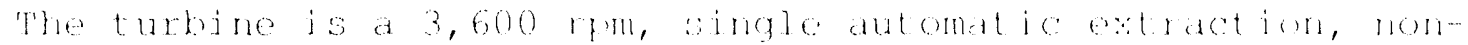
rehod condensing unit mounted in a single assing and mamba-

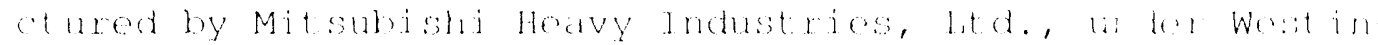

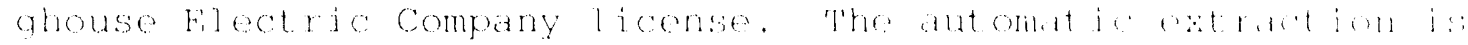

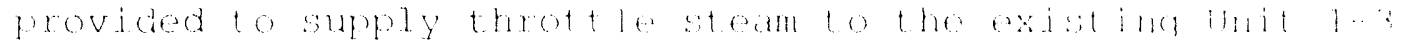

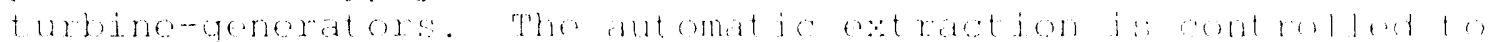

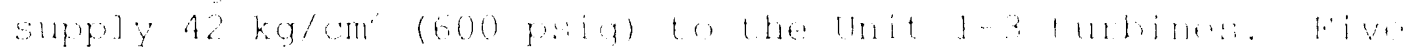

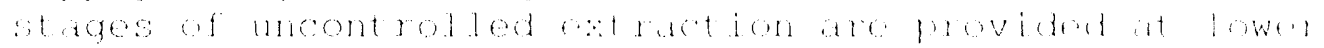

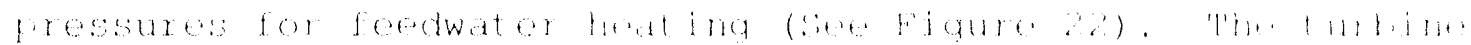

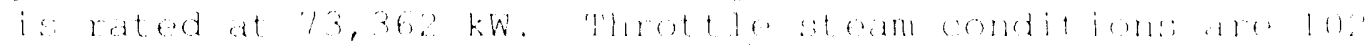

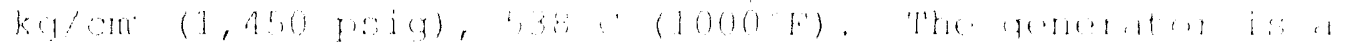

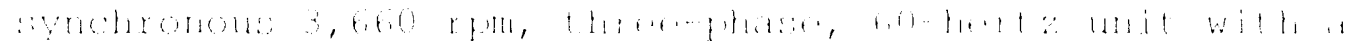

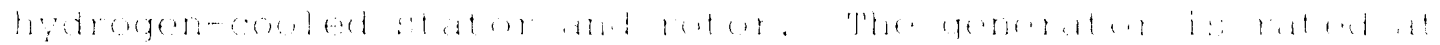

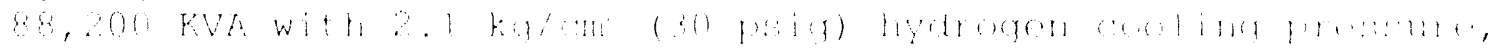

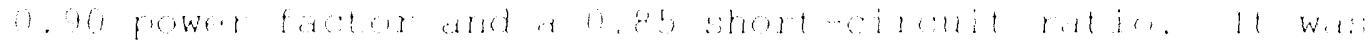

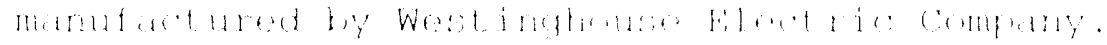

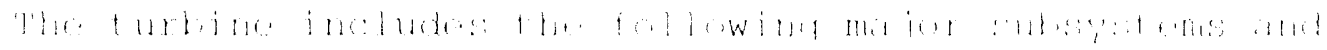
areasengias:

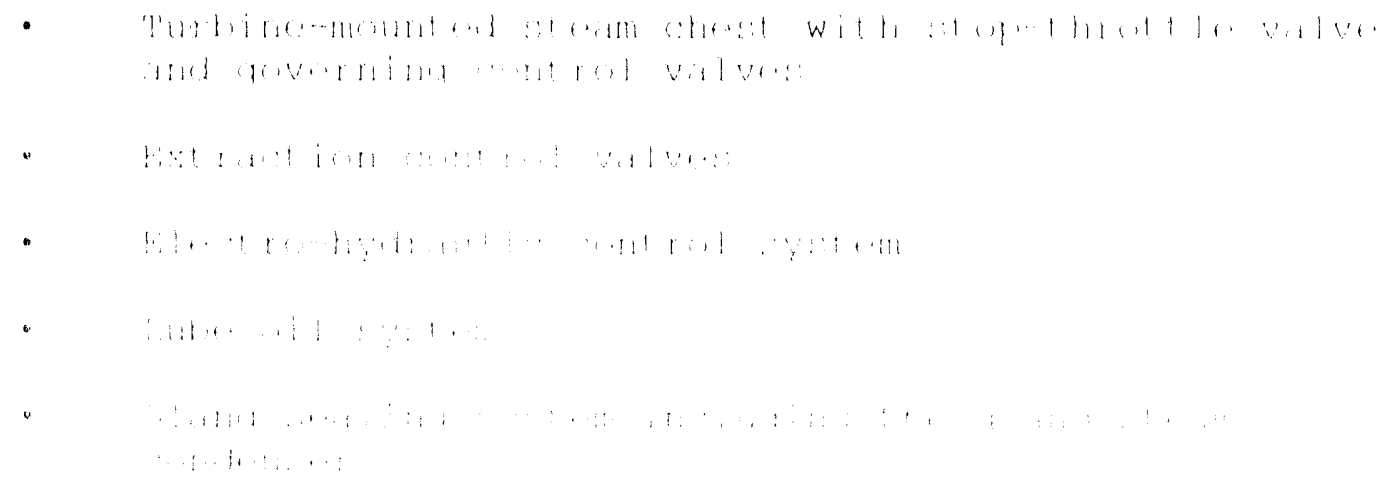



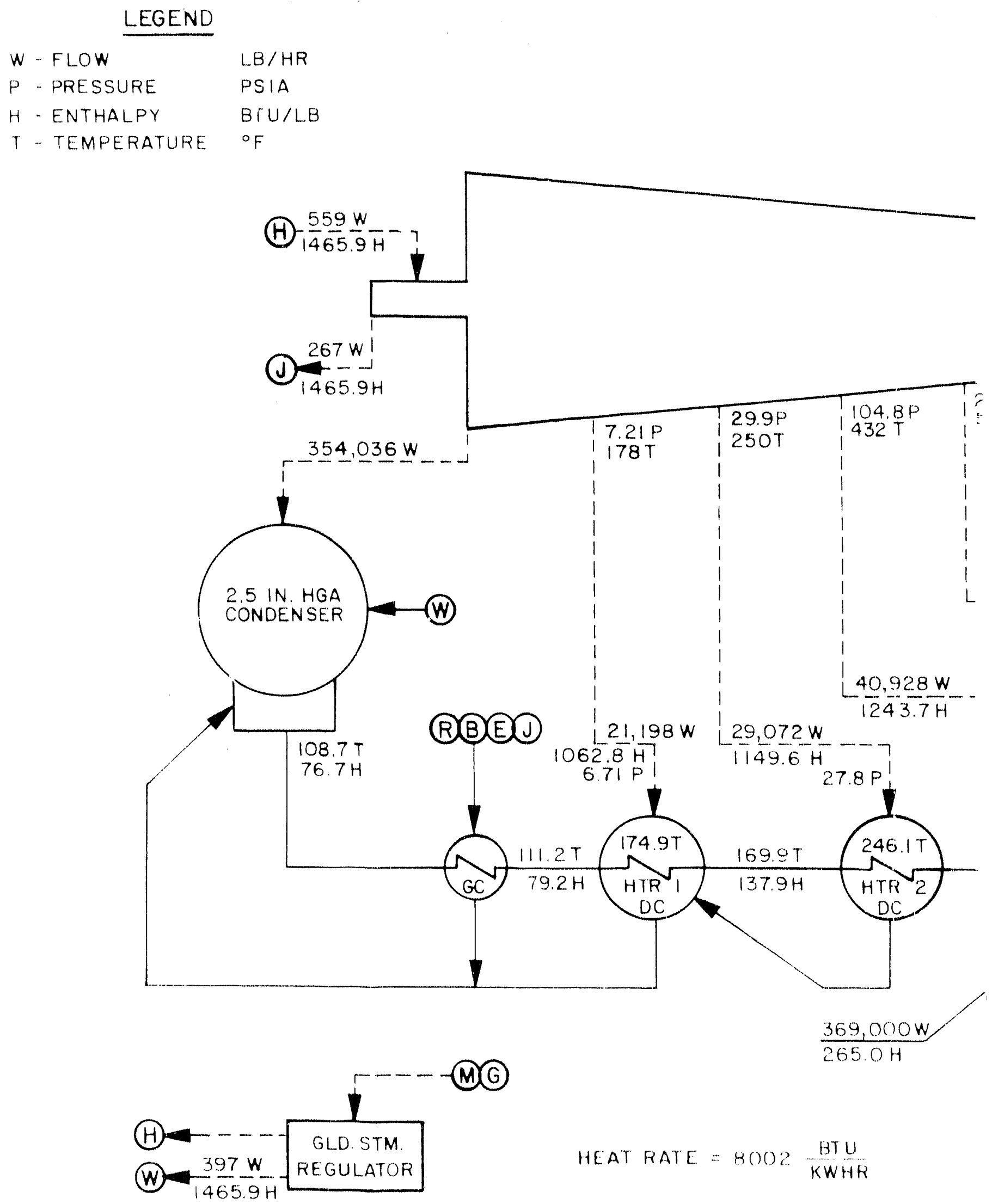


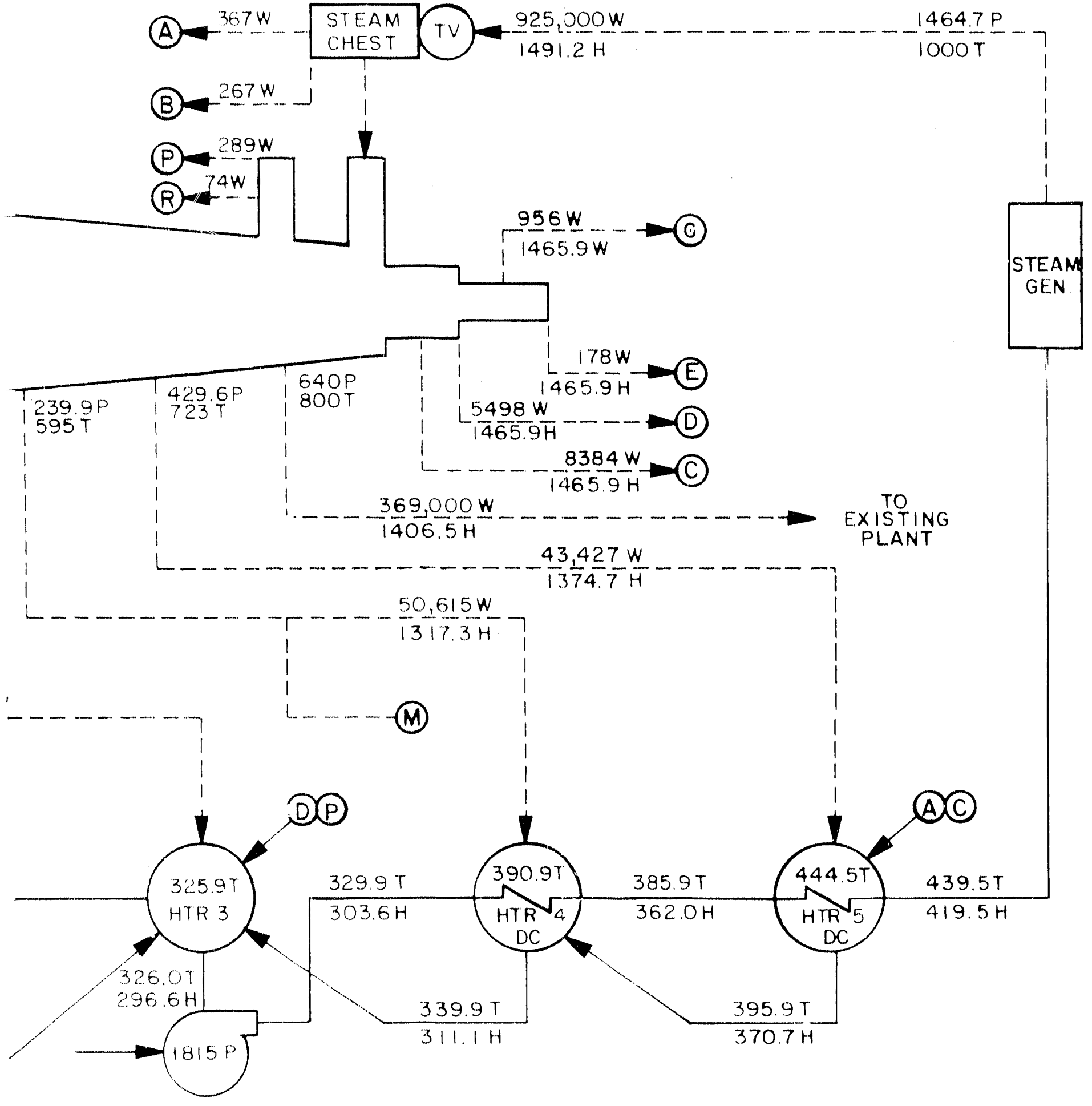

FIGURE 22 
- Turning gear

- Turbine provective devices

- Turbine supervisory instruments

- Rotor-grounding device

- Insulation and lagging.

The generator includes the following major subsystems and accessories:

- Hydrogen-cooling system

- $\quad$ Static-excitation system

- Generator field discharge resistor

- Six high-voltage bushings with terminals

- Sixteen bushing current transformers

- Temperature detectors

- Seal oil system.

The electrical sections of the generator (excitation system, etc.) constitute part of the generator and main power transformer system.

\subsubsection{Turbine Gland Seal System}

The turbine gland seal system seals the turbine casing shaft penetrations between the turbine shell/exhaust hood and the atmosphere to prevent both leakage of air into the condenser and blow out of steam into the turbine room. The gland sealing system is provided as part of the turbine unit.

Each of the two turbine gland-shaft seals consists of labyrinth-type packing rings to restrict the flow of steam and air to a minimum. During startup, main steam is the source of gland steam. During normal operation, steam leakoff from the high pressure end (No. 1 gland) serves as the source of glarid steam for the exhaust hood (No. 2 gland). Gland steam leakoff pressure is regulated by a pressure control valve that exhausts excess gland steam to the highest pressure, feedwater heater, extraction steamline. Leakoff gland sealing steam and air in-leakage is 
routed to the gland steam condenser which condenses the steam, returns the condensate to the condenser, and exhausts non-condensable gases (air) to the atmosphere via one of two 100\%-capacity exhauster fans.

\subsubsection{Turbine Lube Oil system}

The function of the turbine lube oil system is to provide for the lubrication of turbine and generator journal bearings, the thrust bearing, and the turning gear. Additionally, the turbine lube oil system is a backup source of oil supply for the generator hydrogen seal oil system. It also provides oil presiure for the operation of the mechanical overspeed trip and manual trip mechanism.

The turbine lube oil system consists of the following major components:

- Lube oil reservoir

- Turbine shaft-driven main oil pump

- Oil ejector

- Twin oil coolers

- Auxiliary motor-driven oil pumps

- Guarded oil piping

- Loop seal tank

- Unguarded generator oil piping

- Instrumentation and protective devices.

The turbine lube oil system is a closed-loop system using oil that is cooled and pumped to various points of use. The system uses both shaft-driven and motor-driven pumps. The shaft-driven rump in the turbine governor pedestal, together with an oil ejector in the reservoir, pump the oil when the turbine is operating at a near rated speed. Motor-driven pumps are used when the main shaft-driven oil pump and oil ejector cannot supply sufficient oil pressure. The system uses two shell-and-lube oil coolers to regulate the lube oil temperature. The turbine lube oil system contains monitoring and control devices to ensure safe and reliable turbine-generator operation. 


\section{1 .2 .3 Generator Seal O11 System}

The function of the generator seal oil system is to provide sealing of the generator rotor to prevent leakage of hydrogen coolant from the generator.

The generator hydrogen seals are located at the casing shaft penetrations at each end of the generator rotor. Seal oil is continuously injected to the center section of the shaft seals and flows longitudinally in both directions, both toward the generator and away from the generator, sealing the shaft to prevent hydrogen leakage. The oil is collected on both sides of the seal and drains by gravity to the skid-mounted seal oil unit. The oil drained from the generator side of the seal flows through a loop seal trap to the hydrogen side drain regulator, both of which serve to prevent hydrogen from escaping with the seal oil drain flow. From the hydrogen side drain regulator, the seal oil drain flow joins the outboard seal oil drain flow from the generator hydrogen seals and drain overflow from the turbine lube oil. system generator bearing loop seal. The combined seal oil flow is routed to the seal oil vacuum tank from which any vapors are removed via the seal oil vacuum pump. From the seal oil vacuum tank, the seal oil is pumped through a cooler and filter back to the generator hydrogen seals. The turbine lube oil system serves as a backup source of oil. supply for the generator seal oil system.

The skid-mounted seal oil unit consists of the following major components:

- One main seal oil pump with totally enclosed A-C motor

- One backup seal oil pump with totally enclosed D-C motor and starter

- One vacuum pump with totally enclosed A-C motor and oil separator tank

- Instrumentation and protective devices

- Piping and valving

- Gauge panel and junction box. 


\subsection{Electrical Equipment}

The plant electrical systems include the generator and main power transformers, the auxiliary power, and the uninterruptible and DC power supply systems.

The generator and main power transformer system contains the generator, the main power transformer, and power bus. This system includes the excitation system, protective relaying, generator neutral grounding, surge protection, and voltage transformers for each of the three existing units and the new Unit 4. The auxiliary power system consists of the medium-voltage and low-voltage systems for both the existing plant and the new Unit 4 facilities. The uninterruptible and DC power supply system includes the rotary uninterruptible power supply (RUPS) and 125volt DC distribution system.

\subsubsection{Generator and Main Power Transformer System}

The generator and main power transformer system includes the electrical generators, the main step-up power transformers, and power buses; also included are the excitation systems, protective relaying, generator grounding, surge protection, and voltage transformers. The mechanical portions of the generators are included in the turbine-generation system. The system consists of older components for Units 1-3 and new components for Unit 4.

\subsubsection{Existing Unit 1-3 Generator and Step-up Transformer Systems}

The system consists of three identical 13,500-kVA generators and step-up power transformers. The transmission system is $115 \mathrm{kV}$ and the generator voltages are $13.8 \mathrm{kV}$. The generators are connected to the main power transformers by 750-MCM cable. The generator excitation syatems are shaft-driven DC, alternator designs. Generator power factors are 0.85 .

\section{2 .1 .2 New Unit 4 Generator and Step-Up Power Transformer System}

The system consists of one 88,200-kVA generator and stepup power transformer. The transmission system is $115 \mathrm{kV}$ and the generator voltage is $13.8 \mathrm{kV}$. The generator is connected to the main power transformer by the isolated phase bus. A tap from the isolated phase bus connects three surge arresters and two sets of three voltage 
transformers. The neutral end of the generator is connected to a dry-type distribution grounding transformer with a secondary resistor.

The following relay protection is provided (type in parentheses):

- Generator differential (SA-1)

- Generator transformer differential. (HU)

- Generator transformer system ground (neutral voltage, IVA, CV)

- Generator transformer system ground (broken delta voltage, IVA, CV)

- Loss of excitation (long and short reach, CEH52)

- Anti-motoring (GGP)

- Generator volts/hertz (2 stages, STV)

- Transformer volts/hertz (2 stages, STV)

- Under-frequency (2 stages, SDF)

- Out-of-step (CEX/GSY, SDBU)

- Main power transformer neutral overcurrent (IFC,CO)

- Generator system backup (CEB, KD-11)

- Negative sequence (SGC, RAR10)

- Main power transformer sudden pressure.

The excitation system is a manufacturer's standard static excitation system and interface, with accessories and characteristics required by the application. Generator voltage is the manufacturer's standard voltage, $13.8 \mathrm{kV}$.

The gene:-ator kVA rating, at rated power factor, is such that the generator is capable of matching maximum possible turbine output. The generator power factor is 0.9 .

Ampacity of the isolated phase bus is a manufacturer's standard rating, but not less than generator current rating at $95 \%$ of rated voltage. 
Excitation systam speed of response is as required by transmission system characteristics. High initial responos and power system stabilizers may be provided, if required by power system characteristics.

The main power transformer primary (LV) voltage rating is based on the ratio required to permit operation of the generator at rated voltage, kVA, and power factors. These parameters are set with the transmission systom operating at rated transformer secondary voltage.

The main power transformer, secondary (HV) nominal (center tap) voltage rating is approximately the transmission system mean operating voltage.

The main power transformer, secondary (HV) surge arresters and basic impulse insulation level (BIL) are based on transmission system requirements.

The main step-up transformer $\mathrm{kVA} / 65^{\circ} \mathrm{C}$ rise rating is based on the turbine-generator delivering maximum output when the boiler and entire plant auxiliaries are supplied by the auxiliary transformer.

\subsection{Auxiliary Power System}

The auxiliary power system consists of the medium-voltage and low-voltage systems. The medium-voltage system includes a new auxiliary transformer, switchgear, interconnections, and feeders for the entire plant. The low-voltage system includes load centers, motor control centers, intercunnections, and feeders. The auxiliary power system design was based on an estimated total plant auxiliary transformer load of 14,000 kVA when firing the "B" coal. with $100 \%$ extraction on the Unit 4 turbine. Estimated auxiliary power loads were somewhat conservative because of the lack of firm design information at the time. In addition, extra capacity was allowed for possible design changes and/or future equipment additions due to the project's demonstration nature.

Because of space limitations in the switchyard, Colorado-ute elected to eliminate an existing startup transformer, which would allow room for the new station auxiliary transformer. Three existing PCB-filled load center transformers located within the plant were also replaced with two dry-type transformers to eliminate a possible environmental hazard. These transformers are supplied with power from the new station auxiliary transformer. All auxiliary power loads for the Nucla station are furnished by the new station auxiliary transformer. 
The plant medium-voltage system is 4160 volts supplied from the station auxiliary transformer fed from the $115-\mathrm{kV}$ system. This system was the most economical one for satisfactory operation consistent with the plant design philosophy.

\subsubsection{Design Load Estimate Summary}

The following summary is based upon preliminary design load lists. It was anticipated that the estimated loads would be higher than actual loads due to diversity in brake horsepower loadings. This was due to the current state-of-the-art and wide differences between various suppliers. The unique configuration and technology of this project made references to historical plant auxiliary load data unreliable.

Two expected operating conditions for the circulating AFBC boiler were examined. These resulted in the estimated auxiliary plant loads summarized in Table 18. Under operation with the "A"-type coal, the combustion and fluidizing air requirements are reflected in the MCR of the ID, PA, and SA fans. The alternate operating condition was the burning of the "B"type coal, which has a lower heating value and higher combustion and fluidizing air requirements. The load requirements of the ID, PM and SA fans are reflected in the test block conditions, plus an additional design margin established by the boiler vendor. The rated power of each fan was based on the firing of coal "E."

In addition to the 20 o continger zy allocated for future load growth, the boiler vendor identified another major contingency $1 \mathrm{vad}$ to be a gas recirculation fan estimated at $1,112 \mathrm{~kW}$ $(1,500 \mathrm{HP})$. This fan, if installed, would be operated only at minimum load conditions, maintaining gas recirculation in the combustion chambers and the cyclone separators. Because of the operating condition, the gas recirculation fan would not add to the maximum expected auxiliary load for the plant. Therefore, it was not included in the contingency factor.

\subsubsection{New Station Auxiliary Transformer}

A 12/16/20 MVA, oil self-cooled/forced-air cooled/forced-air cooled (OA/FA/FA) $65^{\circ} \mathrm{C}$ rise, two-winding transformer was selected because it was the next standard-size larger than 120 of the estimated maximum load imposed by the plant secondary loads. Based on available information at the time for the new circulating AFBC technology, this was the smallest size that could be recommended and still allow reasonable margin for changes and possible future load additions. The cost savings resulting from a smaller auxiliary transformer 
Table 18

TABULATION OF PLANT AUXILIARY LOADS

Auxiliary Load Estimates, MVA

Unit 4 auxiliary load

Units 1-3 auxiliary load

Total operating load

$20 \%$ contingency

Total estimated load growth

Capacity recommended for new plant auxiliary transformer
Coal A

8.7

2.1

10.8

2.2

13.0

$12 / 16 / 20$
Coal B

11.7

2.1

13.8

2. 2

16.6 
(12/16 MVA, OA/FA $65^{\circ} \mathrm{C}$ rise), with provisions for future addition of coolers to reach 20 MVA, was very small (on the order of $\$ 7,000)$.

One other alternative was to install two half-sized transformers rather than one full-sized. This would have increased the cost and probably decreased reliability.

\subsubsection{Medium-Voltage System}

The medium-voltage system is 4160 volts supplied from a main bus and the station auxiliary transformer fed from the $115-\mathrm{kV}$ system. Motors larger than $187 \mathrm{~kW}$ (250 HP) and 480 volt load centers derive their power from this bus.

This voltage is necessary to allow the starting of the large motors. The largest motors for across-the-line starting are on the Unit 4 boiler feed pumps (1307 kW or $1,750 \mathrm{HP}$ each). A $14 \%$-voltage dip has been calculated on the system when one of these motors is started. This drop is within acceptable limits for successful starting and operation.

The use of adjustable speed drives for the large fan drives (ID, PA, and SA fans) eliminated the high starting kVA requirements for these large drives $(2425,2611$, and $522 \mathrm{~kW}$ or, $3,250,3,500$, and $700 \mathrm{HP}$, respectively).

The medium-voltage system is resistance grounded with adequate fault current (1000 amperes) for positive relay operation.

The 4160-volt system is extended to the Unit 4 croling tower area via a single feed. A 500-kVA load center and two 400ampere medium-voltage starters for the circulating water pumps are fed from this source. The primary advantage of this arrangement is that an existing duct bank could be used, thus avoiding a major construction cost for a new duct bank system to the new cooling tower. The disadvantage is that a failure of the $5-\mathrm{kV}$ feeder cable will result in a complete cooling tower outage until the cable is repaired or replaced. An outage would most likely occur as a result of a cable failure even if redundant feeds to the cooling tower were installed.

\section{$5.3 .4 \quad 480-$ Volt System}

The 480-volt system consists of new and existing load centers, motor control centers, lighting and power panels, intarconnectiuns, and feeders. Voltage drops and transformer impedances were calculated in order not to exceed circuit breaker ratings (minimum impedance) and not to exceed $20 \%$ maximum voltage drops on motor starting. The largest motor that can be 
adequately started on the 480-volt system is $149 \mathrm{~kW}$ (200 HP). A voltage drop of approximately $17 \%$ while starting was calculated. This value is marginally acceptable.

\subsubsection{Emergencs: Power}

No backup $480-\mathrm{V}$ power source is provided.

\subsubsection{Harmonic Considerations}

Harmonics generated by the adjustable-speed fan drives were analyzed for effects on the entire station electrical system. This analysis was performed by the adjustable-speed drive system supplier. The analysis was performed for the expected MCR ratings of the fans, as well as under both full load (test block) conditions, and single-channel (six-pulse) backup operation.

The adjustable-speed drives (ID, PA, and SA fans) account for approximately $50 \%$ to $60 \%$ of the total plant auxiliary load requirements and, therefore, harmonics may have a significant impact on the power systern. Frequency effects on power systems have recently been under study due to the growing application of variable-frequency adjustable-speed drives, but these are not yet fully understood.

Harmonic effects on metering, relaying, transformers, motors, and resonant voltages on the power system will be monitored by Colorado-Ute. The variable-frequency drive system supplier planned to furnish all necessary filtering to stay within the 5\% total harmonic distortion limit, as recommended by Institute of Electrical and Electronics Engineers (IEEE) standard 519-1981, for the auxiliary power system.

\subsection{Uninterruptible and DC Power Supply}

The uninterruptible and DC power supply consists of a RUPS and an 125-volt DC distribution subsystem. The RUPS system includes a battery, DC distribution center, chargers, motor-generator set switches, and control and distribution panels. The 125-volt DC distribution system includes a battery, DC distribution center, battery chargers, and 125-volt DC distribution panels. These systems are provided new with Unit 4.

\subsection{Electrical Bulk Materials}

The electrical bulk materials include electrical items not specified with the electrical equipment systems; i.e., those items not included in the generator and main power transformers, auxiliary power, or the uninterruptible and DC power supply systems. The 
plant electrical bulk materials are comprised of existing and new materials. The electrical bulk materials include the following items:

- Cable trays

- Conduits

- Communications

- Cathodic protection

- Grounding (other than for the main generators)

- $\quad$ Lighting

- Underground ducț

- Heat tracing

- Wire and cable.

The plant communications system is an extension of the existing "Gai-Tronics" handset and speaker stations. 
Section VI. Plant Instrumentation and Controls Equipment and Systems

This system includes all plant new and existing instruments and controls, with the exception of a few instruments and controls provided by the $A F B C$ boiler manufacturer which are described in Section II under "Boiler Instrumentation and Controls."

Plant control is accomplished using modern distributed control techniques, which use redundant processors and dual data highways to improve system reliability and availability. operator interface to the plant is from a new central control room utilizing CRT graphic display and keyboard terminals with a minimum number of hardwired, dedicated switches and indicators to ensure safety and reliability.

The basic control mode is automatic with operator ov rride. Safety systems are hardwired to trip. The basic display mode for information is by the broadcast method. This provides the operator with all current information required, and also automatically provides information on abnormal plant conditions.

\subsection{Analog Control}

The analog control system is part of the microprocessor-based system referred to as the plant Distributed Control system (DCS). Operator interface with the DCS is via CRT and keyboard terminals. The CRT displays are segregated to provide logical groupings of plant control by unit number (e.g., 1, 2, or 3), system (e.g., boiler, baghouse), and function (e.g., feedwater control, combustion control). All plant analog control requirements are performed by this system, including, but not limited to combustion, feedwater, ash handling, and baghouse controls. All loops are capable of manual or automatic operation via the main control room CRT/keyboard interface. All transfer operations are automatic balance-type to provide bumpless transfer between automatic and manual mode selection in both directions. Hardwired backup is included as required for tripping of major pieces of equipment only.

\subsection{Digital Control}

The digital control system, which is also part of the DCS, provides sequential, digital interlock logic control of plant equipment such as fans and pumps. Status and alarms from the digital system are displayed on the operator CRTs and recorded on hardcopy printout. 


\subsection{Alarms and Annunciators}

Alarms are annunciated, requiring operator attention. Alarms are displayed on the appropriate operator control CRT and on hardcopy printout, grouped by system. CRT pictorial graphics (e.g., bottom ash cooling) incorporate alarm points. Some local annunciators are provided with a single output to the plant alarm system which indicates any local alarm actuated. The local annunciator also is provided with "reflash" capability so that subsequent local alarms are detected in the main plant control room. The alarm system is designed so that the operator is not overwhelmed by nuisance or unimportant alarms. All alarms are recorded on hard copy for future reference by operators and plant engineering personnel.

\subsection{Pneumatic Controls}

Pneumatic controls are used for single-element closed-loop, local control systems only.

\subsection{Control Mode}

The basic plant control mode for the AFBC boiler/turbine cycle is a boiler-follow mode. This is provided because the boiler is required to produce steam as demanded by the turbine-generators.

\subsection{Control Drives}

The control drives are pneumatically driven based upon the specific needs and sizes of each controlled drive unit. The cuntrol valves are also pneumatically actuated. Modulated control drives and valves are supplied with electric/pneumatic (E/P) positioners.

\section{$6.7 \quad$ Displays}

The DCS gathers and displays information for the operator and for the plant engineer. The basic information display functions are as follows:

- Alarming for the operator.

- Events recording for normal plant events.

- Sequence of events recording and display of plant upsets.

- Scanning of analog and digital inputs.

- Logging of trends called for by the operator. 
- Logging of dally and hourly summarles of averages, totals, etc., of analog inputs within limitations of the DCS.

- Graphic display capabilities upon demand by the operator within limitations of the DCS.

\subsection{Local Control Systems}

The preboiler water treatment system is controlled locally (outside the main control room) by programmable controllers.

\subsection{System Design Responsibilities}

The following systems are integrated with the DCS and are controlled by the main plant operator. Their control philosophy and logic was developed by the equipment supplier. These systems include:

- Boiler controls

- Burner management system

- Main interlocks and purge system

- Ash handling

- Baghouse.

\subsection{AFBC Boiler Furnace Safety and Fuel Automation System}

The field-mounted circulating AFBC boiler furnace safety and fuel automation system hardware was purchased with the boiler to ensure that the ignition system and damper drives were correctly interfaced with the boiler equipment. The AFBC boiler supplier was responsible for control philosophy and logic.

Where possible, the furnace safety and fuel automation system was designed in accordance with National Fire Protection Association (NFPA) standards. However, due to the new circulating AFBC combustion technology being demonstrated, NFPA standards are not directly applicable.

The basic control mode is "supervisory manual" (operator initiation of start/stop of major equipment items). Redundant instrumentation is employed where necessary (two of three, trip logic, etc.) to minimize nuisance trips. 


\subsection{Control Panel/Cabinets}

The CRT/keyboard control consoles were purchased with the main control system. One hardwired panel (Auxiliary Control Console $4 A)$ was purchased separately. The four CRT/keyboard panels, the Auxiliary Control Console $4 \mathrm{~A}$ (for the existing Unit 1-3 turbinegenerators, and the Unit 4 turbine-generator trip panel insert) are provided in the new plant control room. One CRT/keyboard engineer's console is provided in the new logic room. Preassembled cables with plug-in module ends on each cable were employed. The distributed control equipment is located in a new remote logic room, which contains all the input/output and control cabinets for field devices except the baghouses, part of the ash system, and Units 1-3. The main logic room is located beneath the new control room. The protective relay, turbinegenerator, and coal and limestone feeder cabinets are located in the logic room.

\subsection{New Turbine Control System}

The new turbine control system was purchased as part of the new Unit 4 turbine-generator. This system can be started manually from the main control room.

\subsection{Emission Monitoring System}

The stack-monitoring system consists of instrumentation for monitoring and reporting the sulfur dioxide $\left(\mathrm{SO}_{2}\right)$, nitrogen oxides $\left(\mathrm{NO}_{x}\right)$, carbon dioxide $\left(\mathrm{CO}_{2}\right)$, and the opacity of stack emissions as required by the Federal Environmental Protection Agency (EPA) and state and local pollution-control authorities.

Stack emissions monitoring instrumentation is located in the ductwork between the ID fan discharge and the stack inlet. The instruments use in-situ ard extractive measurement techniques. The stack monitoring equipment is located in a building next to this duct. Analog signals from the instruments are wired to the DCS to allow the operator to monitor stack emissions and take corrective action when required.

The stack emissions monitor is a software package designed in accordance with the requirements of the Clean Air Act for new stationary sources. The combined product achieves the following functions:

- The scanning, conversion, and linearization of measured emissions concentrations.

- The computation of pollutant emissions using the methods specified by the Clean Air Act. 
- Reduction of emission data as required under the Clean Air Act for data which are to be retained.

- Hourly determination of periods of excess emissions of $\mathrm{SO}_{2}$ and $\mathrm{NO}_{x}$ using required calculations.

- Determination and logging of excess opacity emissions.

- Hourly recording of events; i.e., generation unit was in startup or shutdown, emissions analyzer was out of service for the current hour, excess emissions were determined, computer was initialized, etc.

- Data logging: The stack emissions monitor produces two different reports, a daily emissions $\log$ and a monthly excess emissions report. The daily emissions log contains all data available which should be retained as specified by the clean Air Act. The monthly emissions report is a summary of all periods of excess emissions as determined on an hourly basis and is intended to be attached to the quarterly emissions report.

- Analyzer interface: The stack emissions monitor provides a simple interface (contact input) to allow off-line calibration and standardization. 
Section VII. Special Instrumentation

The special instrumentation are includes instrumentation, data acquisition and processing equipment, and facilities installed speciflcally for EPRI's two-year AFBC test program. Special instrumentation equipment and facilities data is included in Appendix A.

\subsection{Data Acquisition System Computer and Peripherals}

This equipment provides for acquiring, monitoring, and broadcasting plant process data from the plant data highway system. The data highway is part of the plant Westinghouse WDPF distributed control system.

\section{1 .1 Operator's Console (OPCON)}

The Operator's Console (OPCON) which includes a CRT and a membrane keyboard is a direct interface to the WDPF system. Using the CRT and the membrane keyboard, plant systems can be monitored via standard and custom display graphics, which show the status of equipment and the state of processes throughout the pla.t. The graphics are linked in a hierarchical manner to reflect the flow of the process. Paging keys on the OPCON keyboard allow movement to the next graphic in any of four directions. Graphics may also be selected from custom keys which have been assigned specific process graphics. Selection of the "DISP MENU" key will display an overview of the graphic hierarchy.

A multicolor printer provides a means to obtain hard copies of any CRT display. All plant control functions are locked out of this console; this unit is remotely located from the main plant control room.

\section{1 .2 DES VAX 8200 Computer}

The DEC VAX 8200 computer provides the hardware and software for monitoring and capturing process points from the WDPF data highway. Point data as well as other manual input test data are stored in a database to provide real time or historical data as required for analysis of plant performance. The computer can receive data unly from the system and therefore cannot perform any control functions in the plant.

\section{$7.1 .3^{\prime} \quad \underline{D P U 11}$}

DPU11 is a WDPF Distributed Processing Unit (DPU) which is used to monitor additional process data points that were not available as part of normal monitoring and control of the 
plant process systems. It serves as the interface between these process points and the data highway and consists of dual redundant microprocessors and input/output (I/O) modules. The I/O modules interface with the process sensing instruments. Each process input is defined in a local resident database which, in turn, is part of the distributed global database. Microprocessor functions and routines scan and convert input signals to required ranges and engineering units. The DPU then broadcasts these points on the data hir rway, making them avallable for capture by the DEC VAX 8200 conputer.

\subsubsection{Gateway}

The Gateway interfaces the DEC VAX 8200 computer to the WDPF system enabling it to access data highway points.

\subsection{Special EPRI Test Program Instruments}

Equipment furnished consists of special or additional instruments and test ports required by EPRI for plant testing, which are not found among the main plant control and monitoring instruments. Additional access platforms and ladders for EPRI instrumentation, test weights for coal feeder and ash hopper calibrations, and the addition of 37 duct pressure tapes for flow measurement verification of associated duct flow elements are also included.

All transmitters and thermocouples that require a power source or electronic signal conditioning terminate in DPU11, which conditicns signals as required. The conditioned signal is then available on the data highway for use by EPRI in the DEC VAX 8200 computer.

Special test ports/taps installed include:

- Duct pressure taps consisting of two-inch threaded nipples with reduced-port ball-valves, which were added to various combustion air ducts to allow grid pattern pitot traversas of the ducts. The traverse data will be used to verify readings on air foils being used for plant monitoring and control.

- Eifteen protractor/air lock assemblies, furnished for use with the duct pressure taps to allow insertion and orientation of the traverse probe.

- Ash sample points, installed on the economizer and air heater ash hoppers to allow collection of ash for testing. These sample points consist of full flow two-inch ball valves and pipe nipples. Samples are collected using thief sample tubes. 


\subsection{Eacilities and Equipment to Support EPRI Test Program}

Equipment and facilities are provided for the:

- Operations Center and Computer Rooms including installation of data acquisition equipment and a RUPS for the equipment.

- Chemical lab facilities and procurement of miscellaneous lab equipment.

\subsubsection{Operations Center and Computer Rooms}

The Operations Center and Computer Rooms were built as temporary facilities inside the future Colorado-Ute operations warehouse. These facilities consist of two air-conditioned rooms, which house the DEC VAX 8200 computer and the Westinghouse WDPF OPCON with their accessories. In addition to air conditioning, the rooms are equipped with a positive pressurization fan to protect against dust accumulation.

The first room, the Computer Room, houses the DEC VAX 8200 computer along with the 456-megabyte fixed disk, the 80megabyte tape drive, and the WDPF Gateway equipment.

An adjacent room, the Test Operations and Data Analysis Room, houses the WDPF OPCON and associated printer, as well as, the DEC VAX 8200 system peripheral devices which include the video terminals, printers, and plotter.

The electronic equipment supplied by DEC and Westinghouse requires a stable and reliable source of 115-VAC power which is buffered from transient line voltage fluctuations and plant blackout conditions. This is provided by taking a power feed from the plant RUPS system. This RUPS equipment uses a rotary-type of motor-generator set which in normal operation is driven by house power. When house power fails, the generator is driven by a DC notor which is connected to a battery bank. The battery bank is sized for one hour of operation following house power failure; this will allow time for orderly shutdown of equipment. UPS 110 VAC receptacles provided for the electronic equipment must not be used to power any loads except those shown on the appropriate panel schedule. This will prevent unauthorized power loads from overloading the system or causing system failure by fault conditions.

Both rooms are monitored by a fire detection system. This system provides an alarm through the WNPF system to the main plant control room operator in the event of fire. It is 
important to note that no automatic fire-extinguishing equipment is furnished, and in the event of an alarm, an inspection must be made by a qualified observer to determine the cause of the alarm and to take the appropriate action.

An additional alarm, also through the WDPF system to the main plant control room operator, is provided in the Computer Room should the air conditioning fail and the room temperature reach $20^{\circ} \mathrm{C}\left(85^{\circ} \mathrm{F}\right)$, or if trouble in the fire alarm panel is detected. In the event of an alarm, the cause should be immediately investigated. If the alarm is due to room temperature at $29^{\circ} \mathrm{C}$, the computer should be turned off until the problem is corrected.

\subsubsection{Chemical Laboratory Facilities and Equipment}

Three rooms are provided for sample preparation and sample analysis: the Sample Preparation Room, the Particulate Laboratory, and the Analysis Room. These rooms also were built as temporary facilities inside the future Colorado-Ute operations warehouse.

The Sample Preparation Room is designed to prepare all samples for chemical analysis. This may include coal surface moisture, limestone moisture, size distributions of coal, limestone, fly ash and bed material, and bulk densities of fly ash and bed material.

The Particulate Laboratory will be used to prepare isokinetic sample equipment and other specialty probes. The Analysis Room will be used for sulfur analysis of prepared samples. The Sample Preparation Room and the Particulate Laboratory are equipped with exhaust hoods for control of particulate emissions. Only the Particulate Laboratory is equipped with running water, a sink, and a drain. Since no chemical disposal is anticipated, the drain system has not been designed to accep chemical waste.

\subsection{Ash Weighing System}

The furnished ash weighing equipment provides for:

- Fly ash and bottom ash weighing

- Sampling devices for the following solid streams:

-- "As fired" coal feed

- Limestone feed 
-- Baghouse catch.

\subsubsection{Fly Ash Weighing}

The fly ash-weighing system consists of a surge bin and a Schenck solids flow metering system located between the cyclone discharges and the fly ash silo. The Schenck metering system provides an analog output of flow rate and a digital pi se output where one pulse is equiralent to 0.01 tons. Digıtal alarm signals for system trouble/surge bin high level/valve misalignment are also provided. These signals are all inputs to the WDPE system. Bypasses are provided around the Schenck meter for normal operation.

The WDPE system provides operator interface for remote control of this system. A process and instrumentation diagram (P\&ID) control graphic, titled FLY ASH WEIGHING, can be accessed by paging down from either the Unit 4 Fly Ash or the Units 1,2,3 Fly Ash Graphics. Tiue system is semiautomatic. Control is a combination of local hard-wired and WDiF logic. A start of the system can be initiated either locally at the silo oi remotely from a WDPF Operator's console.

At the start of a test period, a start command (local or remote) will divert fly ash flow from bypass to the Schenck metering system. At this command, the totalized flow indication is reset to zero. Both the flow rate and the totalized flow will be displayed on the graphic and also be available on the data highway. WDPF provides conve:sion of the 0.01 ton pulse to an analog value in engineering units of thousands of pounds $(\mathrm{klb})$. At the end of a test period, the operator will divert fly ash flow from the weigh system back to bypass with a stop command. At this point, the bypass gates are opened and the feeder gate to the Schenck meter is closed. The rotary valve will continue to run for five minutes to purge the flow meter. At approximately one minute after the rocary valve stops and the weigh system has been shut down, the WDPF will provide a digital trigger signaling that the value of the totalized flow should be read into the VAX computer. In addition, WDPE logic will provide the ability to manually reset the totalizer at any time including the periot that fly ash flow is through the weighing system. This manul reset can only be done with a control room Operator's console in the unlocked mode.

A high level in the surge/weigh bin will automatically bypass the weighing system. 


\subsubsection{Bottom Ash Weighing}

Bottom ash weighing is accomplished with a load cell system on each of the bottom ash hoppers. Inputs to the WDPF are for Bottom Ash Hopper 4A weight and for Bottom Ash Hopper 4B weight. During a test period, the WDPF will provide digital trigger signals for each of the hoppers at their high and lowlevel points. There are two modes of ash operation to consider:

A. Normal operation with ash temperature less than $191^{\circ} \mathrm{C}$ $\left(375^{\circ} \mathrm{F}\right)$

The operator selects (via the OPCON keyboard)

(1) Hopper 4A "ON" or "BYP"

(2) Hopper 4B "ON" or "BYP"

(3) Bottom Ash Rotary Valves "ON".

The operator then initiates a system start. With the conveying line valve to Hopper $4 \mathrm{~B}$ normally open and the conveying line valve to Hopper $4 \mathrm{~A}$ normally closed: the selected exhauster, bag filter, and separator are started. When conveying air vacuum is adequate, conveying the line $4 \mathrm{~B}$ is puiged for 10 seconds and then the Bottom Ash Hopper $4 \mathrm{~B}$ out let valve is opened. Ash is then conveyed from Hopper $4 \mathrm{~B}$ for a period of 90 seconds. If high load vacuum is sensed, ash conveying can be interrupted during the 90 seconds by closing the hopper outlet valve. Upon return to normal vacuum, the hopper outlet valve will reopen and conveying will continue for the remainder of the 90second cycle. At the end of 90 seconds, the hopper outlet valve will close and the conveying line to Hopper $4 \mathrm{~B}$ is purged for 30 seconds before conveying line valve $4 \mathrm{~B}$ is closed and snveying line valve $4 \mathrm{~A}$ is opened. Conveying line $4 \mathrm{~A}$ is : urged for 10 seconds and then Bottom Ash Hopper $4 \mathrm{~A}$ outlet valve will open. Ash is conveyed from Hopper $4 \mathrm{~A}$ in a like manner as described for Hopper 4B. At the end of Hopper $4 A^{\prime} s 90$-second cycle, the system sequences back to Hopper $4 \mathrm{~B}$ and cycles through this 130-second purge/conveying/purge cycle until stopped by the operator.

B. Normal uperation with ash temperature more than or equal to $191^{\circ} \mathrm{C}\left(375^{\circ} \mathrm{F}\right)$.

Should ash temperature reach more than $191^{\circ} \mathrm{C}\left(375^{\circ} \mathrm{F}\right)$, ash conveying wlli be interrupted and an aiarm wiil sounc fur the operator to start Screw Cooler $4 \mathrm{~A}$ or $4 \mathrm{~B}$. As an 
example, assume the conveying cycle was at Hopper $4 \mathrm{~A}$ and $191^{\circ} \mathrm{C}$ ash is detected. At that point, ash conveying is stopped by closing Hopper $4 \mathrm{~A}$ outlet valve, and the alarm "START SCREW COOLER 4A" is activated. The cycle timers continue to run and may even time out and switch to Hopper $4 \mathrm{~B}$ before the operator can start Screw Cooler 4A. Ash conveying would then commence from Hopper $4 \mathrm{~B}$ in a normal fashion, provided the temperature transmitter does not also detect $191^{\circ} \mathrm{C}$ ash temperature. In the meantime, the operator has started Screw Cooler $4 \mathrm{~A}$. it is proven $\mathrm{ON}$ in the control logic and the inlet valve to the screw cooier is opened. When the cycle again returns to Hopper 4A, there is the normal 10-second line purge; however, the sarew cooler's outlet valve is opened instead of the hopper outlet valve. Now the ash conveying is taken from Hopper $4 \mathrm{~A}$ via the screw cooler. The sequence timers function as previously described. When Screw cooler $4 \mathrm{~A}$ was started, a three-hour timer was also started. At the end of three hours, and if the ash temperature has returned to below $177^{\circ} \mathrm{C}\left(350^{\circ} \mathrm{F}\right)$, the inlet to screw cooler $4 \mathrm{~A}$ will be closed and the screw cooler will be purged for 30 seconds before it is stopped. Bottom ash conveying logic will then return to conveying directly from the lopper.

Ash weighing is accomplished when the WDPF will provide one HIGH and one LOW hopper level digital trigger signal for each bottom ash hopper. These signals will indicate when to read the values. The low-level trigger will have two level set points depending on screw cooler on/OFF status. One set point will be at $10 \%$ of range with the screw cooler off, and the other will be at $20 \%$ of range with the screw cooler on. The high-level trigger will be set at $90 \%$ of range. Deadbands for all settings are $1 \frac{\circ}{6}$ of range. Understand that actual bottom ash flow rates may require adjustments to sequence timers, trigger set points, and deadbands in order to establish a functional weighing system.

\subsubsection{Coal "As Fired" Sampling*}

The "As Fired" coal sampling is a manual function. Each of the six coal feeders has a pneumatically operated diverter

Note: The "As Fired" coal sampling equipment installed for the EPRI test program, as described above, is independent and separate from the plant "As Received" and "As Fired" coal sampling equipment -ncluded with the plant coal handing system. 
gate located at the outlet end of the feeder. The gate is operated by energizing a solenoid valve from a local push button station also located near the end of the feeder. The gate will divert approximately a 12.7 liter $(0.45 \mathrm{cu} f t)$ cut of coal flow to a sample outlet. From this point the coal sample passes through a transition section to a $10-\mathrm{cm}$ (4-in) pipe with a lever-operated knifegate valve at the outlet. The sample is then manually dumped into a container for transport to the sample laboratory.

\subsubsection{Limestone Sampling}

Limestone sampling is also a manual function. Each of the eight limestone transport lines (four on each combustor) contains a two-inch capped sample tap located just above the rotary valve. "Thief" sample devices are used to manually extract samples from these points.

\subsubsection{Ash Transport Sampling}

Ash sampling is also a manual function. Sample points are located at the top of each of the bottom ash hoppers and in the fly ash weigh bin located at the top of the fly ash silo. "Thief" sample devices are also used to manually extract samples from these points.

\subsection{Gas Analyzers}

This equipment allows data collection on gases in Combustion Chamber $4 \mathrm{~B}$ and at the inlet to Tubular Air Heater $4 \mathrm{~A}$. Future connections are available at the inlet and outlet of Cyclone 4B. Samples taken at Tubular Air Heater 4A are called EGAS samples and samples from Combustion Chamber $4 \mathrm{~B}$ are called FGAS samples. The method of sampling is extractive, with all samples being analyzed in the E/FGAS Analyzer. The system has been designed to sample and monitor concentrations of $\mathrm{CO}_{2}, \mathrm{CO}, \mathrm{NO}_{x}$, and $\mathrm{SO}_{2}$. Expansion space is available to add future analyzers.

\section{$7.5 .1 \quad$ E/FGAS Analyzer}

The E/FGAS Analyzer is a gas analysis and monitoring system designed to continuously monitor sample gas concentrations from selected sources. The sample point and measuring range are manually chosen by the system operator. Sample points which can be chosen are as follows:

$$
\begin{aligned}
& \text { 1. FGAS at elevation } 13.6 \mathrm{~m}(44 \mathrm{ft}-7 \mathrm{in}) \\
& \text { 2. FGAS at elevation } 26.4 \mathrm{~m} \text { (86 ft-6 in) }
\end{aligned}
$$




\section{EGAS at the inlet to Tubular Air Heater $4 \mathrm{~A}$ \\ 4. Future (Cyclone $4 \mathrm{~B}$ inlet or outlet).}

The FGAS samples are taken via traversing probes, described in more detail below, which are inserted into Combustion Chamber $4 \mathrm{~B}$ at either boiler elevation $13.6 \mathrm{~m}(44 \mathrm{ft}-6 \mathrm{in})$ or $26.4 \mathrm{~m}$ (86 ft-6 in).

EGAS sample is an average of 16 sample points. Samples are drawn by a heated valve enclosure which is located midway between the two inlet ducts to Tubular Air Heater $4 \mathrm{~A}$ at an elevation of $28.7 \mathrm{~m}(94 \mathrm{ft})$. Each of the two inlet ducts has a $2 \times 4$ grid of eight sample points which terminate in the heated valve enclosure. These 16 sample points are averaged in the enclosure and sent as one sample to the E/FGAS

Analyzer. The averaging enclosure is heated to prevent sample gas temperature from falling below the acid dew point.

Each of the 16 sample points also has an associated thermocouple. The eight thermocouples in each duct are averaged locally in a thermocouple averaging terminal box. The resulting two averaged temperatures are sent to DPU11 and are available separately on the data highway.

At the outlet of Tubular Air Heater 4A, two thermocouple grids have been located. These grids are identical in layout and connection to the thermocouple grids at the inlet. The resulting two averaged temperatures are also available on the data highway.

Calibration of the E/FGAS Analyzer is accomplished by drawing known concentrations of sample gas through the system at regular intervals. These calibration or span gases are located in cylinders adjacent to the E/FG $1 S$ Analyzer as fol lows:

\begin{tabular}{|c|c|}
\hline Bottle & Gas \\
\hline 1 & $\mathrm{~N}_{2}$ for zero reference \\
\hline 2 & Low span $\mathrm{O}_{2}, \mathrm{CO}, \mathrm{CO}_{2}$ \\
\hline 3 & $\mathrm{High}$ span $\mathrm{O}_{2}, \mathrm{CO}, \mathrm{CO}_{2}$ \\
\hline 4 & Low span $\mathrm{SO}_{2}, \mathrm{NO}_{x}$ \\
\hline 5 & $\mathrm{High}$ span $\mathrm{SO}_{2}, \mathrm{NO}_{x}$ \\
\hline
\end{tabular}

The E/FGAS Analyzer equipment is located at an elevation of $7.3 \mathrm{~m}(24 \mathrm{ft})$ on the turbine deck. This includes a gasconditioning cabinet and an air-conditioned cabinet which contains the gas analyzers, a six-pen chart recorder, and other system components. An output signal from each analyzer, 
corresponding to the gas concentration at the analyzer, is sent to DPU11. These signals are available on the data highway. In addition, the chart recorder displays the outputs of the analyzers. Other signals are available for system alarms and range settings of the various analyzers. The output signals are summarized below.

- $\mathrm{O}_{2}$ is masured using a Beckman Industrial Corporation Moces 7755/ which is a paramagnetic type of analyzer.

- $\quad \mathrm{CO}$ and $\mathrm{CO}_{2}$ are measured with Beckman Industrial Corporation Model 864 analyzers which operit ising the principle of infrared absorption.

- $\mathrm{NO}_{\mathrm{x}}$ is measured with a Beckman Industrial Corporation Model 951A analyzer which operates on the principle of chemiluminescence.

- $\mathrm{SO}_{2}$ is measured with a Western Research Model $721 \mathrm{~A}$ sulfur dioxide analyzer which operates on the principle of energy absorption by a sample cell.

The E/FGAS Analyzer equipment was furnished by KVB Corporation. Further descriptions and detailed specifications are found in the KVB System Manual furnished with the equipment.

\subsubsection{FGAS Probes}

The Freeboard Gas (FGAS) Sampling Probe is designed to allow sampling of gases from inside the operating fluid bed boiler. The probe is a water-cooled design originally developed by TVA and EPRI for use in the analysis of a bubbling bed combustor. The current probe design has been modified to incorporate site specific characteristics of the Nucla circulating AFBC boiler.

The probe is designed to sample gases over a traverse distance of $3.1 \mathrm{~m}$ (10 ft-2 in) inside the operating combustion chamber. The probe is essentially a water-cooled, electrically heated tube, which is connected to the E/FGAS Analyzer via a heated sample line. Suction, provided by a vacuum pump at the conditioning cabinet, pulls gases from the combustion chamber into the gas analyzer system for analysis.

In operation, the combustion gases first pass through a quench tube where the gas temperature is reduced to less than the $204^{\circ} \mathrm{C}\left(400^{\circ} \mathrm{F}\right)$ (maximum operating temperature of the sample line). This electrically heated sample line then maintains the gas temperature above the acid dew point of the sample gas [set point of $177^{\circ} \mathrm{C}\left(350^{\circ} \mathrm{F}\right)$ ] to minimize acid condensation and the resulting corrosion. Gases are sampled at a flow rate of 
approximately seven liters per minute. After exiting the sample line, the gases pass through a cyclone separator to remove any entrained solids. The sample gases are then transferred via another heated sample line to the E/FGAS analyzer for chemical characterization.

The probe itself is water cooled to protect the sample line and to maintain the structural integrity of the probe. A water flow rate of between 23 and 91 liters/min ( 5 and $20 \mathrm{gpm}$ ) is required to maintain internal temperatures below $157^{\circ} \mathrm{C}$ $\left(175^{\circ} \mathrm{F}\right)$. Seven thermocouples are included in the system to allow the sampling team to monitor the operating conditions inside the probe. Cooling water passes through the length of the probe and returns to the outlet nozzle before being discarded in the plant drain system. Water flow control is maintained by a manual control valve on the cooling water inlet line.

The probe includes some optional sampling equipment. An entrainment cap is supplied to serve as both protection for the 3/8-in sample line and to reduce the entrainment of solids. A filter clamp is also provided to hold a hightemperature ceramic filter over the end of the sample line. These ceramic filters are designed to remove all particulate matter larger than 85 microns in diameter while sampling gases up to $1371^{\circ} \mathrm{C}\left(2500^{\circ} \mathrm{F}\right)$.

Previous experience by EPRI and TVA has indicated that the ceramic filters tend to change the composition of the gas sample as they become plugged. The quantity of ash in this unit, however, may dictate use of these filters or others. 
NUCLA CEB DEMONSTRATION PROJECT

APPENDIX A

PROJECT EQUIPMENT AND DATA LIST 
品

$y$

ब্র

गै
0
0
है
व⿱
0

E
.-1
+1
0
$?$
है
0
0

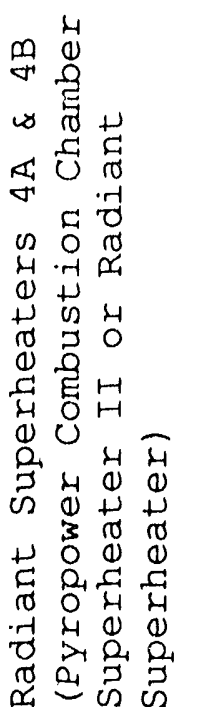

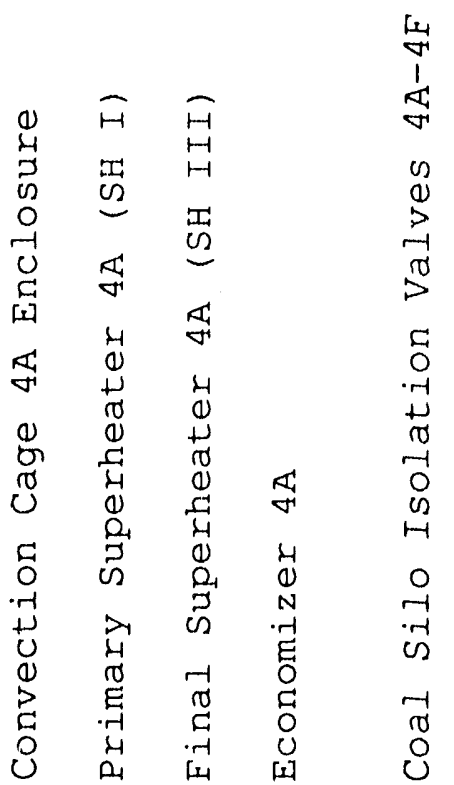




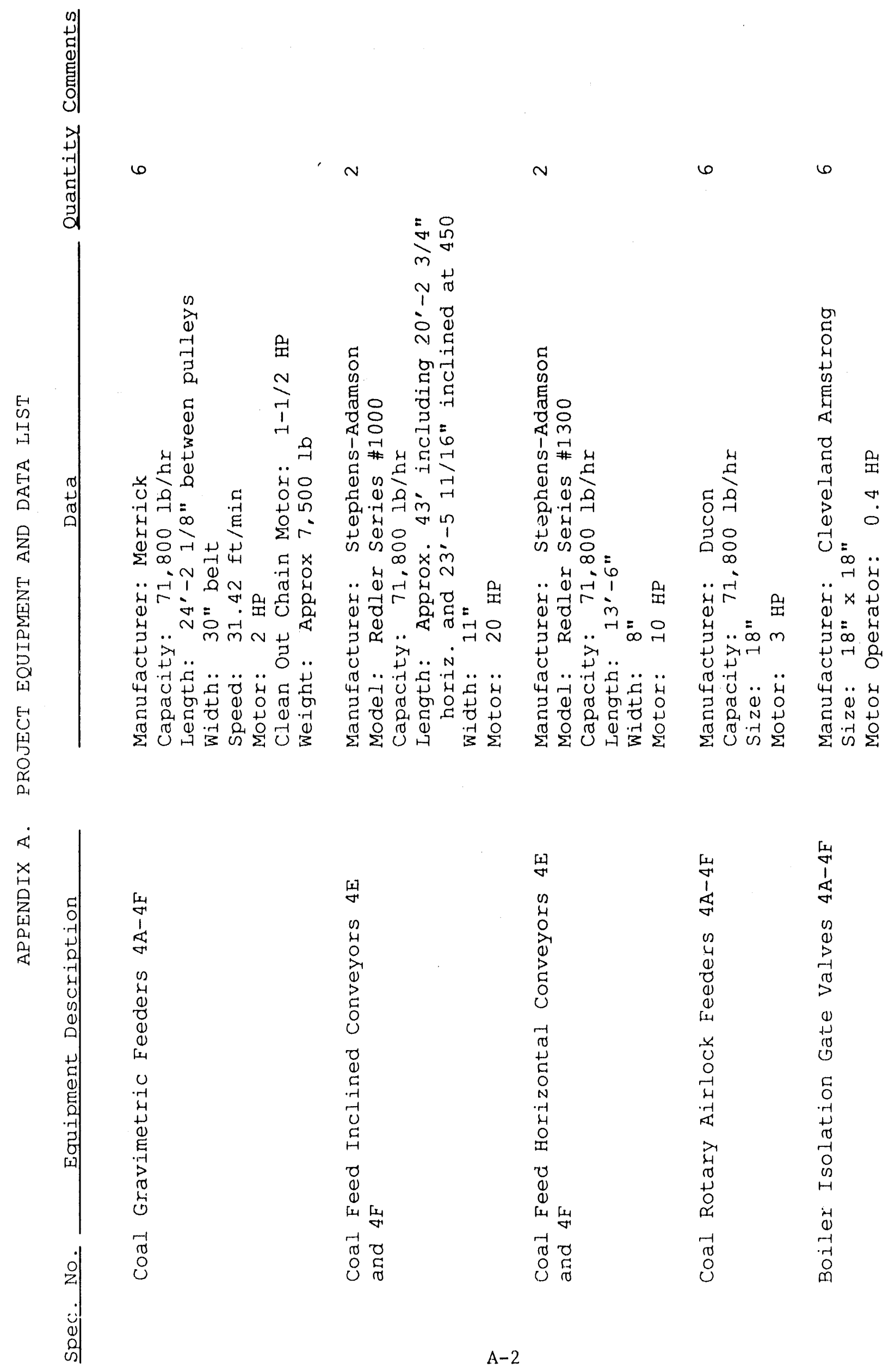


$\infty$

$\infty \quad \infty$

年

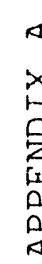

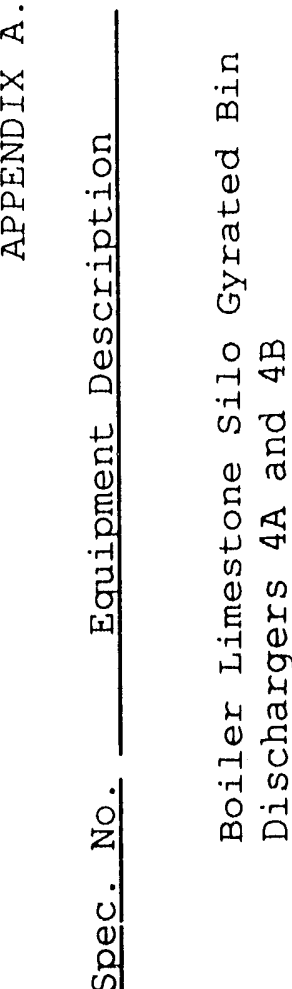

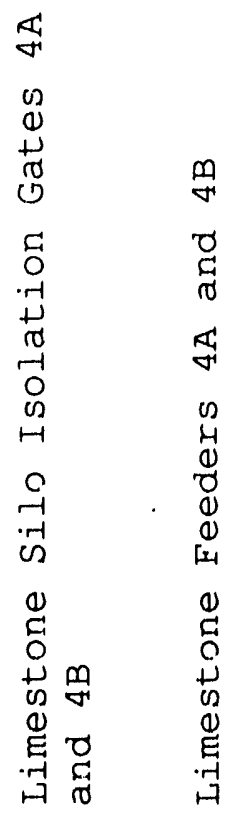

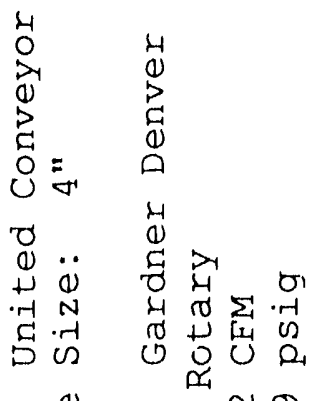

ठठ

. (1)

4

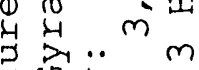

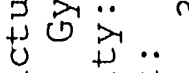

(0) बi $0,6 \cdot+1$

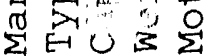

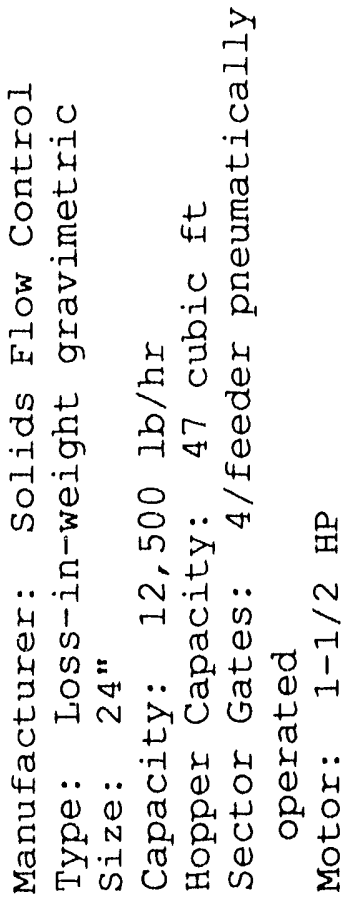

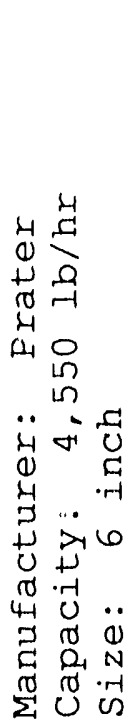

..

藏. मे

म 4 م

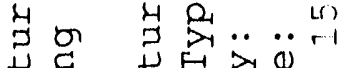

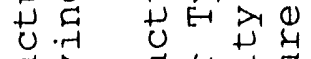

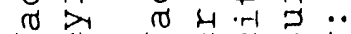

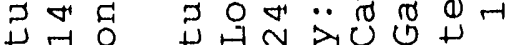
0 U 0 म 证...

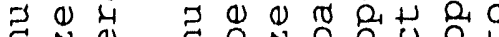

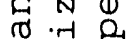

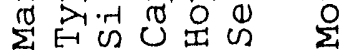

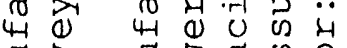

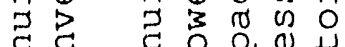

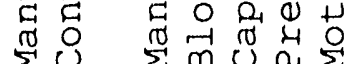

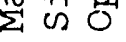

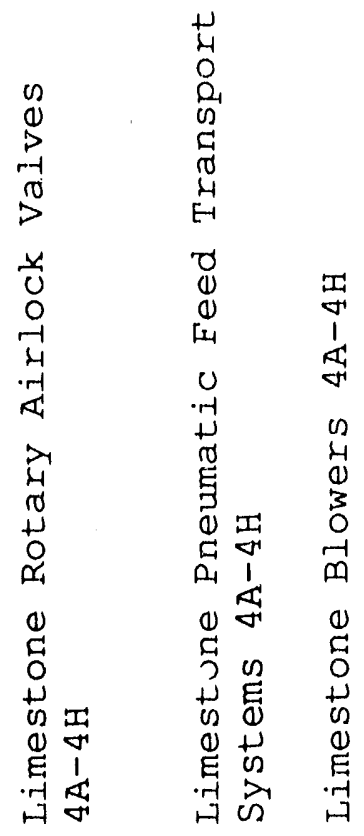




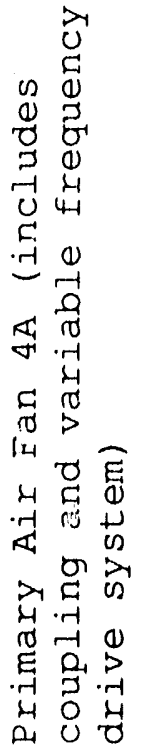




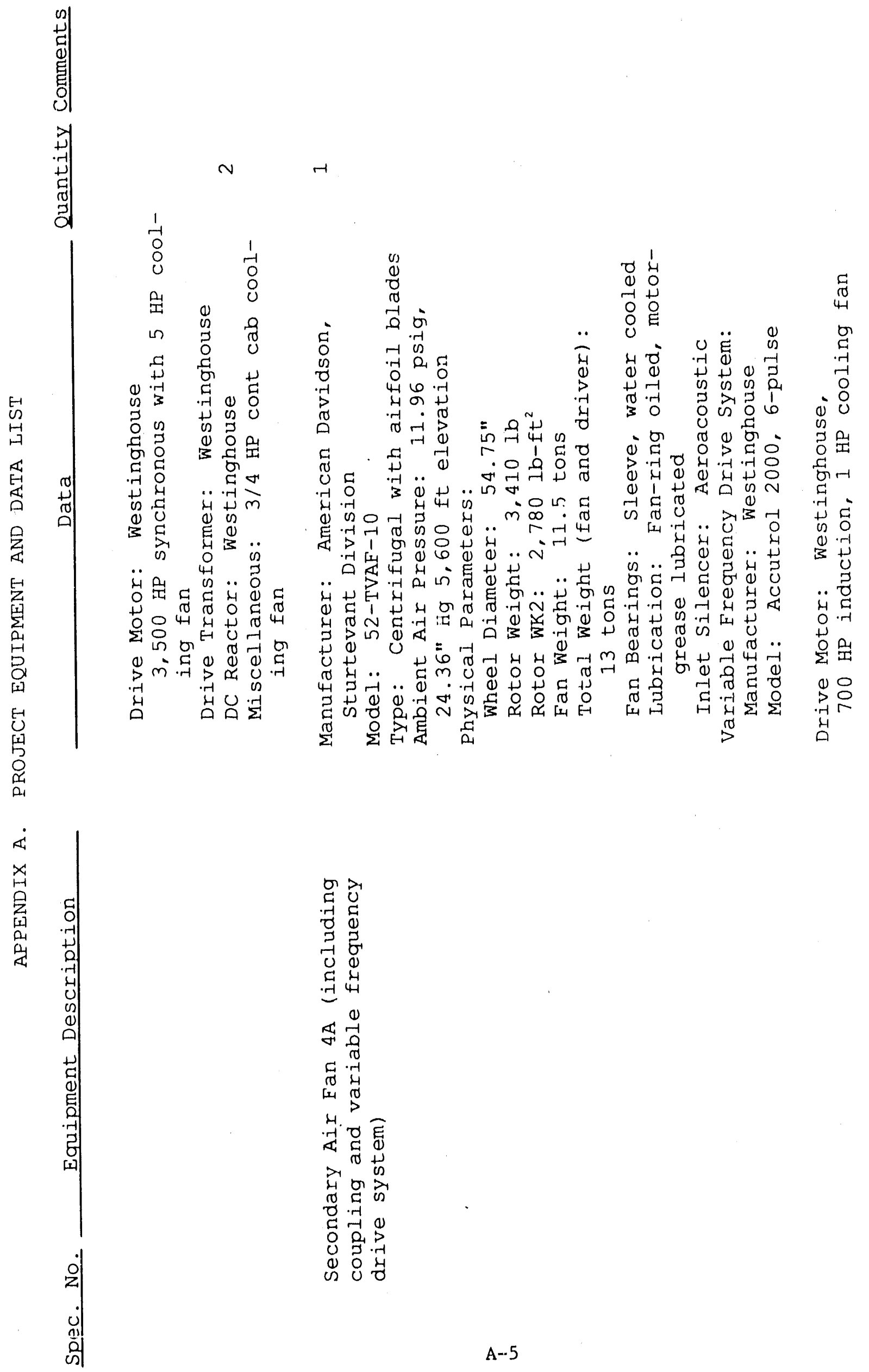



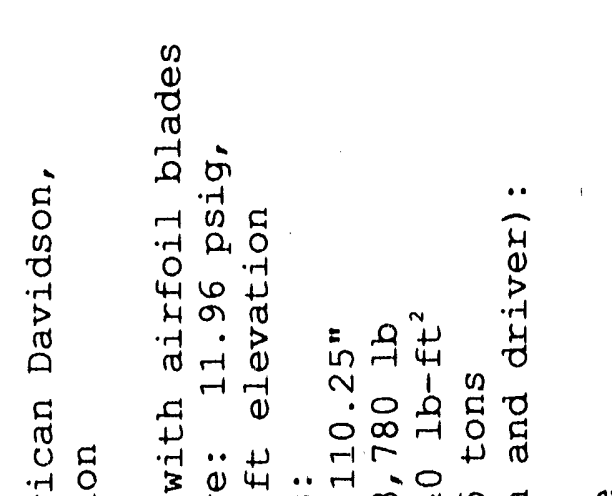

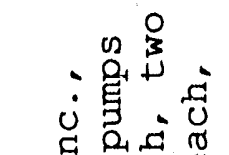

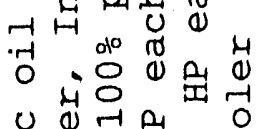

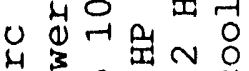
-4 पि -1 1 का क्ष त्र

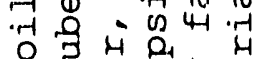

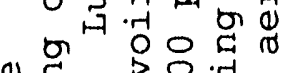
(.) . . त

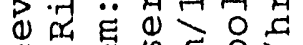
Q) बूल क $\ddot{2}$ क म

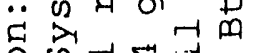

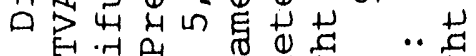

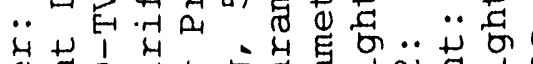

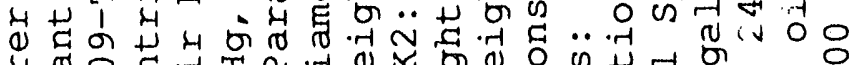

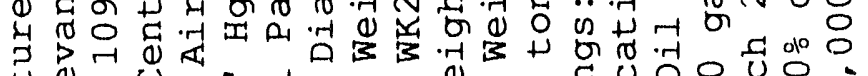

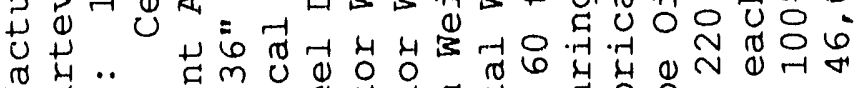

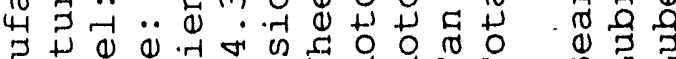

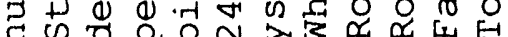
而 足是 定

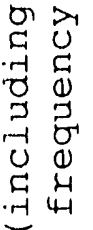
ब
c.
(4) मू
H出
范
ठ大
ه.
$\begin{array}{lll}0 & -1 & 0 \\ 0 & 0 & 5 \\ 0 & 0 & -1 \\ 0 & 0 & 4 \\ 11 & 0 & 0\end{array}$ 


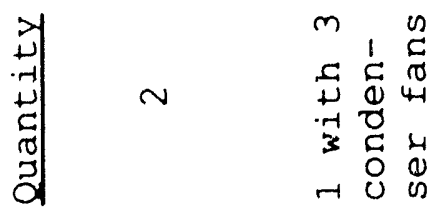
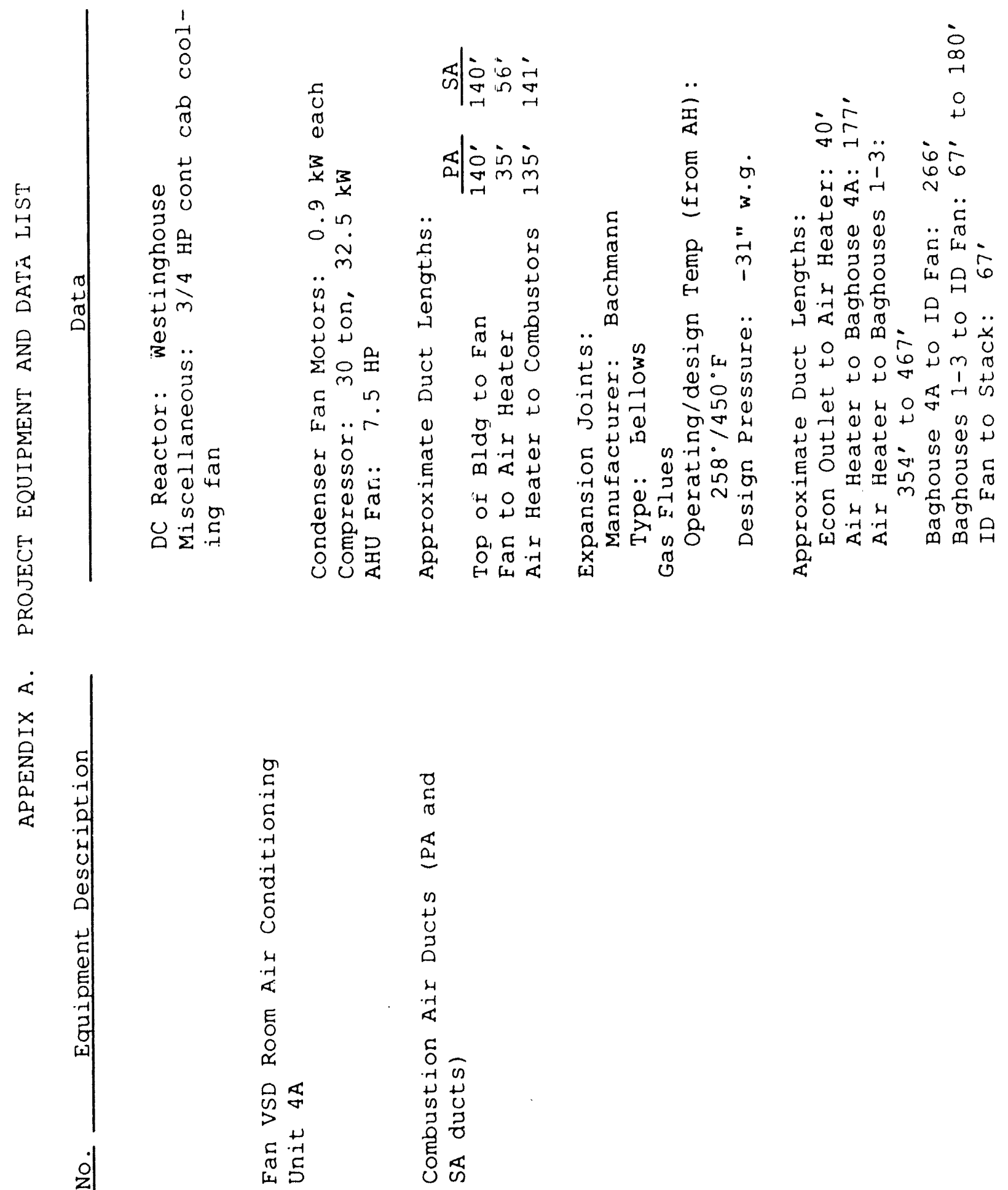


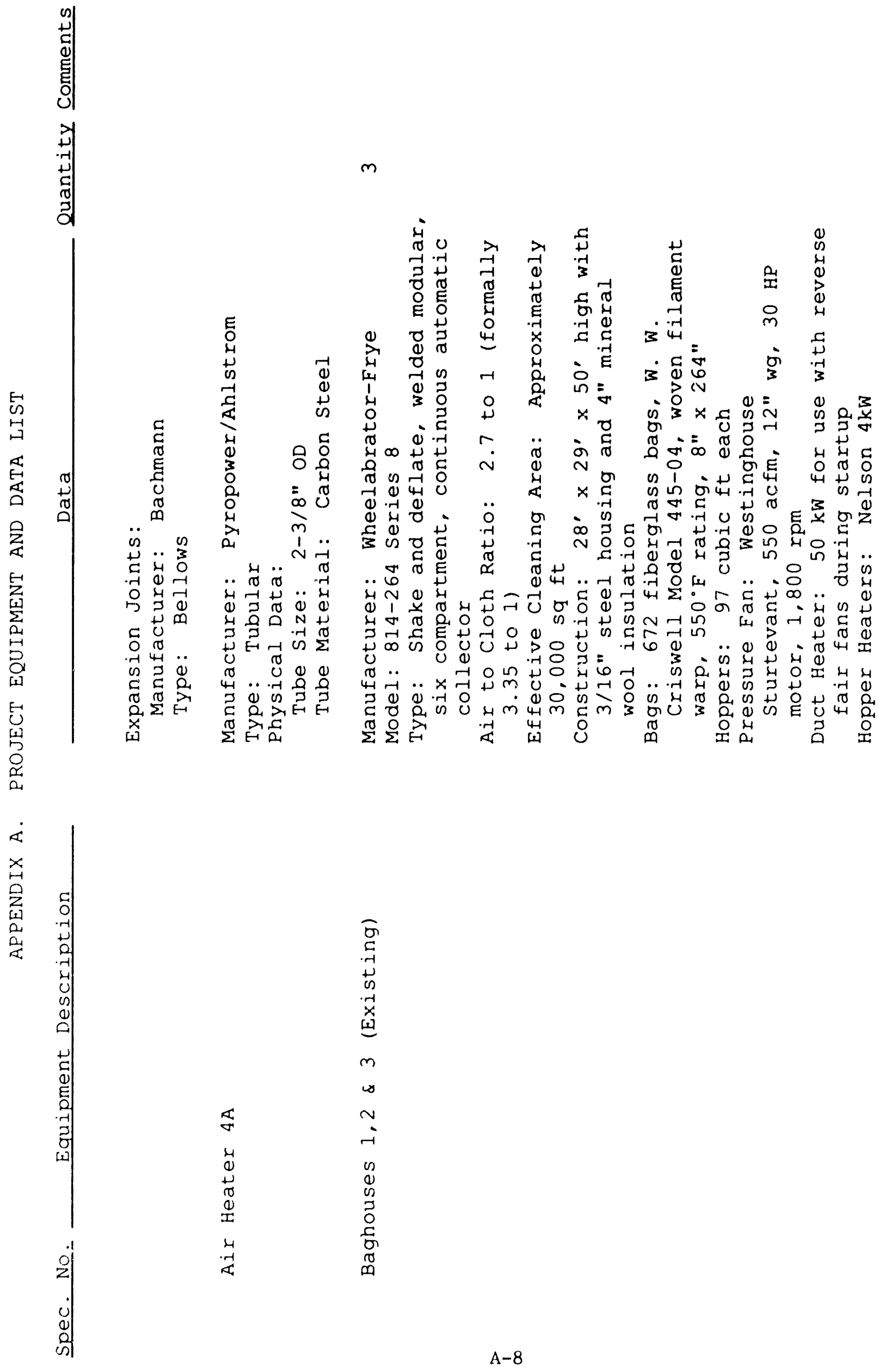


0.

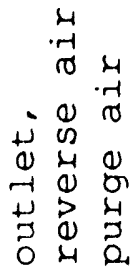

$\sim \sim \sim N$

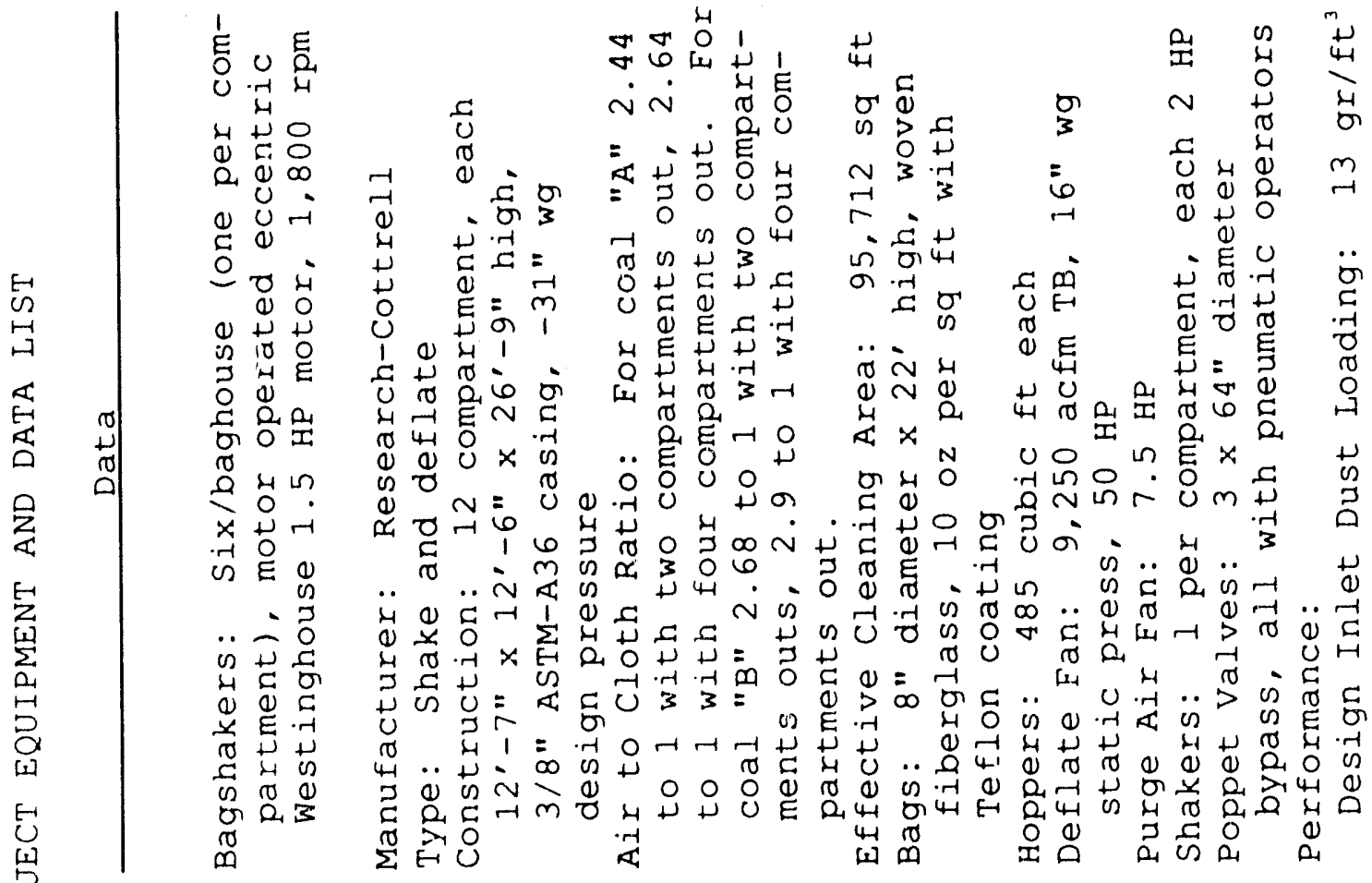




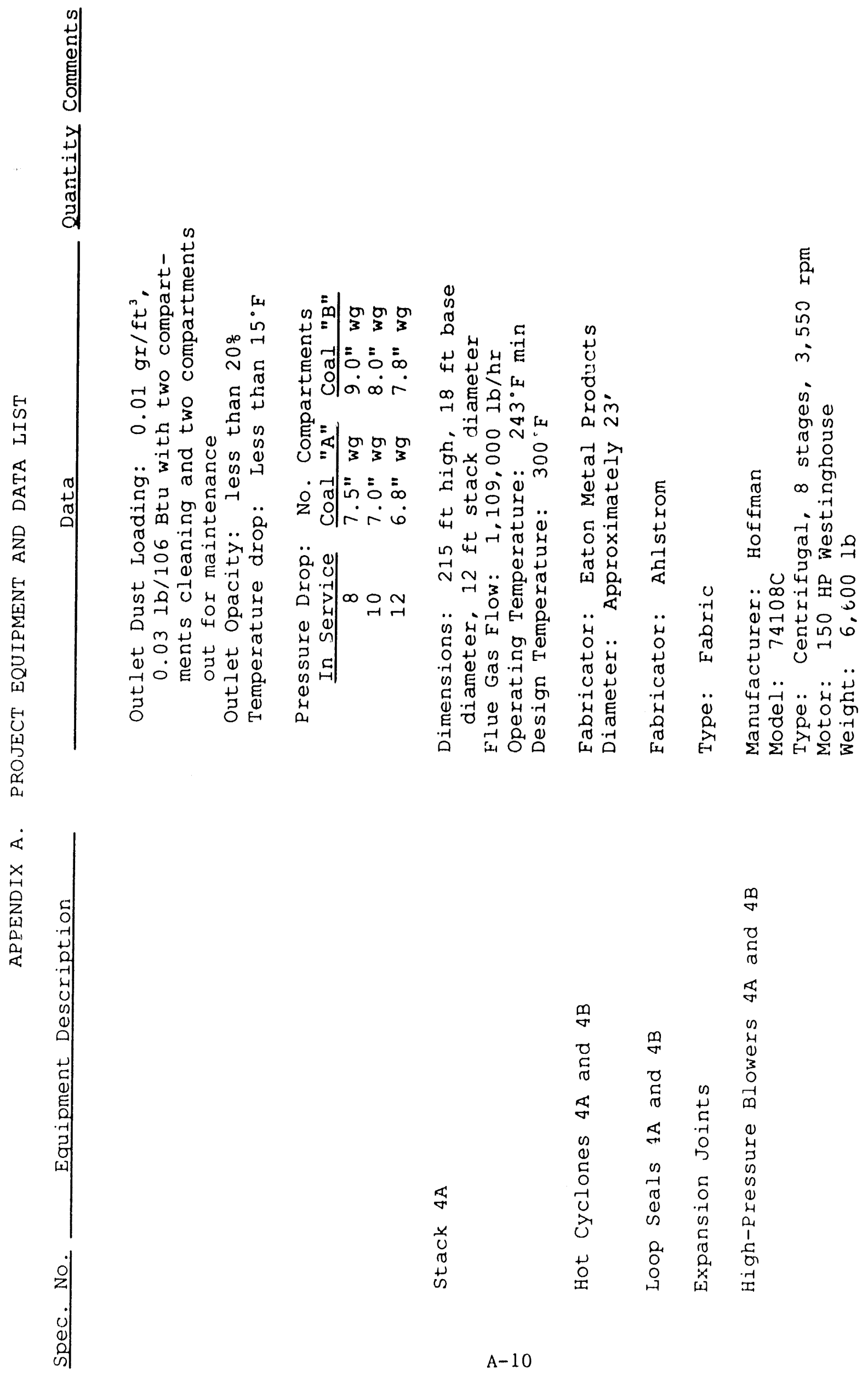




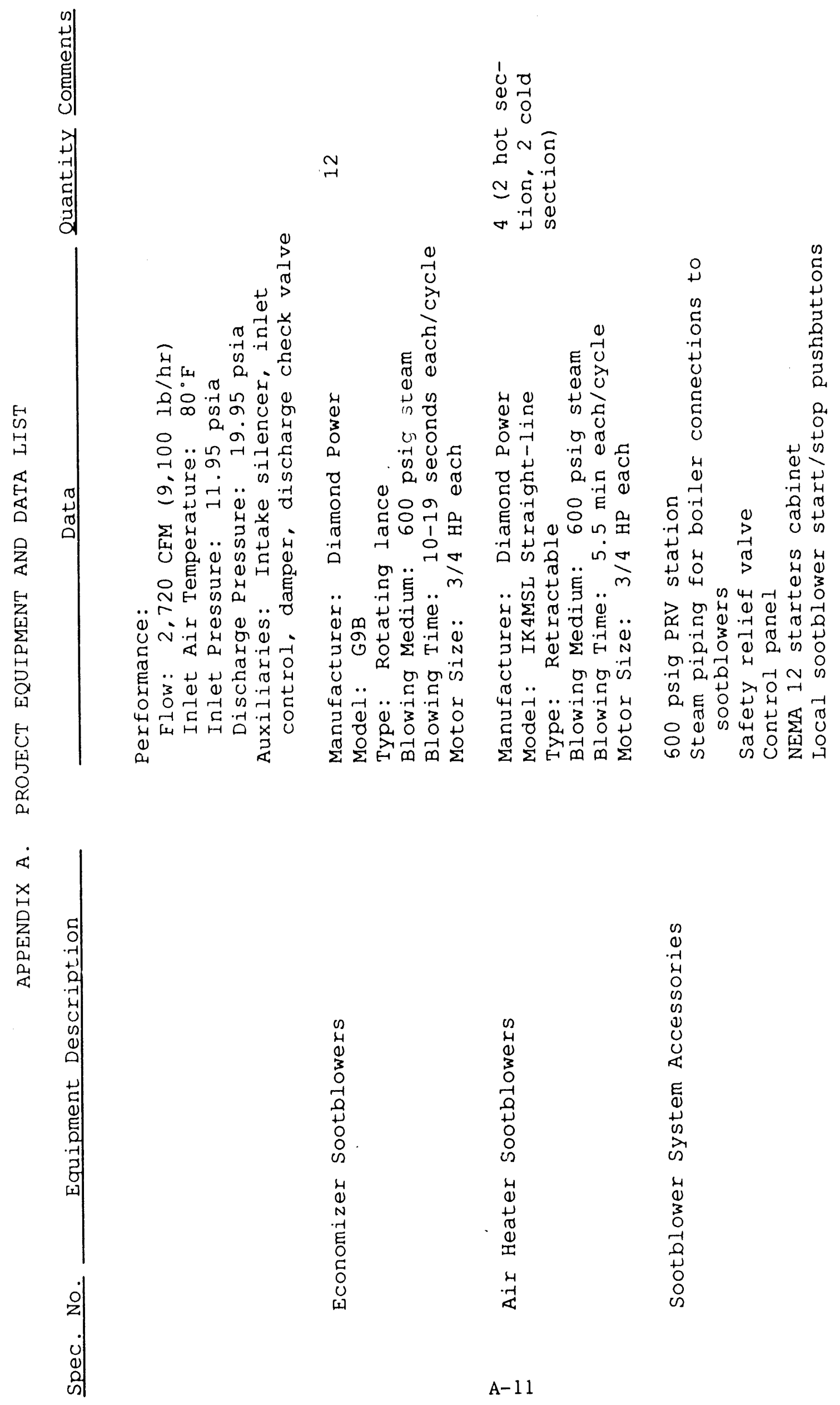




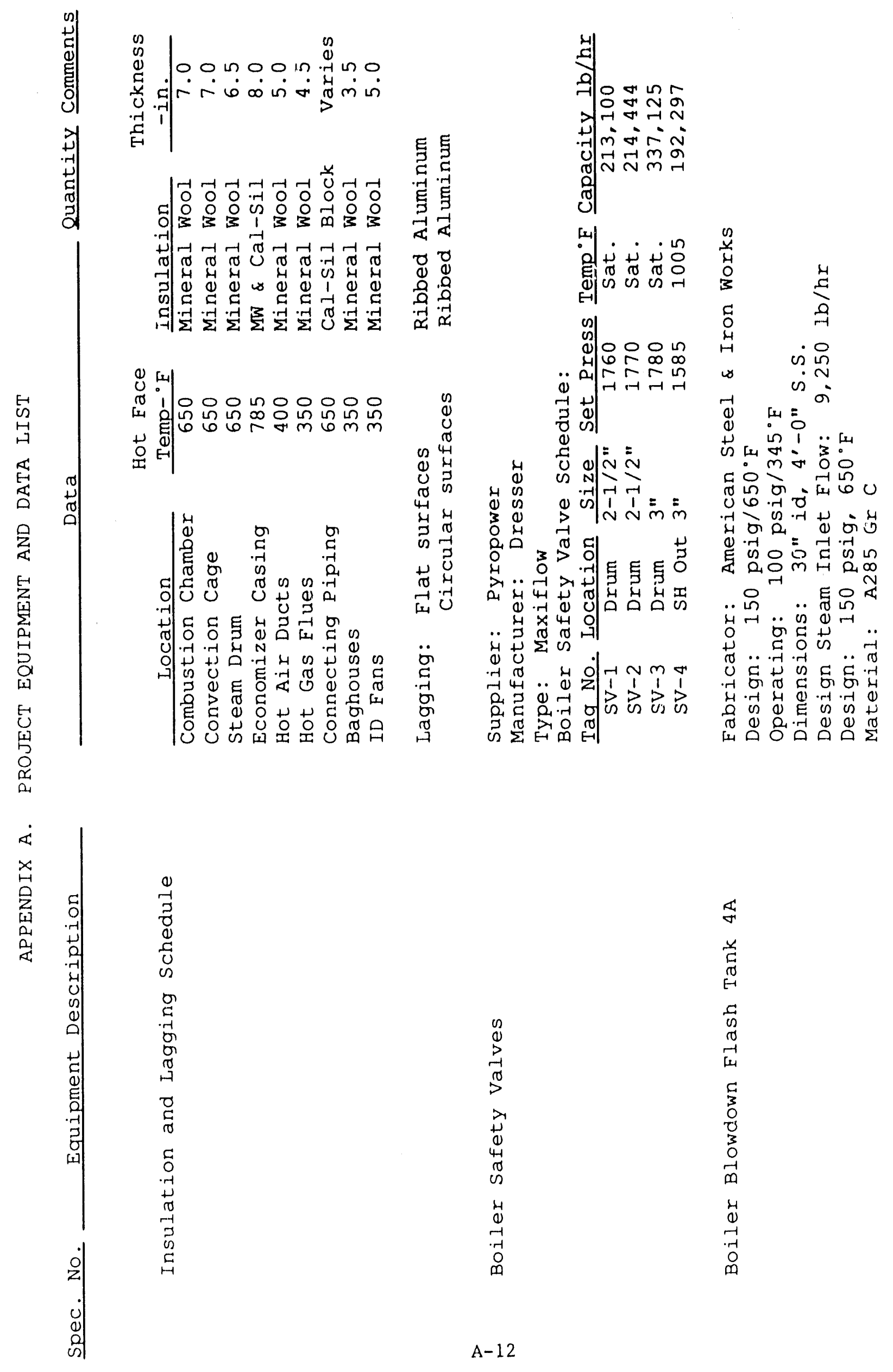




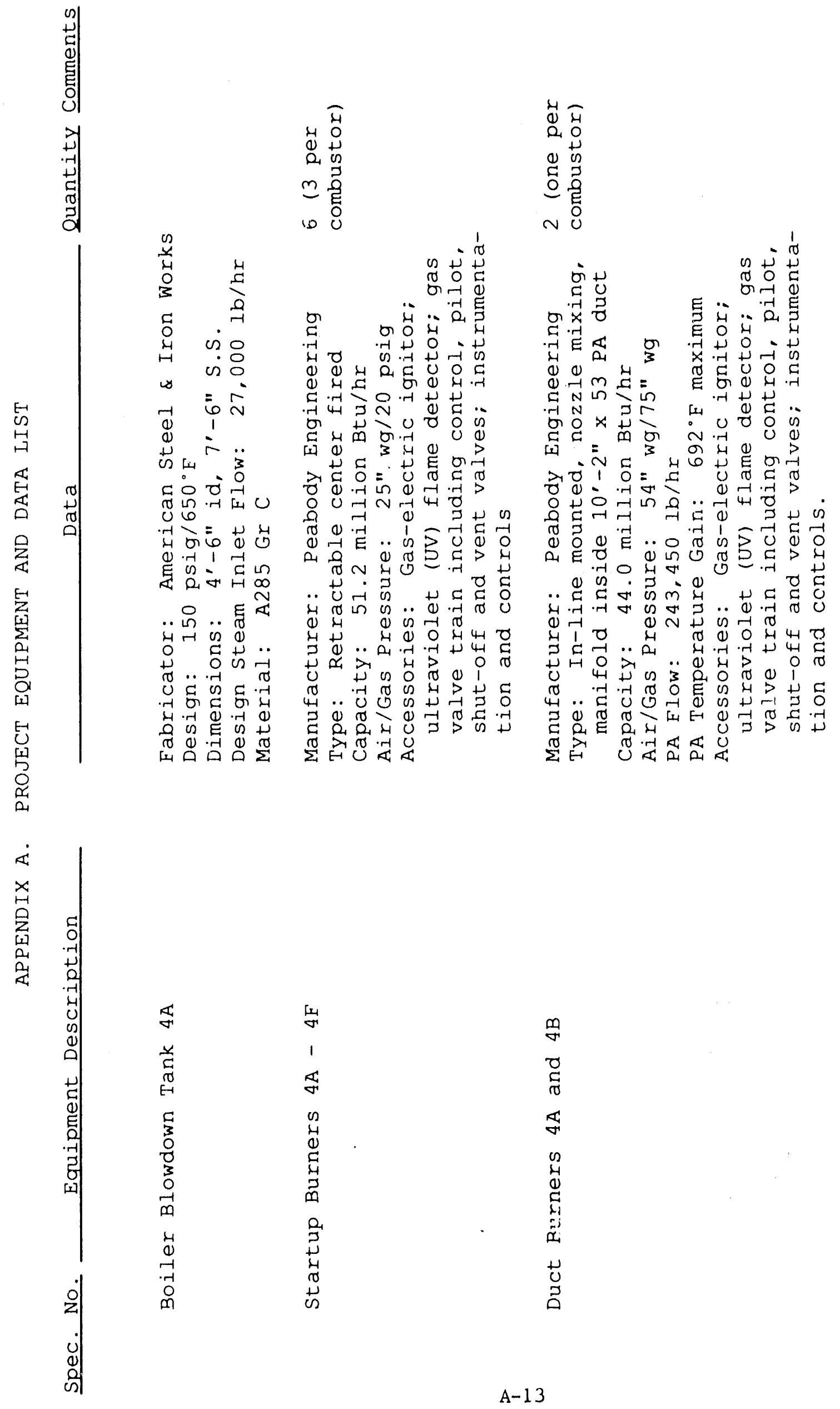




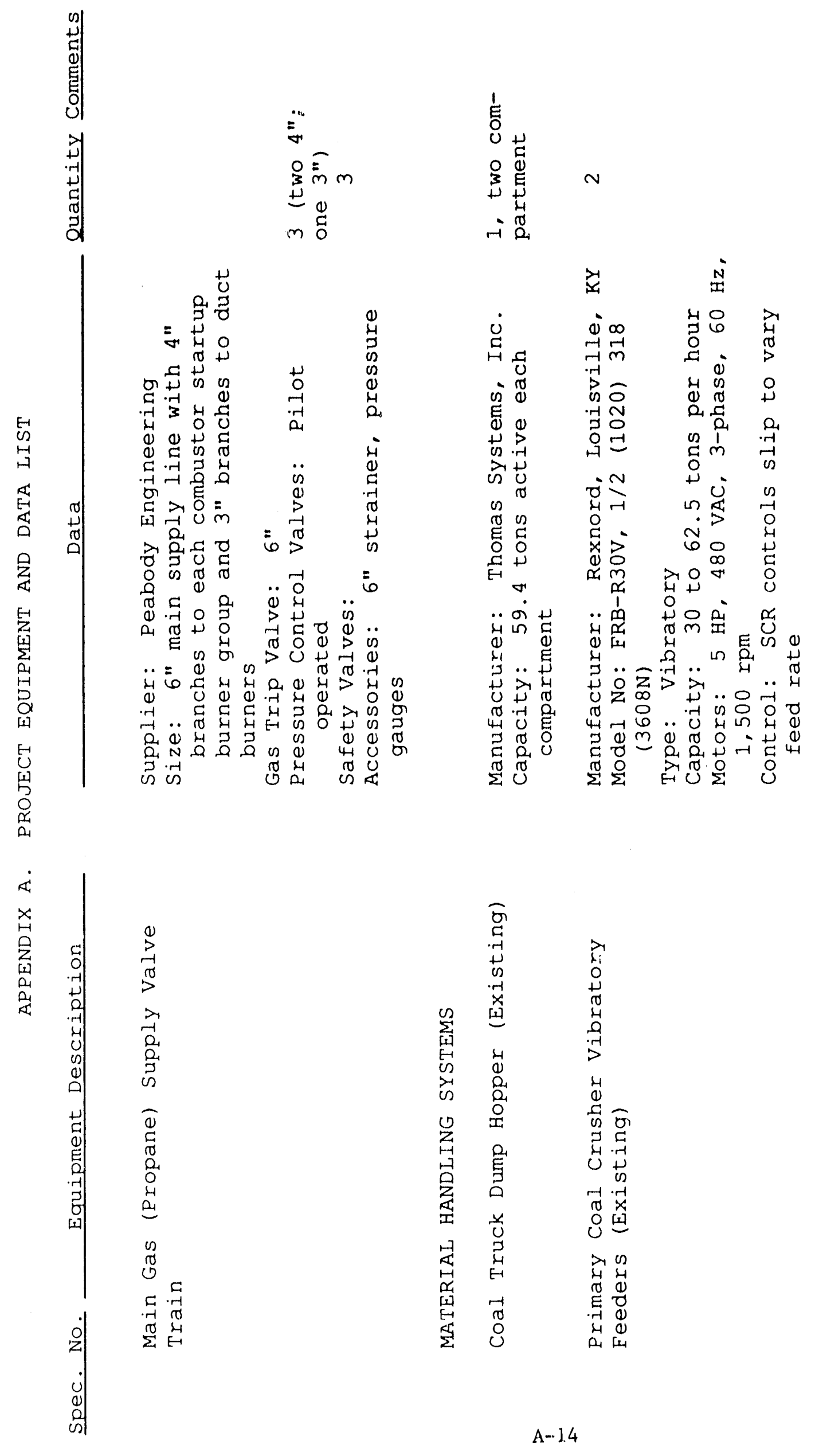




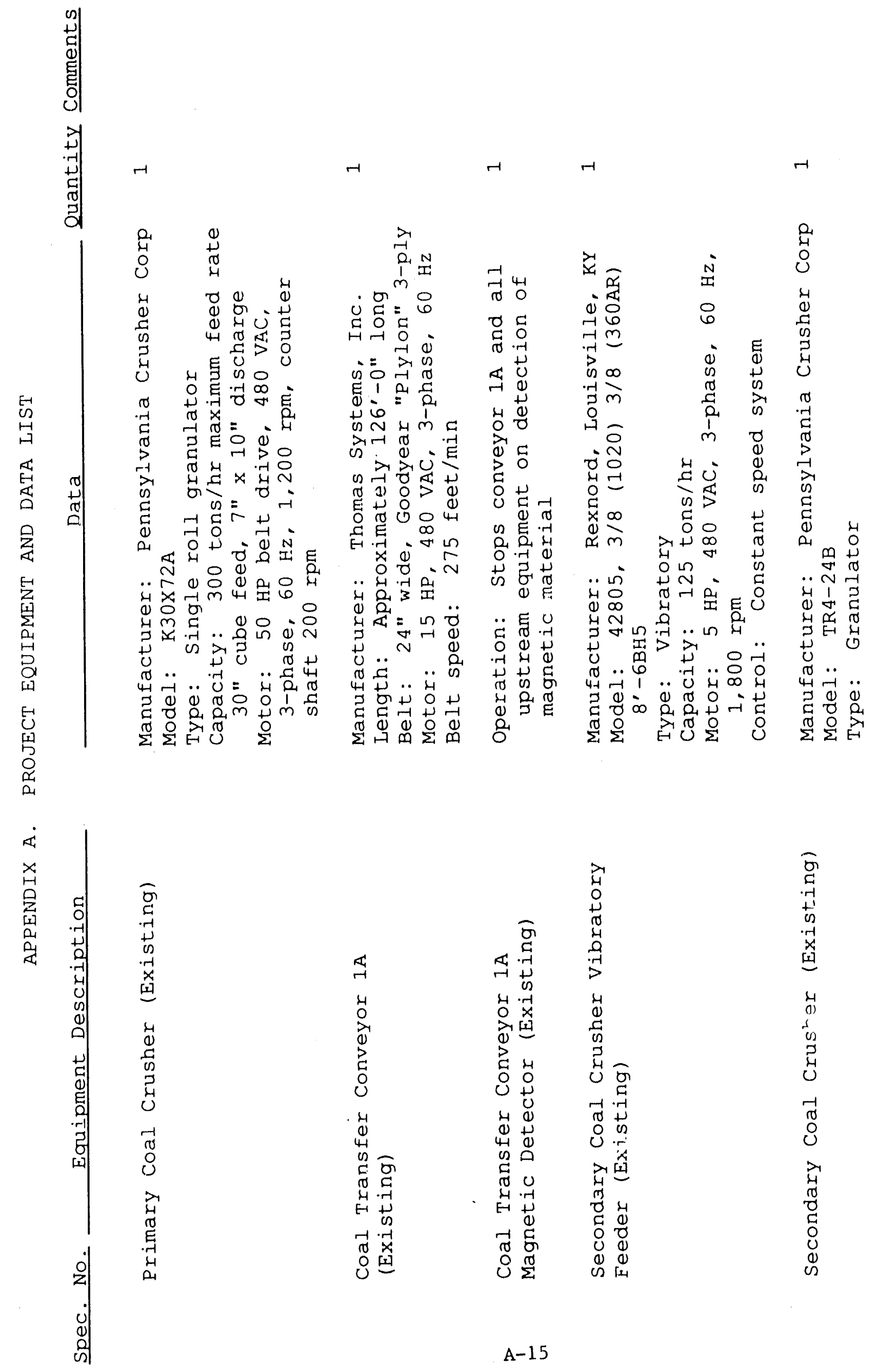




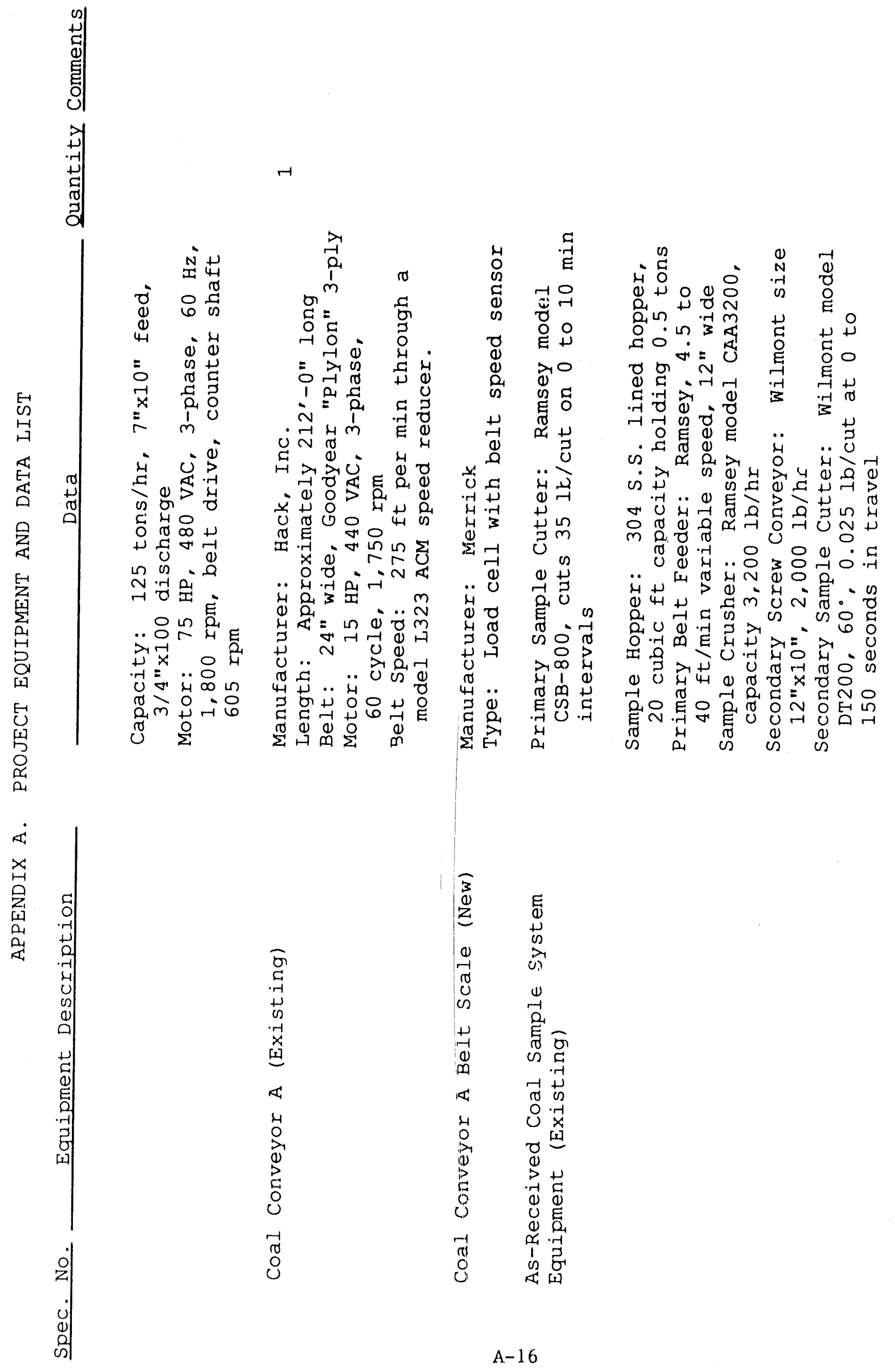




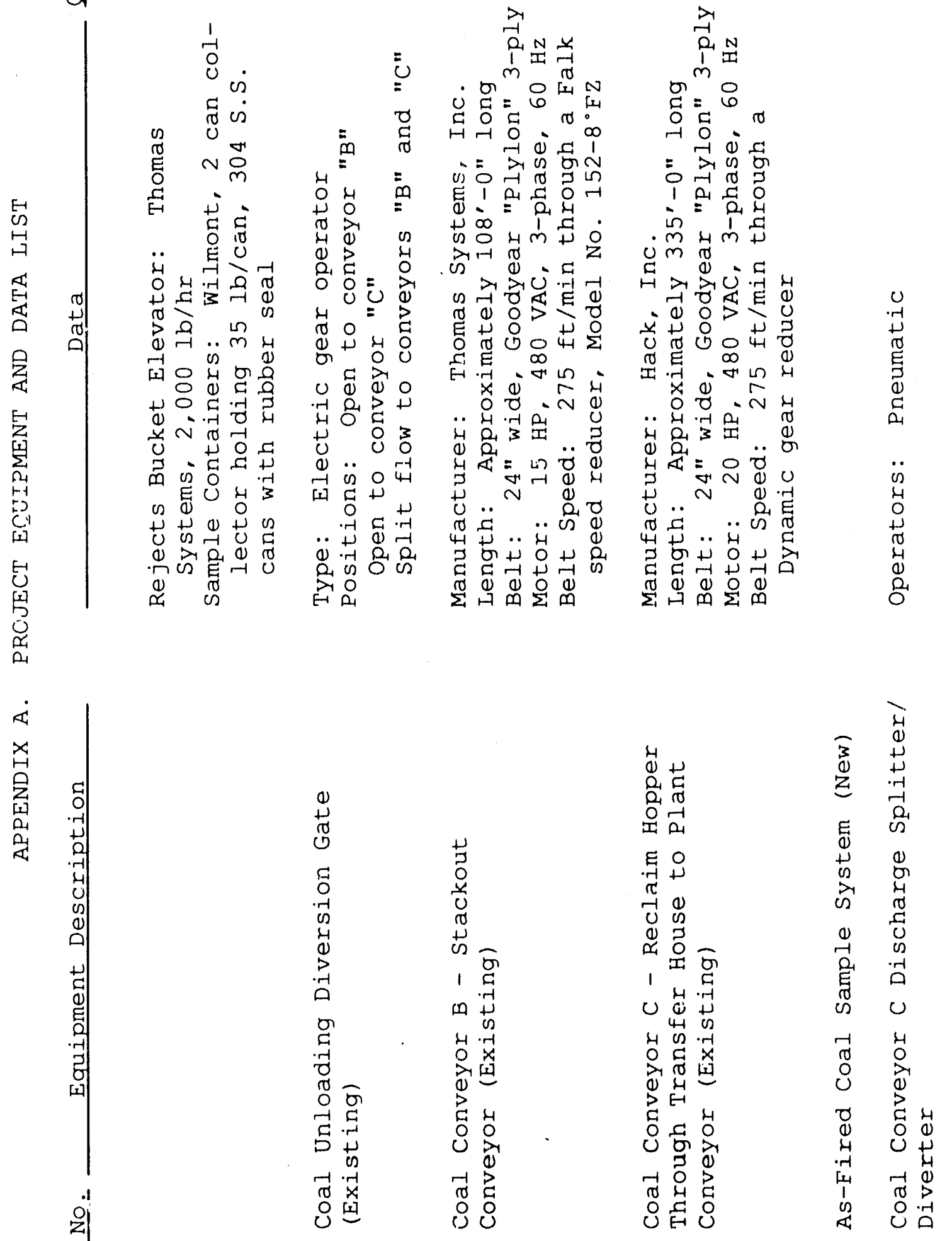


$-$

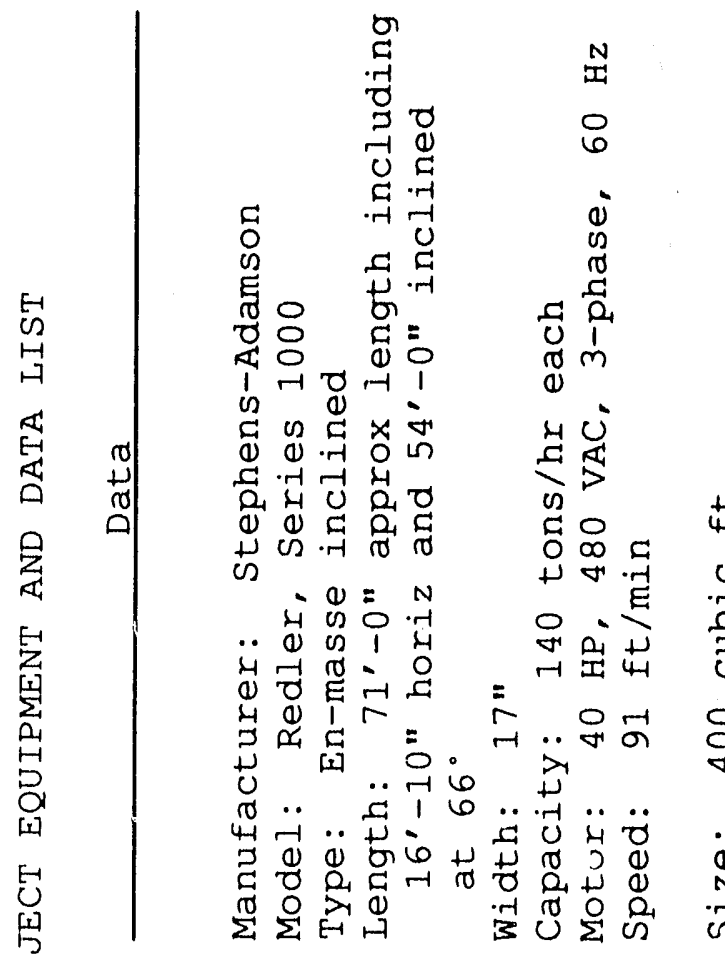

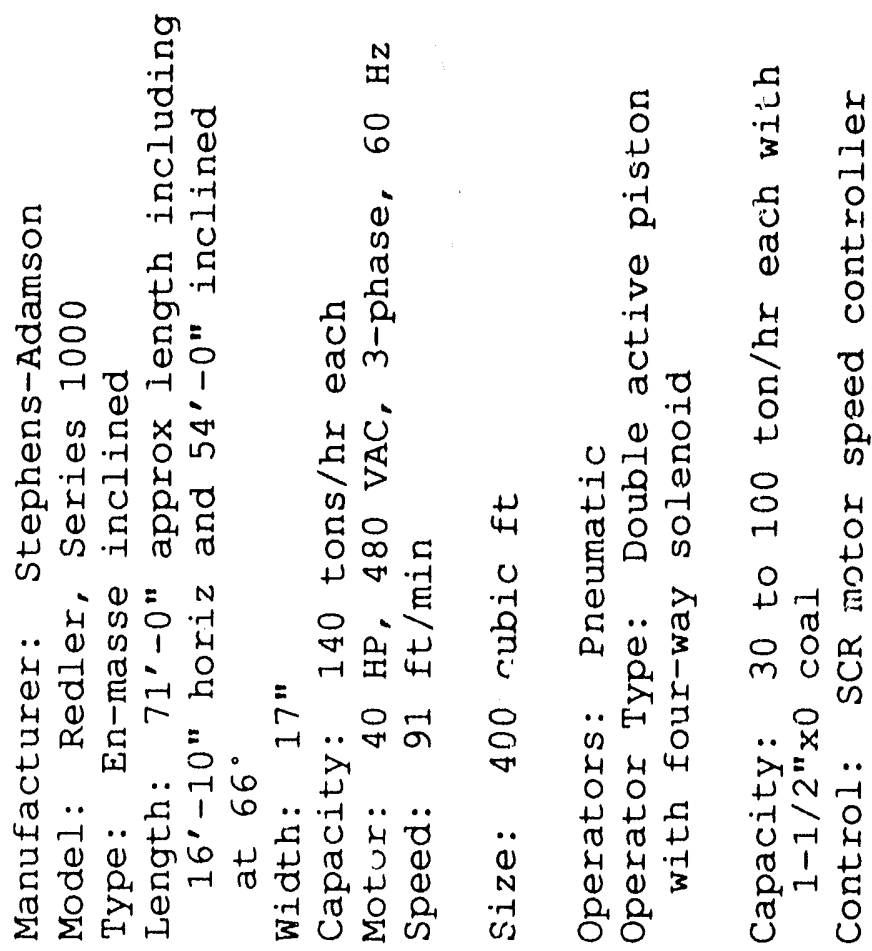

$N$

$N$
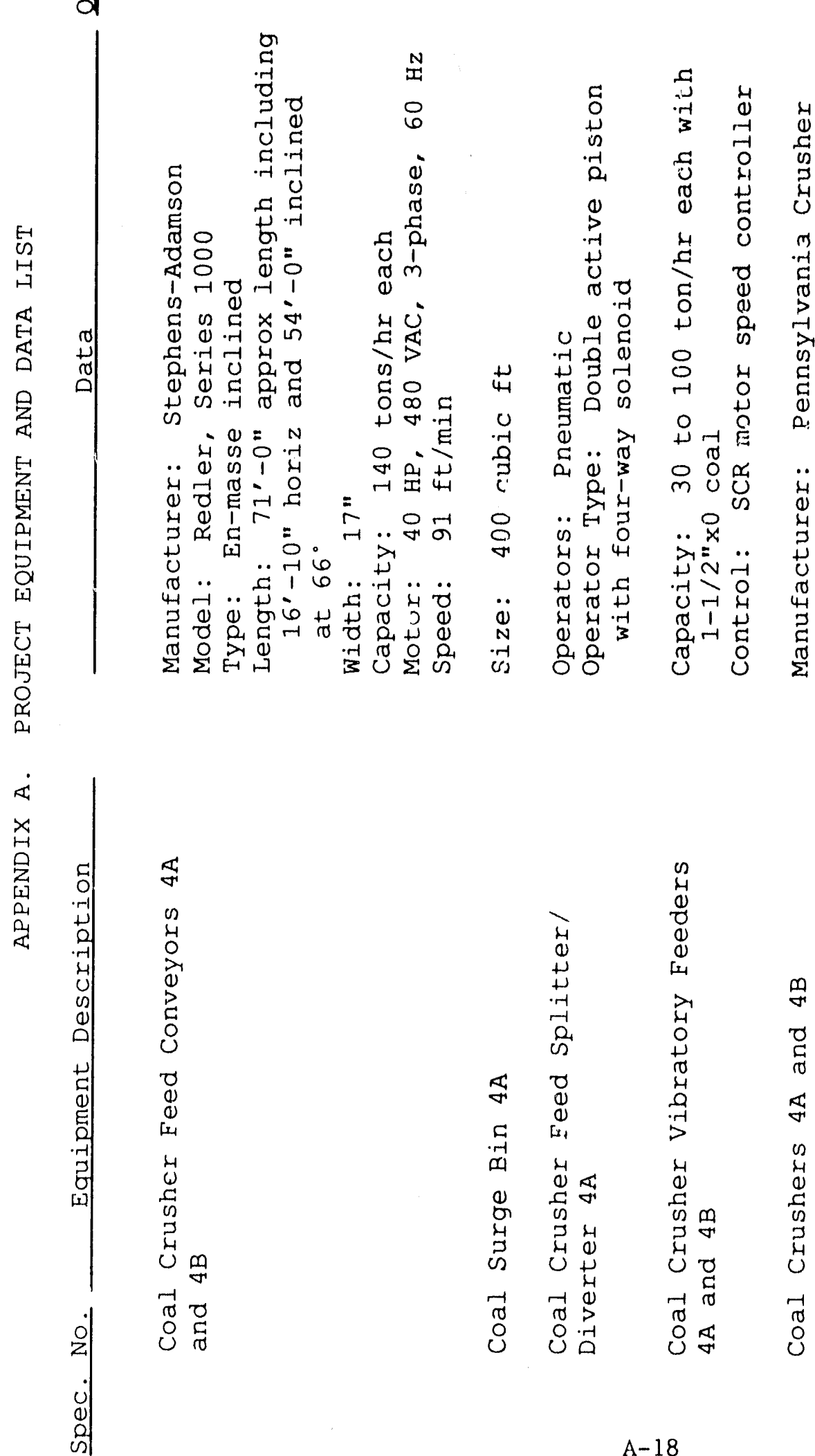

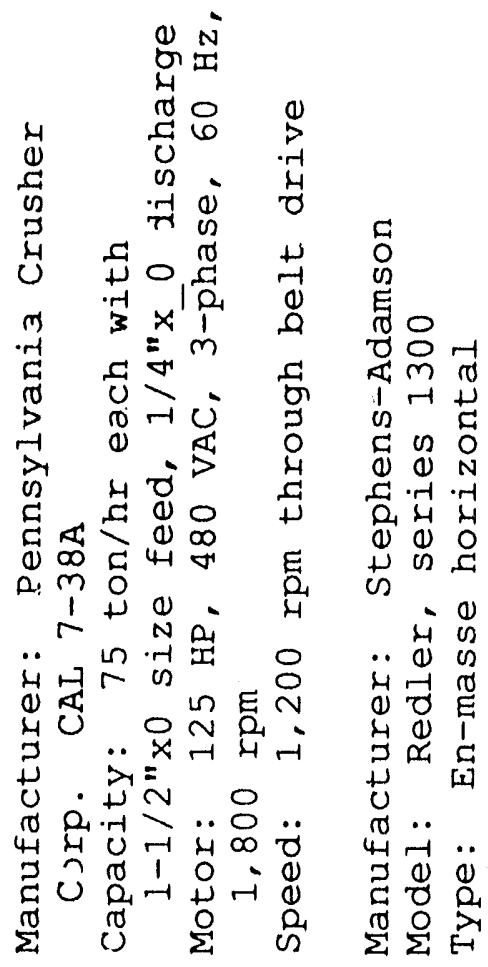




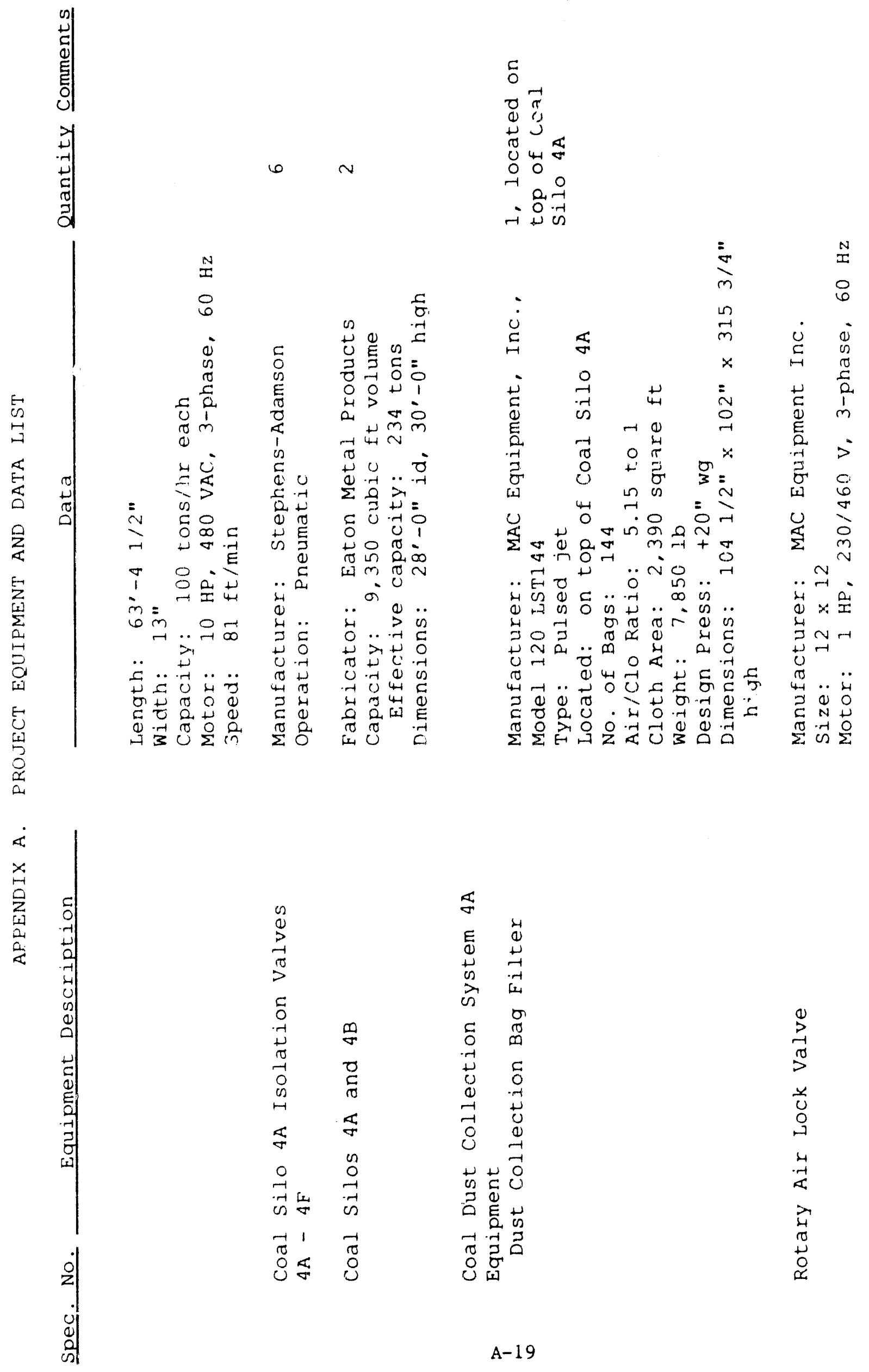




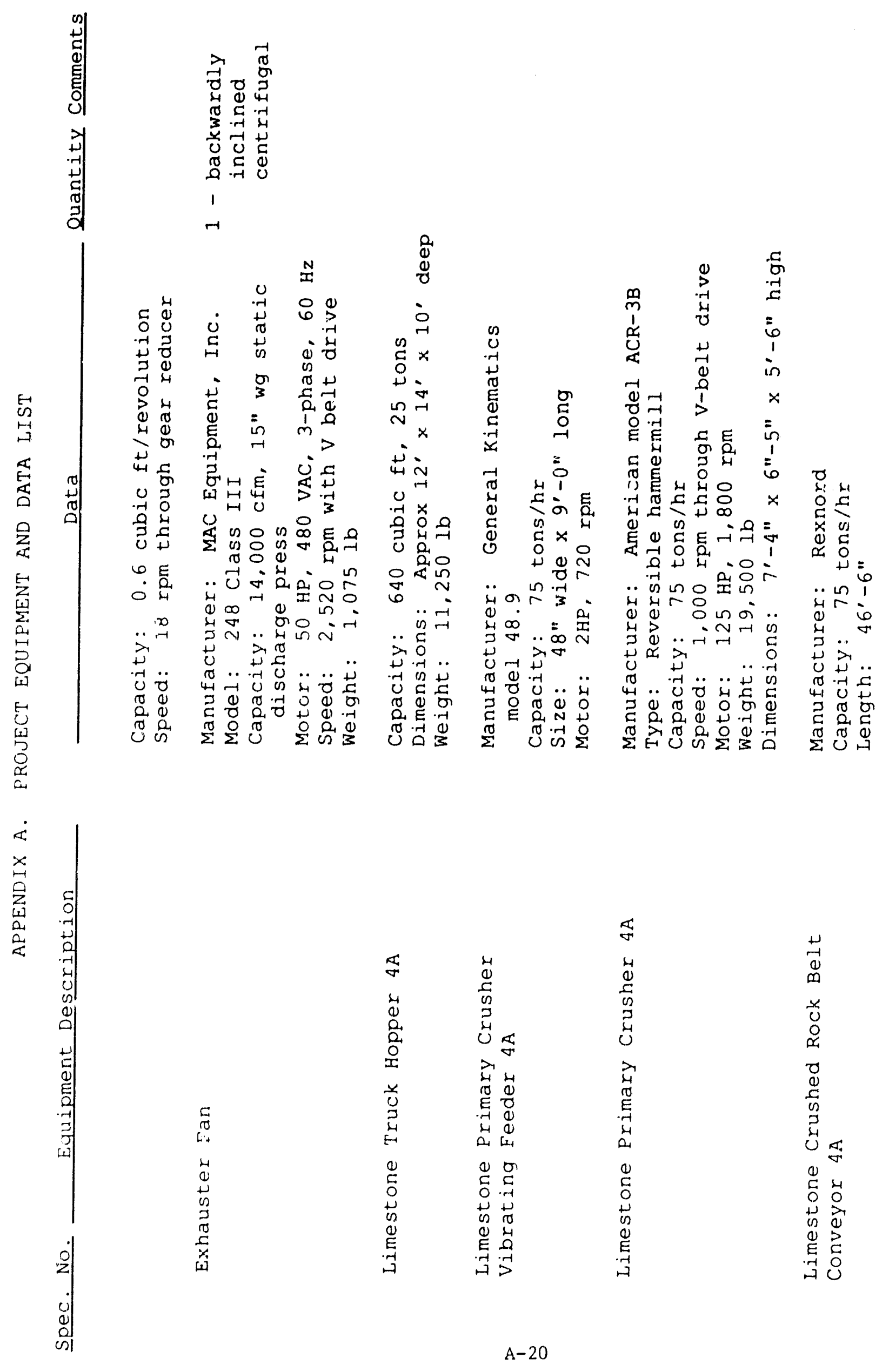




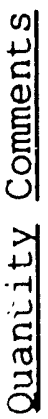
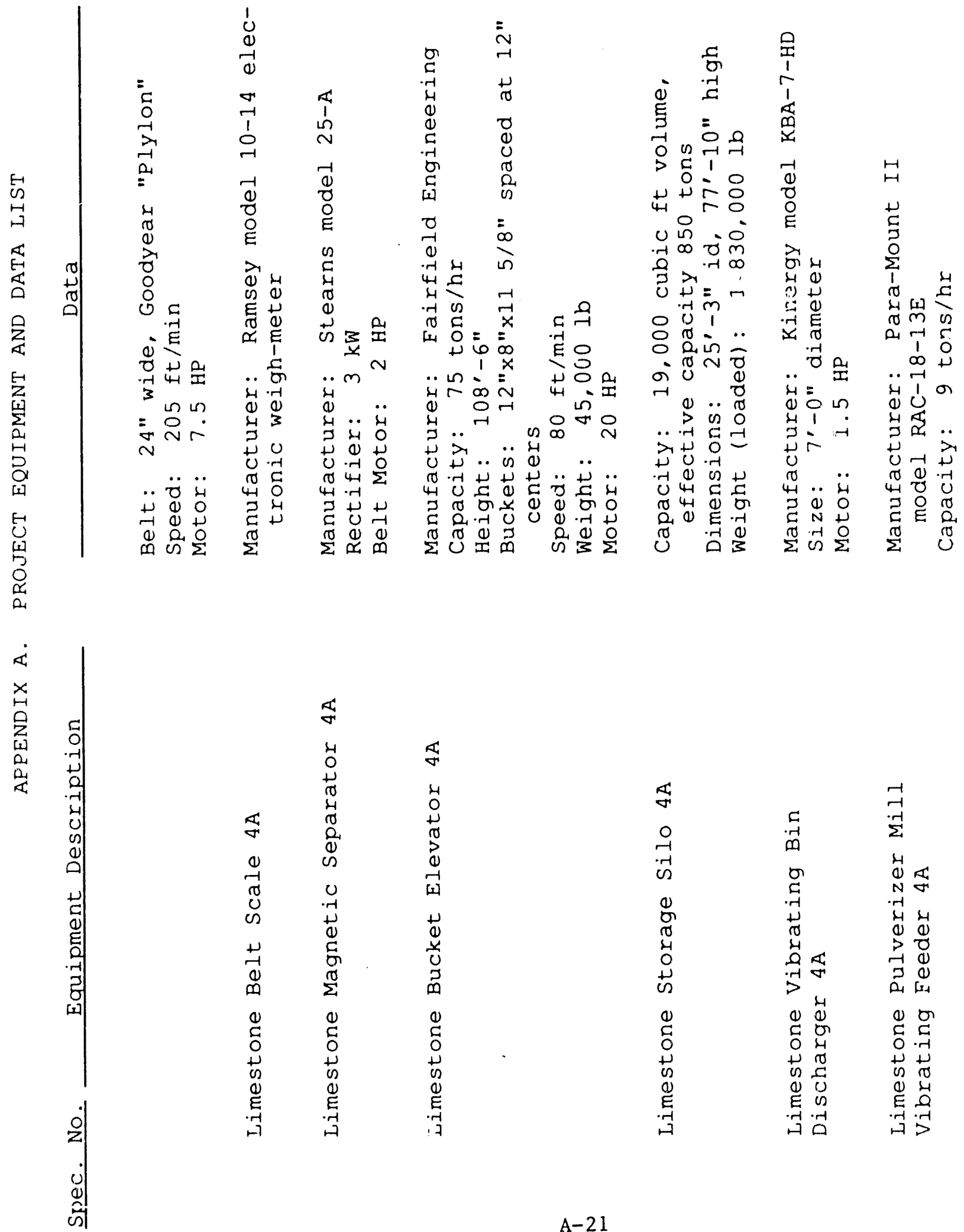

0
0
0
-1
-1
0
0
0
0
0
0
0
0
0
0
0
0
0
0
0
-7
-1

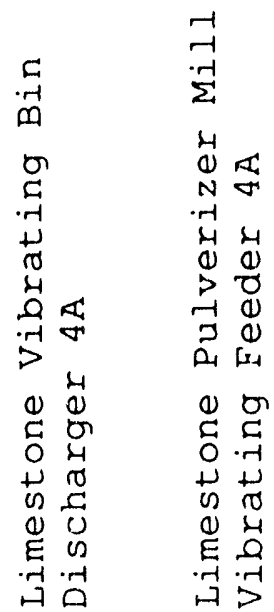




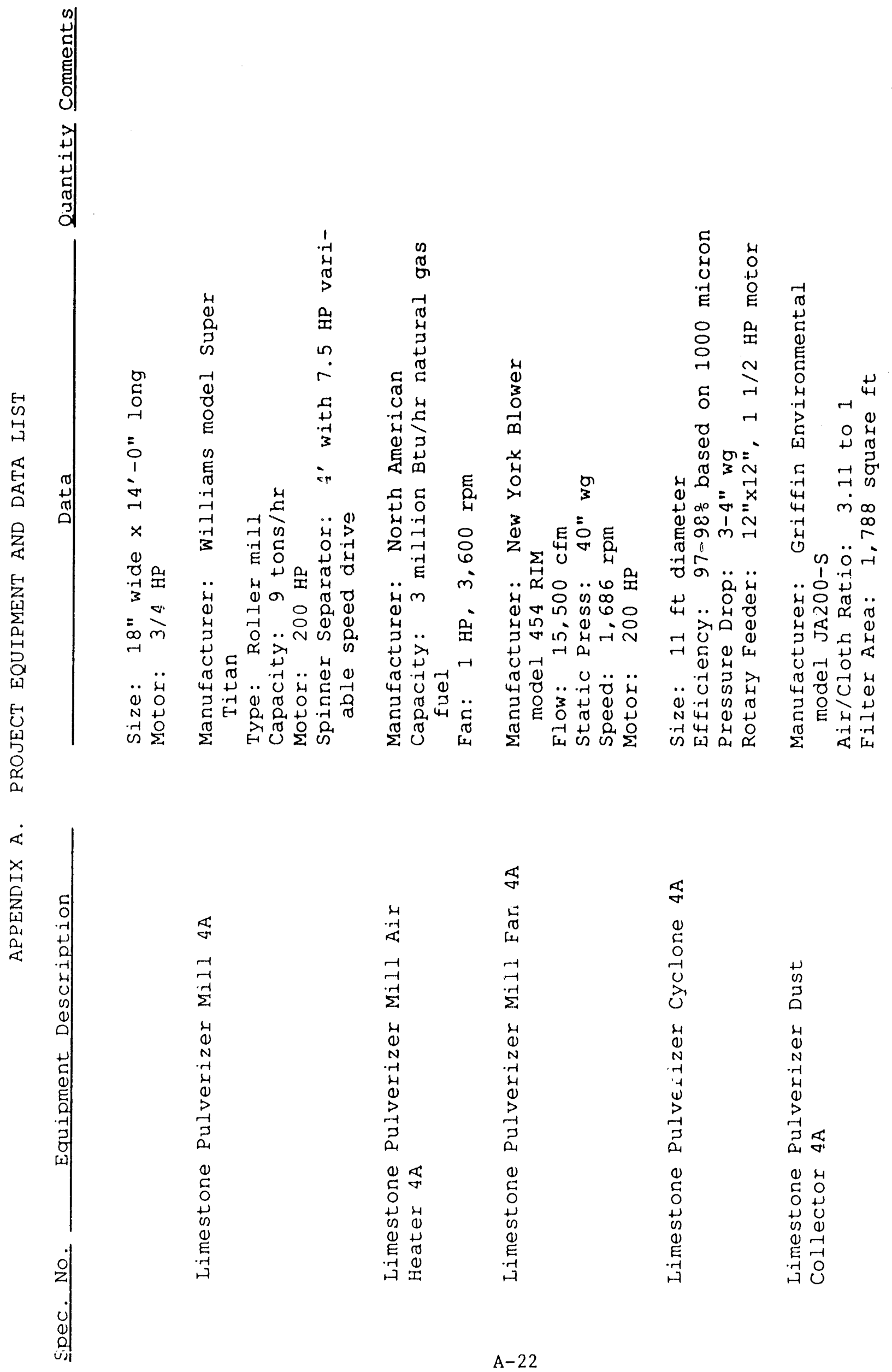




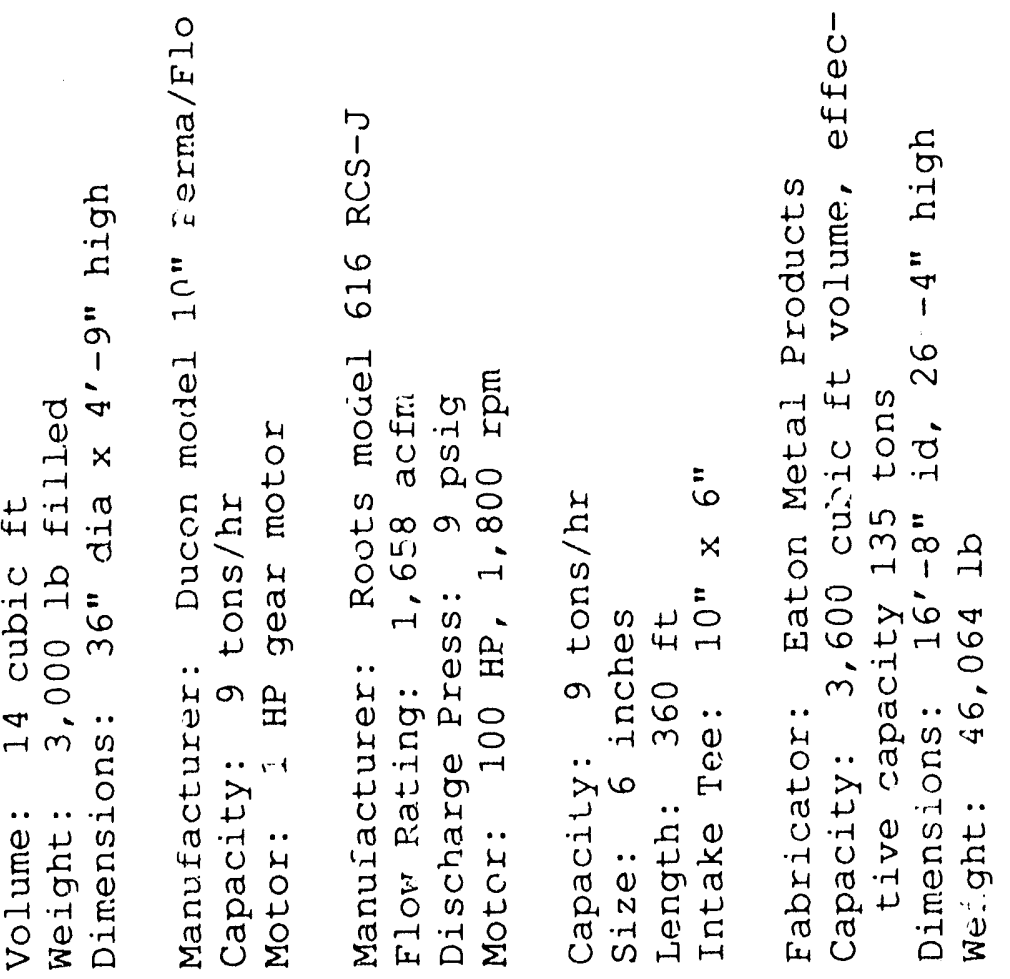

5
0
0
0
0

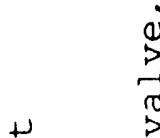$$
\text { 感 }
$$

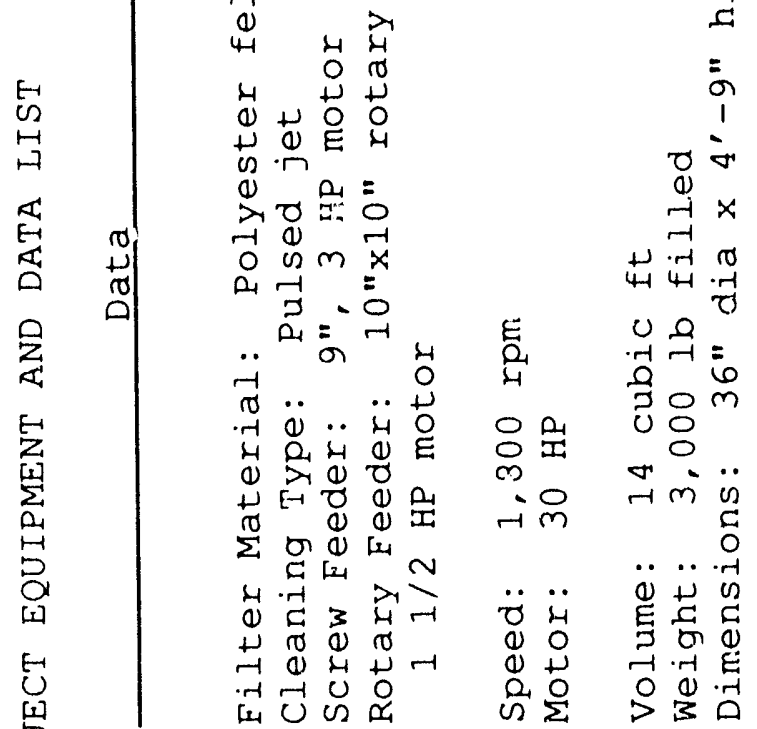

舀

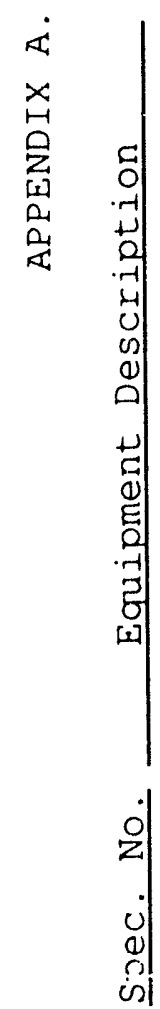

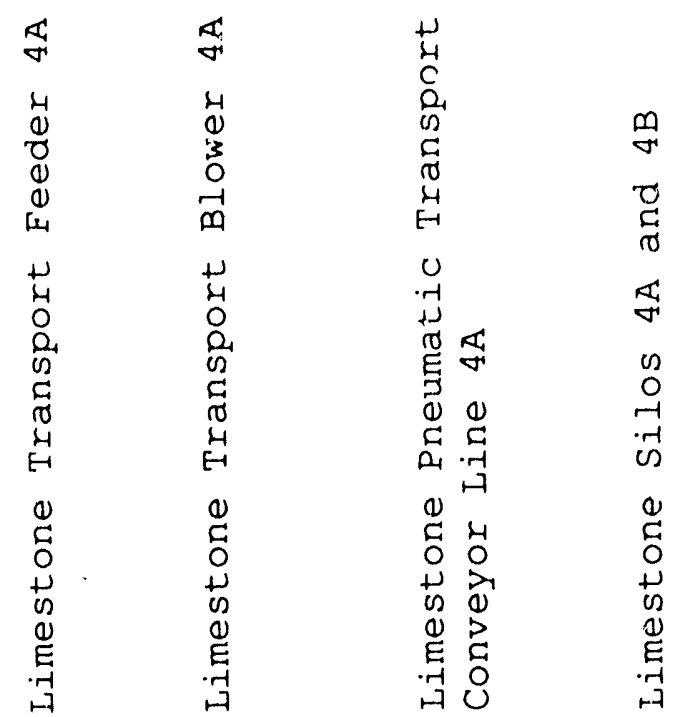

A -23 
$m+1$

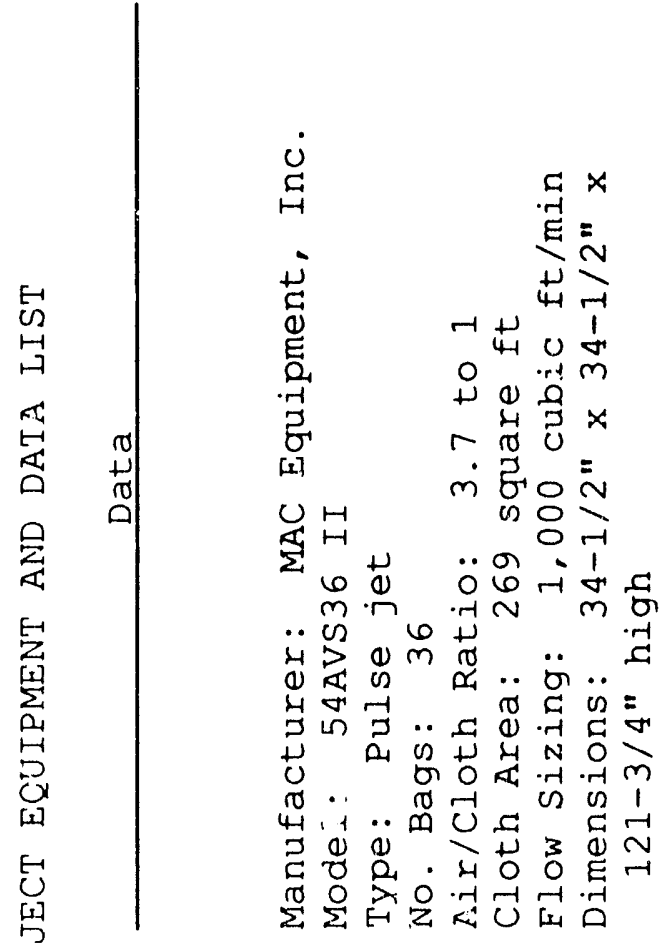

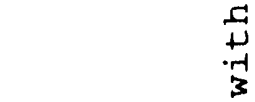

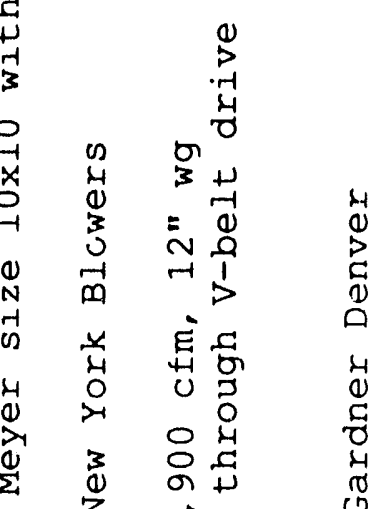

以

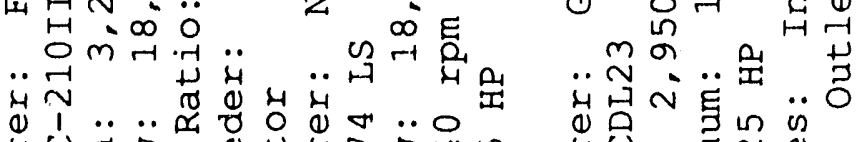

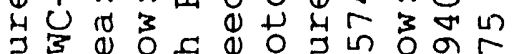

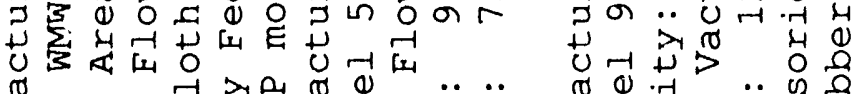

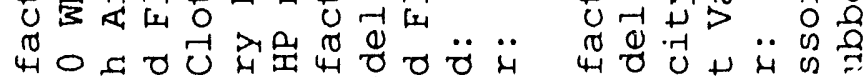

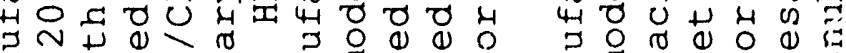
E ${ }^{\circ} 0$ मे

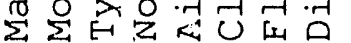




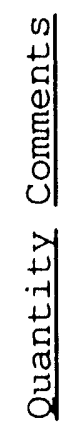
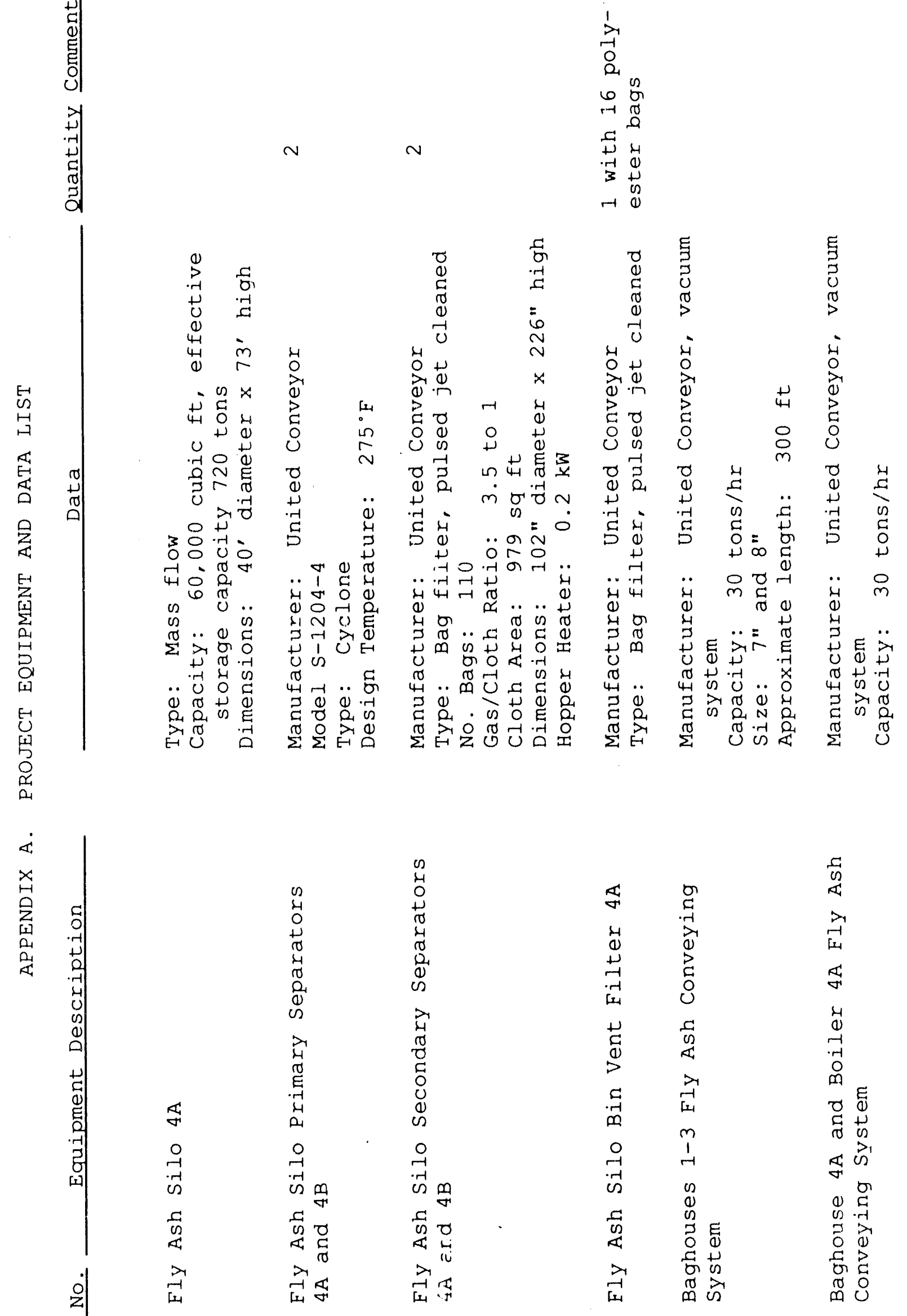


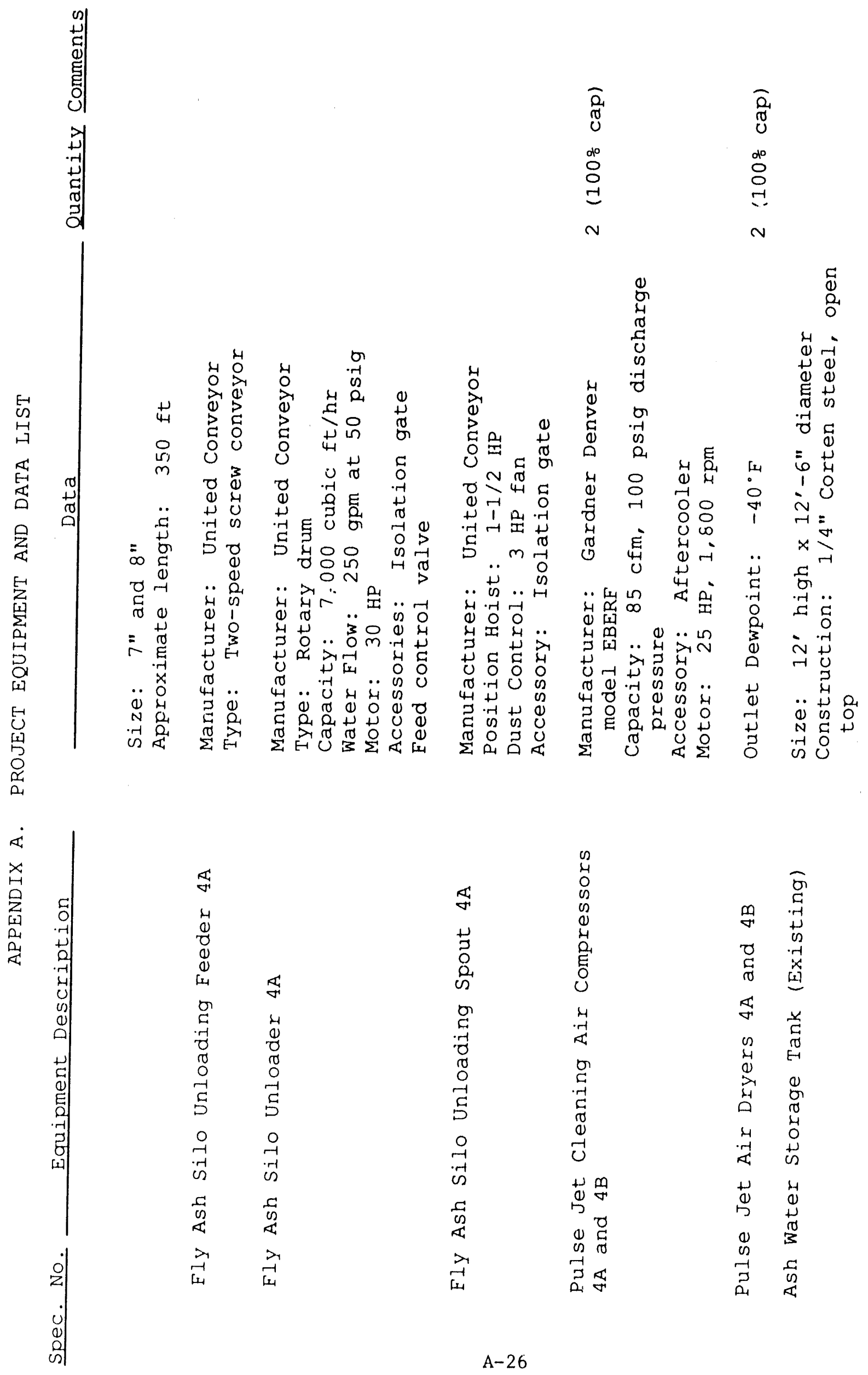




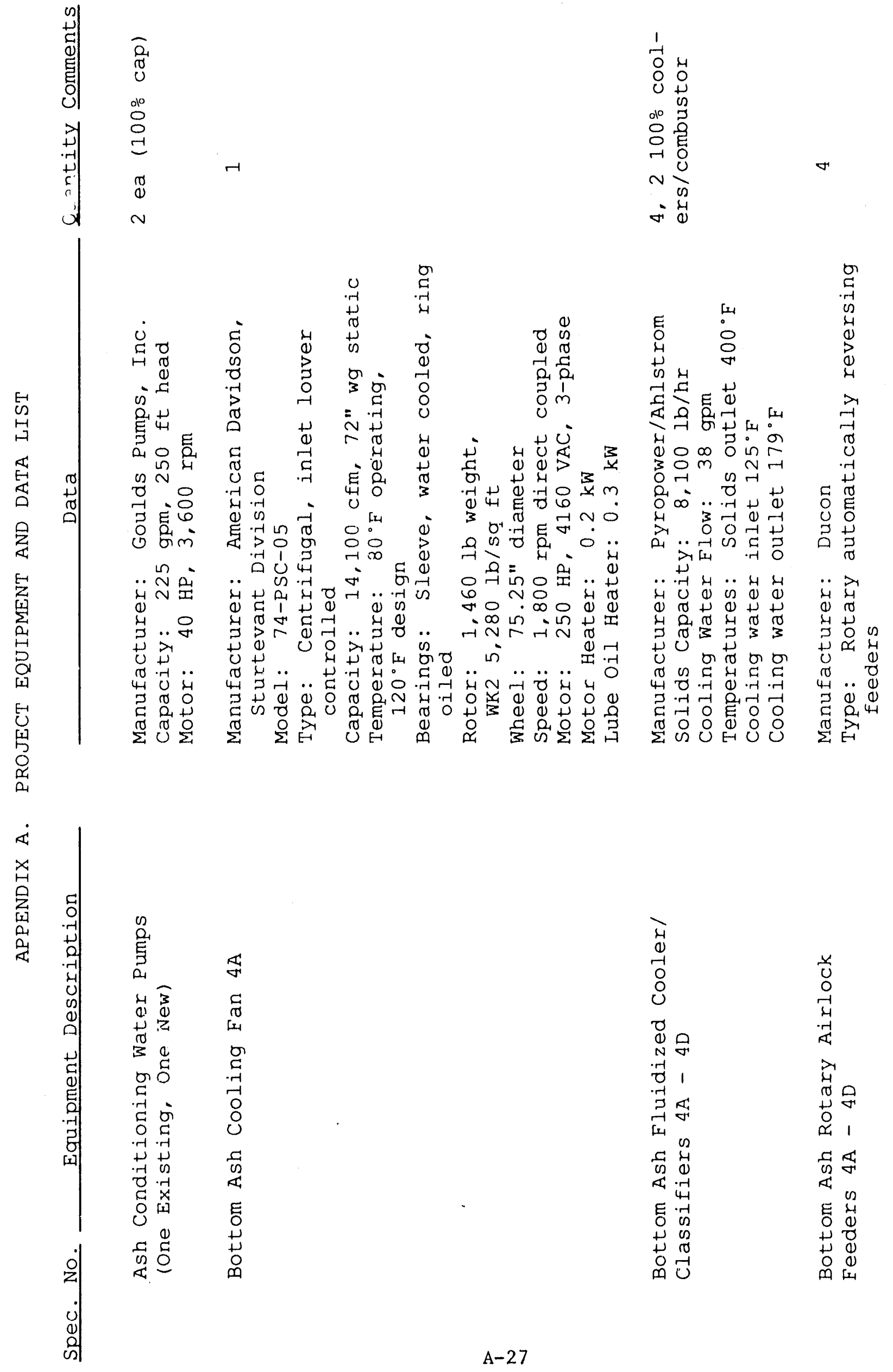




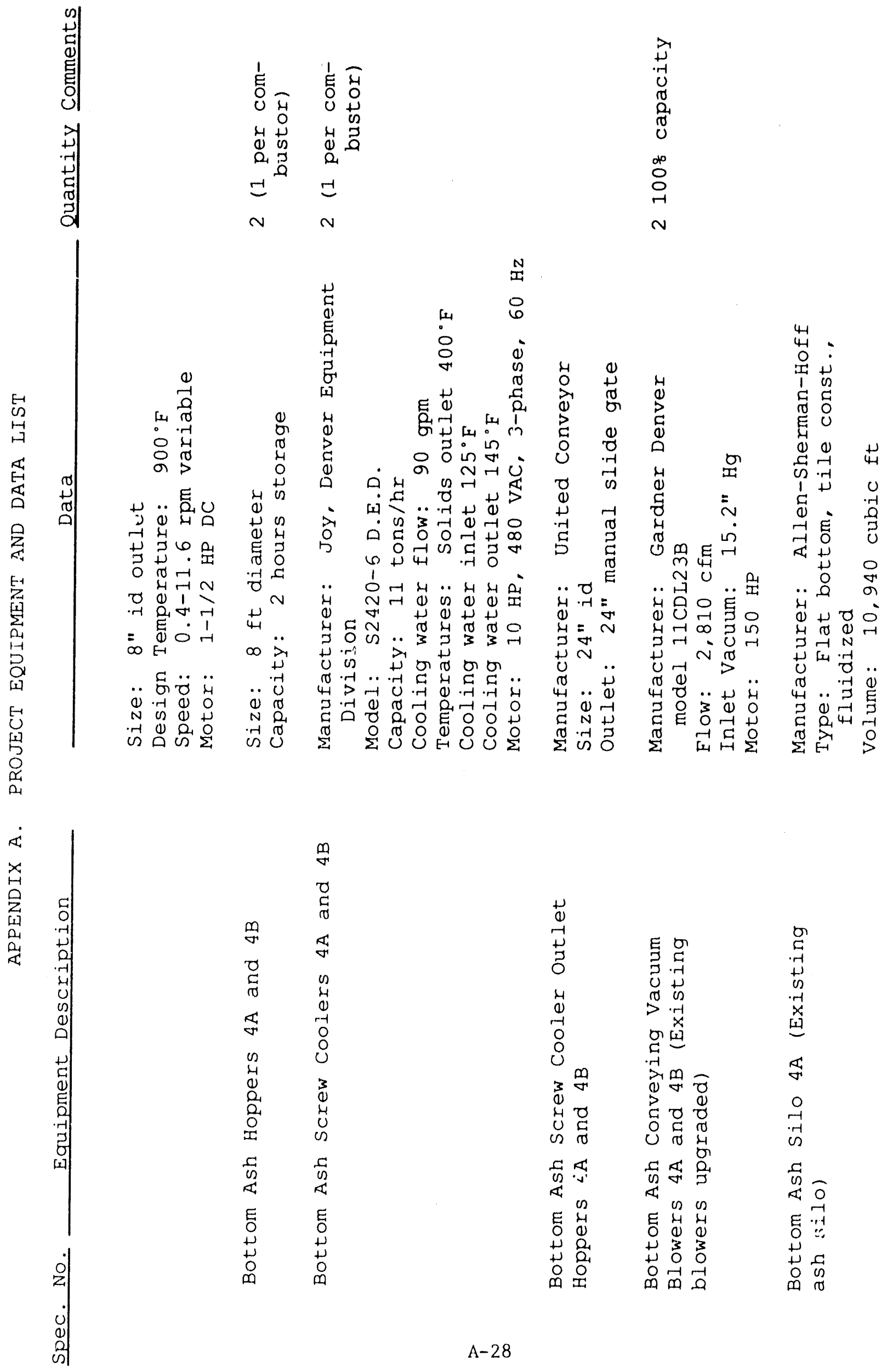


ज

式
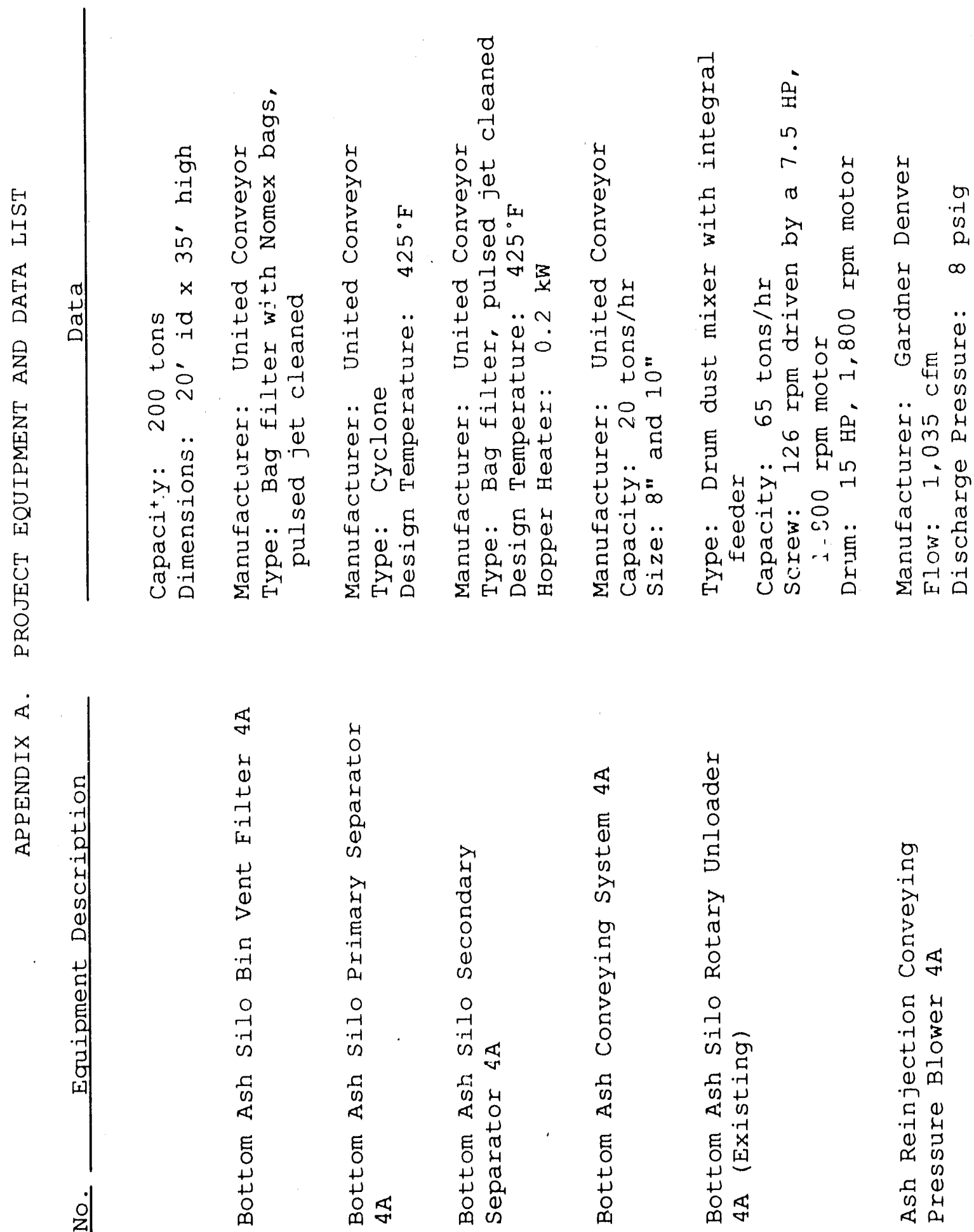


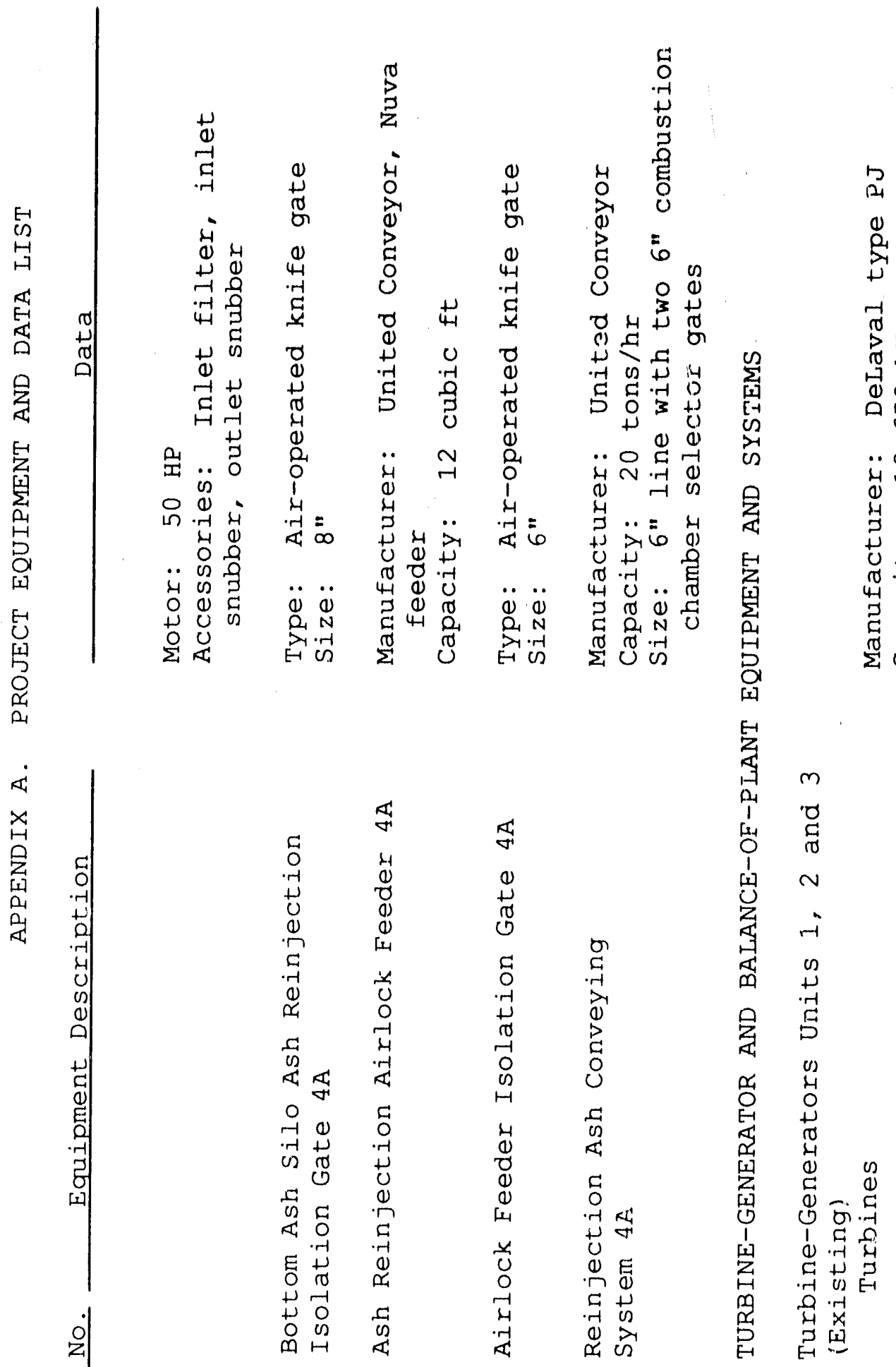




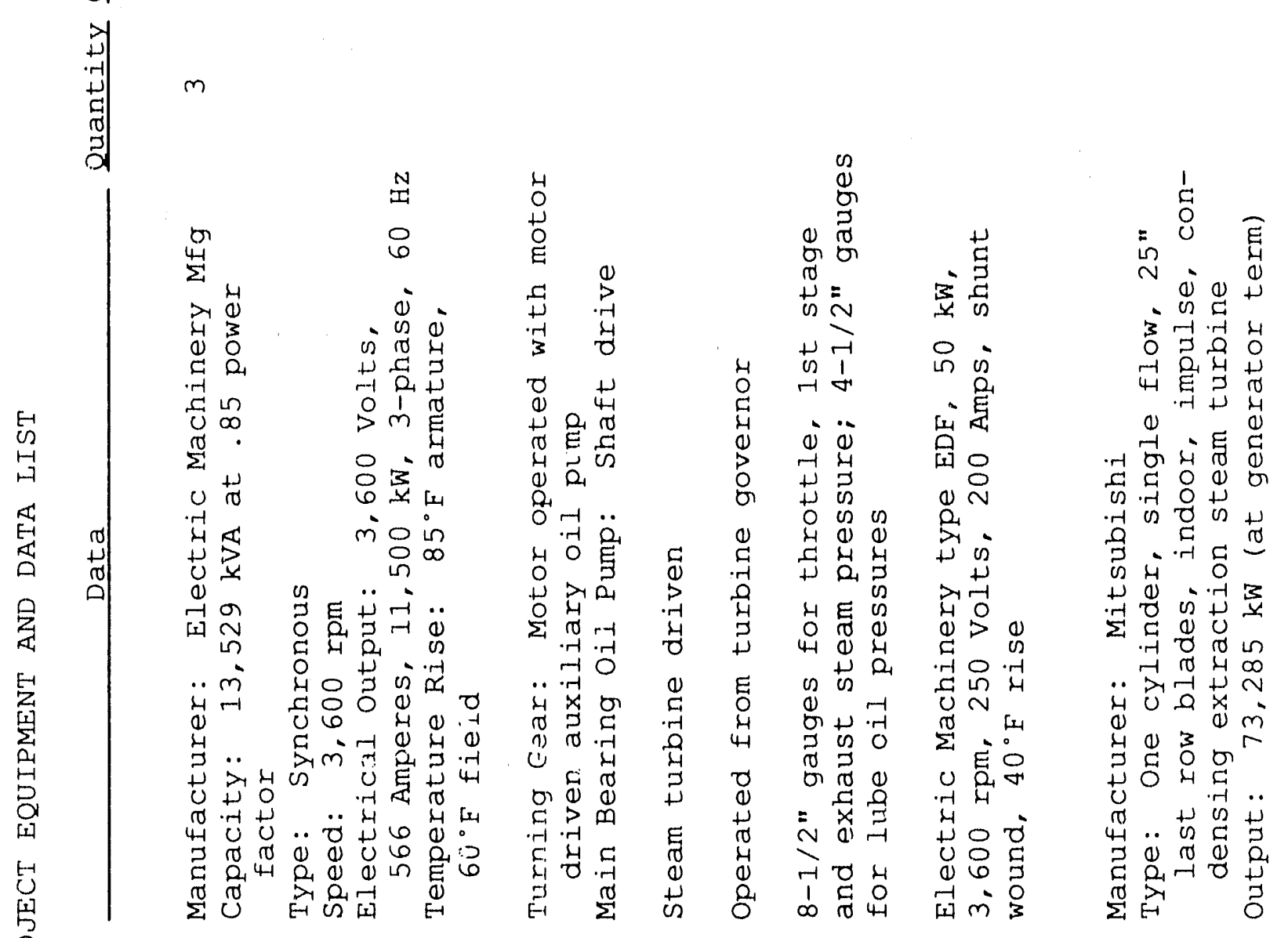

足
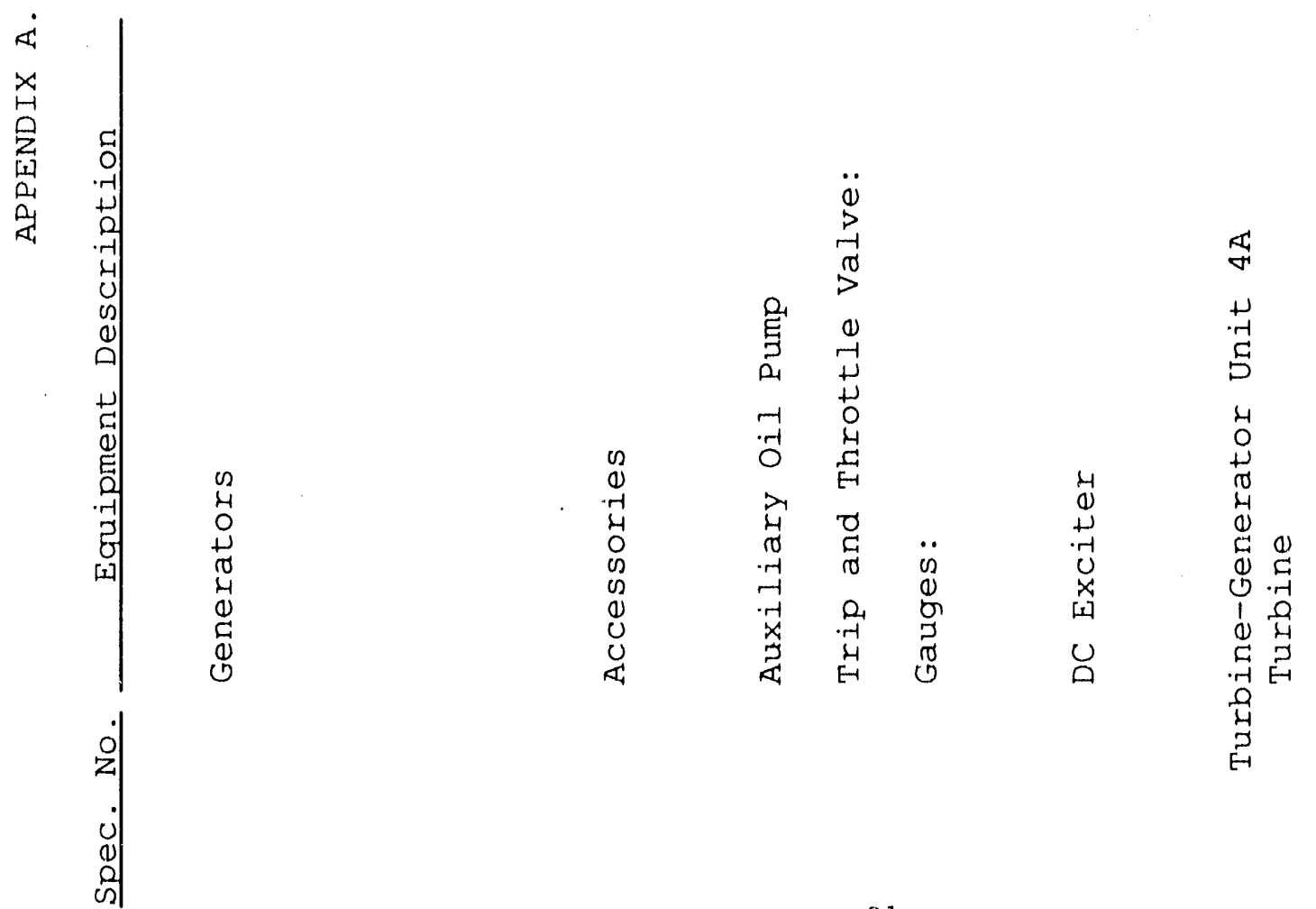
क्
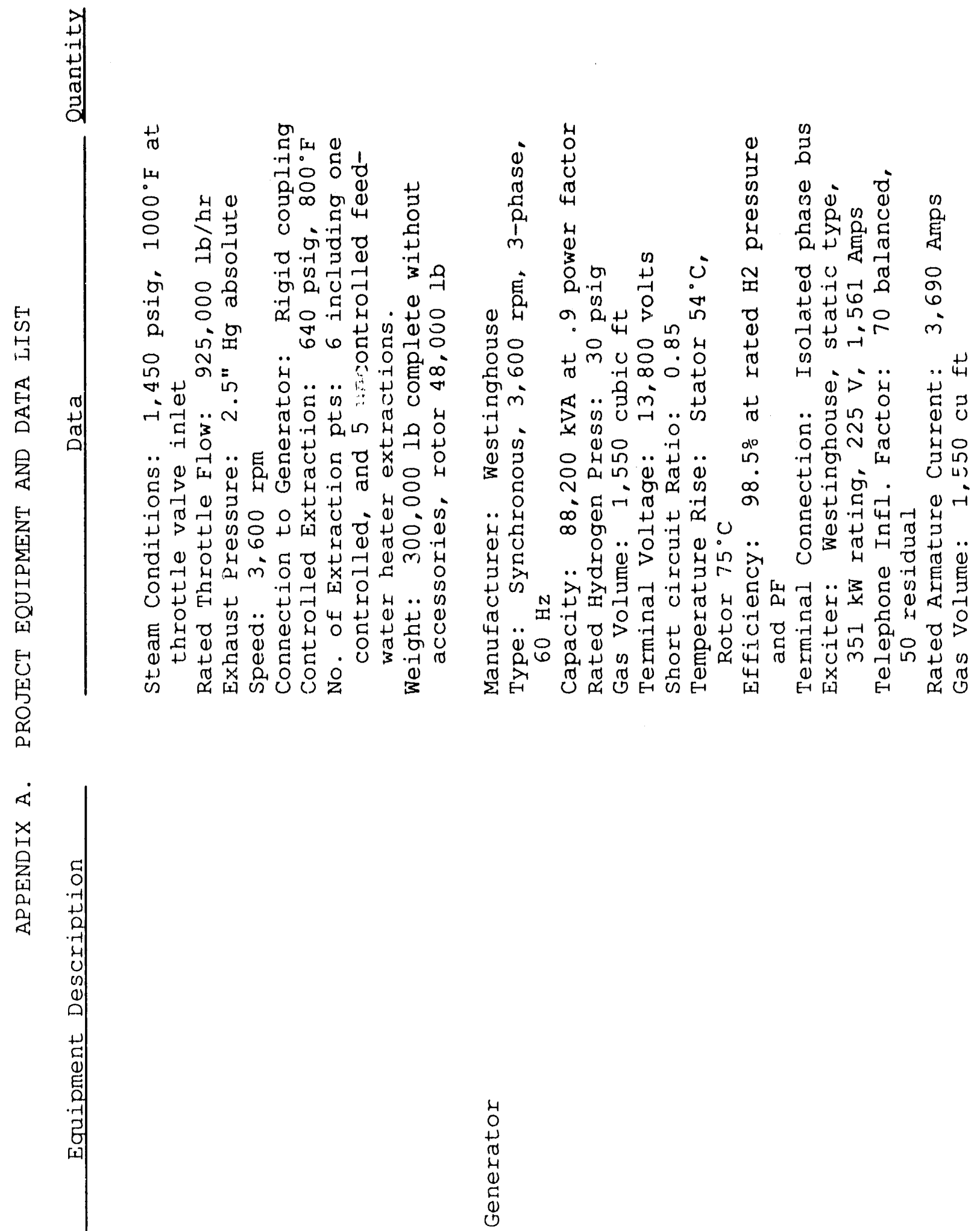


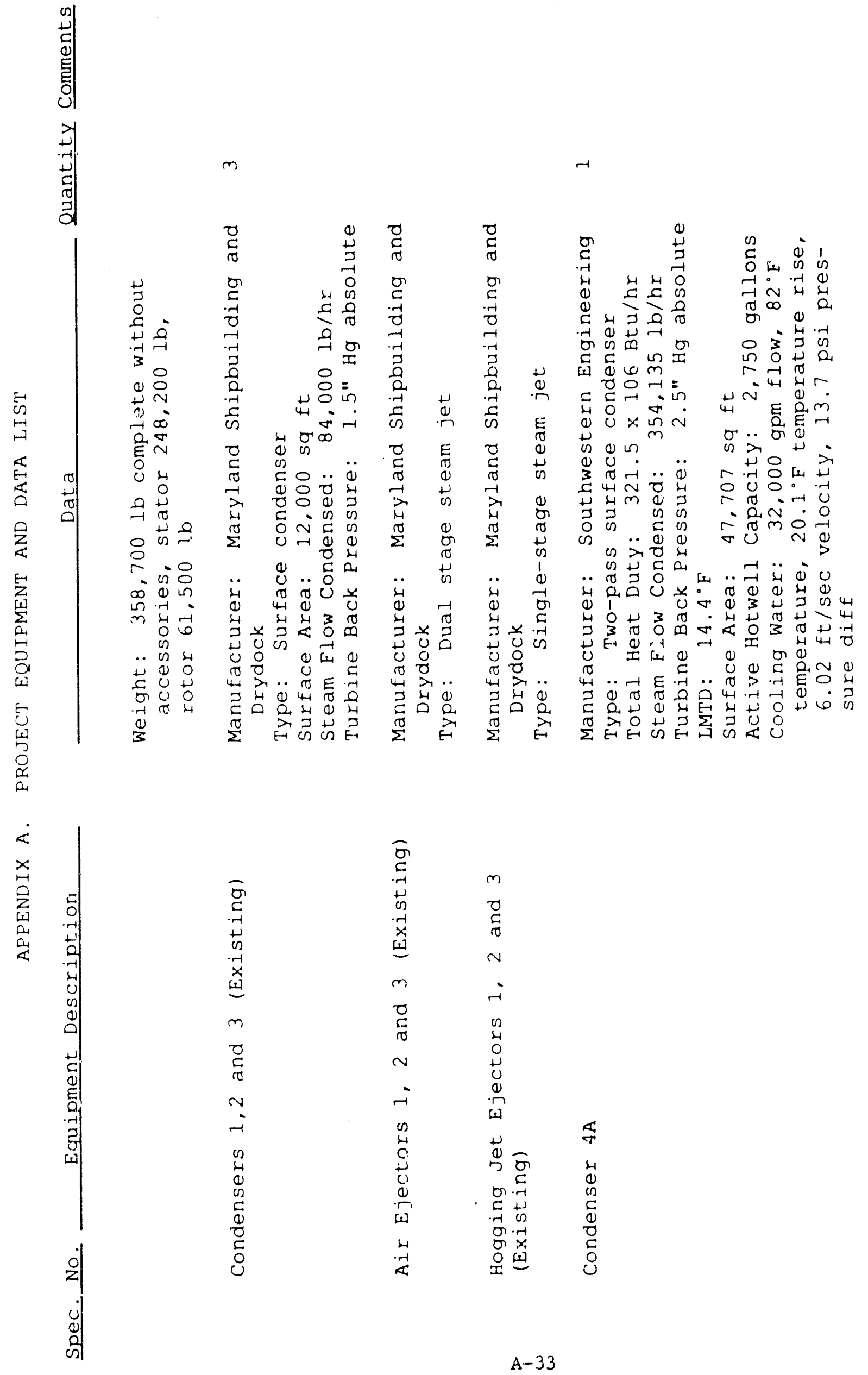




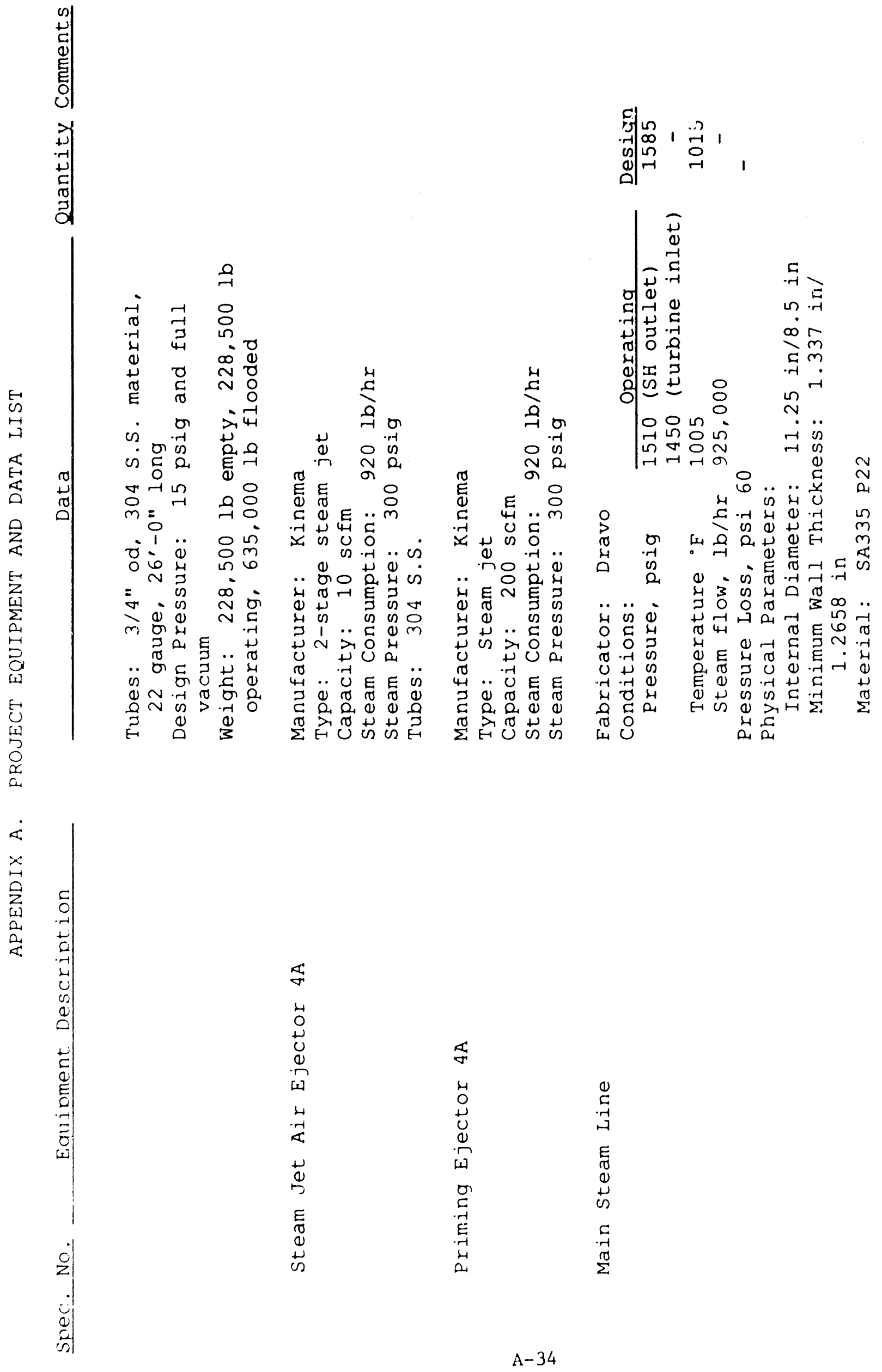




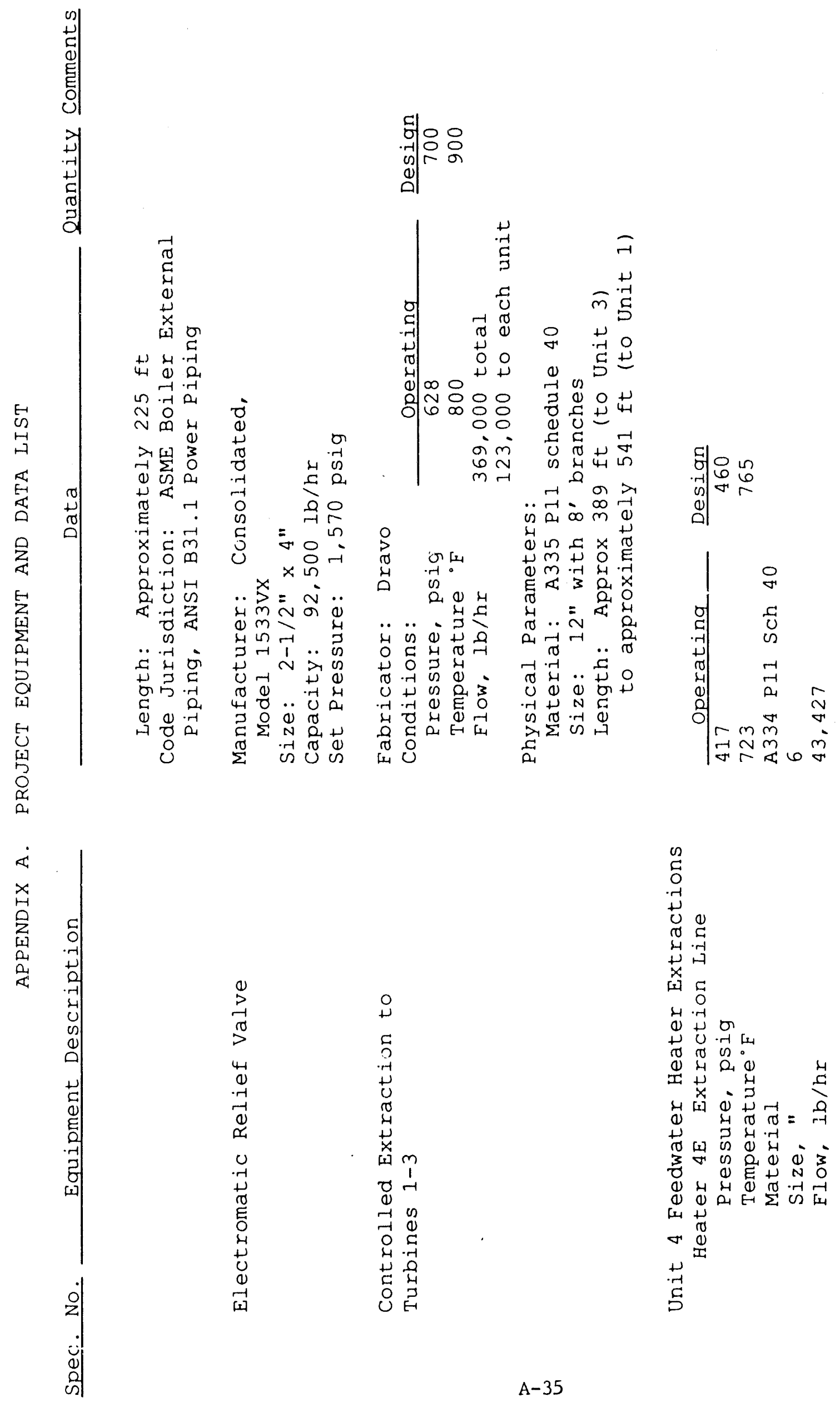




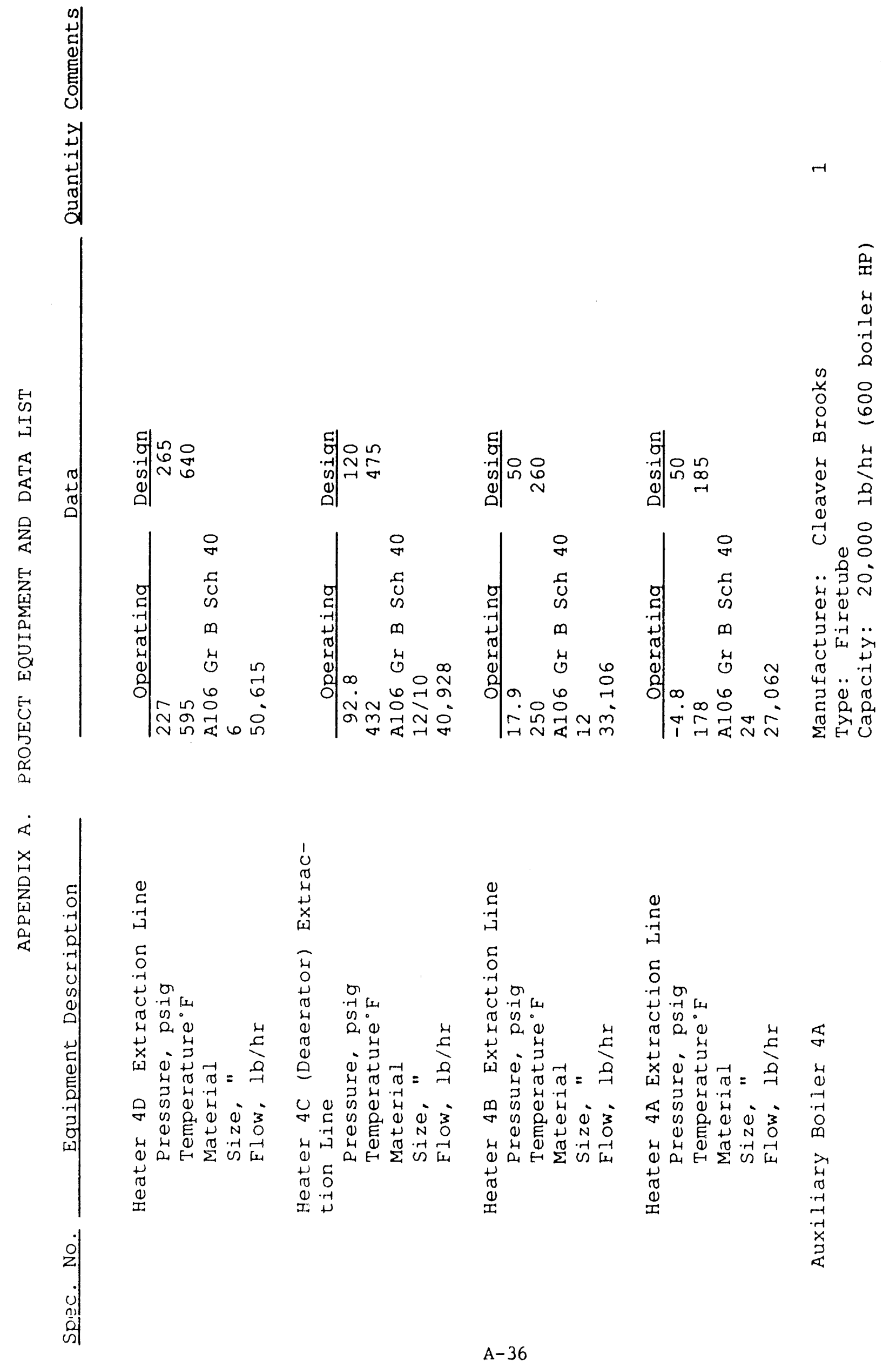




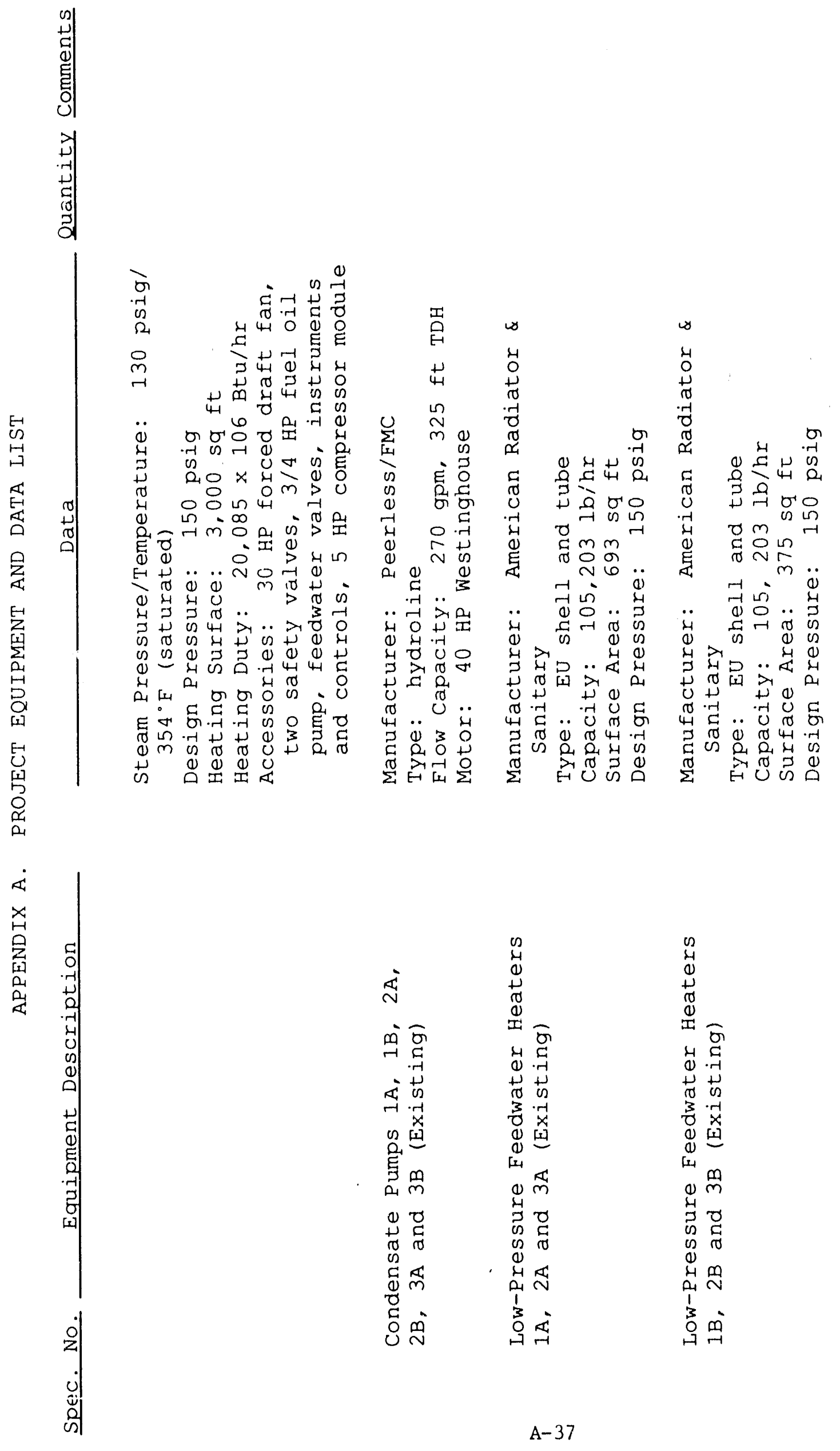




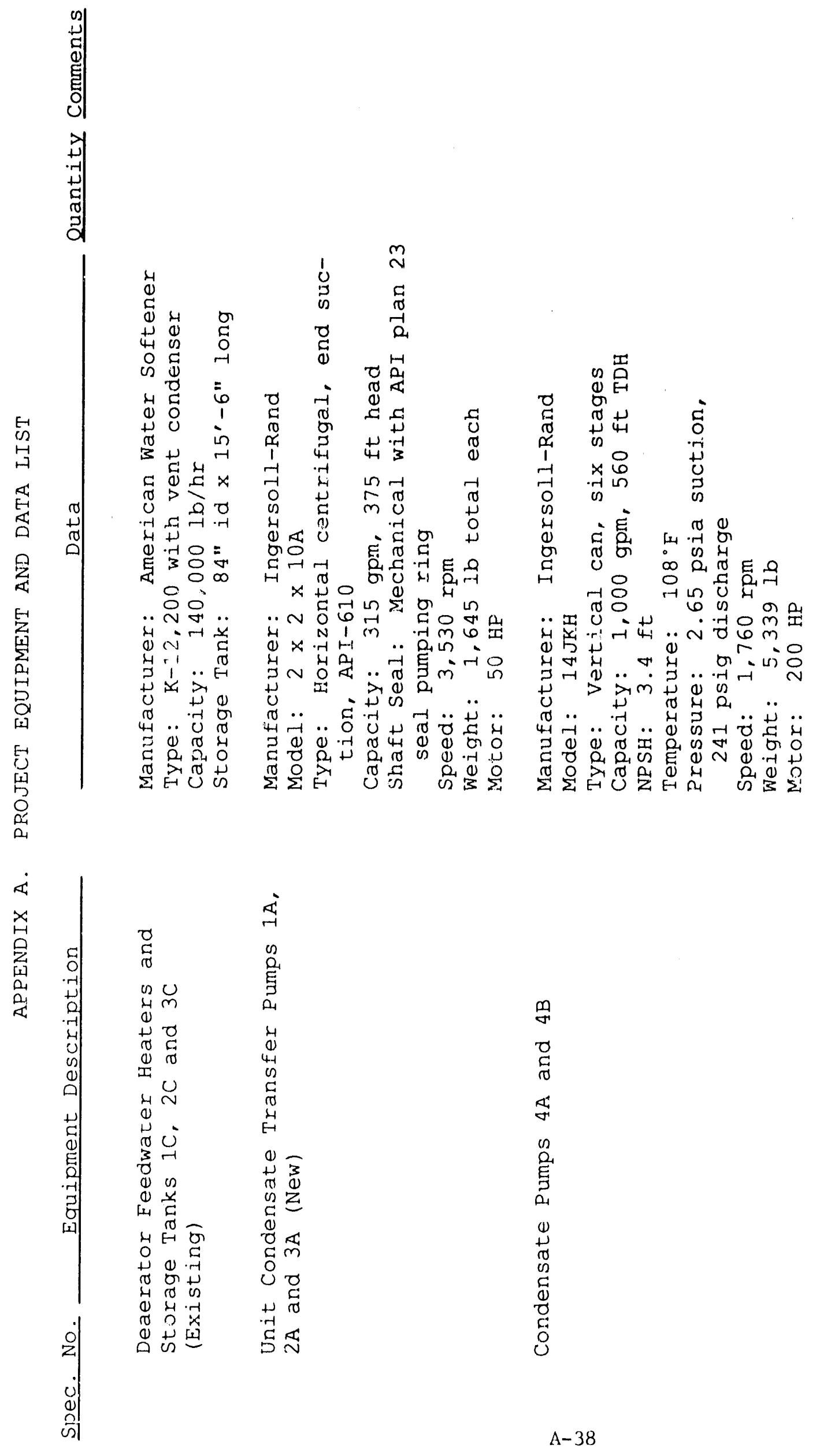



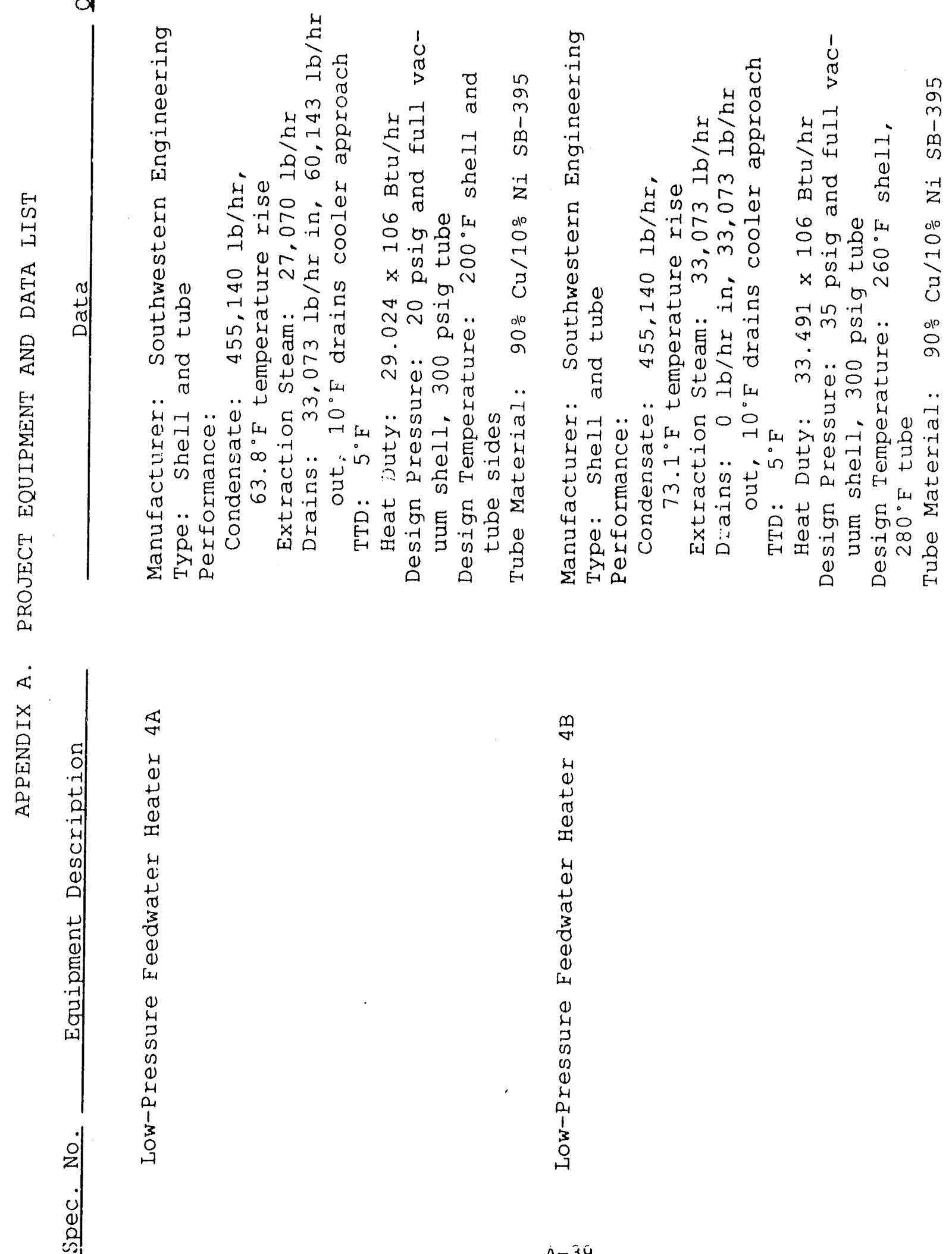

荈

4
0
1
0
0
0
4
4
0
0
0
0
0
0
0
0
0
0

0
0
4
2
0
0
0
0
0
01
1
3
0
0
5 


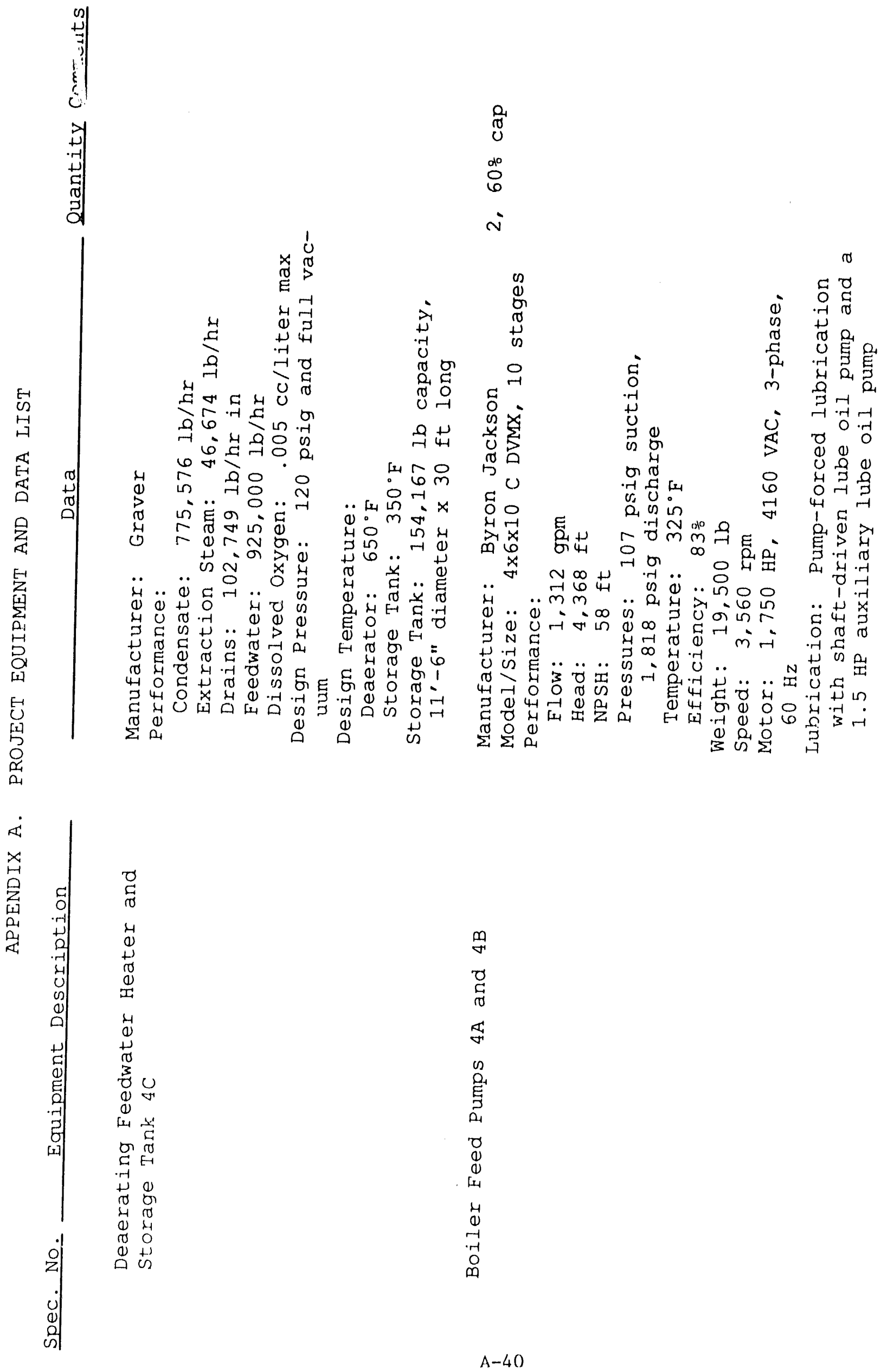


क्
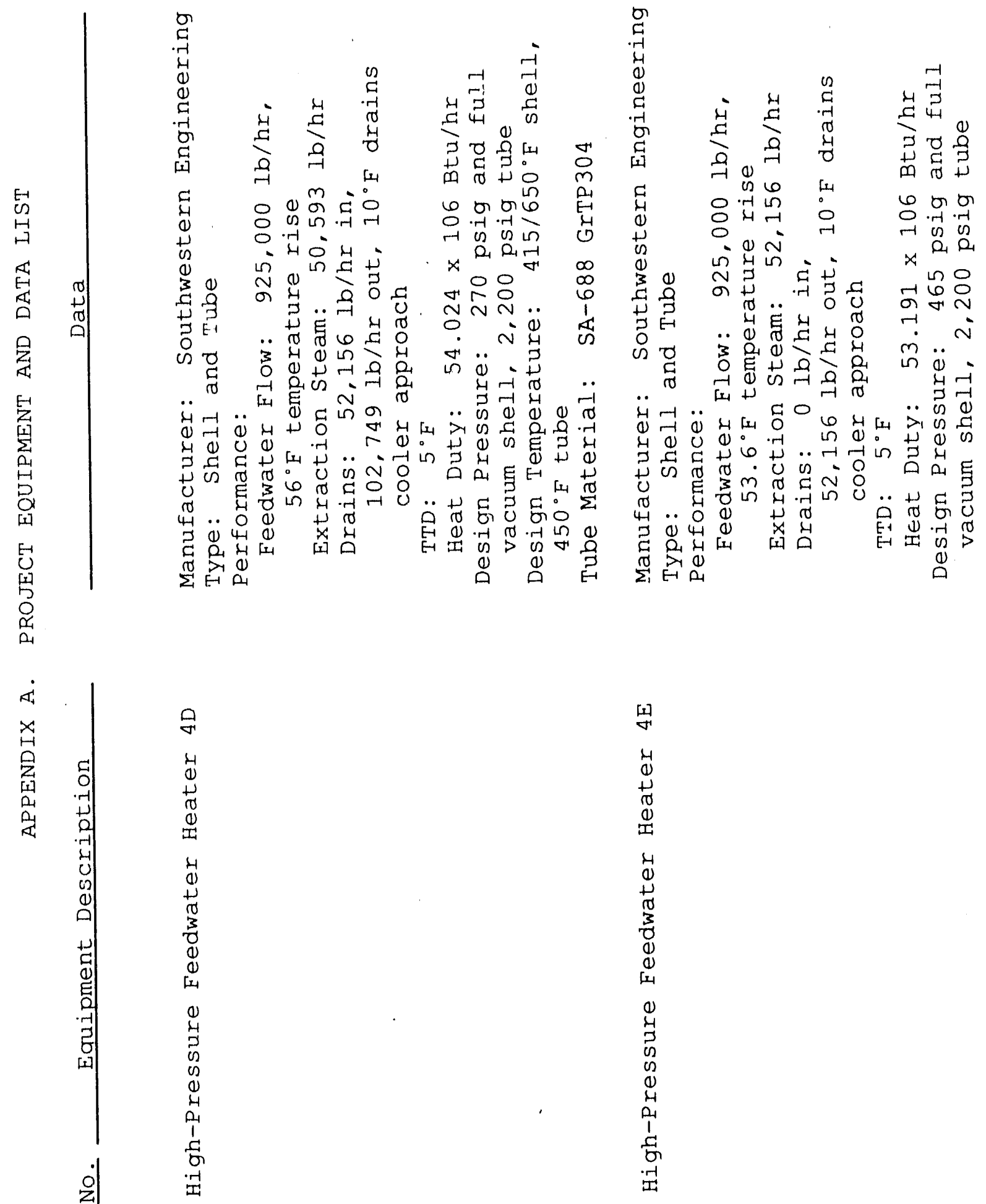


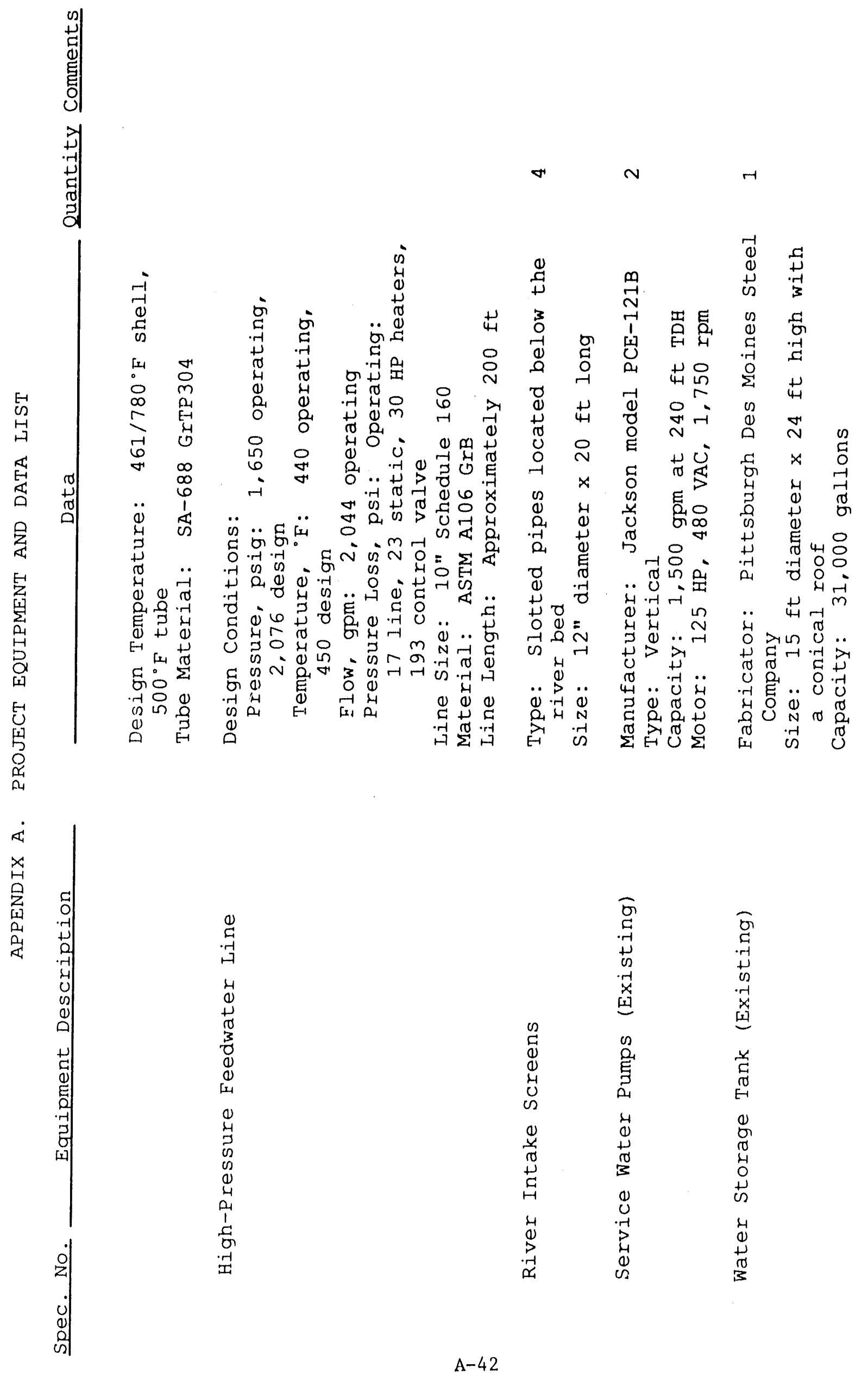


号

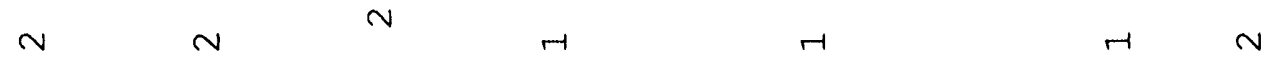

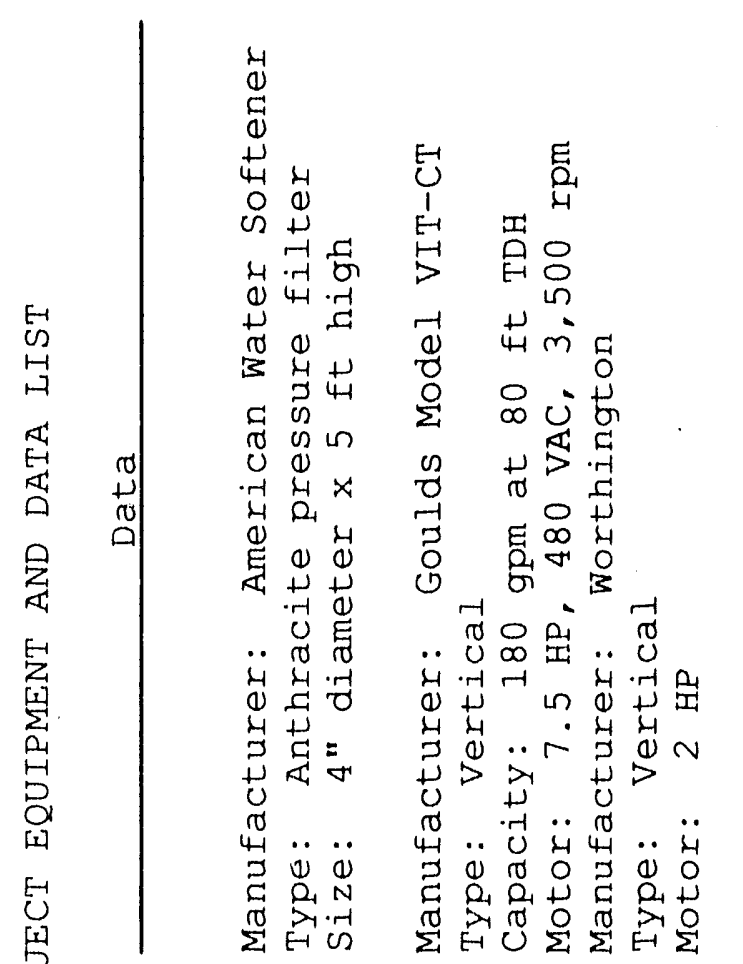

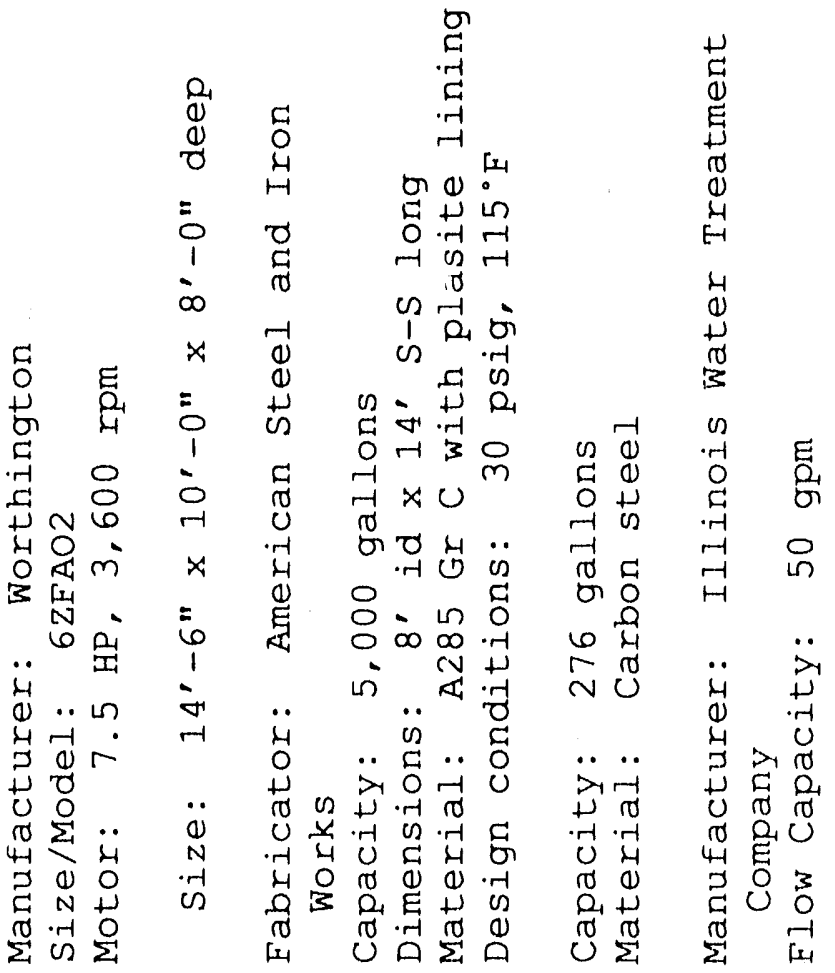

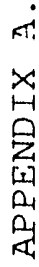

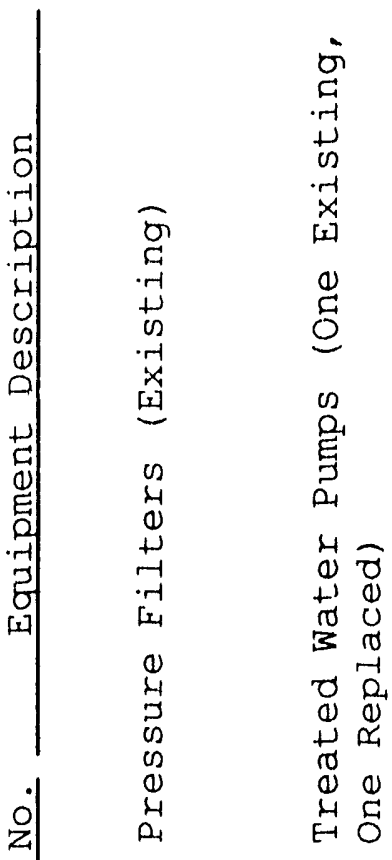

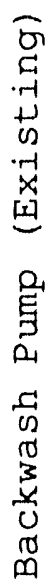

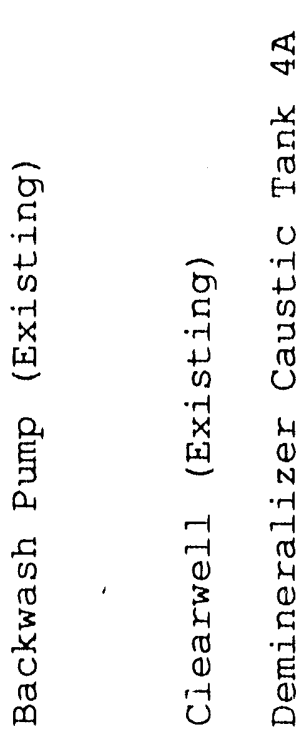

算

总集

永

व

岱

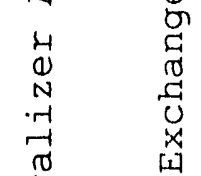

(1)

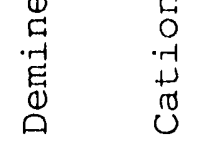




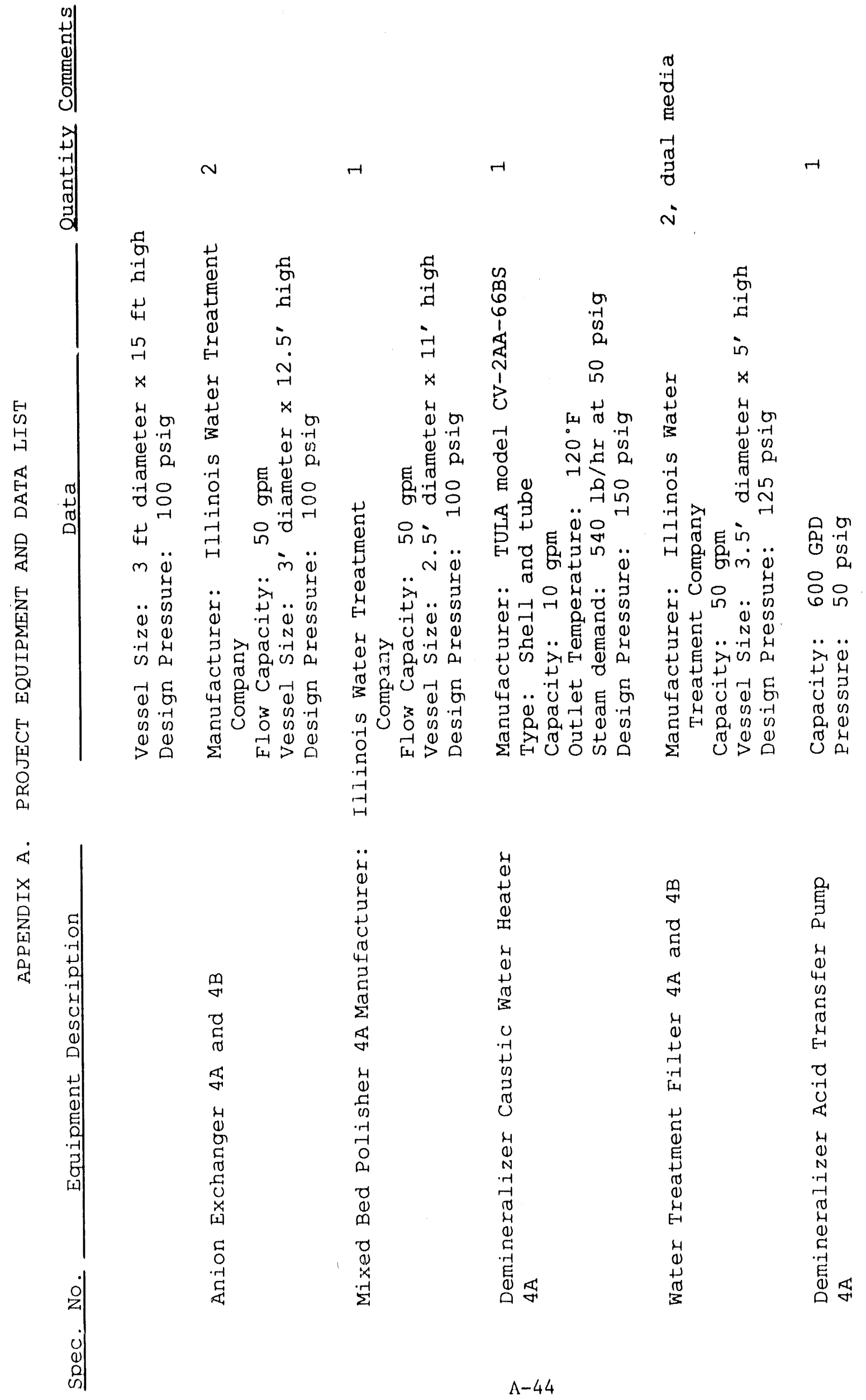




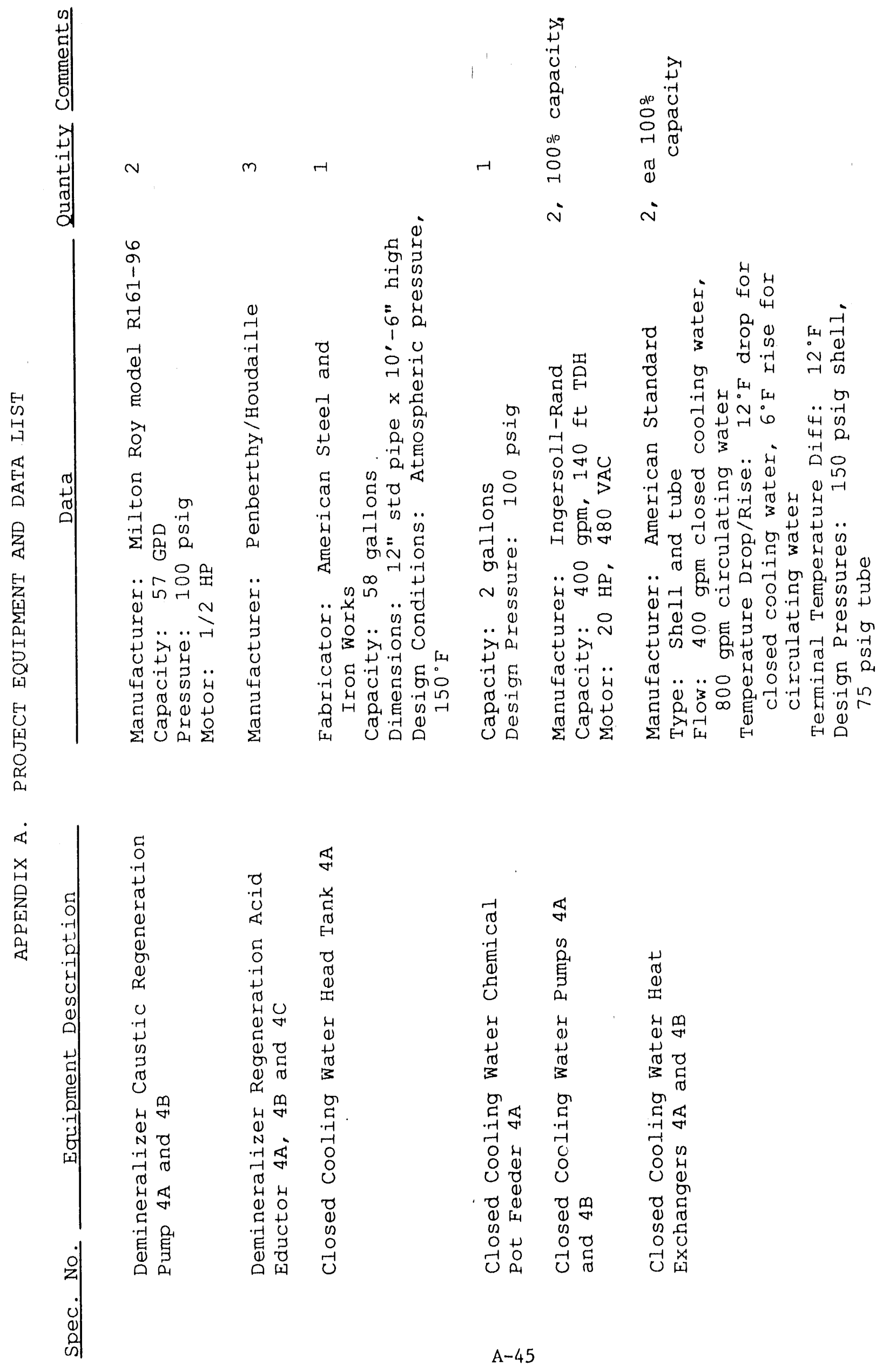




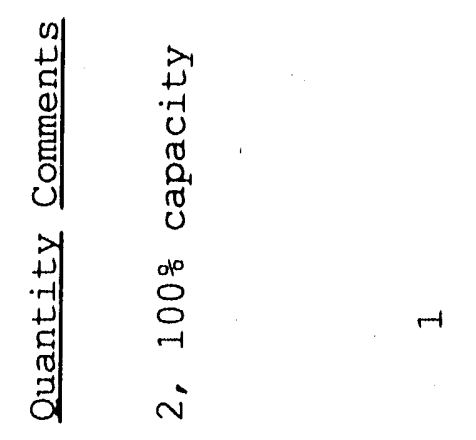

$m$
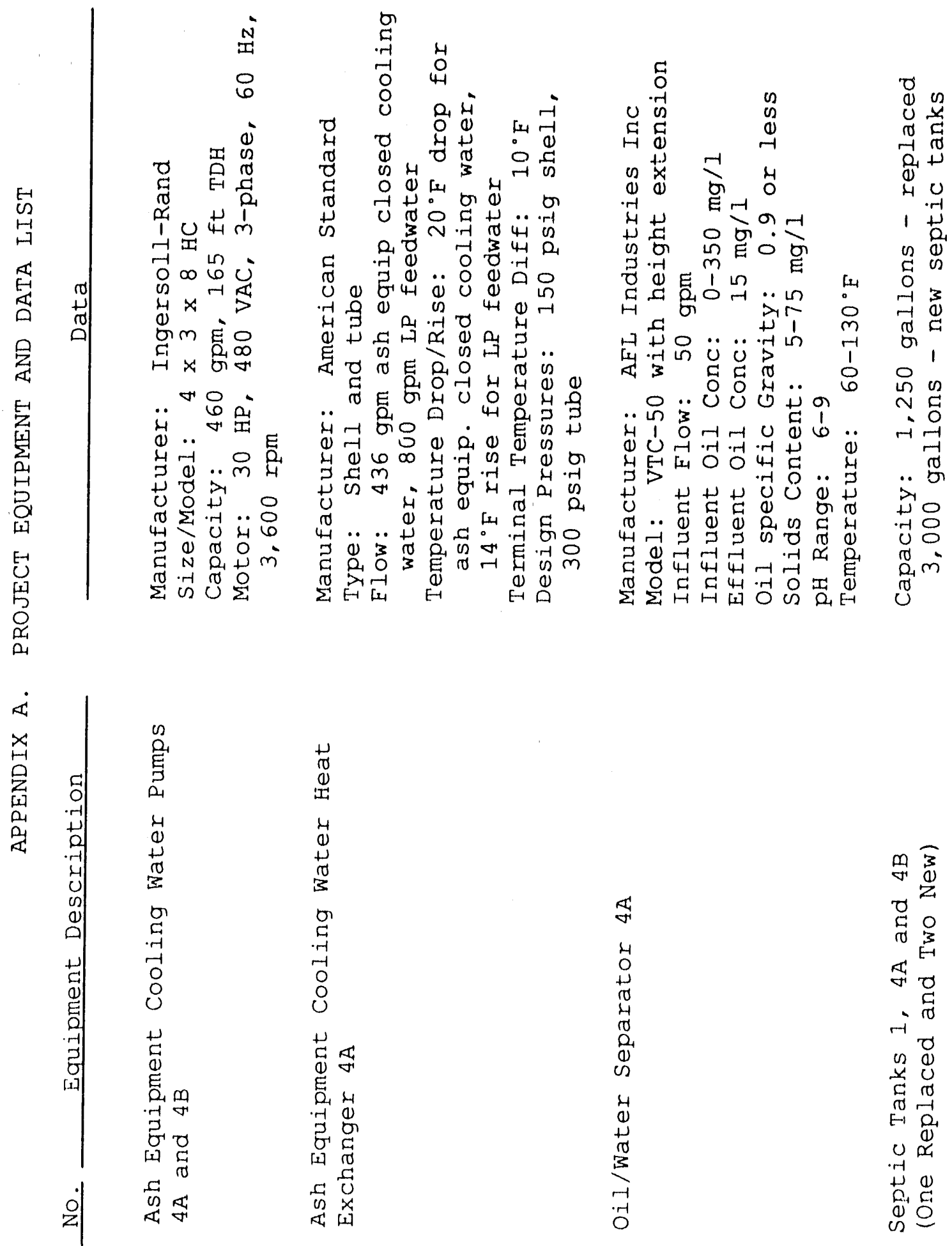


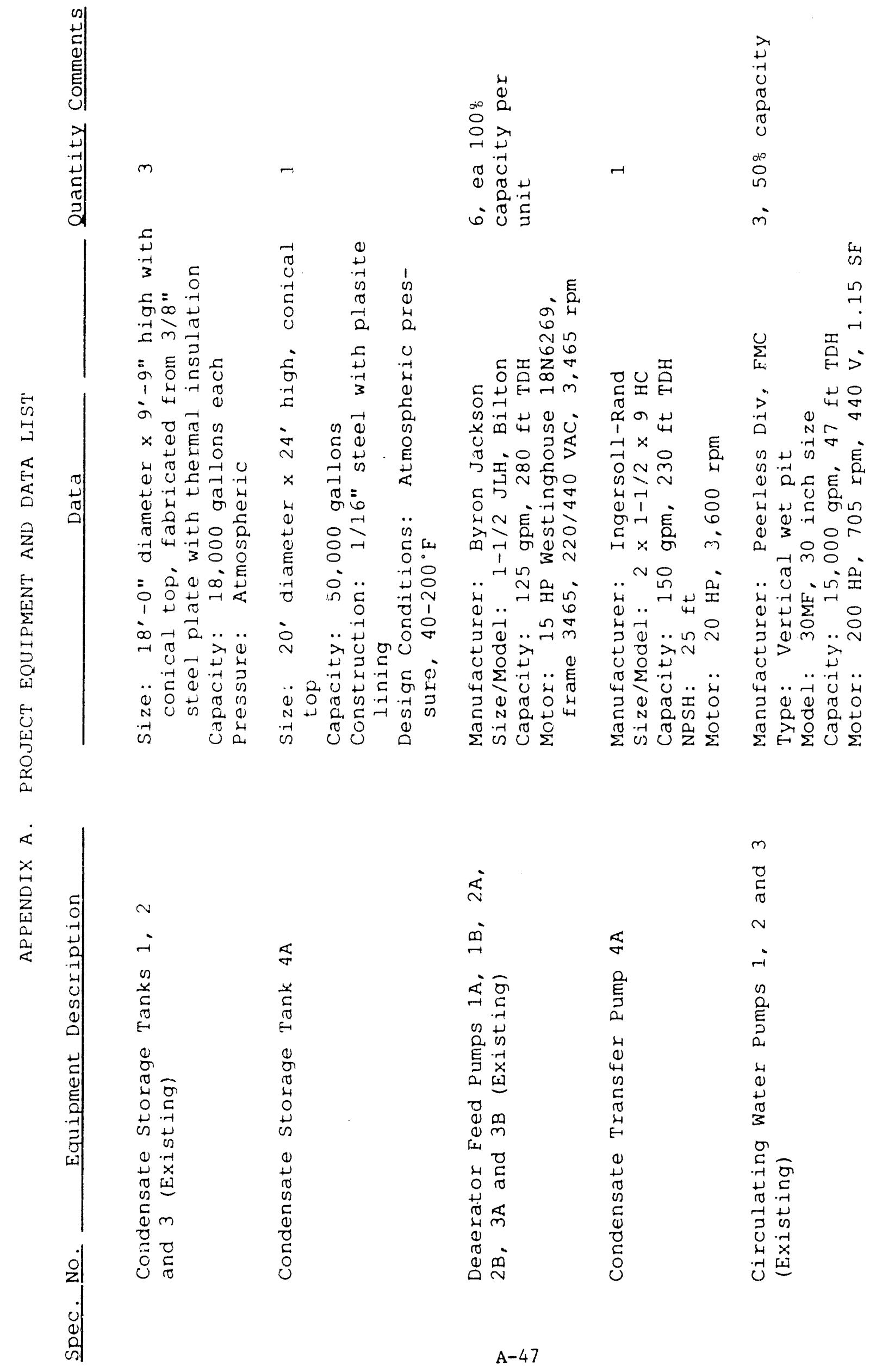




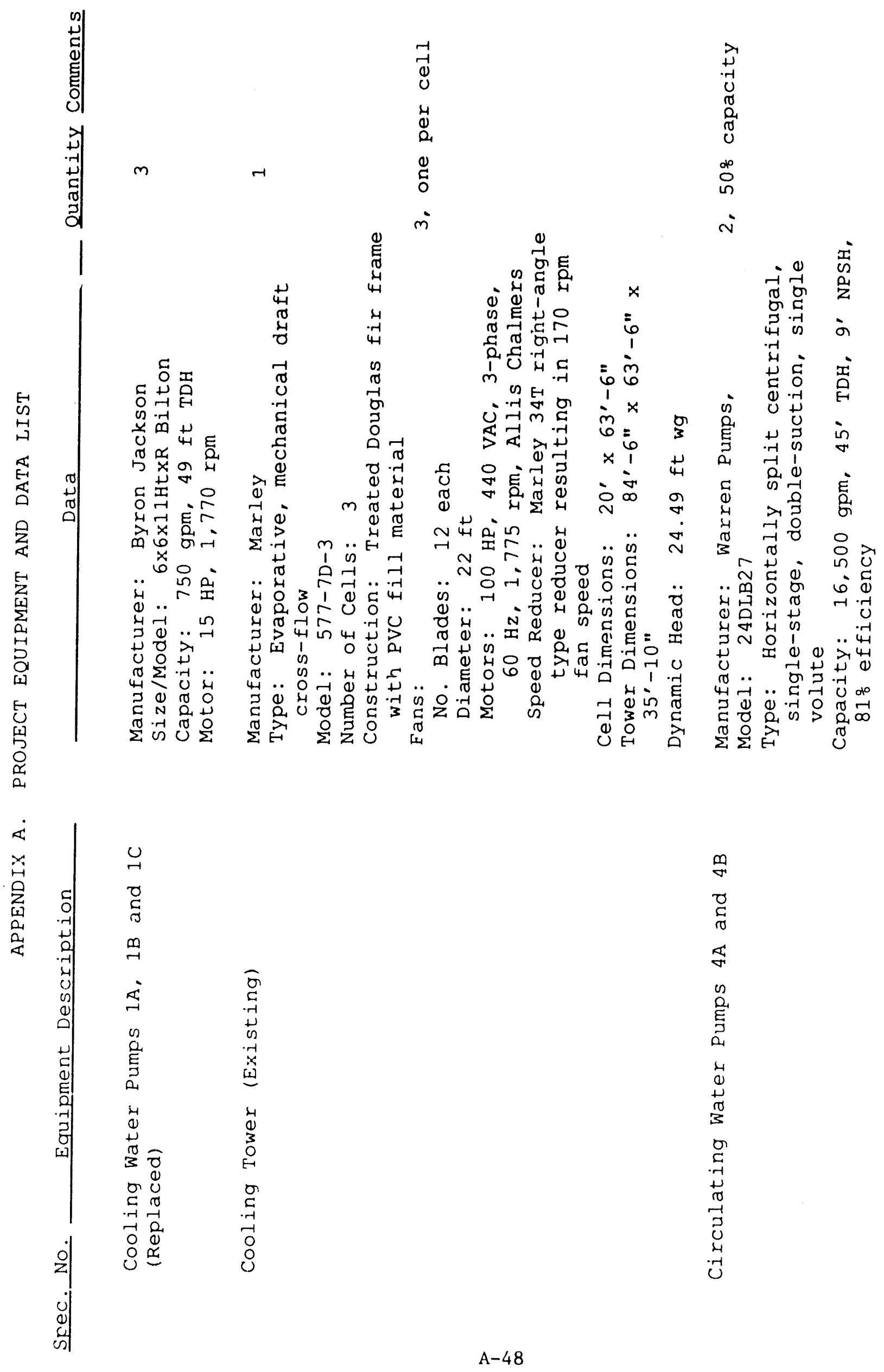




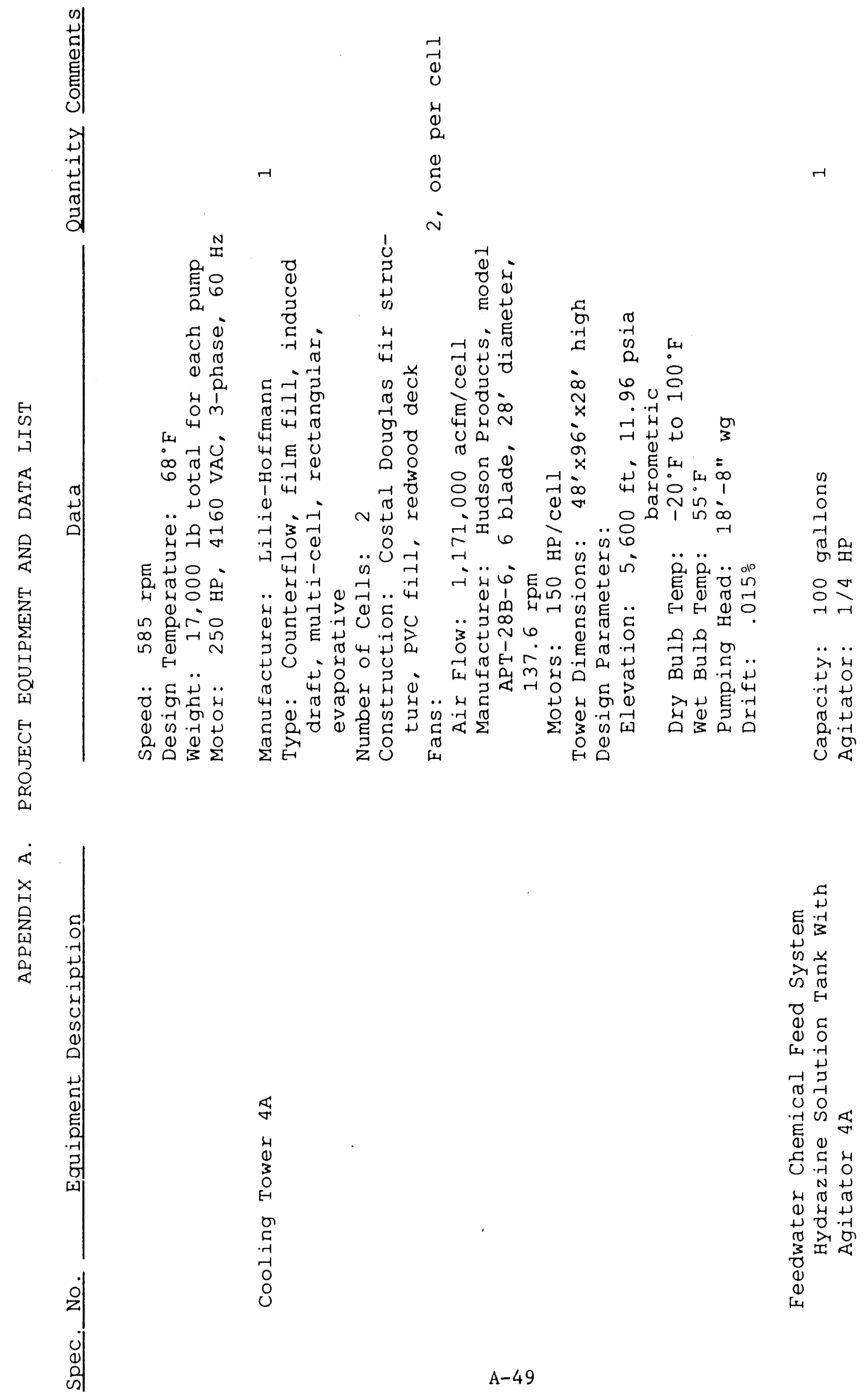


員

式

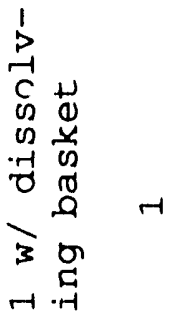

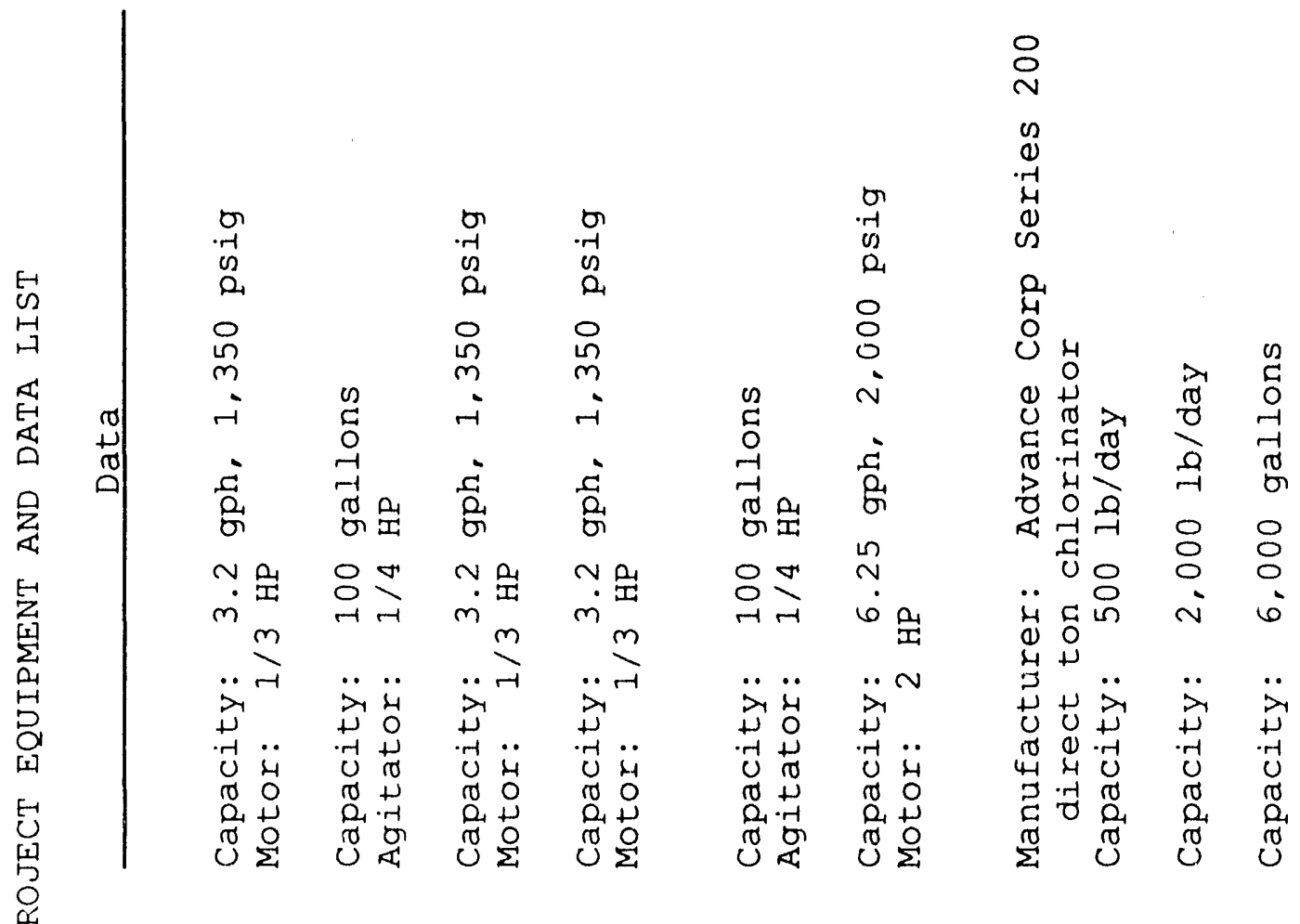

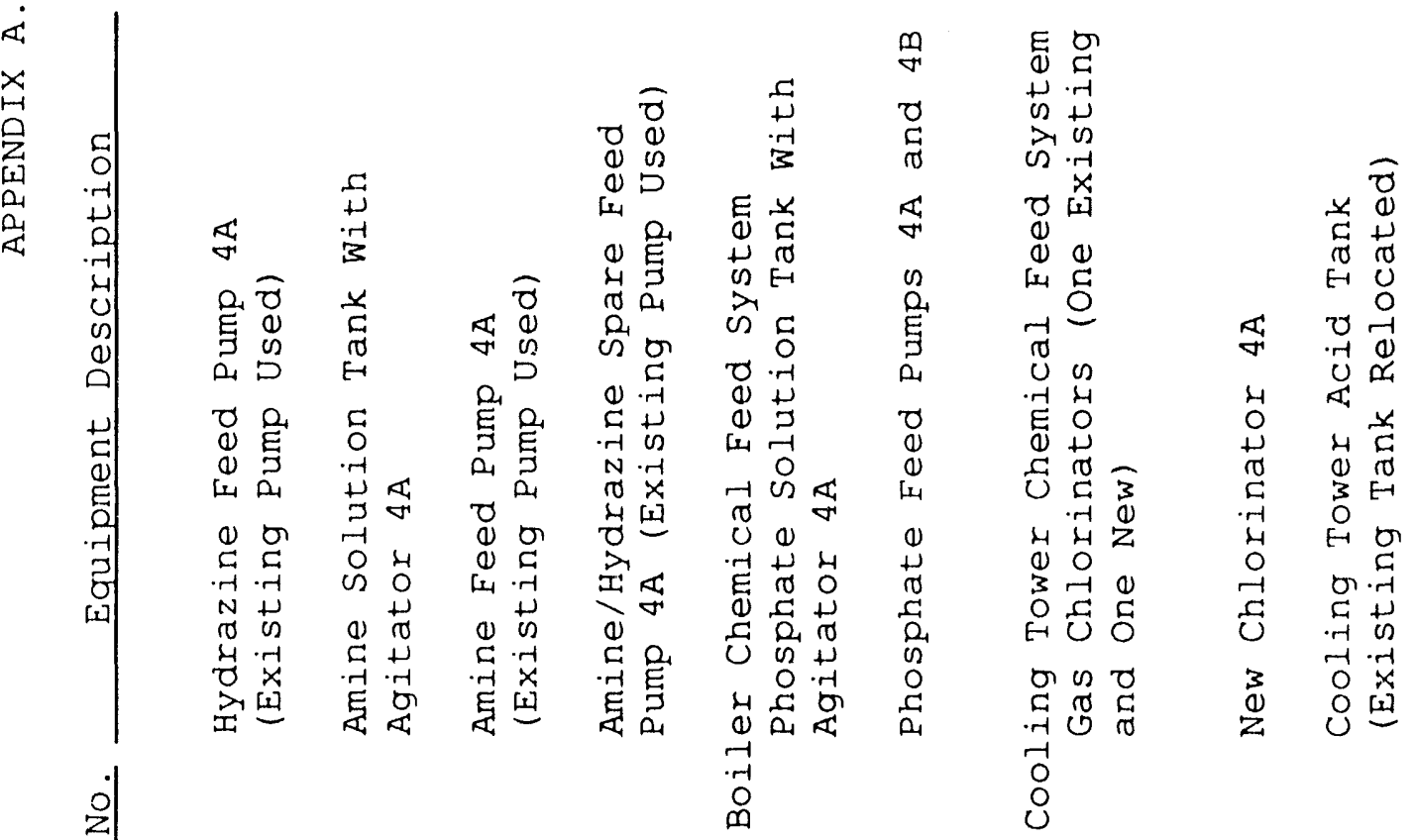




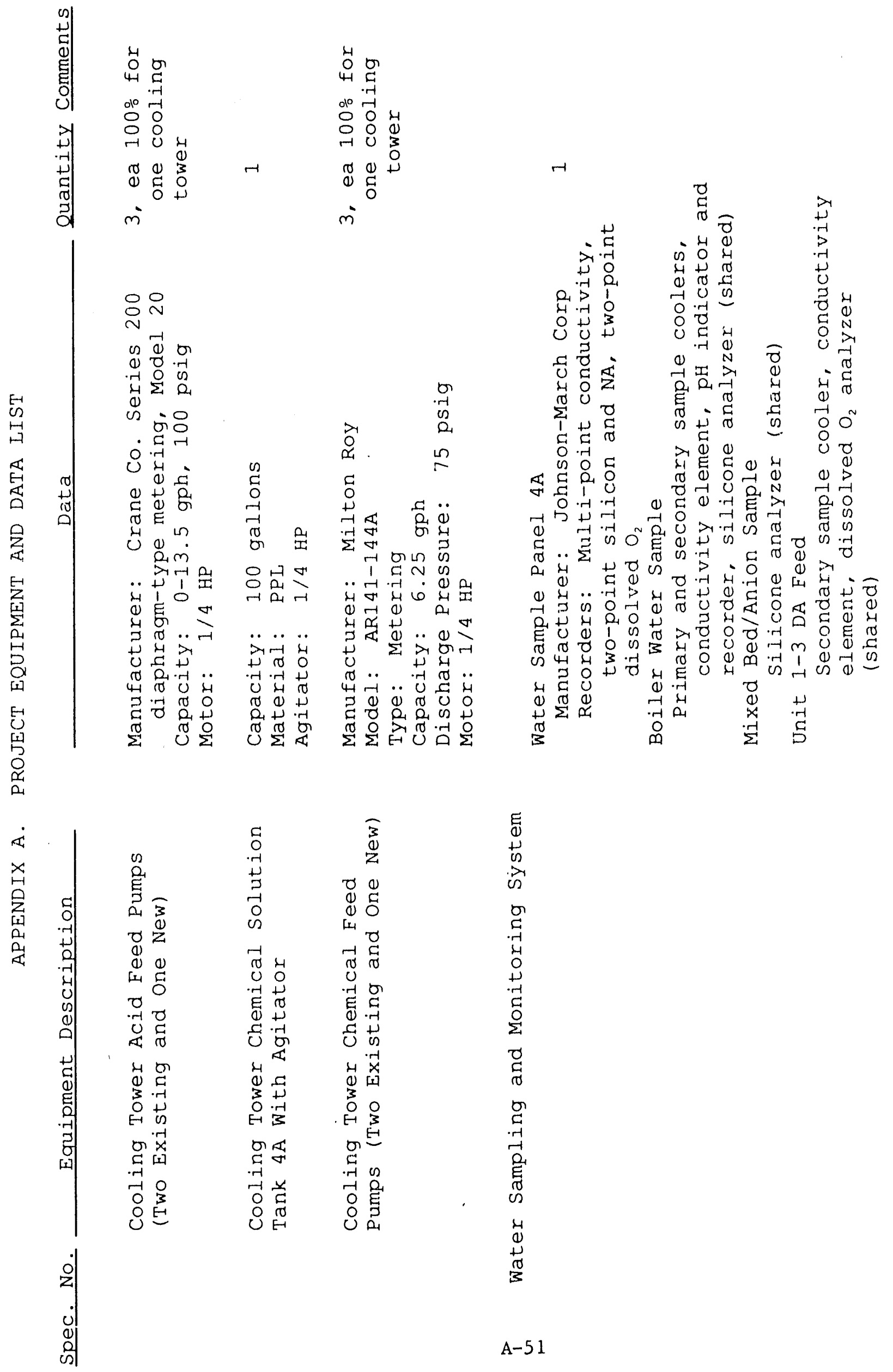




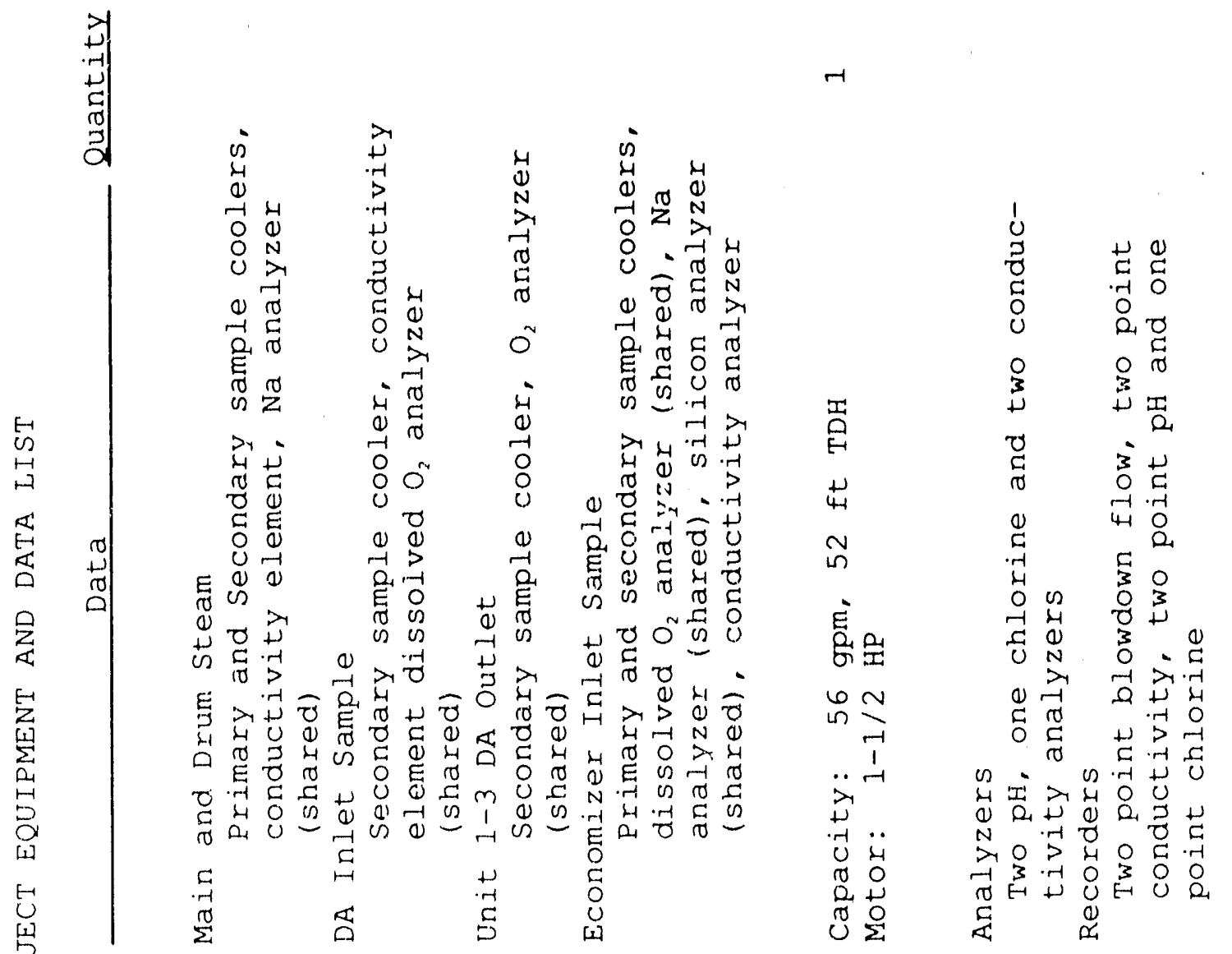

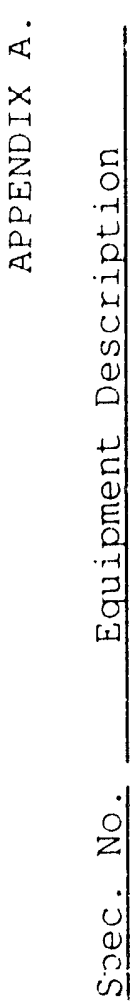

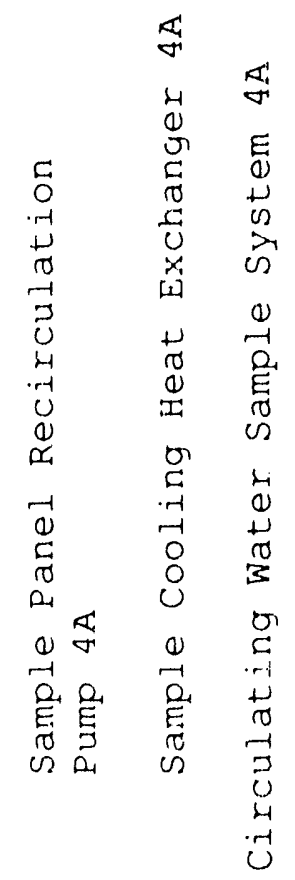




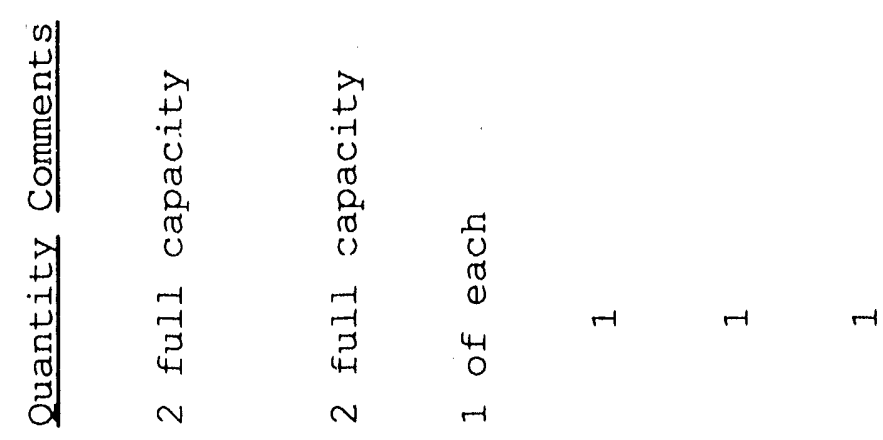

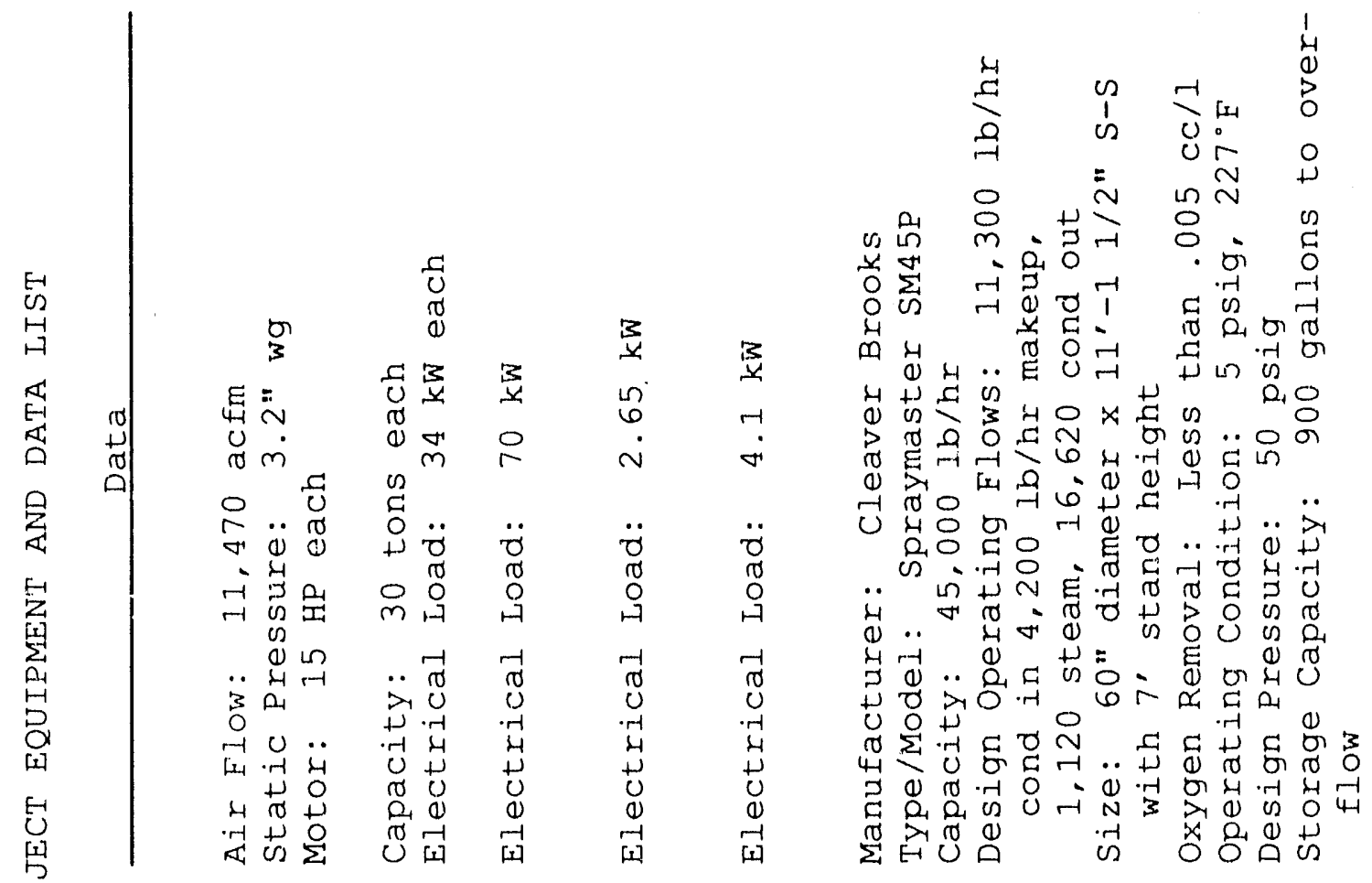

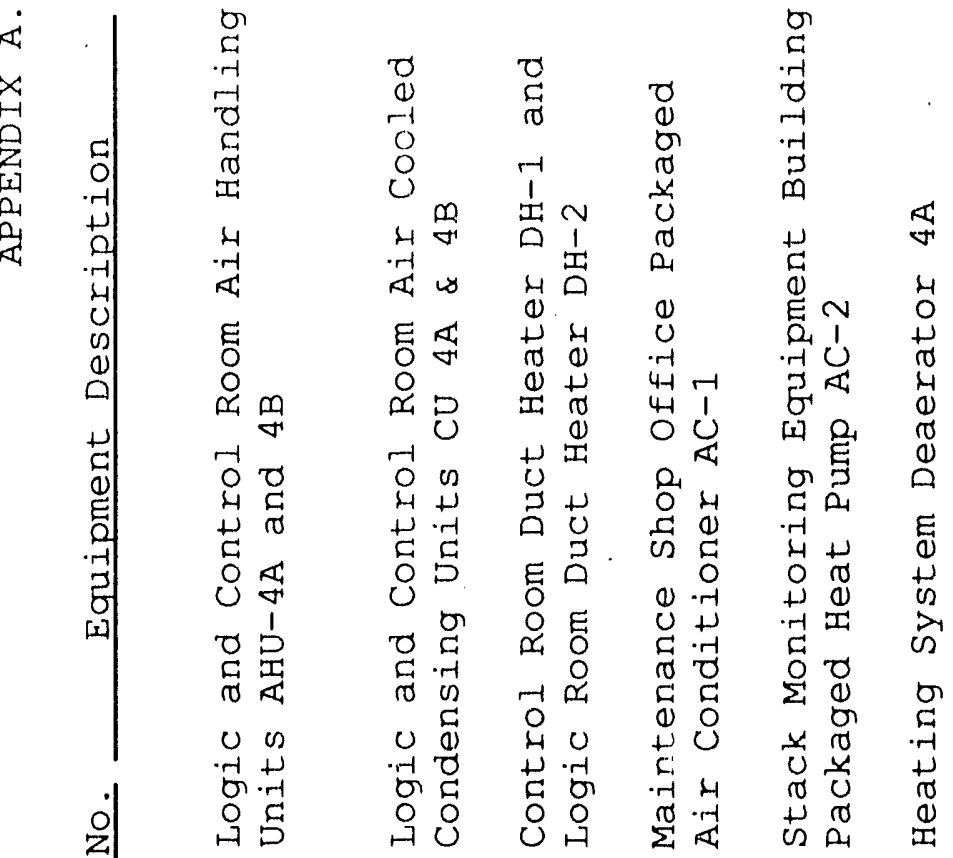




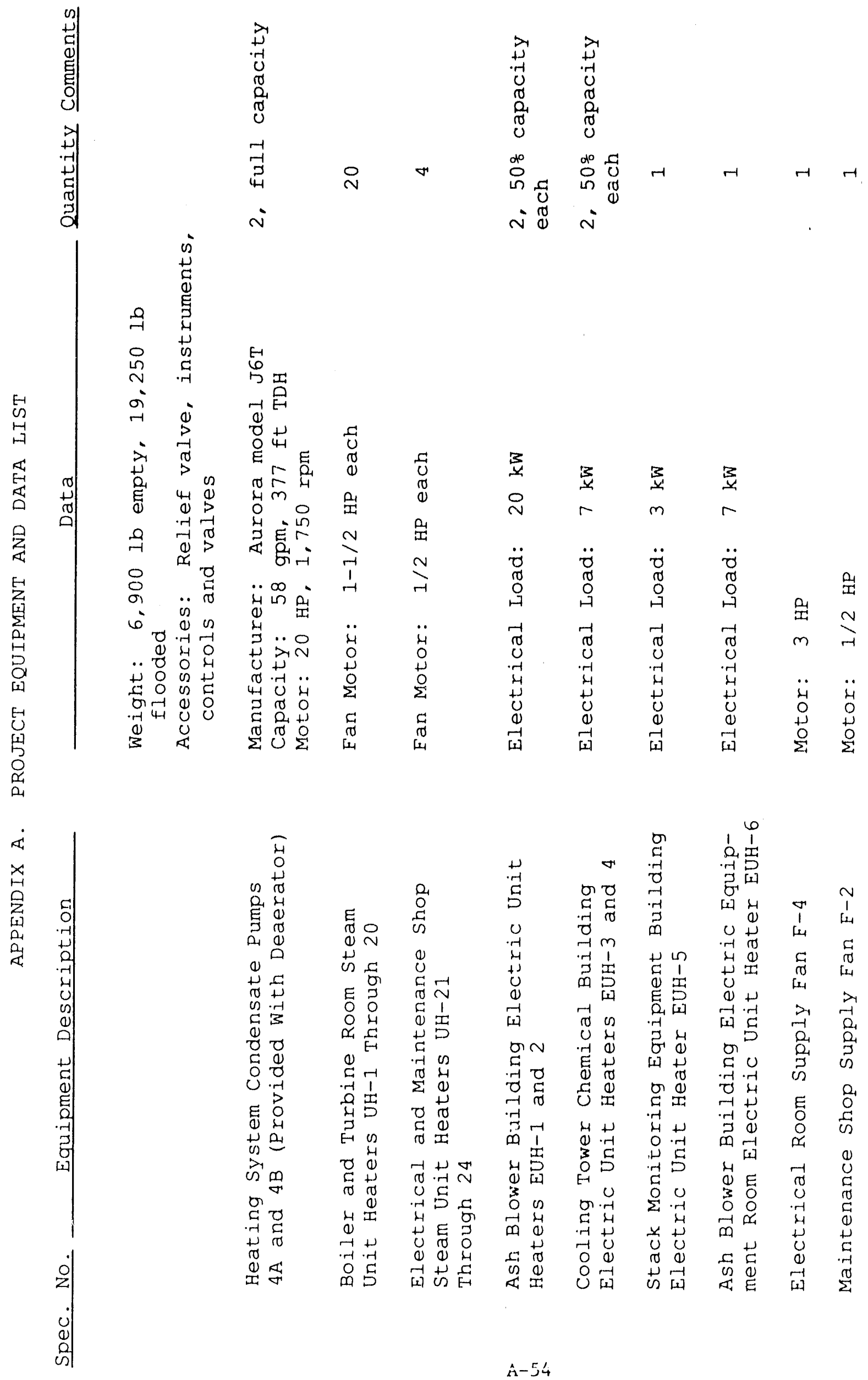




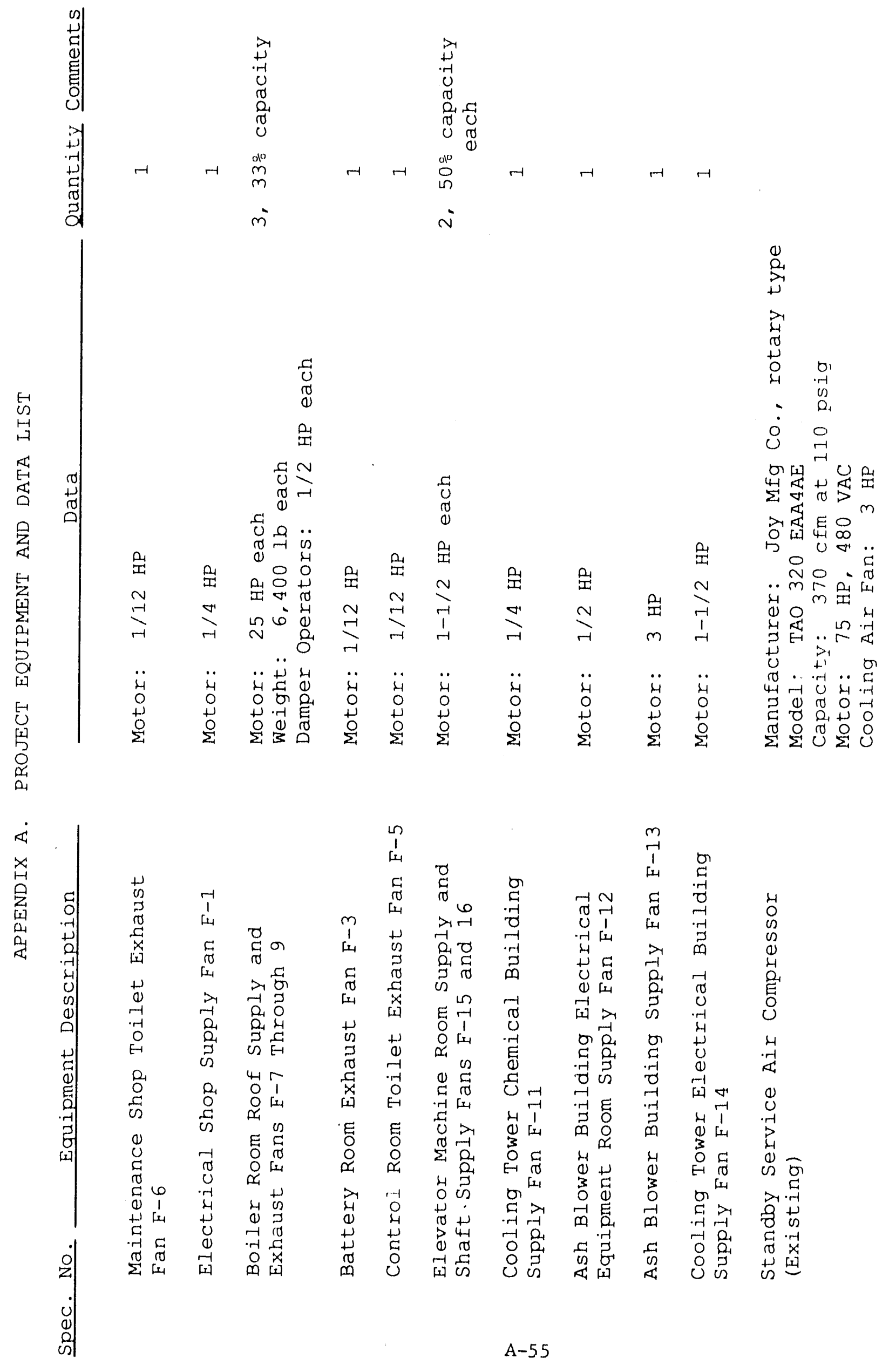




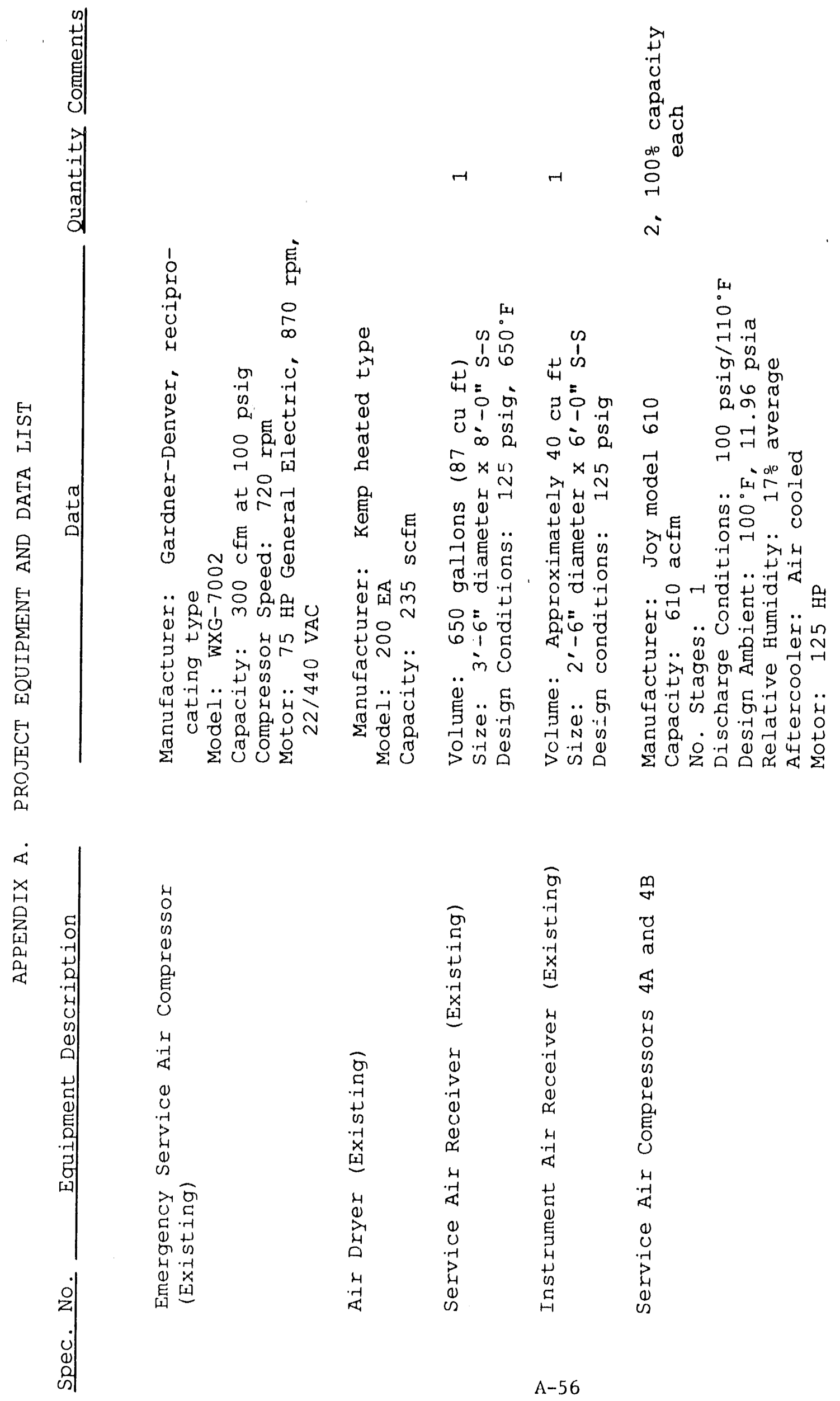




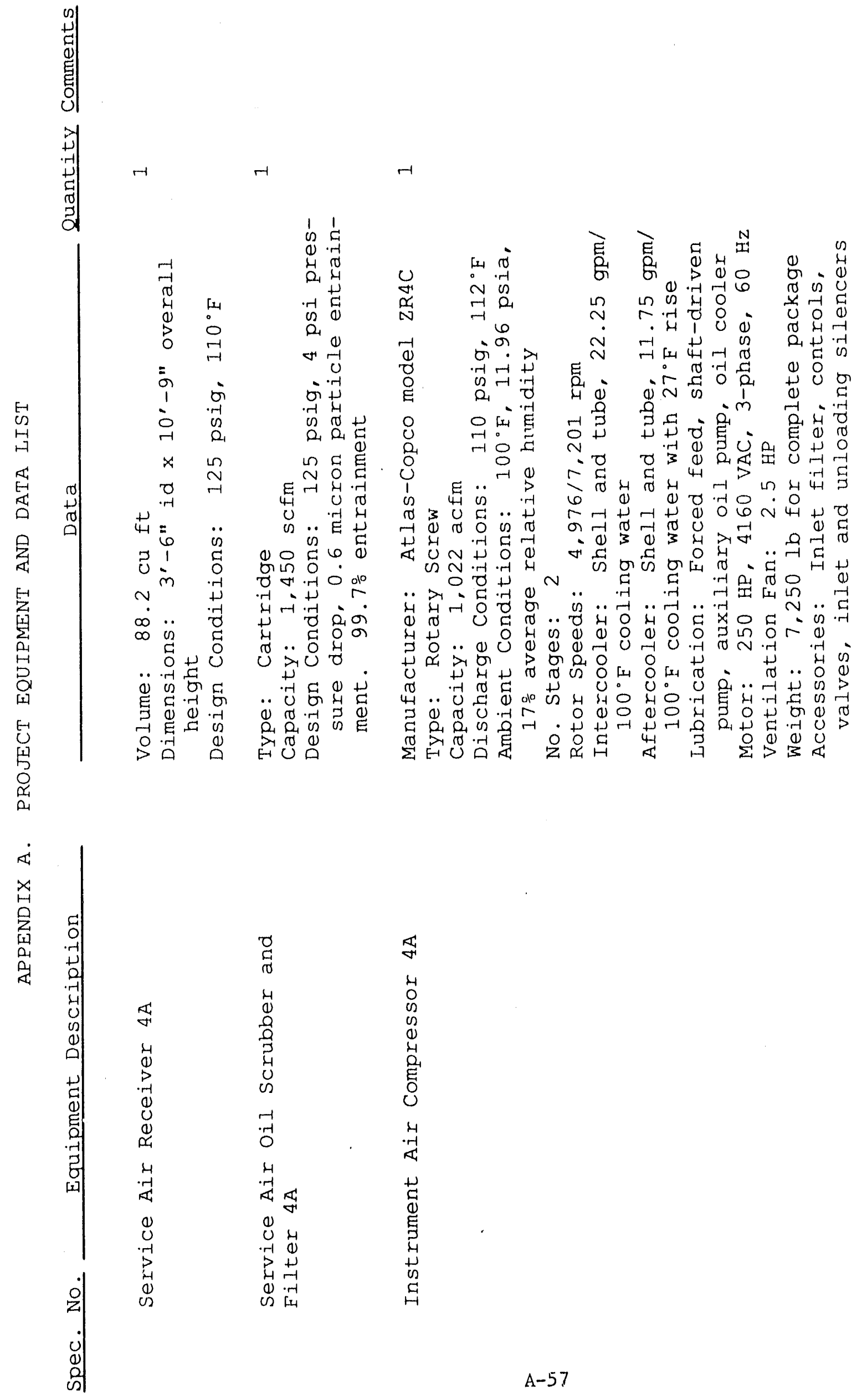


品

占

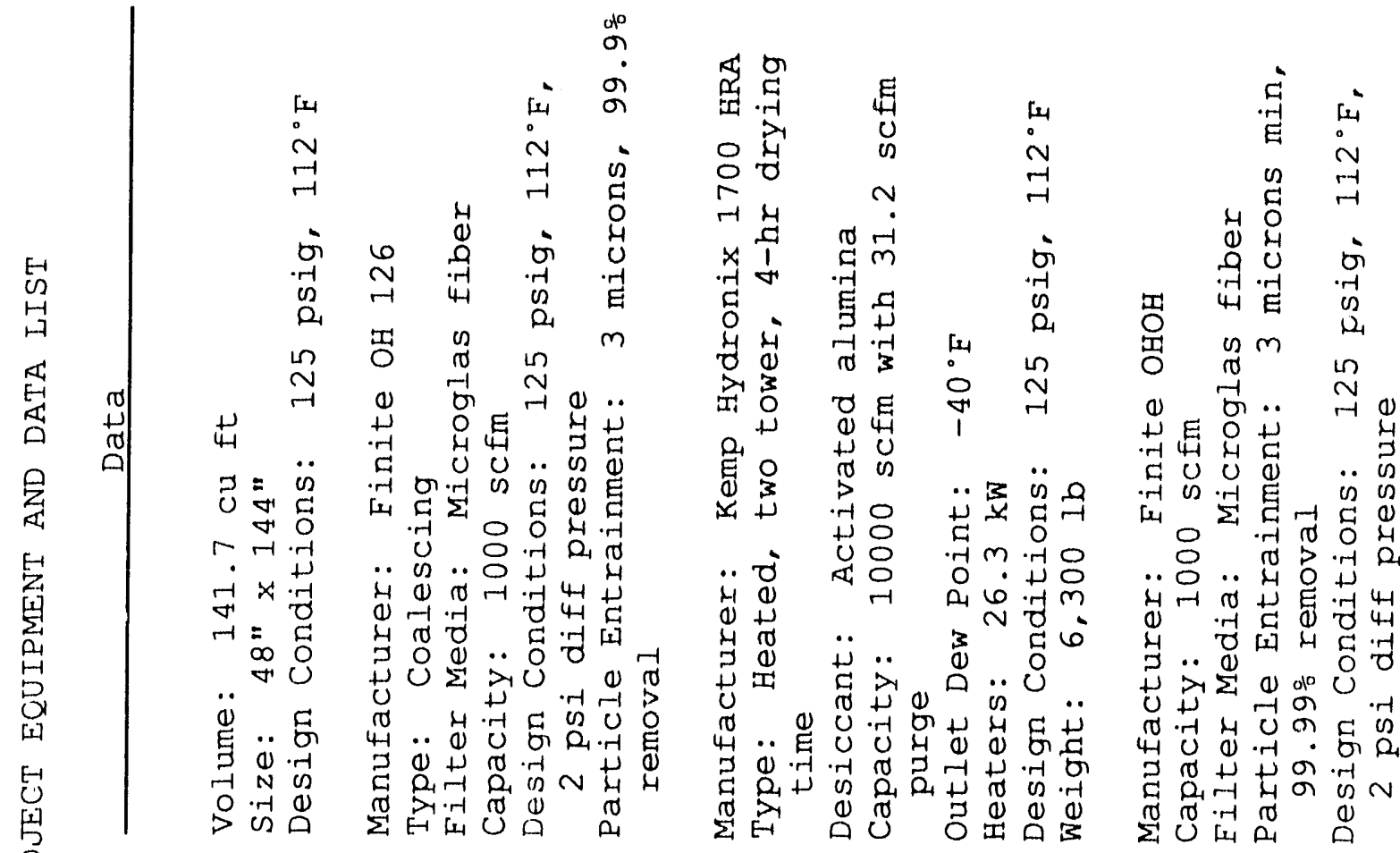

O

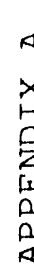

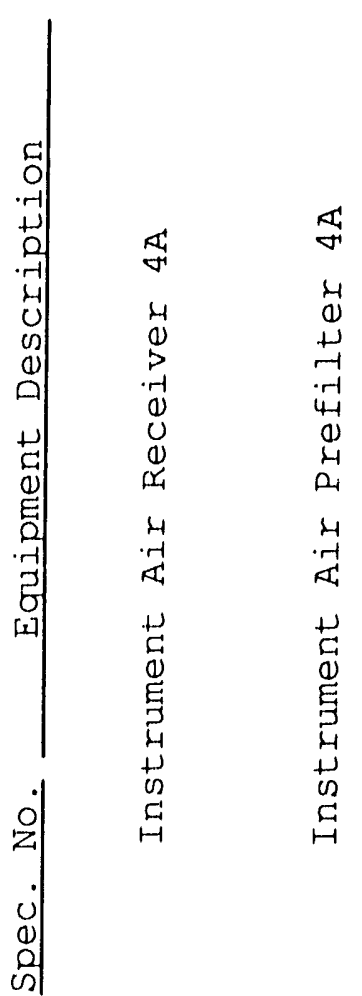

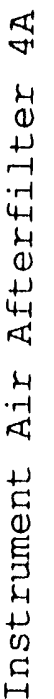




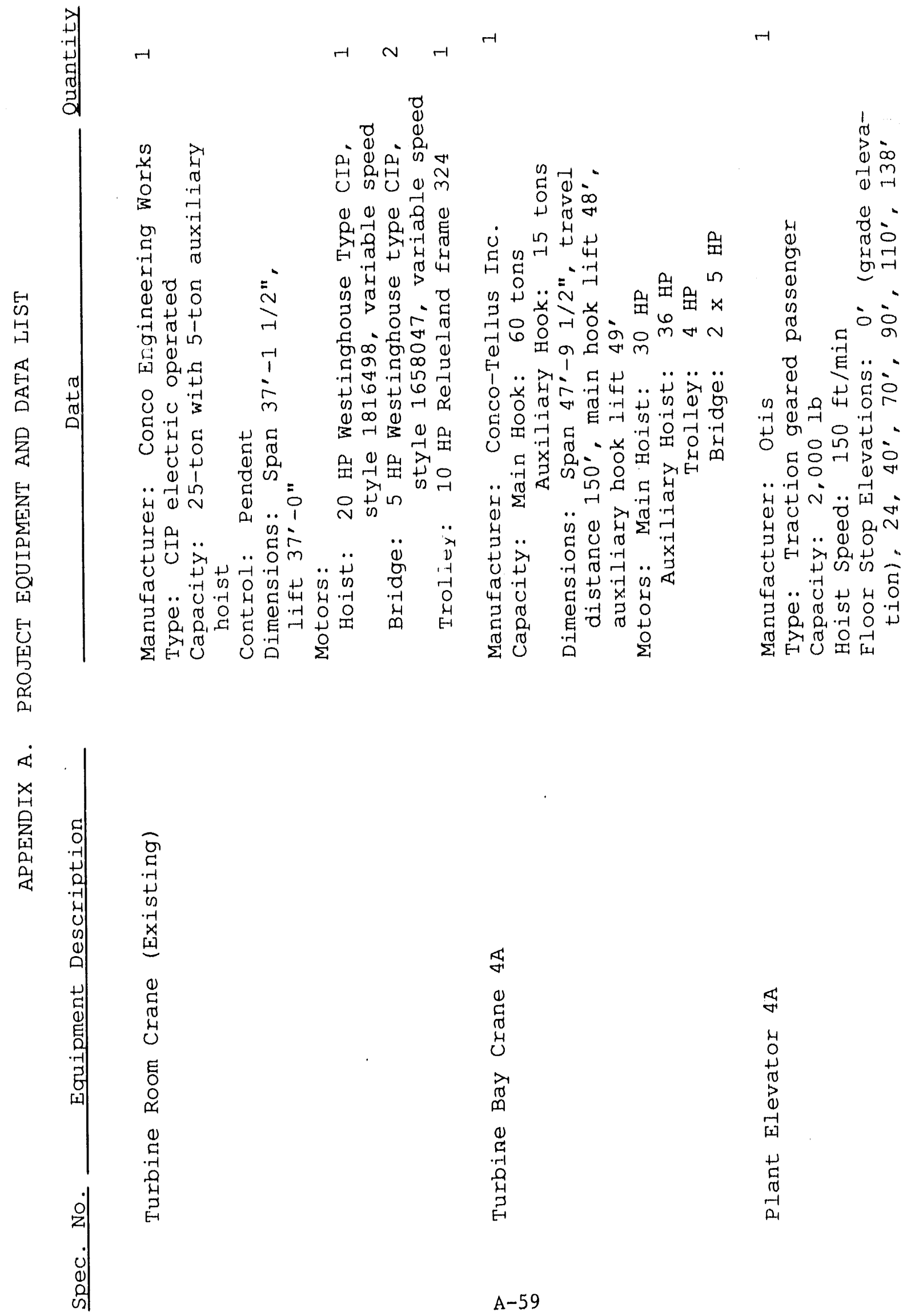


…
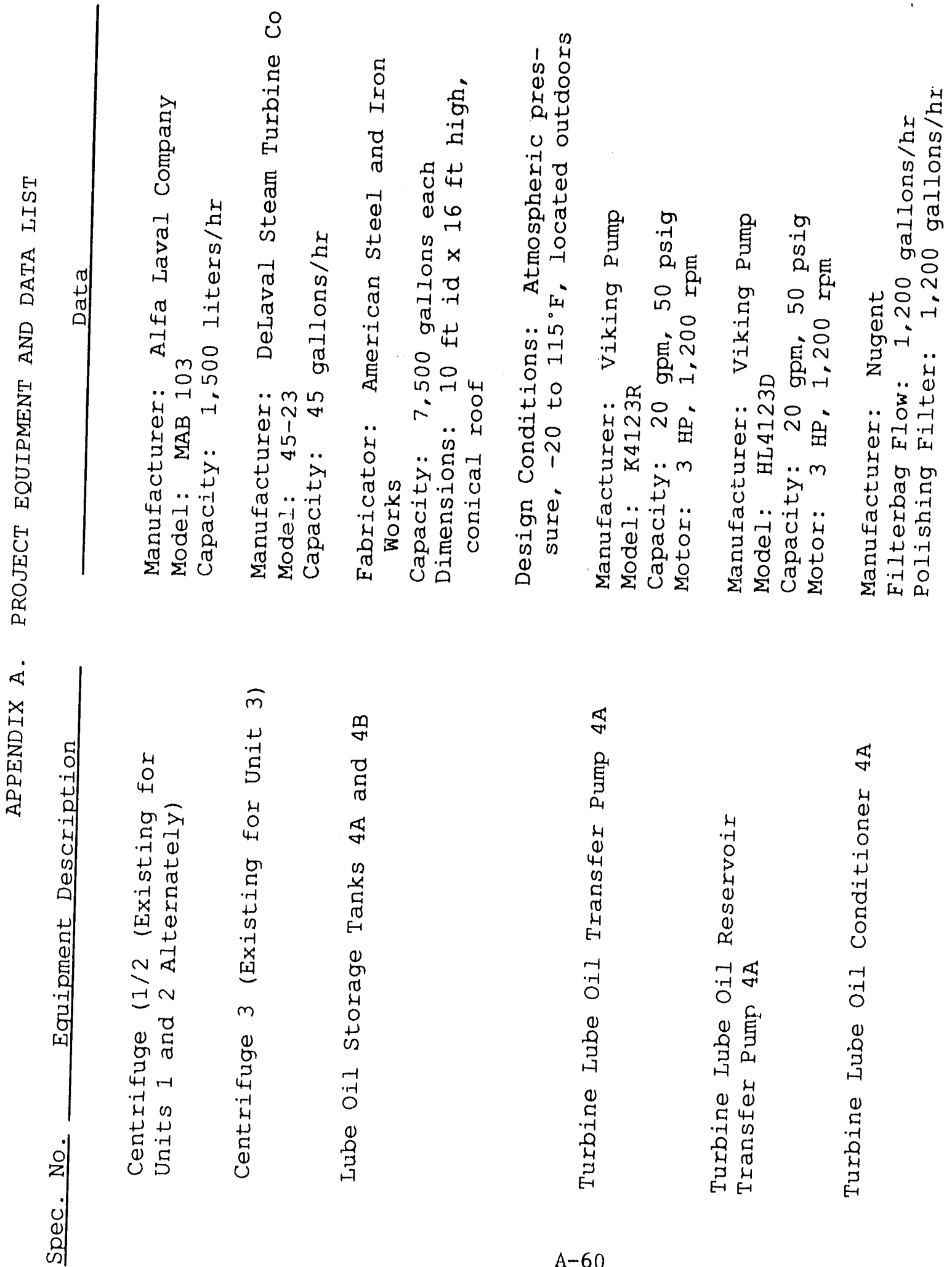
ठै $000-1$ पु 工 ते \% .. म

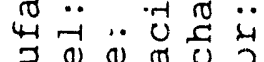

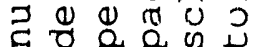

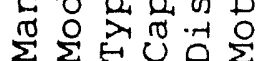

足

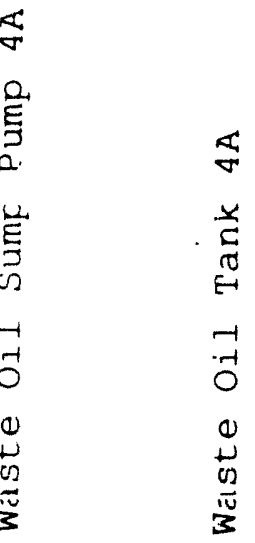

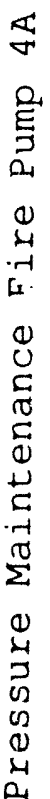



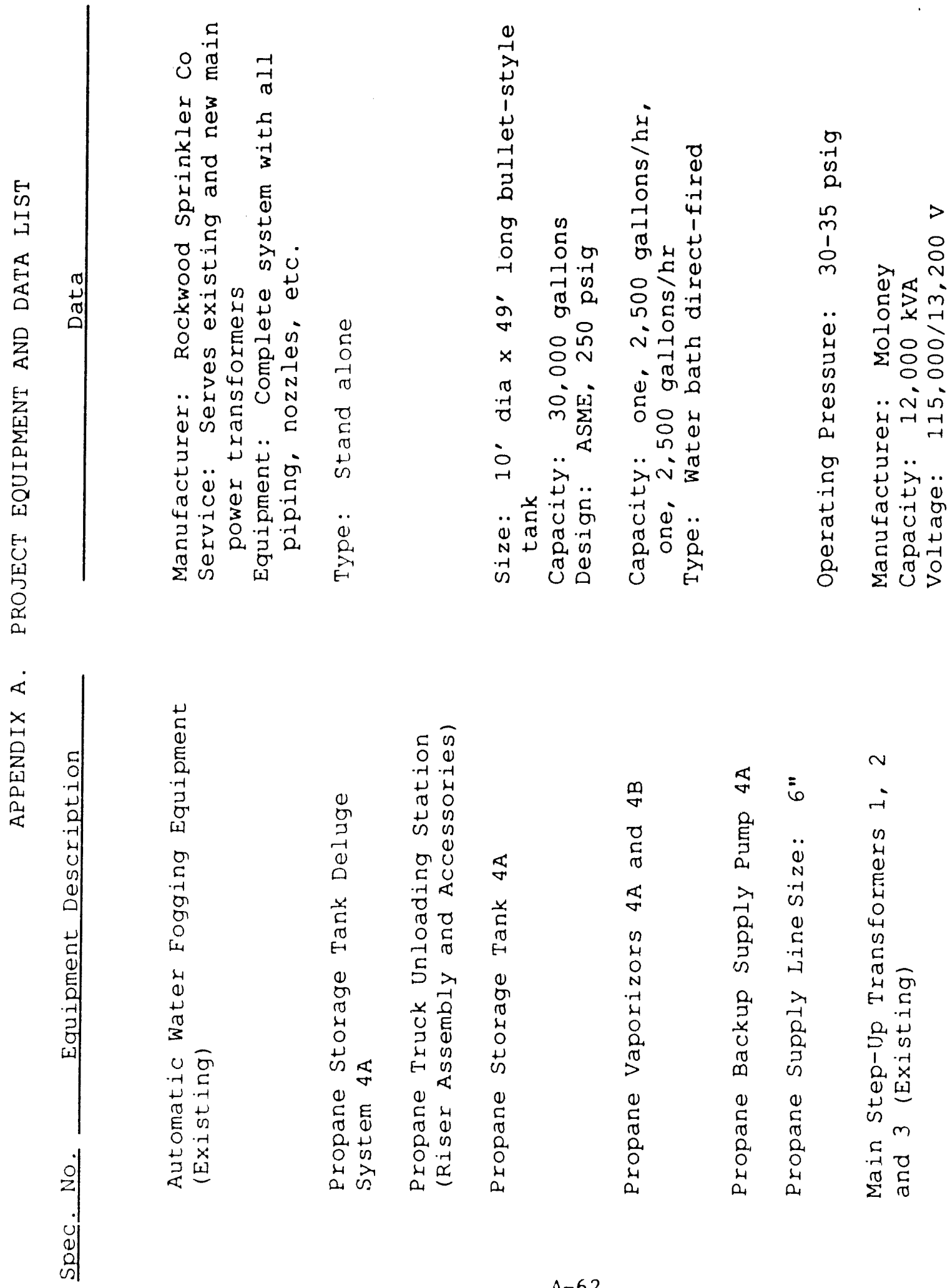


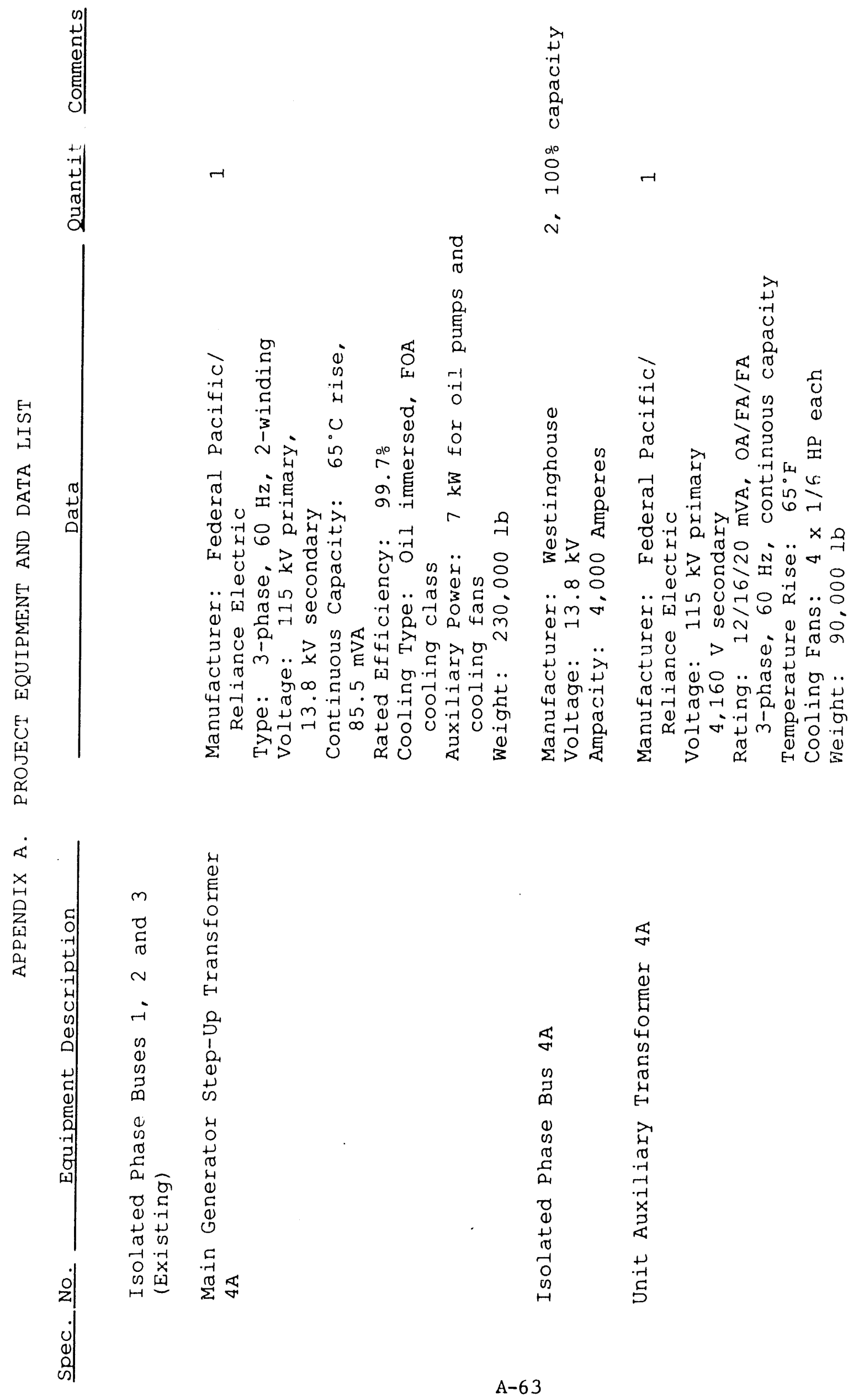




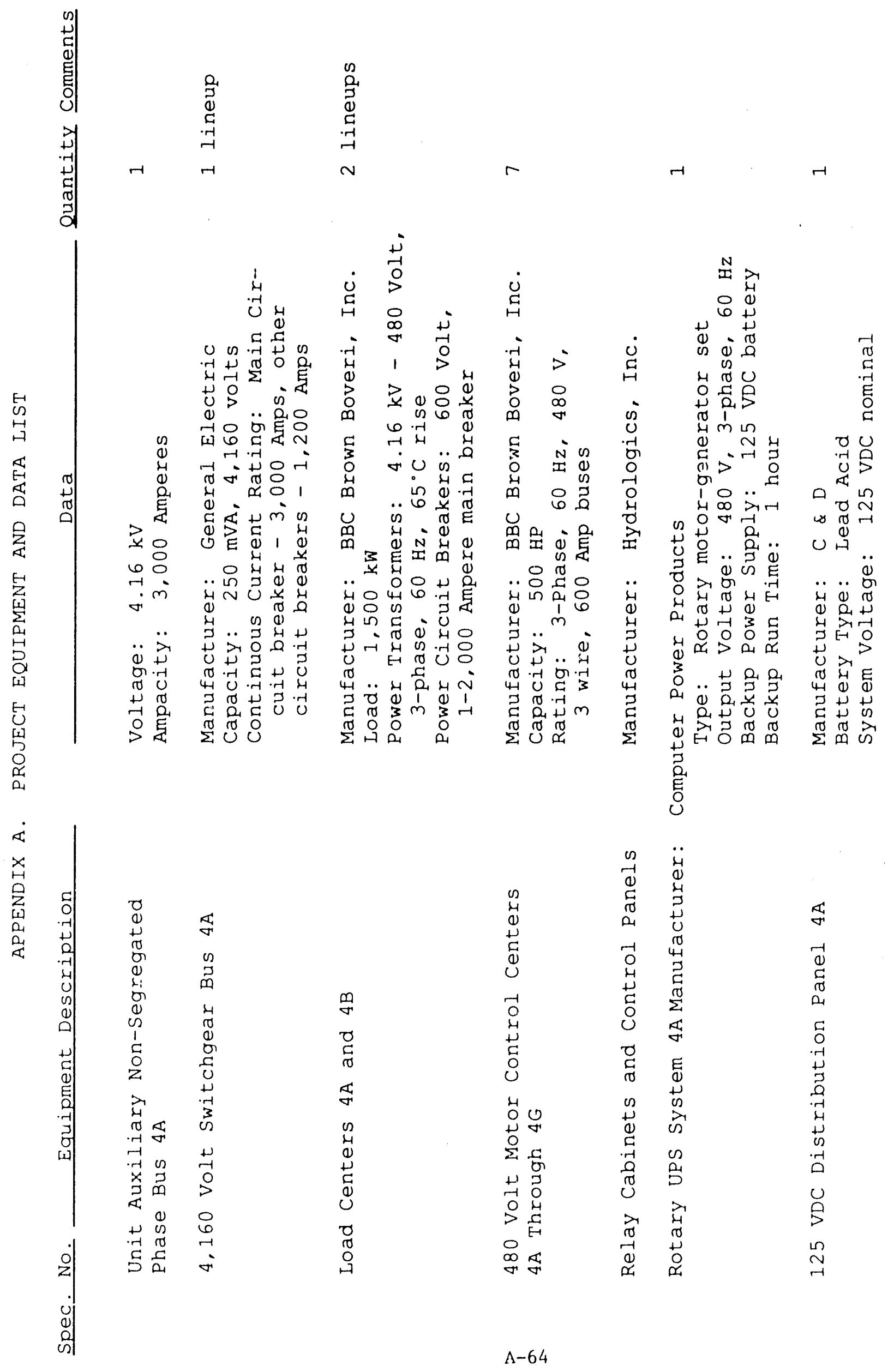




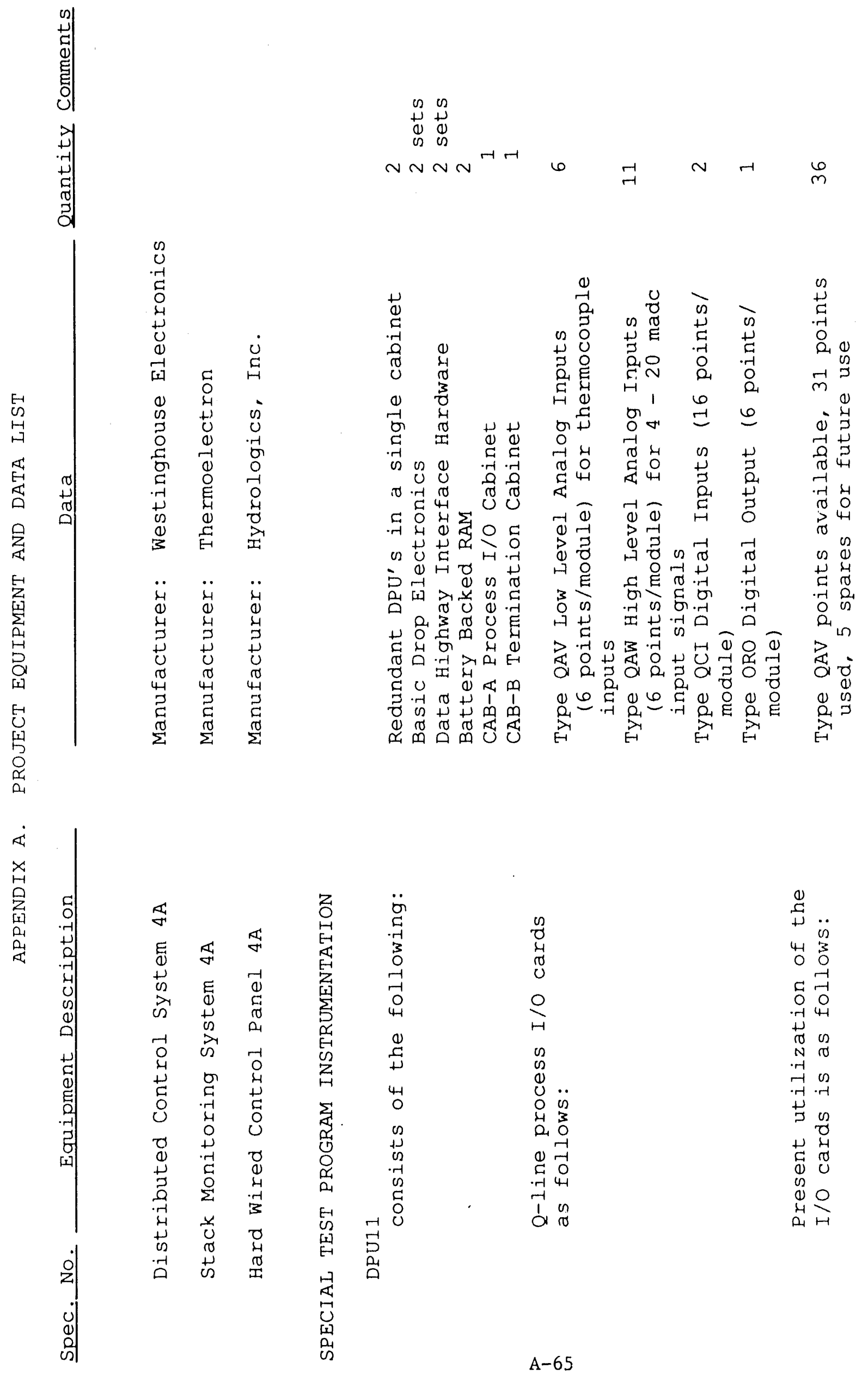




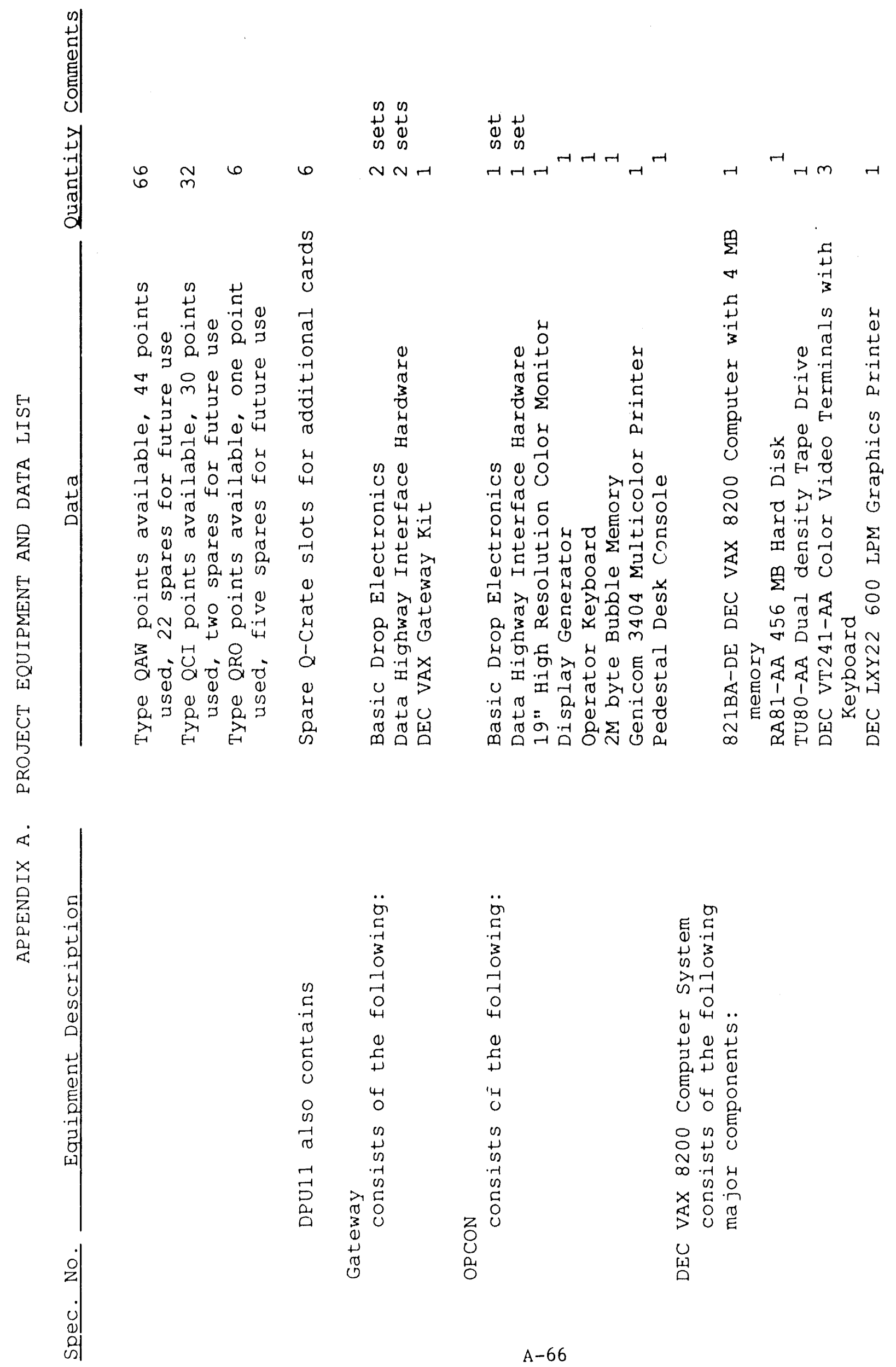




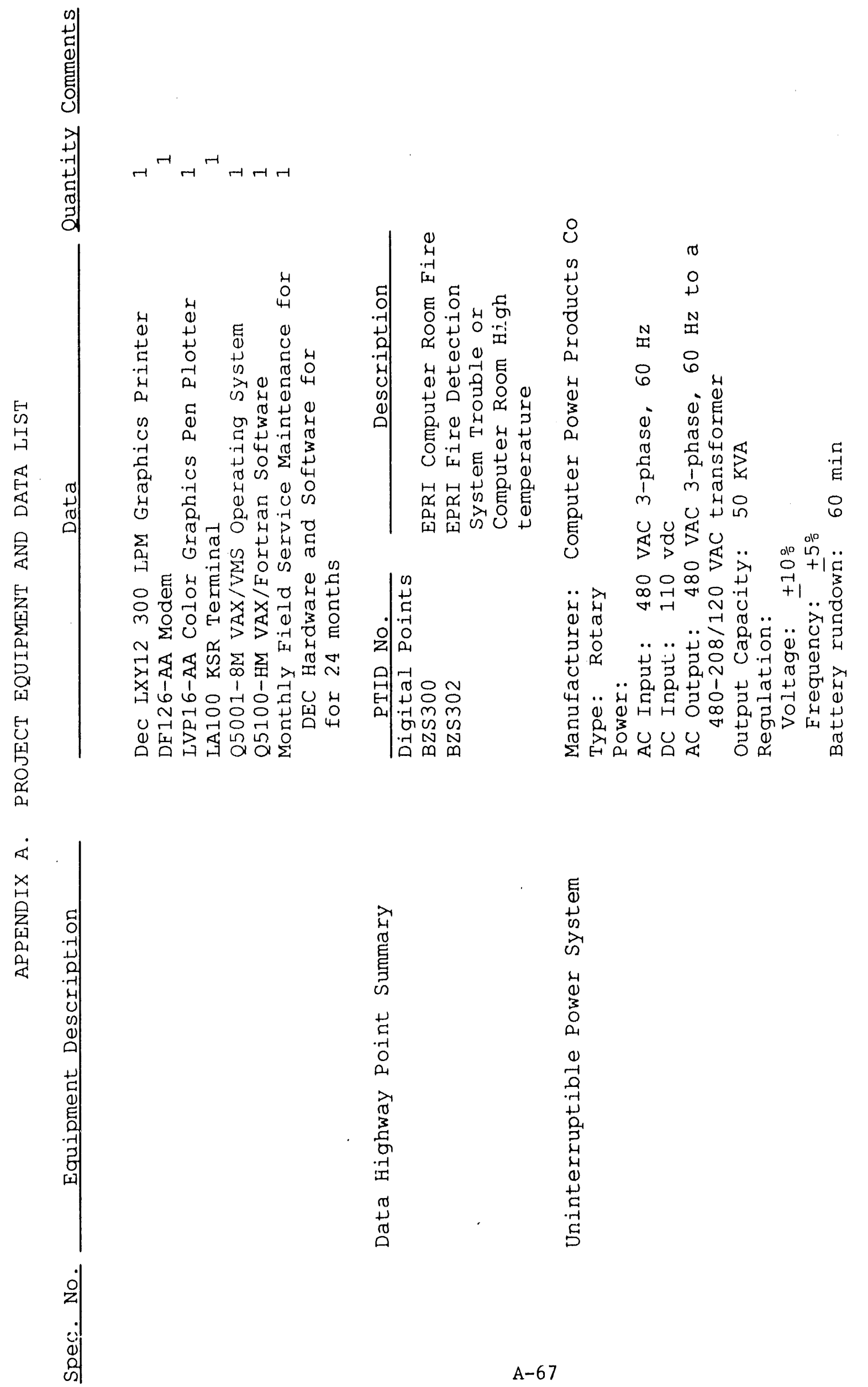




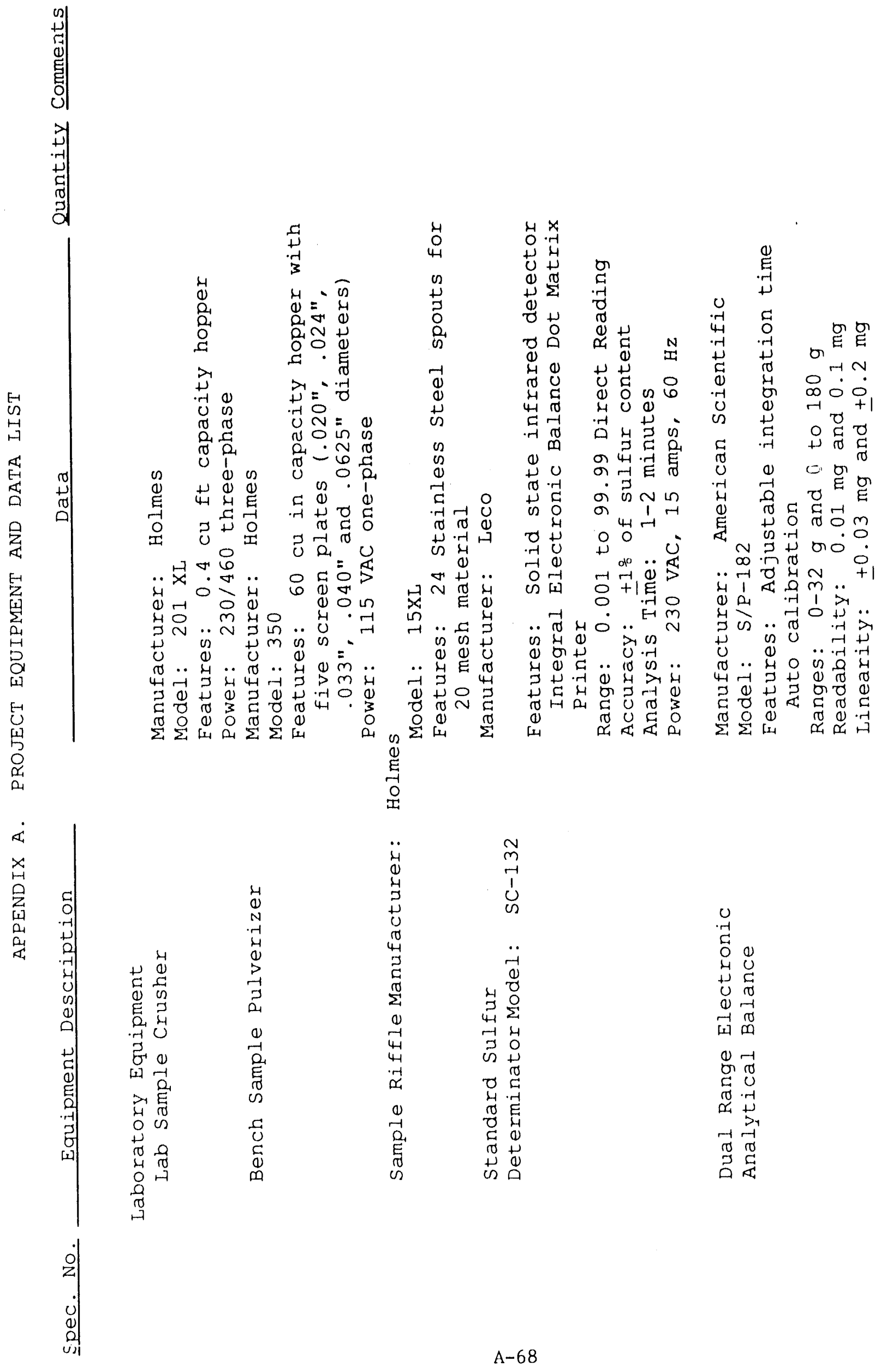




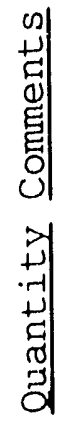

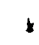

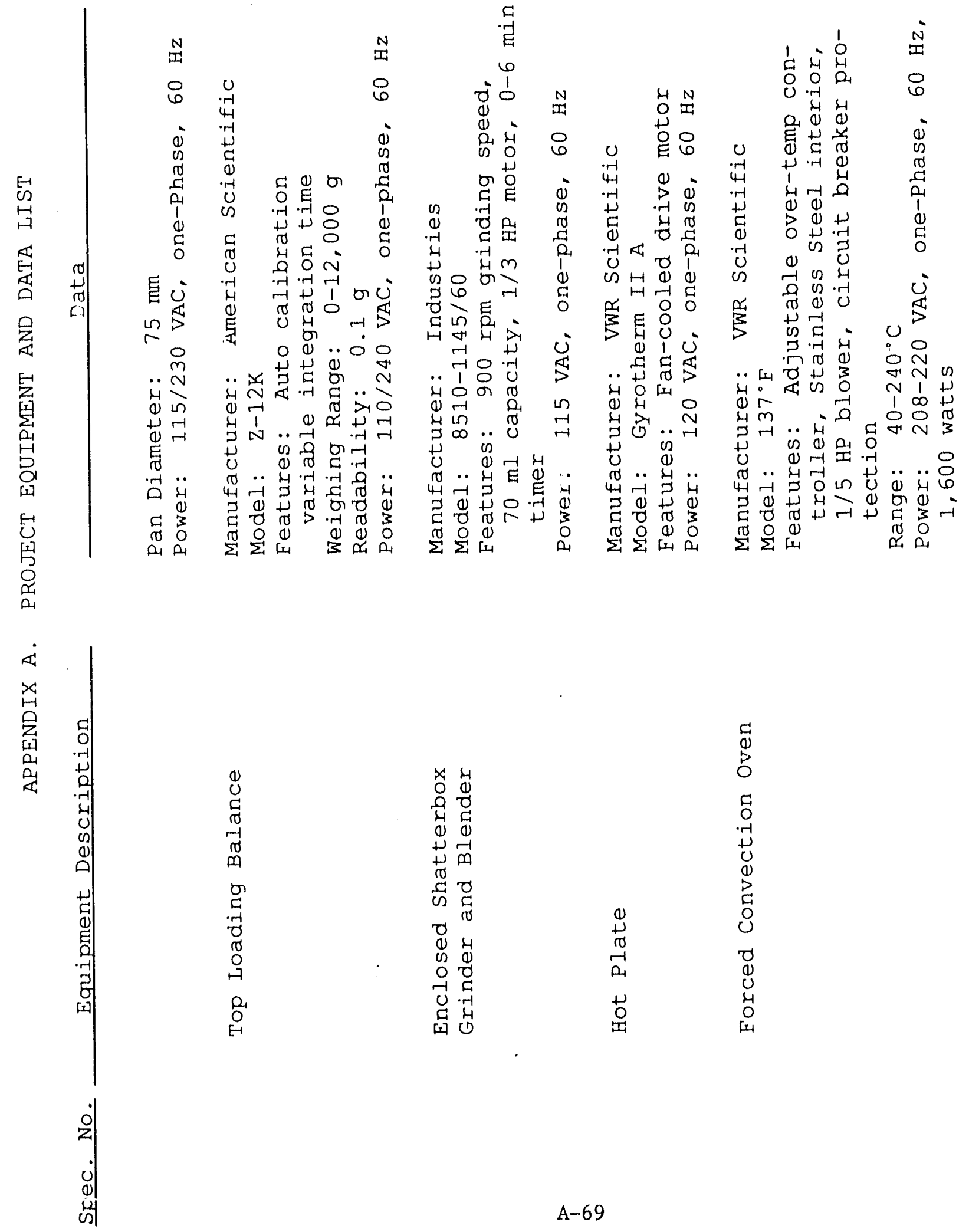




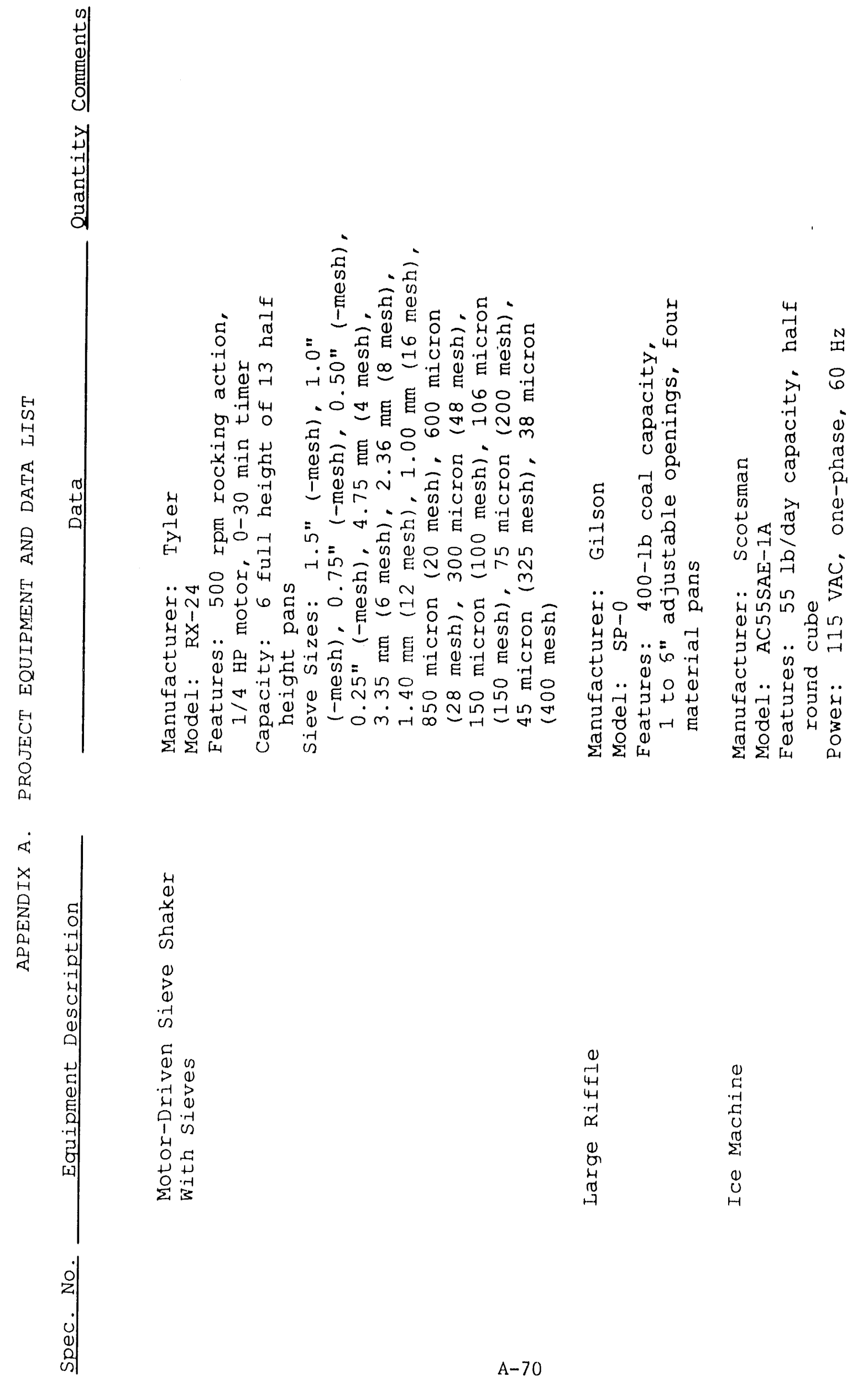




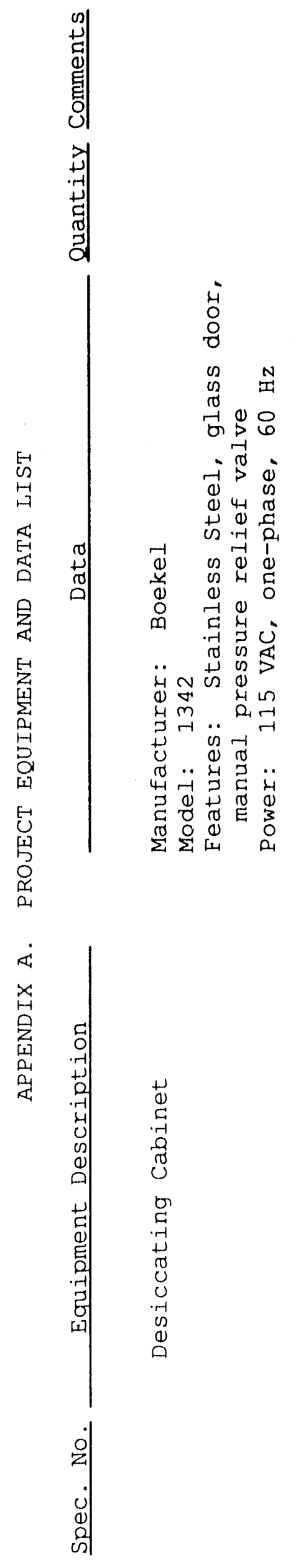


匈

in in in $m_{-1}^{m}$

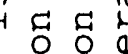

द्व $\cdot$.

然苟思

$\rightarrow>5$

(0) 10

(4)

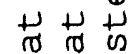

$\begin{array}{llll}0 & 0 & 0 & 0\end{array}$

4 Q

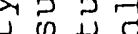

- $\begin{aligned} & 1 \\ & 0\end{aligned}$

$\sigma \quad 0)$

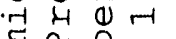

E ${ }_{1}$

0 䀯

0

(1) 4 क है

5 出 0

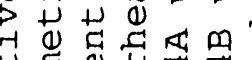

E्म क्म

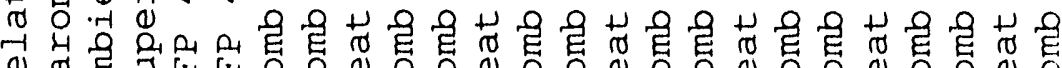

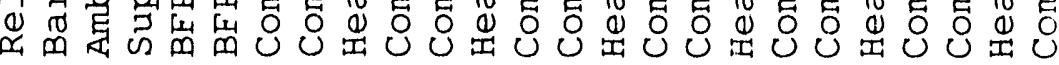

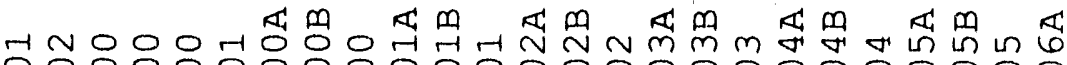

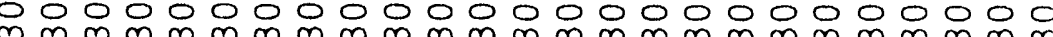

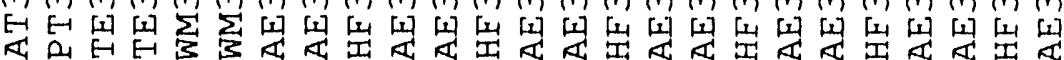

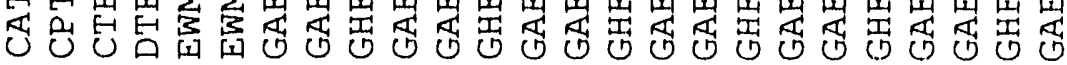

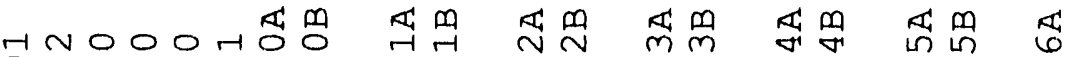

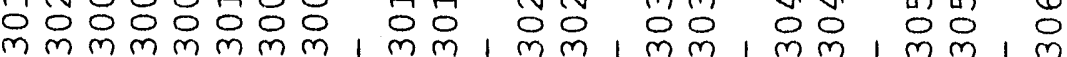

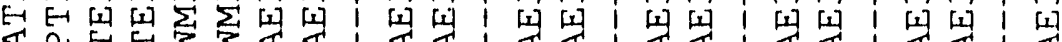

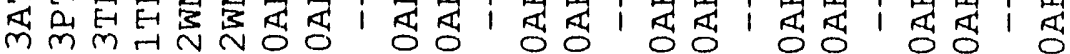

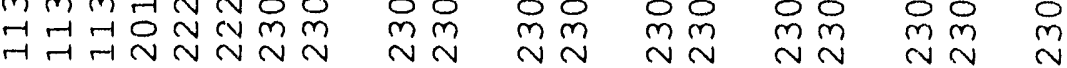




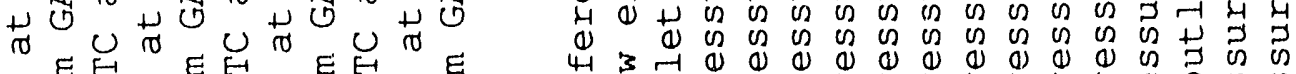

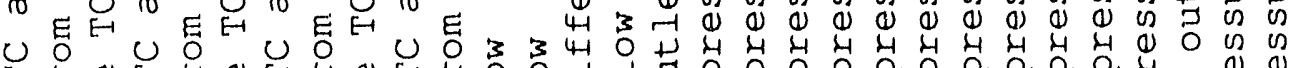

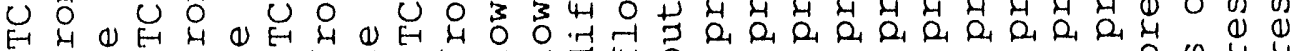

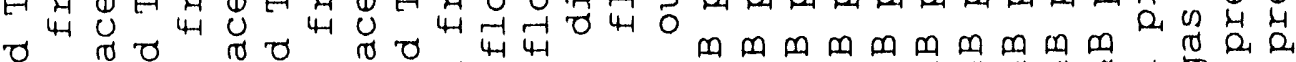
त ठ

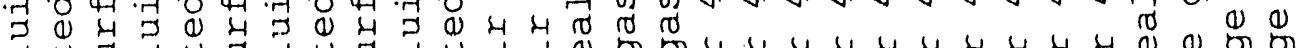

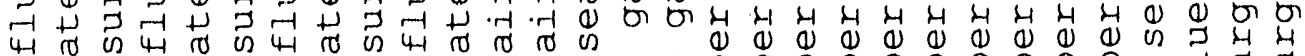

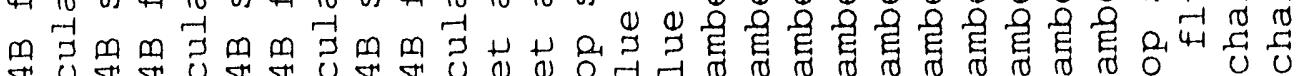

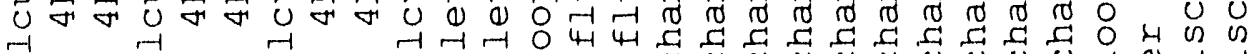
प

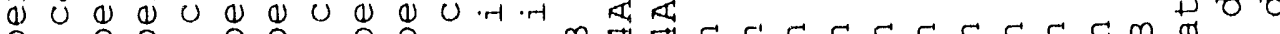

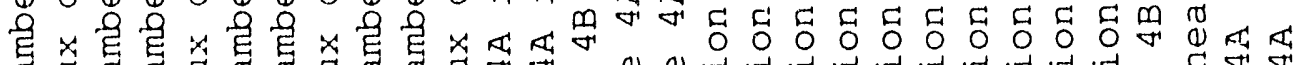

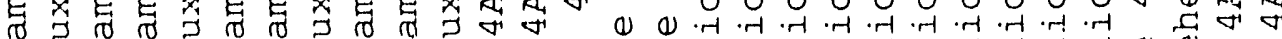

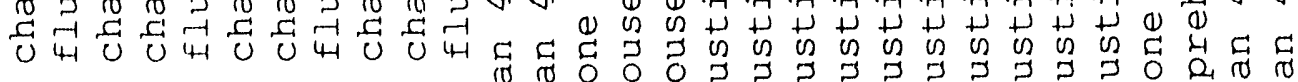

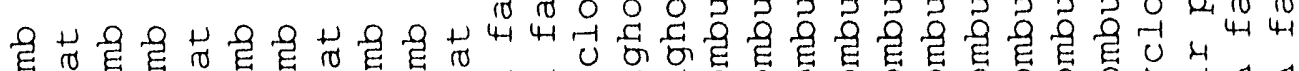

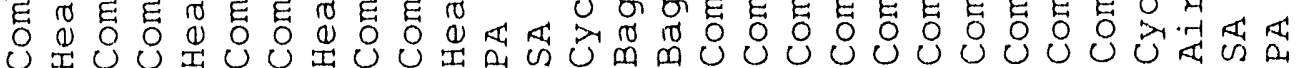

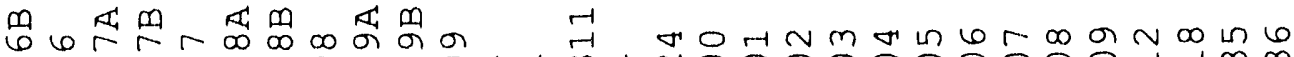

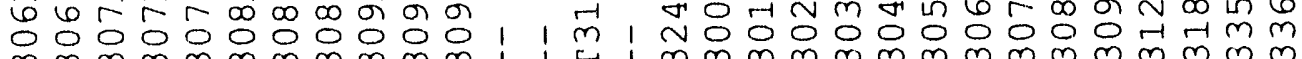

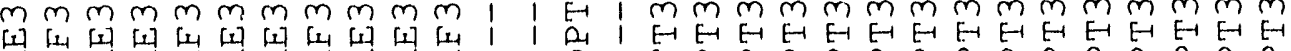

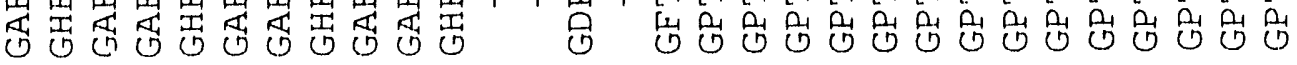

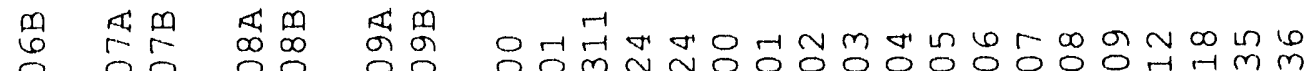

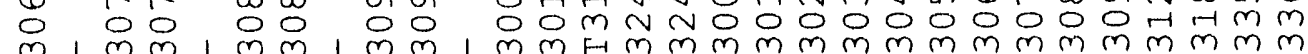

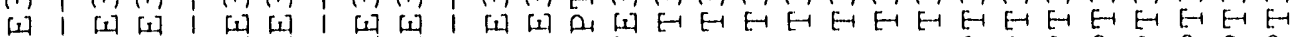

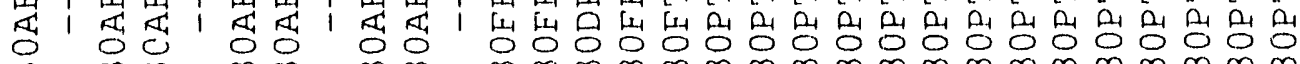
$\stackrel{m}{\sim} \stackrel{m}{\sim} \stackrel{m}{\sim} \stackrel{m}{\sim} \stackrel{m}{\sim} \stackrel{m}{\sim} \stackrel{m}{\sim} \stackrel{m}{\sim} \stackrel{m}{\sim} \stackrel{m}{\sim} \stackrel{m}{\sim} \stackrel{m}{\sim} \stackrel{m}{\sim} \stackrel{m}{\sim} \stackrel{m}{\sim} \stackrel{m}{\sim} \stackrel{m}{\sim} \stackrel{m}{\sim}$ 
山范山m

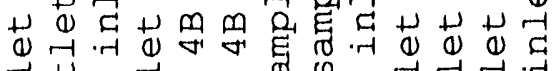

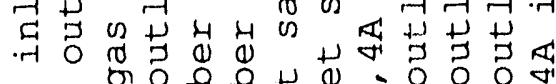

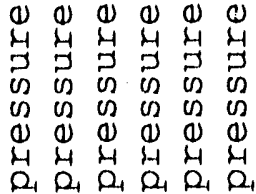

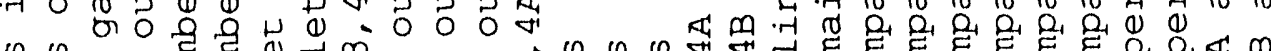

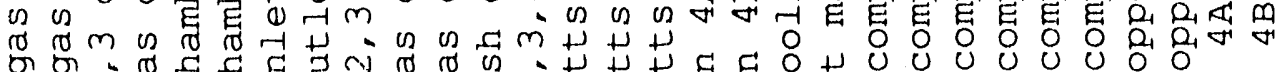
G 承计

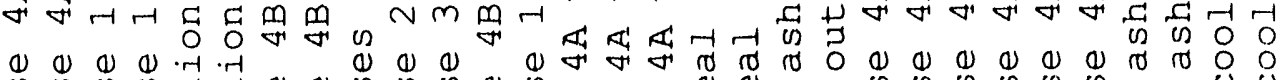

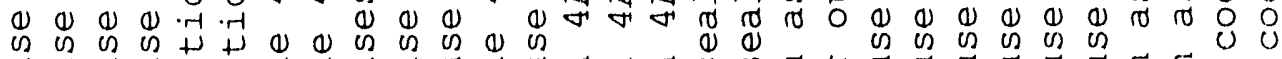

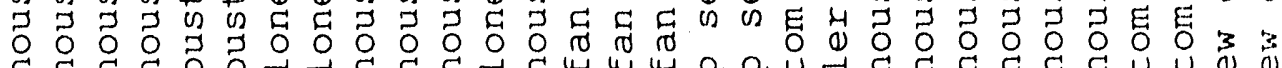

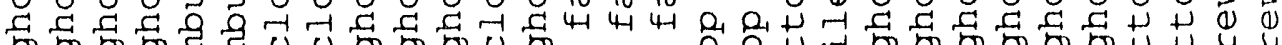

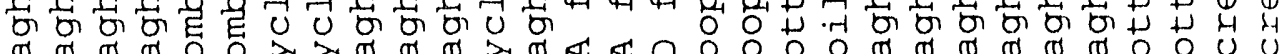
西

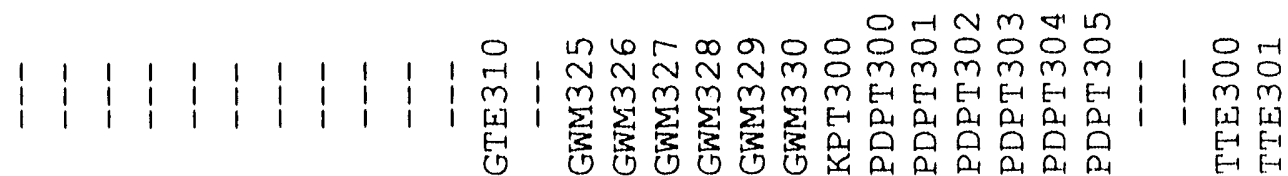

OHCMOHNm N $N \underset{N}{N}$ in

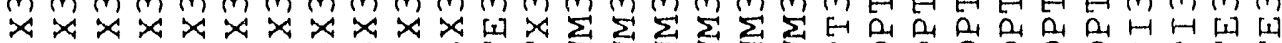

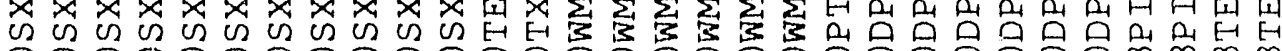
m

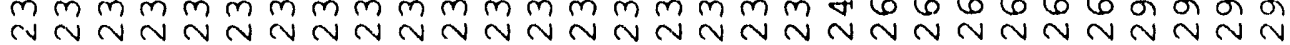




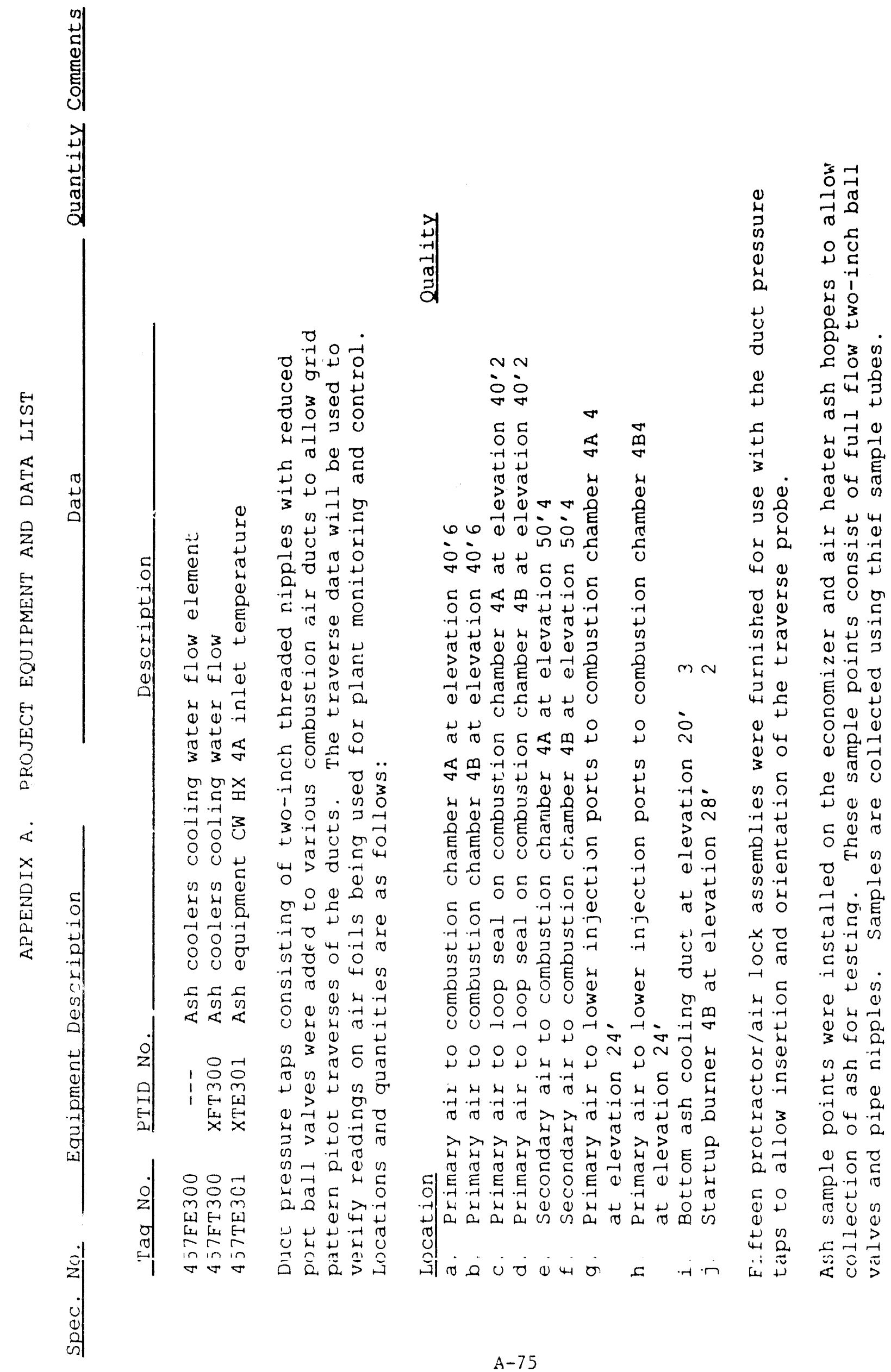


थ

7
+1
+1
பี
0
3
0

ل)
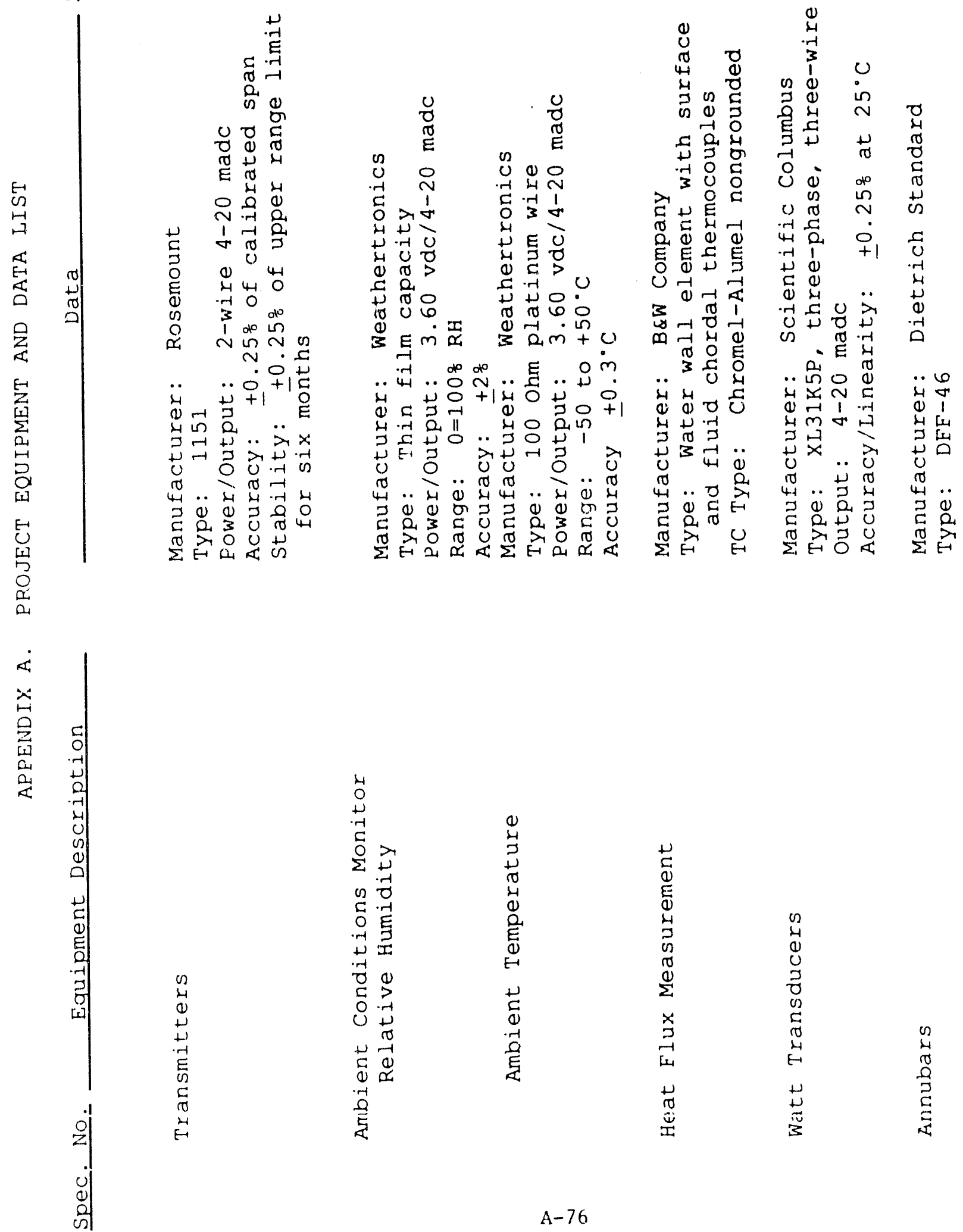

0
4
0
0
3
$\Xi$
$\vdots$ 


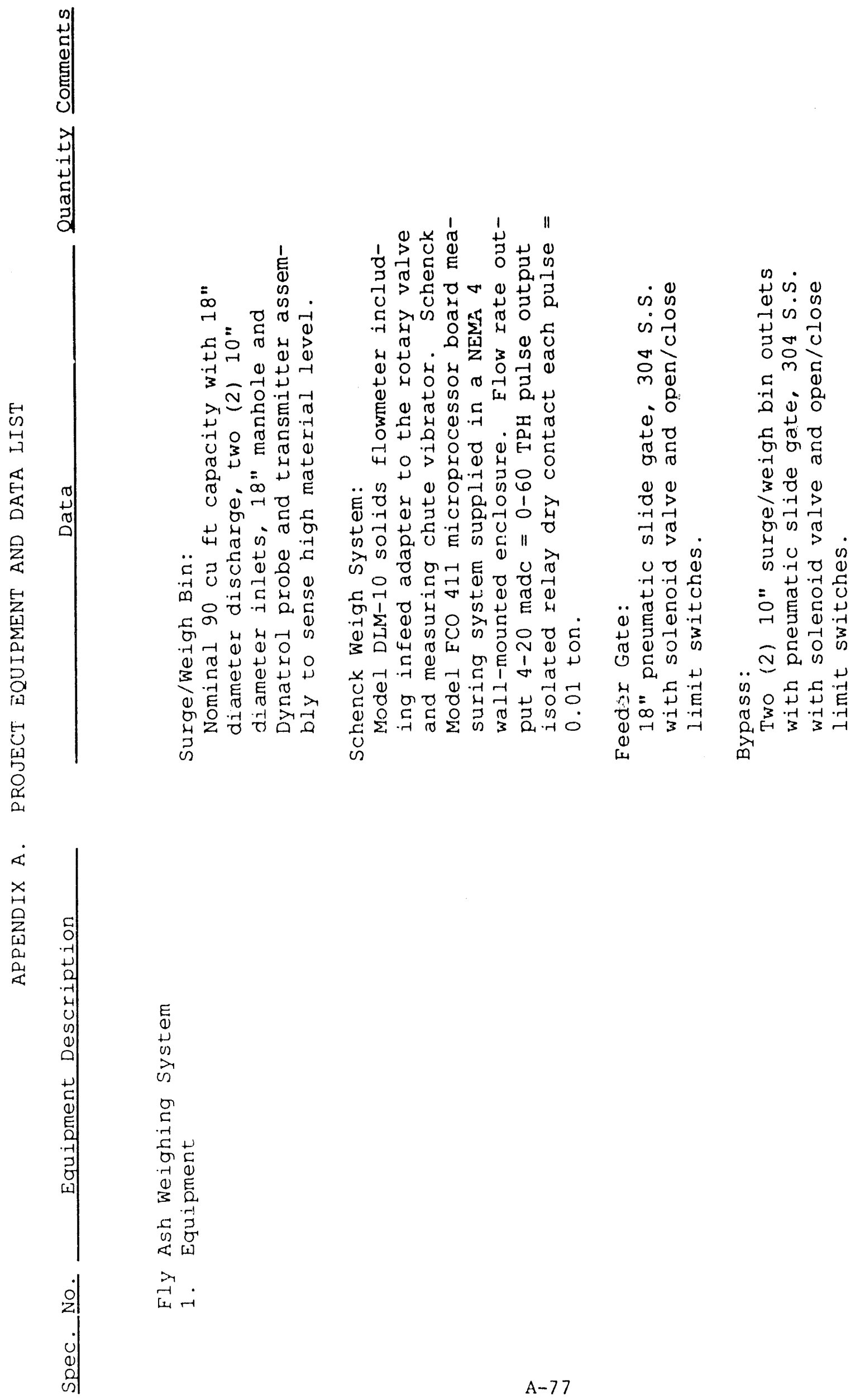




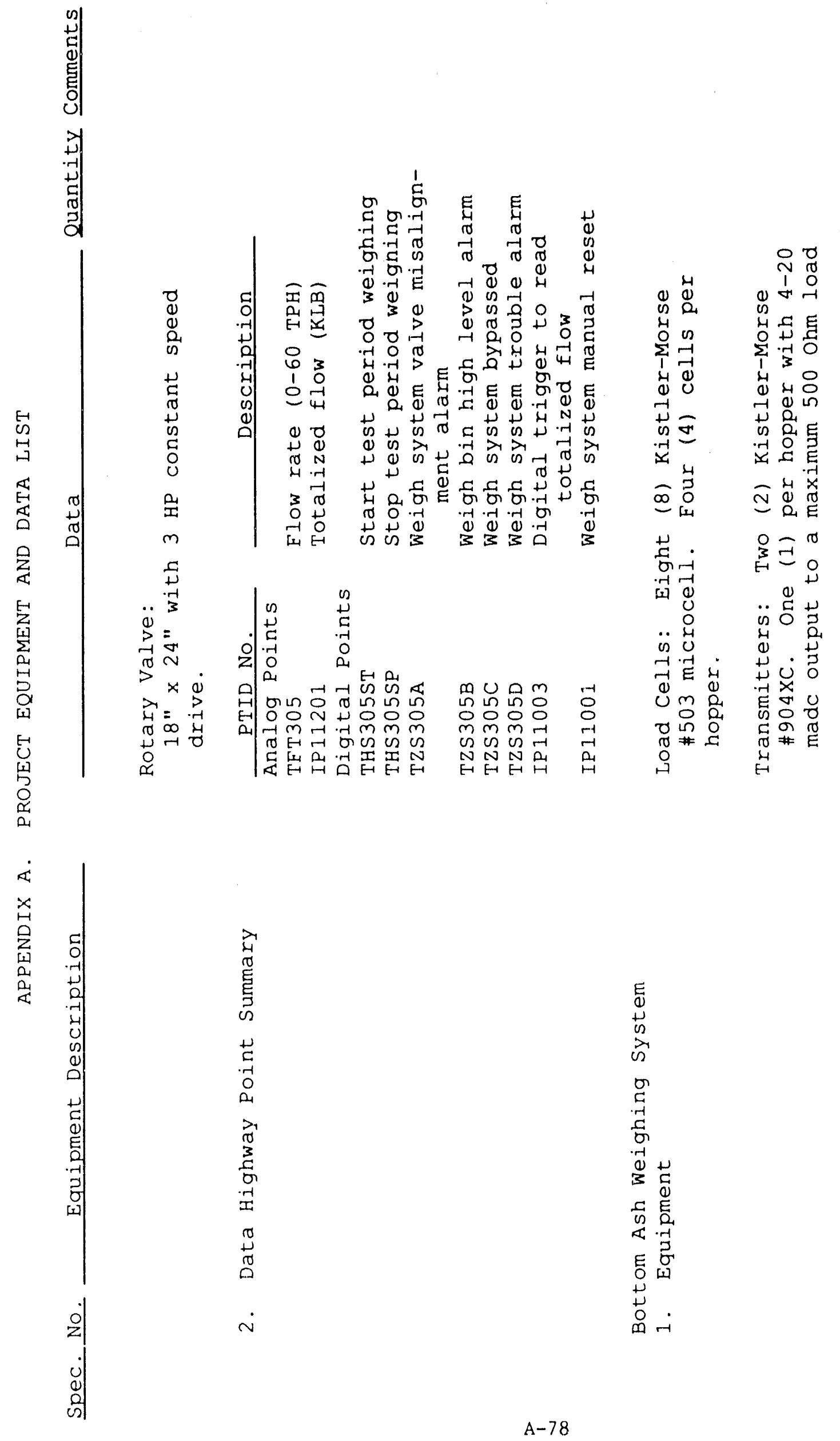




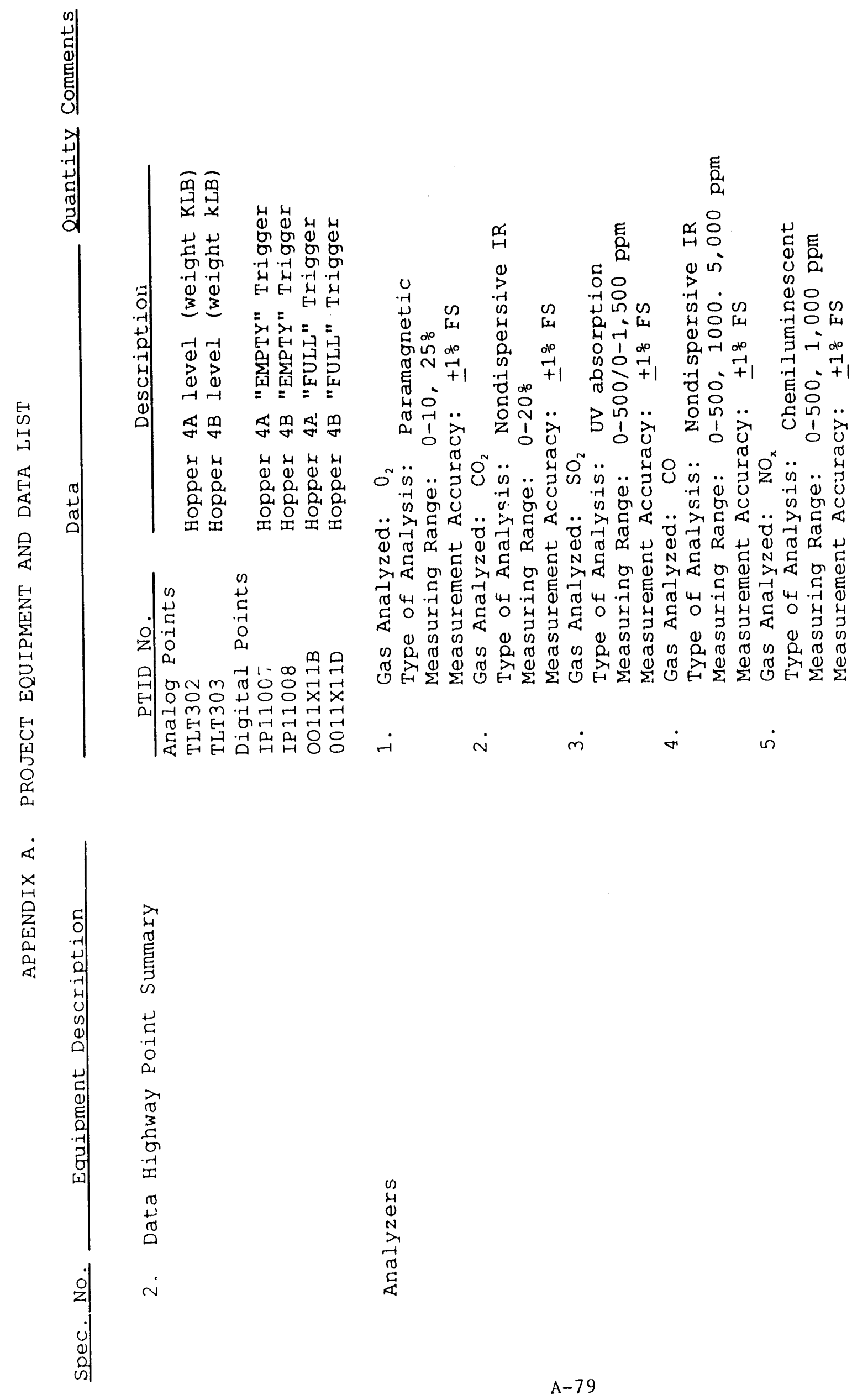




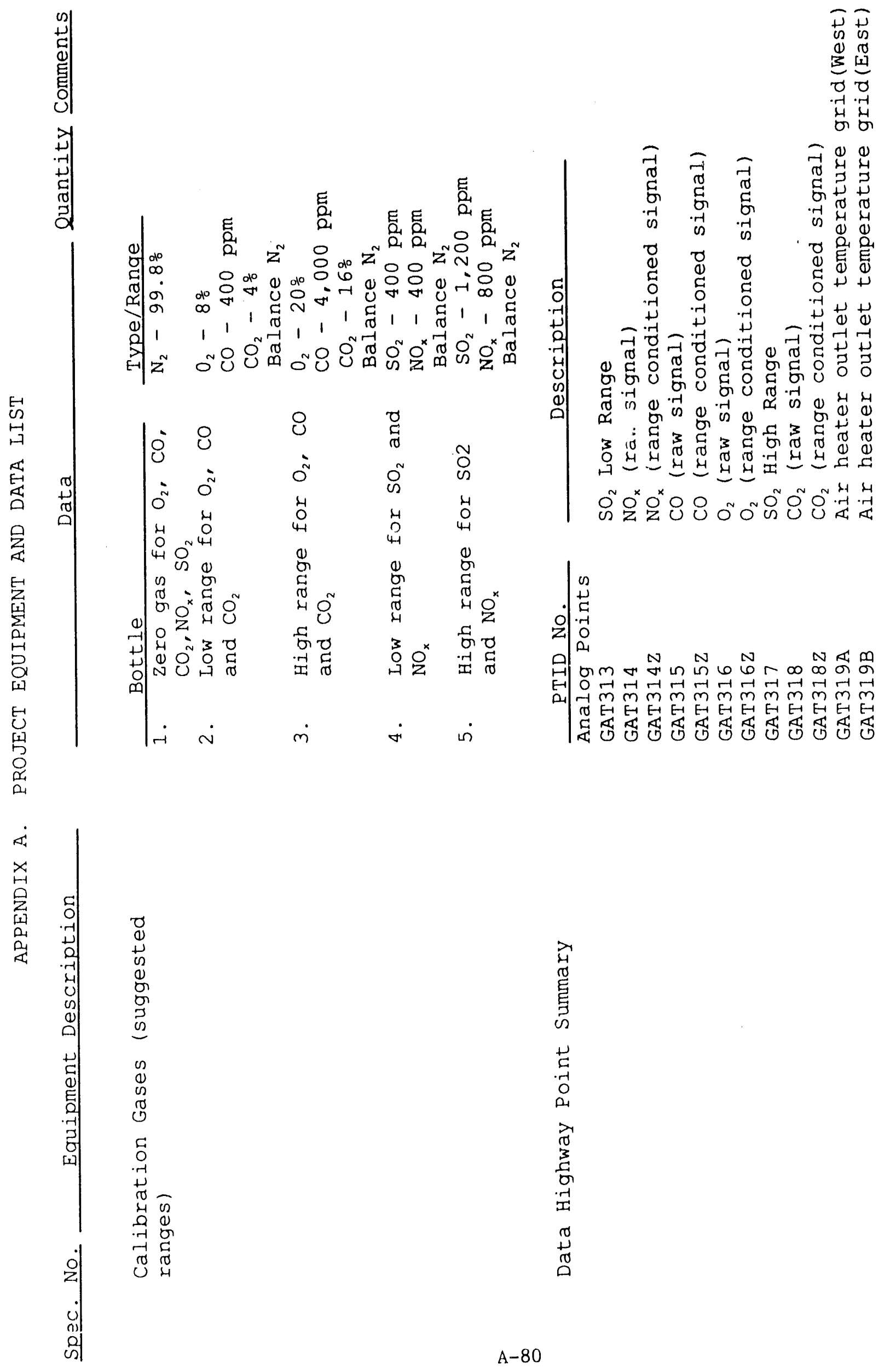




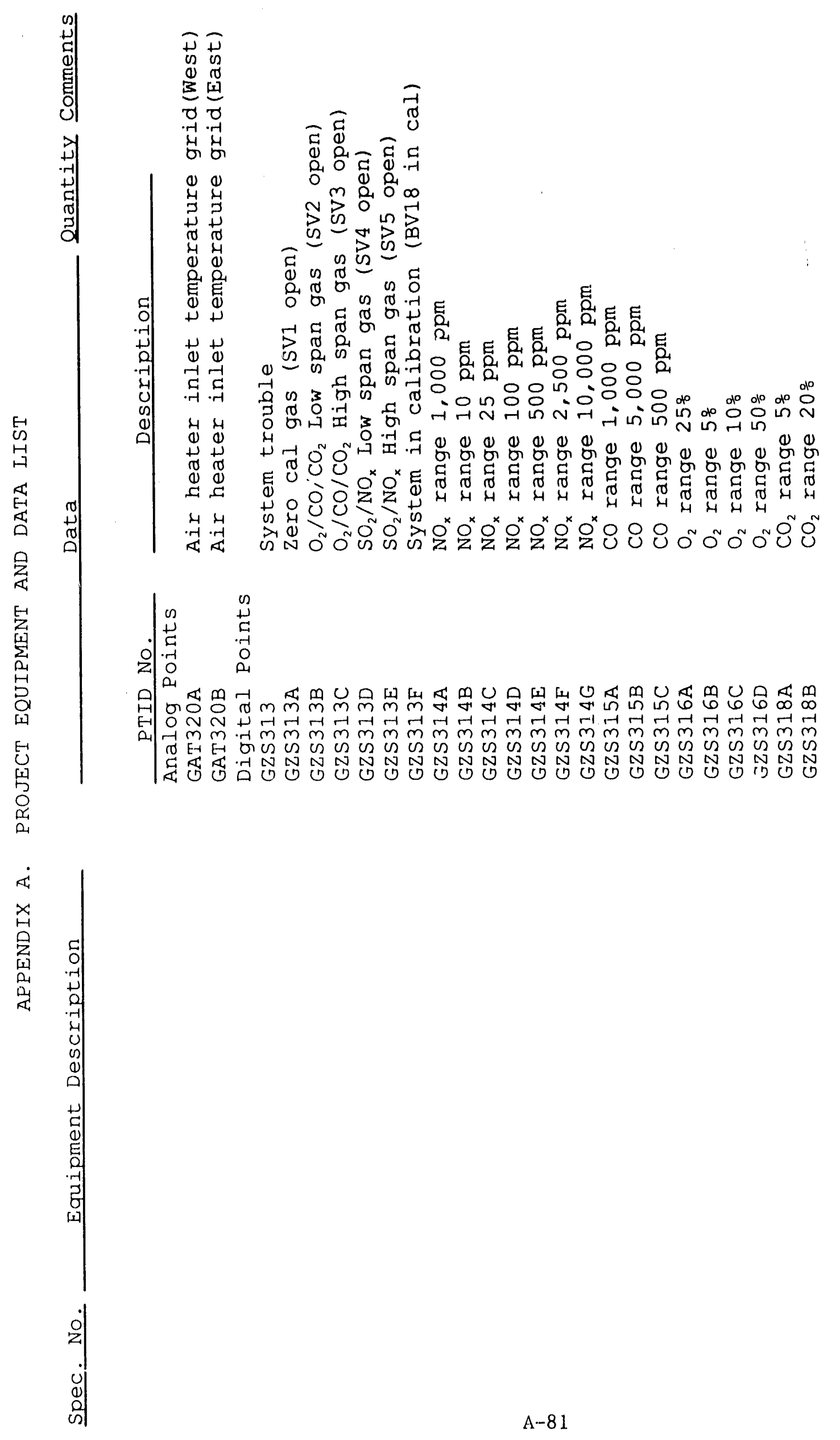




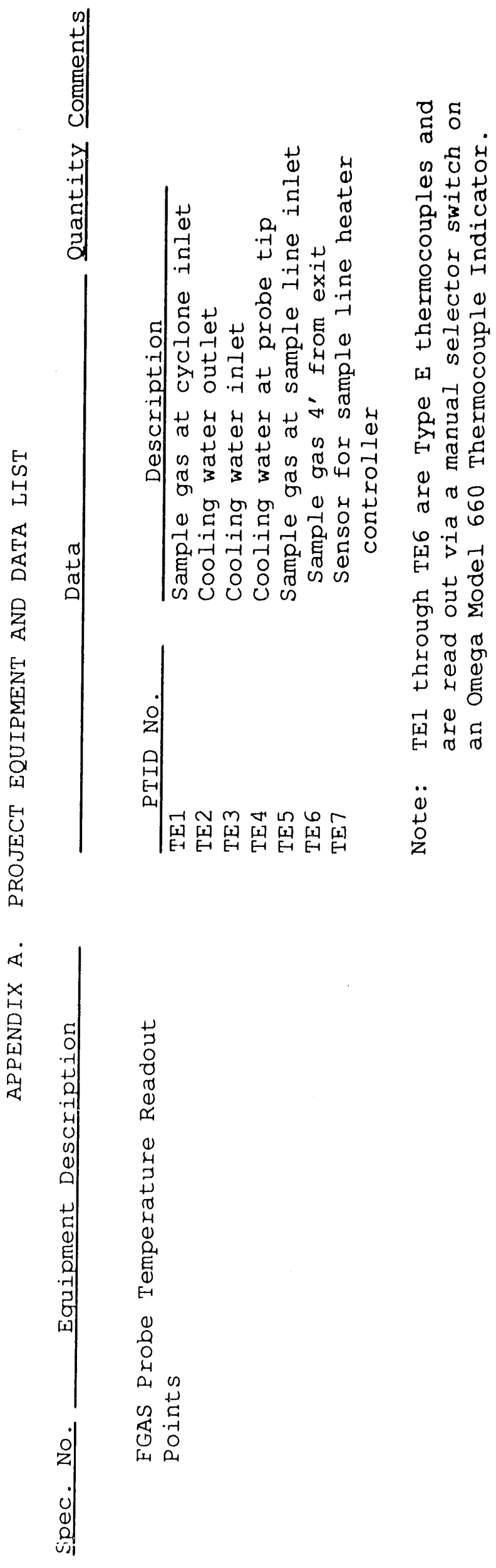


NUCLA CFB DEMONSTRATION PROJECT

\title{
PROJECT PUBLIC DESIGN REPORT
}

\author{
APPENDIX B \\ NON-PROPRIETARY \\ PROCESS AND INSTRUMENTATION DRAWING \\ INDEX
}

(Bound Separately) 
APPENDIX B. NON-PROPRIETARY

PROCESS AND INSTRUMENTATION DRAWING

Section

Contents

Exhibit

Number

Number

1. Stearns Catalytic Corporation

Denver, Colorado

Process Flow and Instrumentation Drawings

Number Title

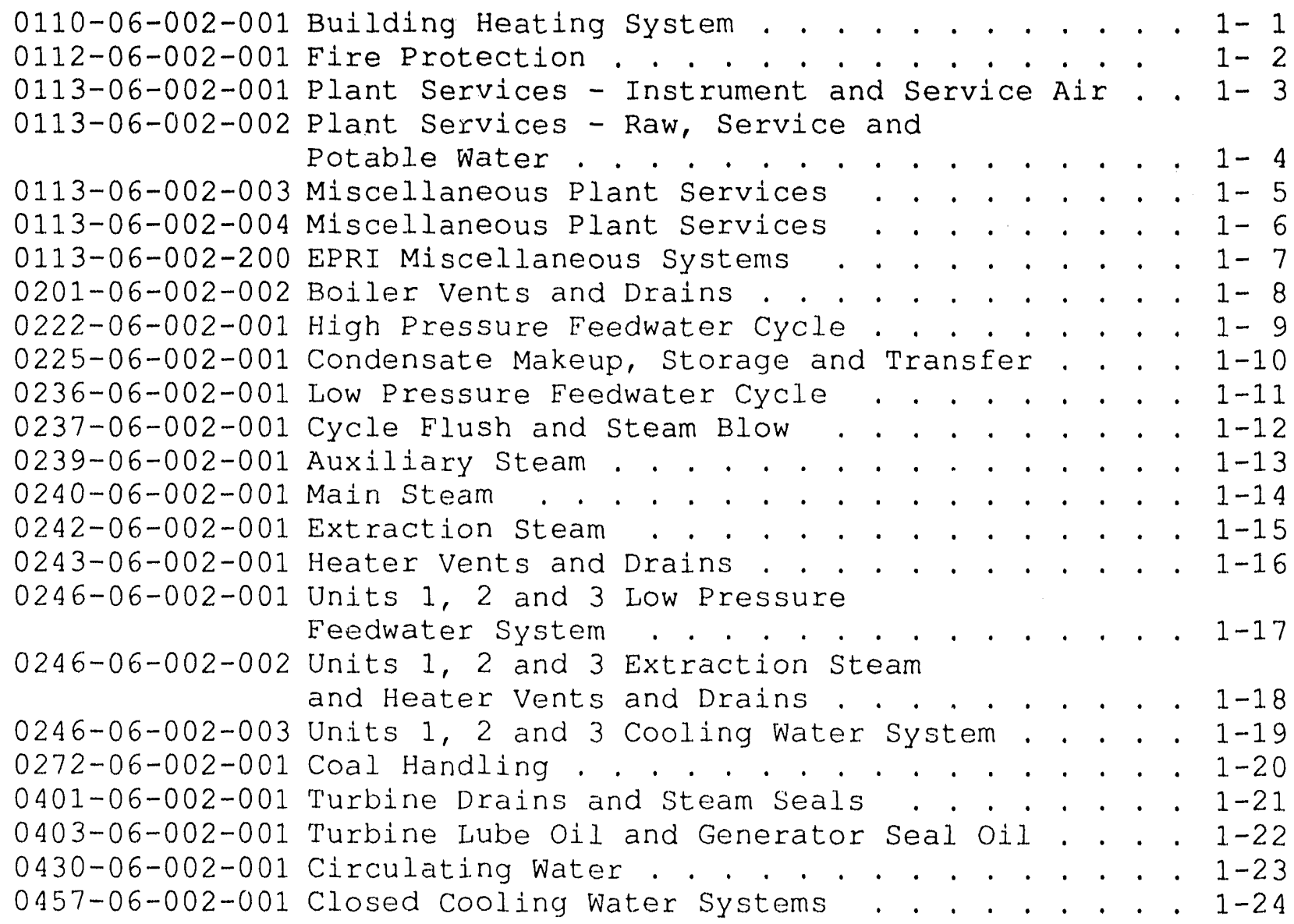


2. Westinghouse Electric Corporation

Orlando, Florida

Process Flow and Instrumentation Drawings

Number

$777 \mathrm{~J} 522$

$777 \mathrm{~J} 521$
Title

E. H. Fluid System and . . . . 2-1, 2-2, 2-3, 2-4 Lubrication Diagram Sheet 1 through sheet 4 Piping Oil Flow Diagram Sheet 1. . . . . . 2-5

3. Research-Cottrell

Somerville, New Jersey

Process Flow and Instrumentation Drawings

$\Lambda_{1}$ mber Title

6036-006-103-B Existing Baghouse No. 1............ . 3-1

6036-006-104-B Existing Baghouse No.2... . . . . . . . . 3-2

6036-006-105-B Existing Baghouse No.3............ . 3-3

4. JM Chemical Feed and Control systems Inc.

Ivyland, Pennsylvania

Process Flow and Instrumentation Drawings

Number

Title

D7ち-4604-PID Water Sample Panel 4A............. . 4-1

5. Fairfield Engineering Company

Marion, Ohio

Process Flow and Instrumentation Drawings

Number

Title

$\mathrm{E}-10-23691-6$

$E-10-23691-7$

Limestone Handling system General Arrangement . 5-1

Limestone Handling System General Arrangement . 5-2 
6. Lawrence Industries Limited Burlington, Ontario, Canada Process Flow and Instrumentation Drawings Number Tit.le

CB1851-005

Process Instrumentation Diagram for . . . . . . 6-1 Lubrication Oil system 
NUCLA CFB DEMONSTRATION PROJECT

\title{
PROJECT PUBLIC DESIGN REPORT
}

\author{
APPENDIX C \\ PROPRIETARY \\ PROCESS AND INSTRUMENTATION DRAWING \\ INDEX
}

(Bound Separately) 


\section{APPENDIX C PROPRIETARY \\ PROCESS AND INSTRUMENTATION DRAWING}

Section

Contents

Exhibit

Number

Number

1. Pyropower Corporation San Diego, California

Process Flow and Instrumentation Drawings

Number

001-06-5002

$001-06-5003$

$001-06-5004$

$001-06-5005$

$001-06-5006$

$001-06-5009$

$001-06-5012$

$001-06-5013$
Title

Process Flow Diagram . . . . . . . . . . . 1-1

Process Flow Tables . . . . . . . . . . . 1-2

Fuel, Limestone and Ash P\&I Diagram . . . . . . 1-3

Air and Flue Gas P\&I Diagram . . . . . . . . . 1-4

Steam/Water P\&I Diagram . . . . . . . . . . . 1-5 Coal Handling $P \& I$ Diagram . . . . . . . . . . . 1-6

Gas Start-Up Burner P\&I Diagram . . . . . . . . 1-7

Duct Burner P\&I Diagram . . . . . . . . . . 1-8 
NUCLA CFB DEMONSTRATION PROJE:T

PROJECT PUBLIC DESIGN REPORT

APPENDIX D

TECHNICAL ADVISORY GROUP

LIST OF ORGANIZATIONS 


\section{NUCLA CFB DEMONSTRATION PROJECT}

TECHNICAL ADVISORY GROUP

\section{Purpose}

The Technical Advisory Group (TAG) was formed to provide a forum whereby all participants in the Nucla CFB Demonstration Project may discuss the progress of the Project and provide comments to Colorado-Ute Electric Association, Inc., to assure the Project will provide maximum benefit for all participants.

The TAG will provide direction for the test program and may be called upon to assist with specific problems that arise during the construction, start-up and testing of the project.

\section{Membership}

Full membership of the TAG is open to all organizations that participate in the Nucla Project. Participants in the Project include Colorado-ute, equipment suppliers that share in the project risks and other organizations that make significant contributions to the project funding.

An Associate Membership may be obtained by those organizations that desire to obtain first hand information on the project but do not wish to contribute to the project funding. An Associate Membership will cost $\$ 50,000$. Associate Members will receive all bulletins and general information that full members receive. Associate Members may also attend the TAG meetings.

\section{Organization}

The TAG will be made up of one representative of each of the participants in the Nucla CFB Demonstration Pro: ct as outlined in the Membership section.

The representative from Colorado-ute will serve as Chairman of the TAG. Me ings will be held quarterly or as necessary lo deal with unusual ituations. Membership in Ad Hoc committees for direction or technical advisory functions will be limited to full members of the TAG. 
Full Membership

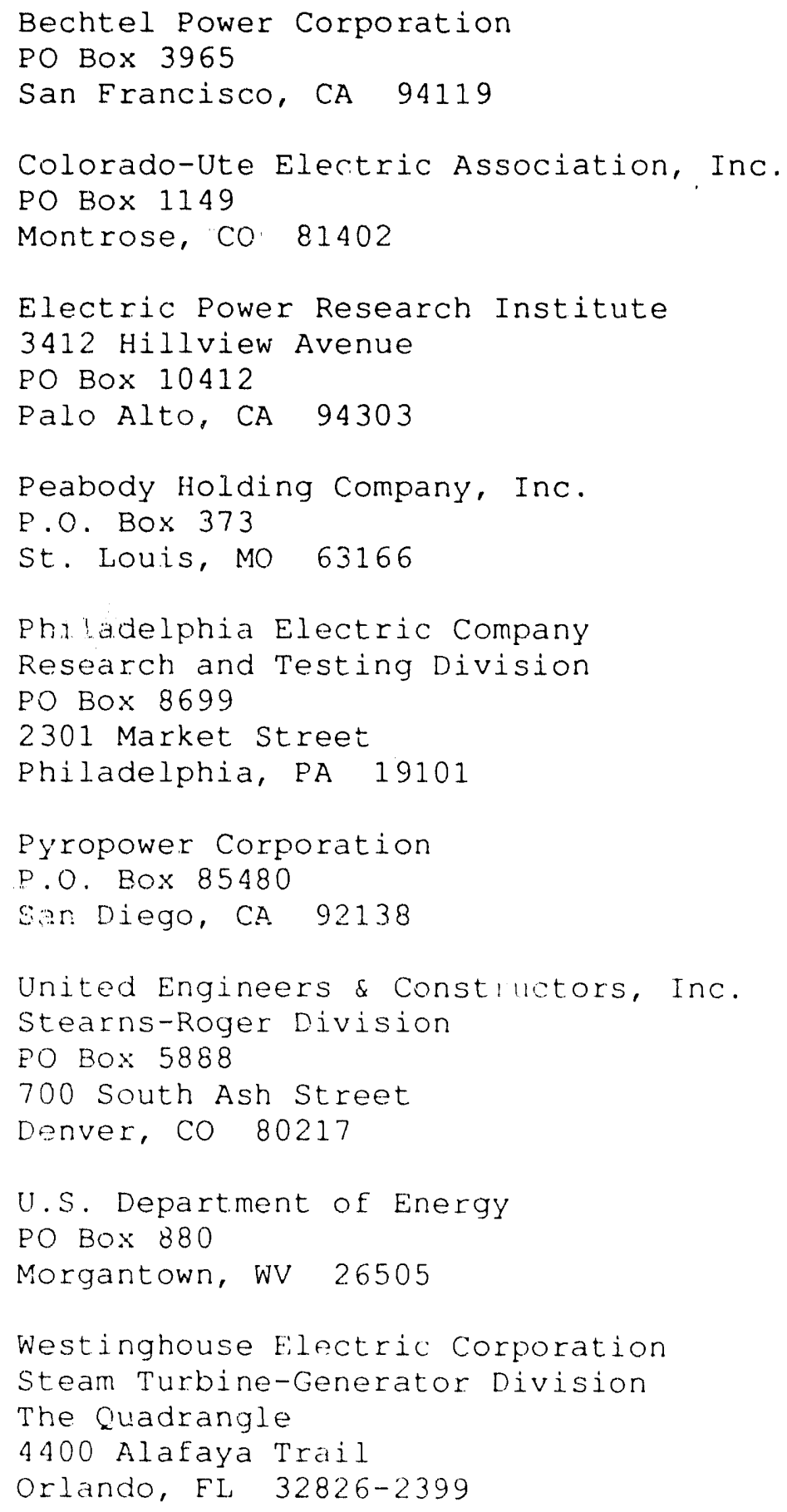


Associate Membership

AES Shady point, Inc.

PO Box 759

Panama, OK 74951

Consolidated Edison

Four Irving Place, Room 1428

New York, NY 10003

Department of Water \& Power of the

City of Los Angeles

111 North Hope Street, Room 129

P.O. Box 111, Terminal Annex

Los Angeles, CA 90051

General Electric Company

One River Road, Building 2, Room 2E

Schenectady, NY 12345

Houston Lighting \& Power Company

12301 Kurland Drive

Houston, TX 77034

Kerr-McGee Chemical Corporation

P.O. Box 25861

Oklahoma City, OK 73125

National Rural Electric Cooperative Assn. 1800 Massachusetts Avenue NW

Washington, DC 20036

National Rural Utilties Cooperative

Finance Corporation

1115 30th street NW

Washington, DC 2000 ?

Northeast Utilties Service Company

P.O. Box 270

Hartford, CT 06141-0270

Pacific Gas \& Electric

3400 Crow Canyon Road

San Ramon, CA 94583

Public Service Companv of Colorado

5909 liast 38 th Avenue

Denver, CO 80207 
Rural Electrification Administration

U.S. Department of Agriculture

$14 \mathrm{th}$ \& Independence Avenue SW, Room 0218-S

Washington, DC 20250-1500

Salt River Project

P.O. Box 52025

Phoenix, AZ 85072-2025

San Diego Gas and Electric

PO Box 1831

101 Ash Street

San Diego, CA 92124

Southern California Edison Company

PO Box 800

2244 Walnut Grove Avenue

Rosemead, CA 91.770

Tennessee Valley Authority

Division of Energy Demonstrations and Technology

3N 41A Missionary Ridge Place

1101 Market Street

Chattanooga, TN 37402-2801

Utah Power and Light

168 North 1950 west

Salt Lake City, UT 84104

Virginia Power

Innsbrook Technical Center

5000 Dominion Boulevard

Glen Allen, VA 23260 

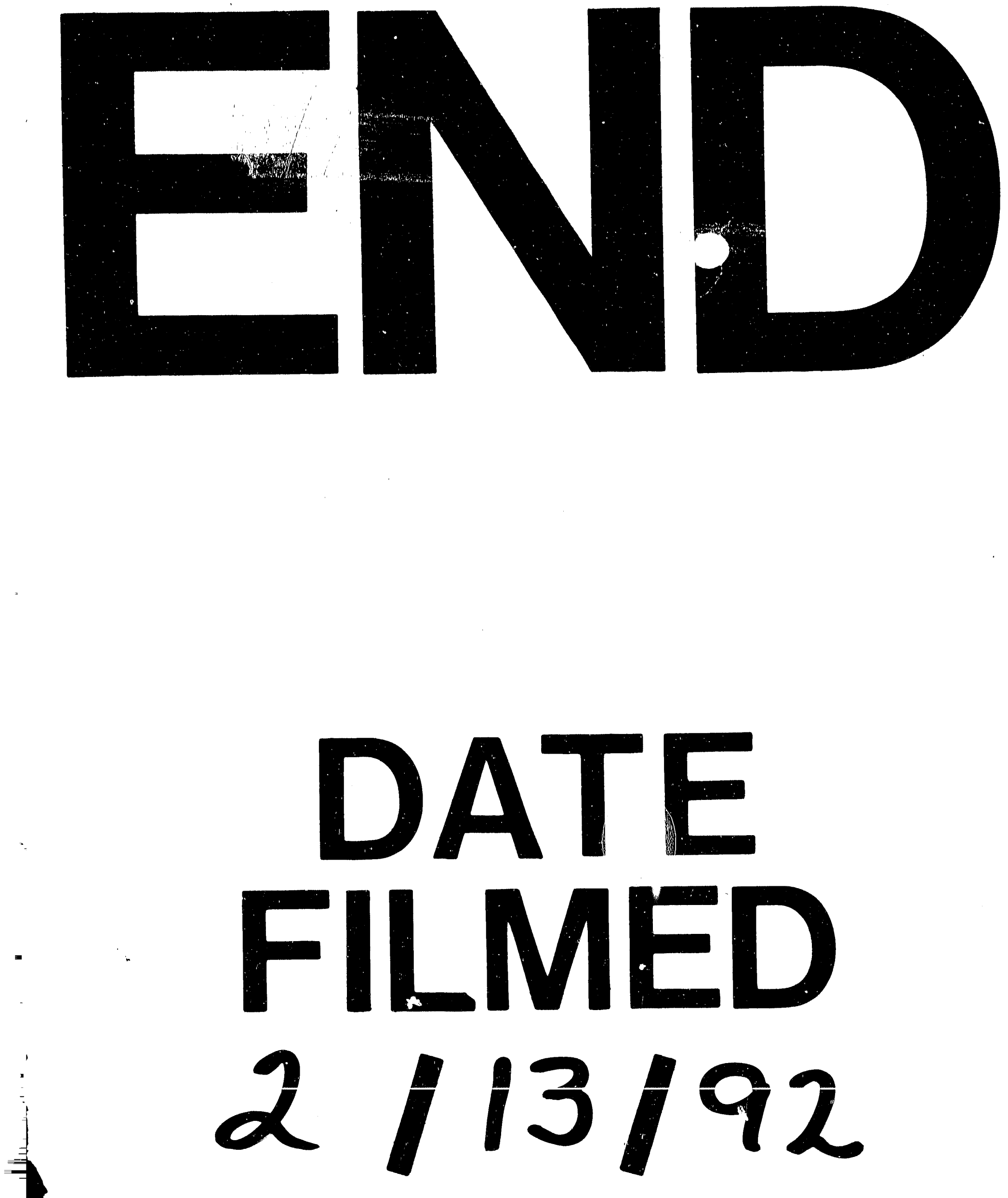